\title{
APLICAÇÃO DOS SISTEMAS DE INFORMAÇÃO GEOGRÁFICA (SIG) NO ESTUDO DA VIOLÊNCIA NO AMBIENTE URBANO: 0 CASO DO MUNICÍPIO DE SÃO PAULO-SP
}

MÍRIAM TORRIGO

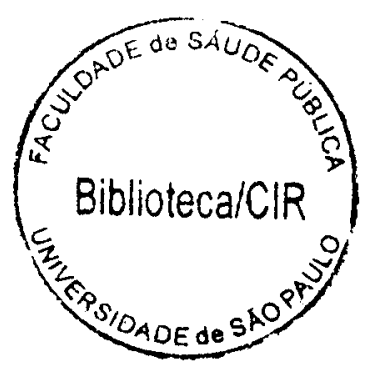

Dissertação apresentada na Área de Saúde Ambiental da Faculdade de Saúde Pública da Universidade de São Paulo para a obtenção do Grau de Mestre.

Área de Concentração: Saúde Ambiental

ORIENTADOR(A): PROF ${ }^{a}$. Dr ${ }^{a}$. HELENA RIBEIRO

São Paulo

2005 
Autorizo, exclusivamente para fins acadêmicos e científicos, a reprodução total ou parcial desta dissertação, por processos fotocopiadores.

Assinatura:

Data:

$$
46795 / 2005 \text { doc }
$$


A três grandes mulheres:

minhas avós Giovanna Stefan (in memorian) e Palmyra Marques Cruz (in memorian), e minha mãe Guerrina Kucich, pelo exemplo de perseverança e amor. 
"O senhor Palomar pensa no mundo sem ele: aquele inexistente de antes de seu nascimento, e aquele bem mais escuro de depois de sua morte; procura imaginar 0 mundo antes dos olhos, de qualquer olho; e o mundo que por uma catástrofe ou lenta corrosão se torne cego".

ITALO CALVINO 


\section{AGRADECIMENTOS}

Aos meus pais, Sérgio Torrigo, pelo exemplo de dedicação às causas ambientais, e Guerrina Kucick, pelo constante incentivo aos meus sonhos, o meu eterno amor.

À professora Dra. Helena Ribeiro, pela orientação prestada e pelo incentivo permanente, sem a qual não seria possivel a realização deste meu trabalho acadêmico, os meus sinceros agradecimentos.

Ao chefe e amigo, professor PhD. Örjan Olsén que possibilitou a concretização deste estudo, contribuindo com inúmeras sugestões e material bibliográfico, a minha completa admiração.

Ao amigo Gil Carlo Bindi, pelas discussões filosóficas e exemplo de ética acadêmica.

A Márcia Regina Lovatto Rostichelli, pelas conversas e apoio.

A Marcos Rogério Sanches, amigo e companheiro de trabalho, pelas aulas de estatística.

Aos professores Dr. Leandro Piquet Carneiro, Dr. José Luis Negrão Nucci e Dr. Jurandir Luciano Ross, pelas sugestões.

A Secretaria de Segurança Pública do Estado de São Paulo, na pessoa de Túlio Kahn; ao Centro de Estudos da Metrópole; ao IBGE e a Multispectral Ltda, pelo fornecimento dos dados necessários a construção deste trabalho.

Ao CNPQ (Conselho Nacional de Desenvolvimento Científico e Tecnológico), pela bolsa de estudos concedida. 


\section{RESUMO}

TORRIGO, MIRIAM. Aplicação dos Sistemas de Informação Geográfica (SIG) no estudo da violência no ambiente urbano: o caso do Município de São Paulo, 2005.

\section{Resumo}

A violência tem se tornado um problema internacional e nacional de saúde pública, que se manifesta mais intensamente nas grandes cidades. No Município de São Paulo, a violência se tornou a principal causa externa de óbitos e tem retardado o aumento da expectativa de vida de sua população. Visando contribuir para o melhor conhecimento da problemática, este estudo teve como objetivo principal: Mapear os principais tipos de crime que ocorrem no Município de São Paulo e que têm impactos diretos e indiretos sobre a saúde de sua população, utilizando-se metodologias da Geografia e técnicas de geoprocessamento. Metodologia: $O$ trabalho desenvolveu-se em duas escalas geográficas: a) o município de São Paulo, onde se trabalhou com cluster analysis e se mapeou zonas homogêneas de padrões de criminalidade; b) em quatro distritos policiais selecionados (Capão Redondo, Morumbi, Santo Amaro e Sé), onde se mapeou, com técnicas de pontos de contagem, o local de ocorrência dos seguintes tipos de crime: estupros, homicídios, tentativas de homicídio, latrocínios, roubo a residências, roubo a transeuntes, roubo de veículos e roubo a interior de veículos. Os dados utilizados foram mais de 3 milhões de boletins de ocorrência, do período de janeiro de 2001 a março de 2004, do INFOCRIM da Secretaria de Segurança Pública do Estado de São Paulo. Resultados: Constatou-se grande diferença entre a incidência dos variados tipos de crime em áreas intra-urbanas. Em algumas, como Capão Redondo há maior incidência de crimes contra a pessoa, no Morumbi destacam-se os crimes contra o patrimônio (roubo a residências, veículos e interior de veículos), no Distrito Policial de Santo Amaro destacaram-se os roubos a transeuntes, de veículos e a interior de veículos, na Sé os roubos a transeuntes, estupros e homicídios. Os padrões de distribuição dos crimes no interior de cada distrito também variou, dependendo do distrito. Conclusões: Não há uma similaridade/homogeneidade na distribuição dos diferentes tipos de crime no Município de São Paulo. A Geografia e as técnicas de geoprocessamento mostraram-se muito úteis para auxiliar na formulação de políticas de prevenção e vigilância na área da segurança pública. 


\title{
SUMMARY
}

TORRIGO, MIRIAM. Application of Geographic Information System (GIS) to the study of violence in urban environment: the case of the Municipality of São Paulo, 2005.

\begin{abstract}
Violence nowadays is an international and national public health problem, particularly intensive in large cities. In the Municipality of São Paulo, violence became the main external cause of deaths and has been retarding increases in life expectancy. Aiming to contribute to better knowledge of this problem, this study had as main objective: To map the main types of crimes that occur in the Municipality of São Paulo and that present health impacts on the population, using methods proper to Geography and Geographical Information System techniques. Methods: The work was developed in two geographical scales: a) the municipality of São Paulo, where cluster analysis was used and homogeneous crime areas were mapped; $b$ ) in four selected police districts (Capão Redondo, Morumbi, Santo Amaro e Sé), where the address of the following types of crimes were mapped, using dots as cartographical technique: rapes, murders, tentative murders, robbery followed by murder, robbery to houses, robbery to pedestrians, robbery of cars and robbery to inside of cars. Data utilized were more than 3 millions crime bulletins, from the period January 2001 to March 2004, from INFOCRIM of Secretaria de Segurança Pública do Estado de São Paulo. Results: A large difference between the incidence of various crimes within intra-urban areas was verified. In some districts, as Capão Redondo there is greater incidence of crimes against persons, in Morumbi crimes against property (robbery to residences, vehicles and inside vehicles), in Santo Amaro were more frequent robberies to pedestrians, of cars and inside cars, in Sé district robberies to pedestrians, rapes and murders. The pattern of distribution of crimes inside each district also varied, depending on the district characteristics. Conclusions: There is no similarity in the distribution of different crimes in the Municipality of São Paulo. Geography and Geographical Information Systems revealed to be of large importance to help the formulation of prevention and surveillance public security policies.
\end{abstract}




\section{ÍNDICE}

1 INTRODUÇÃO

2 JUSTIFICATIVA

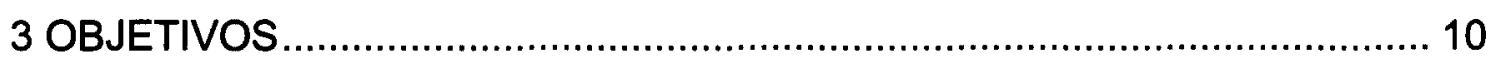

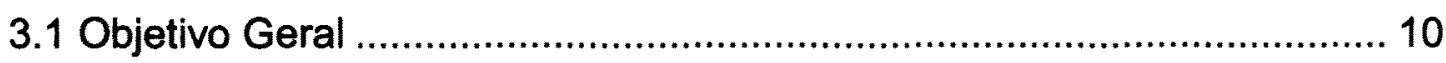

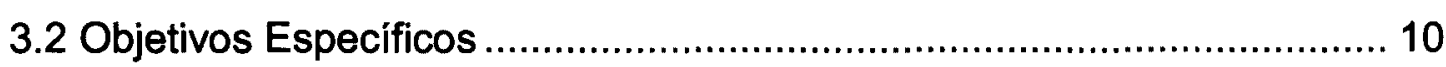

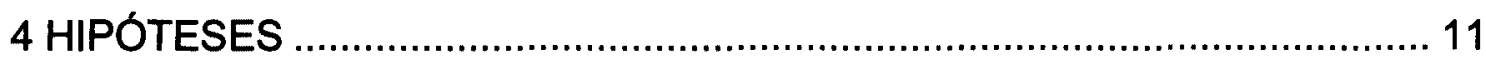

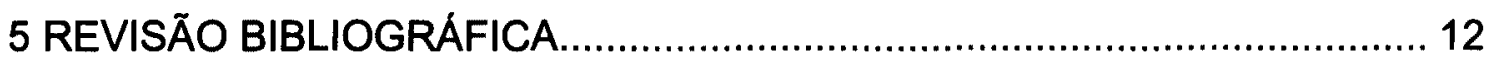

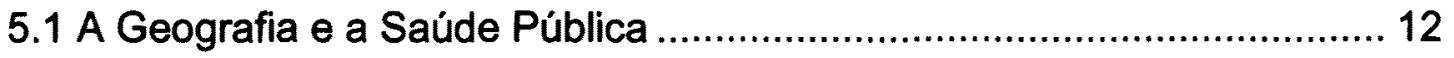

5.2 Sistemas de Informação Geográfica (SIG) ............................................ 22

5.2.1 Evolução dos Sistemas de Informação Geográfica (SIG)................. 23

5.2.2 Geoprocessamento e Sistemas de Informação Geográfica (SIG) .... 25

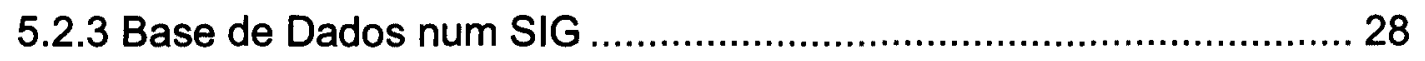

5.2.4 Conexão Entre Dados Gráficos e Não-Gráficos .............................. 30

5.2.5 Base de Dados Não-Gráficos (Alfanuméricos) ................................ 31

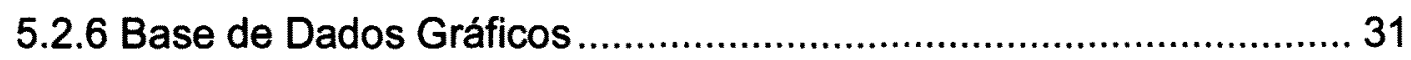

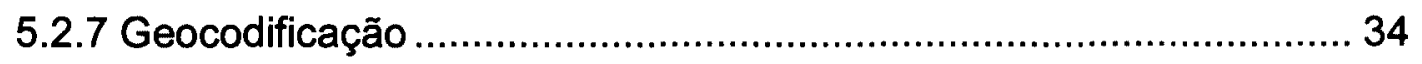

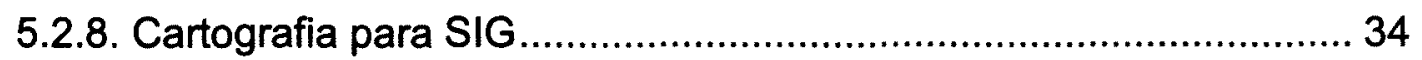

5.2.9 Tratamento de Dados em um SIG .................................................. 36

5.2.10 O Papel dos SIG na Análise Criminal ........................................... 43

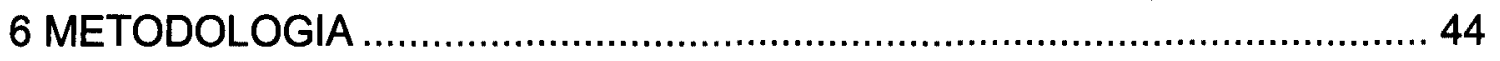

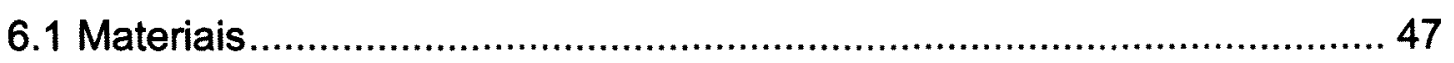

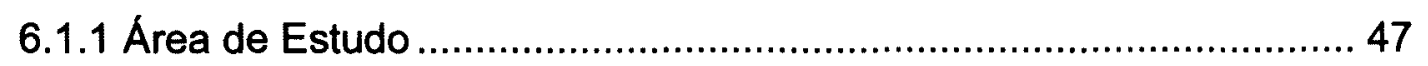

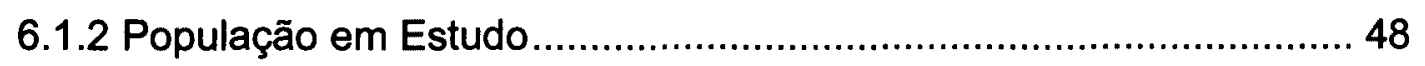

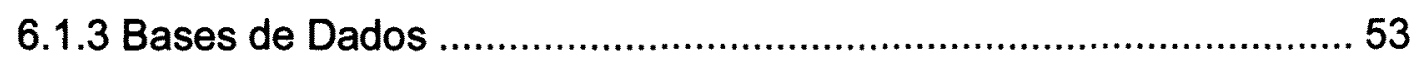

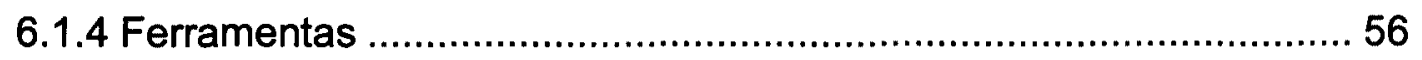

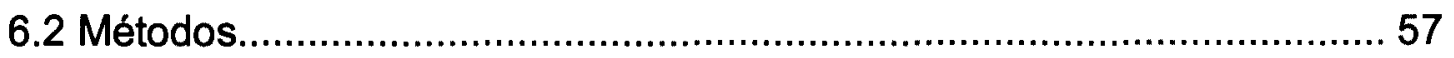

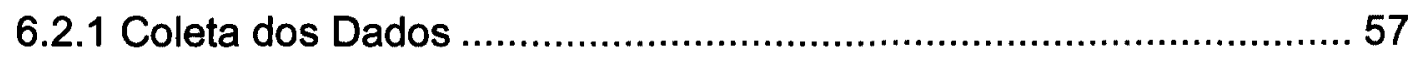




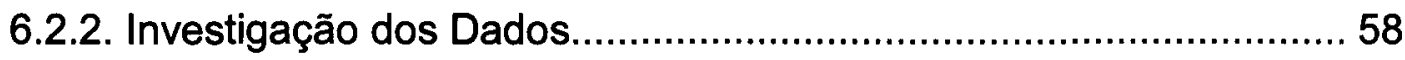

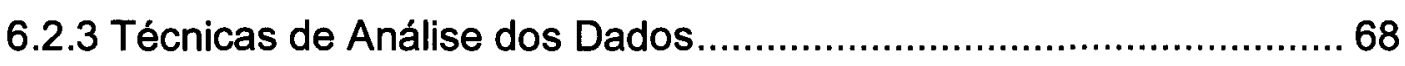

6.2.4 Processamento dos Dados............................................................ 73

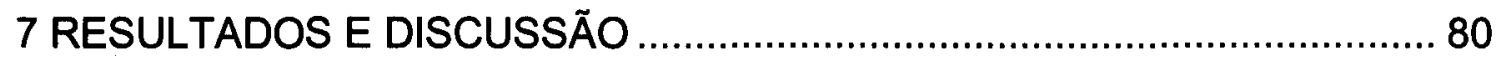

7.1 Distribuição Espacial de Variáveis Sócio-Econômicas no Município de

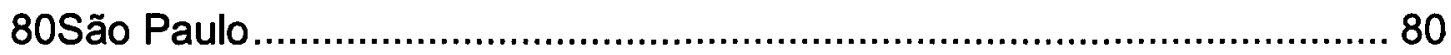

7.2 Distribuição Espacial do Crime pela Unidade dos Distritos Policiais (DP)82

7.3 Distribuição espacial do crime "por ponto" na escala do Distrito Policial. 91

7.3.1 Crimes Contra a Pessoa............................................................... 92

7.3.2 Crimes Contra os Costumes ..................................................... 108

7.3.3 Crime contra o Patrimônio ........................................................... 116

8 CONSIDERAÇÕES FINAIS E RECOMENDAÇÕES …............................. 139

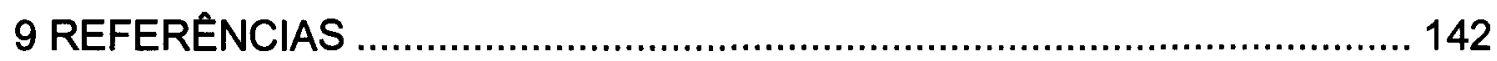




\section{LISTA DE FIGURAS}

Figura 1 - Esquema representativo da integração de técnicas. 26

Figura 2 - Estratégia dual para bancos de dados geográficos. 30

Figura 3 - Representações vetoriais: ponto, arco, nó e polígono. 33

Figura 4 - Exemplo de desatualização de eixo de logradouros. 36

Figura 5 - Representação vetorial e matricial de um mapa temático. $\quad 38$

Figura 6 - Exemplo de mapa cadastral, mostrando alguns países da América do Sul com seus respectivos atributos descritivos. 39

Figura 7 - "Clusters sócio-econômicos" por setor censitário.

Figura 8 - Agrupamentos homogêneos de distritos policiais. 84

Figura 9 - Agrupamentos homogêneos de distritos policiais com favelas. 87

Figura 10 - Agrupamentos distritos policiais com vias principais. $\quad 88$

Figura 11 - Agrupamentos distritos policiais com rede transporte. $\quad 89$

Figura 12 - Homicídio - Capão Redondo. 95

Figura 13 - Tentativa de Homicídio - Capão Redondo. 96

Figura 14 - Tentativa e Homicídio - Capão Redondo. 97

Figura 15 - Homicídio - Morumbi. 98

Figura 16 - Tentativa de Homicído - Morumbi. 99

Figura 17: Latrocínio - Morumbi. 100

Figura 18 - Homicídio - Santo Amaro. 101

Figura 19 - Tentativa de Homicídio - Santo Amaro. 102

Figura 20 - Latrocínio - Santo Amaro. 103

Figura 21 - Homicídio - Sé. $\quad 104$

Figura 22 - Tentativa de Homicídio - Sé. 105

Figura 23 - Latrocínio - Sé. $\quad 106$

Figura 24 - Estupro - Capão Redondo. 111

Figura 25 - Estupro - Morumbi. 112

Figura 26 - Estupro - Santo Amaro. 113

Figura 27 - Estupro - Sé. $\quad 114$ 
Figura 28 - Roubo à Residência - Capão Redondo.

Figura 29 - Roubo à Residência - Morumbi.

Figura 30 - Roubo à Residência - Santo Amaro.

Figura 31 - Roubo à Residência - Sé.

Figura 32 - Roubo a Transeunte - Capão Redondo.

124

Figura 33 - Roubo a Transeunte - Morumbi.

Figura 34 - Roubo a Transeunte - Santo Amaro.

126

Figura 35 - Roubo a Transeunte - Sé.

Figura 36 - Roubo de Veículo - Capão Redondo.

129

Figura 37 - Roubo a Interior de Veículo - Capão Redondo.

130

Figura 38 - Roubo de Veículo - Morumbi.

131

Figura 39 - Roubo a Interior de Veículo - Morumbi.

132

Figura 40 - Roubo de Veículo - Santo Amaro.

133

Figura 41 - Roubo a Interior de Veículo - Santo Amaro

Figura 42 - Roubo de Veículo - Sé.

Figura 43 - Roubo a Interior de Veículo - Sé. 


\section{LISTA DE QUADROS}

Quadro 1 - Comparação Entre Formatos para Mapas Temáticos.

Quadro 2 - Vantagens e desvantagens da Grade Triangular e Regular para a Representação de MNT.

Quadro 3 - Principais Características das Bases de Dados

alfanuméricos.

Quadro 4 - Principais Características das Bases de Dados Gráficos. $\quad 55$

Quadro 5 - Registros por ano.

59

Quadro 6 - Número de Ocorrências por Natureza.

61

Quadro 7 - Gráfico hipotético de dispersão.

Quadro 8 - Distribuição dos óbitos por agressões segundo o dia da semana. Estado de São Paulo - 2001. 


\section{LISTA DE TABELAS}

Tabela 1- Variáveis censitárias por grupos homogêneos.

65

Tabela 2 - Dados hipotéticos para ilustrar a análise de agrupamentos.

Tabela 3 - Pesos dos diversos crimes para dois DP's na cidade de São Paulo.

Tabela 4 - Características dos agrupamentos homogêneos de DP's em São Paulo. 


\section{LISTA DE ABREVIATURAS E SIGLAS}

IBGE:Instituto Brasileiro de Geografia e Estatística.

CEM: Centro de Estudo da Metrópole.

SSP-SP: Secretaria de Segurança Pública do Estado de São Paulo

SIG: Sistemas de Informação Geográfica.

GIS: Geographical Information Systems

CEBRAP: Centro Brasileiro de Análise e Planejamento.

CAD: Computer Aided Design

SPSS: Statistical Package for the Social Sciences

OMS: Organização Mundial da Saúde

SGBD: Sistema Gerenciados de Banco de Dados

WHO: World Health Organization

INPE: Instituto Nacional de Pesquisas Espaciais

PMSP: Prefeitura do Município de São Paulo

BO: Boletim de Ocorrência 


\section{INTRODUÇÃO}

O crescimento acelerado das metrópoles em paises não desenvolvidos acentuou e tornou mais perceptivel uma série de desequilibrios, principalmente entre procura $e$ oferta de habitações e serviços urbanos, que compõem uma problemática urbana especifica. (SINGER 1998, p.121)

O crescimento acelerado das metrópoles trouxe em seu bojo o expressivo aumento da violência. A violência foi definida, em 1981, pela Organização Mundial da Saúde como a imposição de um grau significativo de dor e sofrimento, evitáveis (CAMPOS, SCHOR, ANJOS et al., 2005). Sobretudo nas últimas décadas, quando ao crescimento demográfico se aliou uma forte crise econômica e social, a criminalidade passou a ser um problema de saúde pública. Altos índices de desemprego e concentração de renda e baixos niveis de rendimento do trabalho, somados às ineficiências da polícia e da justiça contribuiriam para o agravamento e crescimento da criminalidade no país e na cidade de São Paulo. Assim, a violência e a criminalidade se tornaram fenômenos sociais que vêm motivando estudos acadêmicos.

A mobilidade da população das áreas rurais para as urbanas, particularmente para os grandes centros, intensificou-se de forma acentuada a partir da década de 1960. As consequeências deste fato têm sido extremamente desfavoráveis, visto que as condições de moradia, sob todos os aspectos, são as piores possiveis, geralmente nas áreas periféricas das grandes cidades (JORGE E GOTLIEB, 2000).

De acordo com Singer (1998), o crescimento urbano agravou a insuficiência dos serviços urbanos básicos, como o abastecimento de água encanada e de esgotos, de leitos hospitalares, etc. Além disso, houve um aumento contínuo do desemprego, da delinqüência, e conseqüentemente dos problemas de segurança pública. 
Segundo os resultados apresentados pela Pesquisa Nacional de Saneamento Básico de 2000 (IBGE, 2002), houve uma pequena melhoria, para a década de 1990, nos serviços de saneamento, que passaram a abranger uma parcela maior da população brasileira. Por outro lado, ainda se observa nas periferias das grandes cidades, uma segregação no acesso a determinados serviços de infra-estrutura, e meios de consumo coletivo, ou seja, um déficit no crescimento dos serviços públicos em relação ao crescimento populacional.

Langenbuch (Mimeo) também nos remete à questão do crescimento urbano e suas repercussões:

O crescimento metropolitano repercute de modo muito intenso sobre os arredores, onde uma série de núcleos suburbanos preexistentes vê as respectivas áreas edificadas fundirem-se entre si e com São Paulo, enquanto núcleos mais afastados crescem e, desenvolvem-se novos a maiores distâncias.( p.20)

Desta forma, o município de São Paulo, estudo de caso deste trabalho, tem seu processo de reprodução do espaço urbano inter-relacionado ao processo de reprodução espacial da metrópole paulista que, ao se desenvolver, amplia seus limites territoriais formando uma mancha urbana (não necessariamente contínua). Esta mancha, apesar de ser concentrada, apresenta tendência a espalhar-se, através da incorporação de novos espaços e da transformação e reestruturação de outros já ocupados.

Tal crescimento também expressa diferenças quanto ao uso do solo urbano, conforme citam Lefebvre e Carlos:

Entretanto, mesmo onde a separação dos grupos sociais não aparece como uma evidência gritante no terreno há uma pressão nesse sentido e traços de segregação aparecem. $O$ caso-limite, o resultado último, é o gueto. Observamos que há muitos guetos e tipos de gueto: 
aqueles dos Jardins, e dos negros; mas também os intelectuais têm, à sua maneira, guetos; as pessoas de altas rendas também se isolam em guetos de riqueza. 0 lazer tem seus guetos. Lá onde uma ação harmonizada tentou fundir as camadas sociais e as classes, uma separação espontânea rapidamente ocorre (LEFEBVRE 1968, p.99).

A paisagem ${ }^{1}$ urbana metropolitana refletirá assim, a segregação espacial ${ }^{2}$. Tal segregação aparece no acesso a determinados serviços de infraestrutura, aos meios de consumo coletivo. (CARLOS 1994, p.55)

Assim, torna-se importante o conhecimento destas diferenciações como meio de se pensar soluções ou formas de atenuação destes efeitos sobre a sociedade como um todo.

Conforme evidenciam Mc Dowell e Newel (1997) citados por Costa (2001), a avaliação do nivel de vida de populações humanas é, há bastante tempo, assunto de interesse de organismos governamentais e nãogovernamentais, em âmbito nacional e internacional. Por mais de cem anos, a maioria dos países ocidentais vem coletando dados estatísticos relativos às condições sociais de suas populações.

Esta demanda por informações que propiciem o gerenciamento da qualidade de vida, em especial no que se refere à saúde das populações, vem sendo gerada na busca por políticas sustentáveis para satisfazer as necessidades atuais das populações e para preservar o meio ambiente.

Com efeito, tem-se procurado identificar as interfaces de problemas que se originam em diferentes setores, para a elaboração de novos tipos de

\footnotetext{
${ }^{1}$ A paisagem é a manifestação formal do processo de produção do espaço colocando-se no nivel do aparente e imediato (CARLOS 1994).

${ }^{2}$ Ao produzir sua vida (sua história, a realidade) a sociedade produz, concomitantemente, o espaço geográfico. Ele é o produto das relações fundamentadas na divisão do trabalho que ocorrem num determinado momento histórico entre os homens e a natureza (CARLOS 1994).
} 
informações que demonstrem, de maneira explícita, a relação entre o desenvolvimento econômico e a degradação das condições de saúde, em função da degradação das condições ambientais (FUNASA, 2001).

A paisagem não é fruto de uma mera soma de elementos homogêneos, mas de uma interdependência de fatores heterogêneos e contraditórios que se integram no processo espacial. Assim, Laurenti et al., afirmam que:

A Organização das Nações Unidas, por meio de seu Conselho Econômico e Social, formou um Comitê, no início da década de 50, que teve como incumbência a elaboração de um informe sobre os métodos mais satisfatórios para se medir e avaliar o nível de vida de uma população. Dada a complexidade do assunto, o comitê sugeriu que o problema da mensuração de niveis de vida fosse abordado de maneira pluralista, se considerando vários componentes passiveis de quantificação. (LAURENTI et al. 1985, p.161),

Portanto, fica evidente, conforme relatado pelos autores citados, que o processo de urbanização crescente traz repercussões negativas à qualidade de vida das populações, e que uma tentativa na busca por soluções, ou pela diminuição destas "irregularidades", deve perpassar pela idéia de sociedade como algo multifacetado e dinâmico.

Novas problemáticas interdisciplinares ${ }^{3}$ infundem novas exigências de produção do conhecimento e sua aplicação no planejamento do desenvolvimento. A articulação entre os conhecimentos corresponde ao fundamento primeiro de um desenvolvimento científico capaz de responder aos problemas multidimensionais da sustentabilidade do desenvolvimento.

Uma das importantes alterações que vêm ocorrendo, em decorrência do processo de urbanização acima descrito, é uma mudança no perfil brasileiro de

\footnotetext{
${ }^{3}$ Entende-se por interdisciplinar, o encontro de duas ou mais disciplinas, trazendo cada uma delas (no plano da teoria e pesquisa científica) seus próprios esquemas conceituais, sua forma de definir os problemas e seus métodos de investigação.
} 
causas de morte. Houve um crescimento relativo e absoluto da mortalidade por acidentes e violências. Enquanto no final da década de 1970 os acidentes e violências foram responsáveis por 60.000 óbitos, constituindo a quarta causa de morte, no final dos anos 1980 já constituíam a segunda causa de morte, com mais de 100.000 óbitos no país (CAMARGO, ORTIZ E FONSECA, 2000). Dentro das mortes violentas, o crescimento do número de homicídios destacase, sobretudo entre a população masculina brasileira em idade ativa.

Entretanto, o aumento da criminalidade não é um fenômeno exclusivo do Brasil, nem está restrito aos países em desenvolvimento. Segundo CarreraFernandez e Pereira (2002), é um fenômeno generalizado que se estende a todos países e que tem alcançado dimensões internacionais sem precedentes.

O avanço da criminalidade no Estado de São Paulo vem sendo sentido desde os meados dos anos 1960. No entanto, nos últimos anos tem sido constatado um aumento vertiginoso não apenas da violência urbana, mas principalmente do número de ocorrências policiais registradas... (CARRERA-FERNANDEZ e PEREIRA 2002, p. 195)

Ainda segundo Carrera-Fernandez e Pereira (2002), os volumes de recursos diretamente envolvidos nas ocorrências de crimes no Estado de São Paulo representam cerca de $5 \%$ do seu PIB. Esse valor só inclui gastos públicos com policiamento e equipamentos de prevenção ao crime, mas não inclui gastos hospitalares com as vítimas e os custos com segurança privada. Três correntes de pensamento econômico explicariam o fenômeno: A primeira, que elege fatores psicológicos e sociológicos como elementos importantes para formação do criminoso; a segunda defende que o comportamento criminoso está ligado às características do processo capitalista, resultante de alterações do capital empresarial que se torna mais centralizador e, conjuntamente com os avanços tecnológicos resultantes, formam ambientes sociais propensos às 
atividades criminosas; a terceira corrente vê o criminoso como um agente econômico, que responde a incentivos econômicos do crime.

Tendo como pilar a idéia de que o real é dinâmico e complexo e que a realidade apresenta uma lógica que a constitui, o presente trabalho demonstrará apenas uma visão da atual problemática de saúde do municipio.

O produto final se dará a partir da integração de dados quantitativos que melhor descrevam os aspectos da violência que possam afetar a saúde da população local.

Deste modo, levando-se em conta as ressalvas quanto à geração e o uso indiscriminado da informação quantitativa, este estudo buscará, através da aplicação dos Sistemas de Informação Geográfica, elaborar um ensaio que contribua para a organização de um diagnóstico da violência no município de São Paulo, a partir da representação espacial do crime por duas escalas de análise. A primeira etapa se dará na escala do municipio, através da representação espacial de variáveis censitárias e de bases de dados de natureza de ocorrências criminais para o período de janeiro de 2001 a agosto de 2003. E a segunda etapa abordará, na escala do distrito policial, a distribuição pontual de boletins de ocorrências, no periodo de abril de 2003 a março de 2004.

Os Sistemas de Informação Geográfica apresentam grande valia no auxilio à descrição do nivel de qualidade de vida de uma população e no monitoramento de seus problemas sociais; pois permitem a concretização de uma visão interdisciplinar, devido à existência de ferramentas acessiveis de manipulação da informação, que integram dados de diferentes fontes e formatos, de forma dinâmica.

Em suma, a deterioração das condições de vida e trabalho, a degradação do meio ambiente e a apropriação desigual dos direitos, bens e riquezas produzidos pela sociedade, entre muitos outros males, estão na raiz da produção social das doenças, do sofrimento mental e da morte prematura. 
Dentro deste quadro, o presente trabalho terá repercussão direta no auxílio a órgãos municipais no gerenciamento de questões de saúde relacionadas à violência. 


\section{JUSTIFICATIVA}

A adaptabilidade de nossa espécie à vida em um mundo cada vez mais urbano deveria de fato ser um tópico de pesquisa(...) As multidões e a vida agitada das cidades requerem complexos ajustes comportamentais e culturais que, a longo prazo, possuem uma grande importância para a nossa vida como animais sociais e criadores de símbolos e significados. (MORAN 1994, p. 381).

A Geografia da Saúde se propõe a tratar temas situados em fronteiras do conhecimento. No caso de nosso estudo, são situações de violência urbana que se constituem em grave problema de saúde pública atualmente (MINISTÉRIO DA SAÚDE, 2004). Tal problema vem sendo estudado e discutido por diversos profissionais, de diferentes áreas de pesquisa e atuação, com vistas a seu enfrentamento. $O$ que este trabalho traz é a contribuição da Geografia, ou seja, a aplicação de métodos e técnicas geográficas a um problema específico de saúde pública, de modo a contribuir para o entendimento das variáveis espaciais ou fatores do ambiente que possam apresentar relações de causalidade (MC GLASHAN, 1980). Em que pese o fato dos problemas de saúde pública serem multi-causais, alguma forma de seleção é necessária para sua abordagem. No caso, foi adotada a abordagem analítica das variações especiais.

O mapa é certamente um dos principais instrumentos da interpretação geográfica, uma vez que pode ser lido, usado e fomentar ações de outros profissionais (MC GLASHAN, 1980). Para tanto, é preciso que eles reflitam com acuidade os dados. Ou seja, os mapas não são simples figuras ilustrativas e sim representações georreferenciadas de dados coletados cuidadosamente em campo, padronizados e tratados por técnicas estatísticas consagradas. 
Entretanto, segundo MC Glashan (1980, p. 14) seria impróprio defender que a geografia provê prova, ela indica fatores para análises mais aprofundadas. Em todo o mundo, o setor saúde tem se conscientizado e verificado as potencialidades deste tipo de estudo em um contexto de crescentes custos com o sistema de saúde e da necessidade de racionalização de gastos e de ampliação dos resultados positivos (administração adequada e racional de recursos escassos).

Nas perspectivas acima elencadas, esta dissertação se propõe a contribuir ao diagnóstico da violência na cidade de São Paulo, com base em dados do período de janeiro de 2001 a março de 2004.

A maior parte dos estudos realizados sobre violência urbana, no Brasil e em São Paulo, tem se concentrado na mortalidade por agressão (homicídios). Tal fato se justifica devido às mortes violentas, ao longo das ultimas décadas, virem assumindo proporções cada vez maiores, embora este não seja um fenômeno exclusivo da sociedade brasileira. Alguns dos trabalhos têm mostrado que este fenômeno vem provocando um retardo no aumento da esperança de vida da população (FERREIRA e CASTIÑEIRA, 1966; CAMARGO et al., 2000). Na grande maioria dos estudos, se discute a questão da violência urbana, que melhor se expressa nas regiões metropolitanas, e se aponta como principal vítima a população que vive nas periferias destas cidades, carente de infra-estrutura urbana básica e de serviços públicos essenciais dos setores de saúde, educação e segurança.

Em nossa pesquisa, nos propomos verificar a distribuição espacial também de outros delitos / crimes que apresentam grande porcentagem de ocorrência.

Com efeito, compreender a distribuição espacial de dados oriundos de fenômenos ocorridos no espaço constitui hoje um grande desafio para a elucidação de questões centrais em diversas áreas do conhecimento, seja em saúde, em ambiente, em segurança pública, entre tantas outras. 


\section{OBJETIVOS}

\subsection{Objetivo Geral}

O presente trabalho tem como objetivo geral a elaboração de um estudo sobre a territorialidade das ocorrências criminais no município de São Paulo, através da aplicação de ferramentas disponíveis nos Sistemas de Informação Geográfica (SIG).

Este estudo se dará em duas escalas geográficas:

a) Na escala do município, através da representação espacial de variáveis censitárias e de bases de dados de natureza de ocorrências criminais, que descrevem, quantitativamente, o quadro de criminalidade do municipio de São Paulo, no período de janeiro de 2001 a agosto de 2003.

b) Na escala do distrito policial, através da distribuição pontual de boletins de ocorrências, no período de abril de 2003 a março de 2004.

\subsection{Objetivos Específicos}

- Testar a aplicação dos Sistemas de Informação Geográfica na representação espacial de bases de dados criminais;

- Fornecer informações para subsidiar políticas públicas de controle da criminalidade na cidade;

- Contribuir para a compreensão da violência urbana. 


\section{HIPÓTESES}

- Os Sistemas de Informação Geográfica são instrumentos úteis no entendimento e na gestão da violência urbana, na medida em que permitem, de forma rápida e localizada no território, a manipulação e tratamento de grandes volumes de dados, de diferentes fontes $e$ categorias de análise.

- Não há uma homogeneidade/similaridade na distribuição espacial dos diferentes tipos de crimes no município. Os Sistemas de Informação Geográfica, permitindo uma abordagem "multi-escalar", propiciam a visualização desses diferenciais intra-urbanos. 


\section{REVISÃO BIBLIOGRÁFICA}

Na medida em que o conceito de território ou de espaço transcende a sua condição fisica ou natural e recupera o seu caráter histórico e social, o estudo das condições de vida, segundo a inserção espacial dos grupos humanos no território, tende a ser uma alternativa teóricometodológica para a análise das necessidades e das desigualdades sociais da saúde. (PAIM 1997, p.11).

\subsection{A Geografia e a Saúde Pública}

Ao longo da história humana, os maiores problemas de saúde que os homens enfrentaram sempre estiveram relacionados com a natureza da vida em comunidade. Por exemplo: o controle das doenças transmissiveis, a assistência médica e a melhoria do ambiente físico através do saneamento.

Segundo Rosen (1994), as atividades ligadas à saúde comunitária podem ser encontradas nas mais antigas civilizações. Os indianos há cerca de 4 mil anos, dispunham de banheiros e sistema coletores de esgoto em suas cidades planejadas. Os Egípcios do Médio Império (2100-1700 a. C.) tiveram o cuidado de fazer a água escoar por calhas de pedra entre as ruas de suas cidades. Os quéchuas apresentavam um sistema de engenharia sanitária avançado para a época, além de reconhecerem uma conexão entre clima e saúde.

Ao lado das teorias litúrgicas das doenças, se desenvolveu, aos poucos, a idéia de a pestilência estar ligada a causas naturais, em especial, ao clima e ao ambiente físico.

De acordo com Rosen (1994), os gregos desenvolveram concepções naturalistas acerca da doença, atribuíram saúde e doença à natureza. Para eles a falta de saúde teria origem na desarmonia entre homem e ambiente. 
O primeiro esforço sistemático para apresentar as relações causais entre os fatores do meio físico e as doenças, foi apresentado na obra "Ares, Águas e Lugares", escrito por Hipócrates por volta de 480 a.C.

Hipócrates, segundo Rosen (1994), apresenta fatores para a endemicidade local como: o clima, o solo, a água, a nutrição e o modo de vida; além de reconhecer a presença contínua de certas doenças na população, que denominou "endêmicas", e de outras que apareciam com maior freqüência em determinadas épocas ou condições, para as quais atribuiu o nome de "epidêmicas".

Paraguassu-Chaves (2000) aponta, em síntese, quatro pontos principais na obra de Hipócrates:

Orientação: a constituição dos homens estaria condicionada pela exposição aos distintos pontos cardeais das cidades;

- Natureza das águas: traria conjuntos de seus efeitos benéficos ou danosos;

- Influência das estações: condicionariam as doenças; exemplo: afecções broncopulmonares no inverno, predomínio de infecções intestinais no verão, e;

- Influência da latitude geográfica: implícita na variedade climática que determinaria as diferenças psíquicas e somáticas, no gênero humano.

Para Andrade (2000), no cerne da análise de Hipócrates residia a relação entre o homem e o meio que, embora de forma determinista ${ }^{4}$, pode ser considerada uma análise geográfica.

Assim pode-se dizer que a origem do conhecimento geográfico, que se tornou cientifico em fins do século $X I X$, encontrava-se em alguns dos seus aspectos, na obra de Hipócrates.

\footnotetext{
4 "A ciência é determinista" na medida em que busca uma ordem, uma regularidade, um encadeamento entre os fenômenos, uma forma mesmo que complexa de causalidade, sem a qual o conhecimento científico não seria possível.
} 
Segundo Pessoa (1960), "Ares, Águas e Lugares" foi o primeiro tratado de Geografia Médica ${ }^{5}$ produzido, um dos mais importantes legados da Antiguidade Clássica que seguiu como referência até o final do século XIX, quando as novas ciências da Bacteriologia e da Imunologia se instituíram.

A linha de raciocínio desenvolvida por Hipócrates se revitalizou em fins do século XVII com o "neohipocratismo", dando lugar a um gênero que teria grande difusão, as "Topografias Médicas" (URTEAGA, 1980).

O enfoque determinista, dominante na literatura higienista ${ }^{6}$, durante grande parte do século $X I X$, foi também o substrato teórico das Topografias Médicas ${ }^{7}$.

De acordo com Urteaga (1980), as Topografias Médicas apresentavam uma sistemática preocupação com o meio e as suas possibilidades de relação com as patologias, indicando áreas salubres e insalubres para habitação, numa escala local.

No Brasil, segundo Pessoa (1960) os primeiros relatos, neste ramo da medicina que estudava as interações do homem com o ambiente, foram feitos por viajantes que descreviam numerosas moléstias, ou davam sua distribuição geográfica, como Lery, Thevet, S. Hilaire, Spix e Martius, Koster e outros.

Como não se conhecia a etiologia nem a transmissão das doenças infecciosas reinantes, a maioria dos autores fazia de suas pesquisas, um inventário climático e fitogeográfico.

Com o surgimento da Geografia enquanto ciência, em meados do século $\mathrm{XIX}$, estes estudos passam a ter um enfoque local e não mais global. Os elementos da Geografia Física são justificados como os causadores das doenças.

\footnotetext{
${ }^{5}$ Neste período, os trabalhos de geografia médica eram realizados por médicos, onde a geografia aparecia apenas como uma disciplina auxiliar $e$ a Cartografia como instrumento.

'Higiene é a antiga denominação, hoje totalmente abandonada, para designar a prática médica atualmente conhecida como medicina preventiva (cf. Forattini, 1992)

${ }^{7}$ Estudos empíricos de tipo regional, anterior aos impulsionados pela geografia. No plano teórico, uma das primeiras iniciativas de análise das inter-relações entre o homem e o ambiente.
} 
A partir da segunda metade do século $X I X$ e início do século $X X$, este enfoque "ecológico" dá lugar a um novo paradigma no estudo das enfermidades, em virtude das importantes descobertas realizadas na área de controle das doenças, com a identificação das bactérias como agente causador e a invenção da penicilina como agente curativo.

Segundo Lacaz (1972), com o sucesso dos trabalhos de Louis Pasteur sobre a etiologia das doenças infecciosas, o papel do meio físico no aparecimento das doenças ficou relegado a um plano secundário.

Frente à medicina tradicional que propunha prolongadas quarentenas e fumigações, a era bacteriológica encontra os micróbios e oferece as vacinas. (URTEAGA 1980).

Desta forma, o higienismo e a geografia médica se viram imersos em uma crise médico-científica, pois seus principais pressupostos teóricos foram negados. Perdeu-se de vista o conjunto das causas que atuam sobre o homem são ou enfermo, bem como o meio deixou de apresentar a importância que vinha assumindo para os "hipocráticos".

A "era bacteriológica" se assentou sobre novas bases de explicação reorientando por completo as linhas de investigação dos médicos (concepção das enfermidades como fenômeno puramente biológico, investigação experimental em laboratórios, etc.).

Para Andrade (2000), a partir de 1900, com o advento da microbiologia, publicam-se poucas obras sobre Geografia Médica como um todo; porém, alguns de seus temas, como a climatologia médica, por exemplo, desenvolveram-se paulatinamente.

Este fato relaciona-se, sobretudo, ao advento da Segunda Guerra Mundial, quando se tornava necessário o conhecimento dos climas e demais aspectos relacionados à Geografia Médica para a proteção, em diferentes ambientes, dos soldados em guerra.

Para Ribeiro (1988, p.13), um pequeno número de geógrafos se incumbiu de estudar os problemas de saúde relacionados ao meio. Sorre e 
Humboldt foram dos poucos que dedicaram parte de suas obras a comentar as relações existentes entre doenças e aspectos geográfico.

A meados do século $X X$, o geógrafo francês Max Sorre introduz dois conceitos geográficos associados à proposta de desenvolver a Geografia Médica: ecúmeno e complexo patogênico.

O ecúmeno é definido como o espaço de relações entre organismos vivos (vegetais e animais) e os grupos humanos, incluindo as transformações de ambos os componentes; e o complexo patogênico como uma unidade biológica de ordem superior que inclui além do homem, o agente, seus vetores e todos os organismos vivos que condicionam ou comprometem sua existência. Considera que eles se estabelecem e desarticulam segundo as condições de sua evolução e que cada doença daria nome aos múltiplos complexos existentes, como o da peste, da malária e da doença do sono, por exemplo. (SORRE, 1955)

O conceito de complexo patogênico relaciona-se diretamente com a possibilidade da saúde do homem ser afetada na sua relação com o meio, sobretudo, pelas doenças infecciosas e parasitárias. Eles são considerados por Sorre como infinitos, em número e variedade, e seu conhecimento constitui a base de toda a Geografia Médica.

Paraguassu-Chaves (2001) ilustra bem este ponto de vista, quando afirma que os conceitos desenvolvidos por Max Sorre, especificamente o de complexo patogênico, podem ser utilizados em estudos atuais, desde que redimensionados às novas concepções teórico-metodológicas da Geografia e da Epidemiologia.

De acordo com Moraes (1988), cabe enfocar alguns aspectos relevantes de sua obra, em virtude de sua grande contribuição para o desenvolvimento teórico-metodológico da geografia e da Geografia Médica, em particular. Sorre começou a publicar sua obra principal (Os fundamentos da Geografia Humana) 
em 1943, época em que a escola geográfica francesa ${ }^{8}$ tinha no paradigma "possibilismo geográfico" a base explicativa da ação do homem sobre a natureza. Esta objetivava, sobretudo, contra-atacar a escola alemã, cujas bases se assentavam no determinismo da natureza sobre a ação do homem.

Segundo Sorre:

A Geografia Médica, ramo da Geografia, como esta comporta um duplo ponto de vista: geral e regional. No ponto de vista geral o geógrafo procura determinar a extensão de um fenômeno na superfície do globo. $A$ geografia das doenças seria o equivalente da climatologia geral ou da morfologia. O ponto de vista regional baseia-se no fato de que, cada região se assinala por uma associação de endemias ou de epidemias relacionadas com os restantes característicos geográficos, físicos, biológicos e humanos (Sorre apud Pessoa 1960, p. 1).

Apesar da elevada justificação "biológica", pode-se considerar fundamental os aportes teóricos deste autor, pois destacou a importância do espaço na ocorrência de doenças transmissiveis e incorporou fatores sociais na justificativa de aparição destas doenças.

Segundo Ribeiro (1988), Sorre se insere na terceira corrente do pensamento geográfico (Método Regional), quando aborda a Ecologia das doenças e sua distribuição espacial como objeto de estudo da Geografia Médica.

No Brasil, o médico, sociólogo e geógrafo Josué de Castro, também procurou abordar as causas naturais e sociais no desenvolvimento de doenças.

8 A geografia francesa, deste período, defendia e difundia sua teoria sob a liderança de Vidal de La Blache; de quem Sorre recebeu fortes influências.

9 Corrente elaborada por Vidal de la Blache, procura demonstrar que a natureza exerce influência sobre o homem, mas que o homem tinha possibilidades de modificar e de melhorar 0 meio. 
Em sua obra, "Geografia da Fome", escrita em 1946, estudou a relação entre a miséria, a fome e o subdesenvolvimento.

Com efeito, afirmou que (...) um dos grandes obstáculos ao planejamento de soluções adequadas ao problema da alimentação dos povos reside exatamente no pouco conhecimento que se tem do problema em conjunto, como um complexo de manifestações simultaneamente biológicas, econômicas e sociais. (CASTRO 1982, p.31).

Para ele, grande parte dos estudos científicos sobre o assunto se limitava a um dos aspectos (biológico, econômico e social), projetando uma visão unilateral do problema.

Desta forma, o enfoque ecológico desenvolvido anteriormente é lentamente substituído por um enfoque social no estudo da etiologia das doenças, como destacam Lacaz e Pessoa.

Lacaz (1972, p.19), aponta que (..) para melhor se entender os mecanismos de uma doença em qualquer população humana, se torna necessário encarar o homem no seu ambiente físico, biológico e sócioeconômico.

Pessoa (1960), afirma que o "agente etiológico" é condição imprescindível para a ocorrência das doenças infecciosas, mas a distribuição e a prevalência de tais doenças na superfície na superfície da Terra, bem como o seu comportamento nas várias comunidades, são influenciadas por fatores mesológicos ${ }^{10}$, econômicos, humanos e sociais.

Lacaz e Pessoa também enfatizam a importância de se estudar as doenças por um contexto físico, econômico e social, mas sem a perspectiva de denúncia que faz Castro em sua obra.

\footnotetext{
${ }^{10}$ Relativo à Mesologia. Estudo das relações entre os seres vivos e o meio. KOOGAN LAROUSSE (1979)
} 
Posteriormente, novas possibilidades metodológicas são postas à disposição da geografia com o desenvolvimento das tecnologias quantitativas incorporadas, pioneiramente, pelos médicos norte-americanos.

O uso da computação para a produção de mapas e as possibilidades de se aplicar novas técnicas estatísticas e modelos de estudos de ocorrência e distribuição de doenças permitiu a produção de uma grande quantidade de estudos sob uma perspectiva quantitativa (DINA e RIBEIRO 2000).

A partir da década de 1970, com a conscientização da crise ambiental este novo aspecto passa a fazer parte dos estudos de Geografia Médica. Ela se torna mais crítica, segundo Ribeiro (1998), mas ainda mantém uma abordagem tecnicista para a questão ambiental.

Entre as décadas de 1970 e 1980, a corrente da Geografia Crítica (crítica a abordagem clássica e quantitativa) propõe, sobre a base da teoria marxista, novas formas para a compreensão das relações entre o homem e a natureza. Procura entender as relações dialéticas entre as formas espaciais e os processo históricos que modelam os grupos sociais.

Também a Cartografia Médica teve grande desenvolvimento nas últimas décadas, em que pese o interesse em mapear aspectos de doenças ser bastante antigo. Barrett (2000) destaca que os mapas antigos de doenças devem ter se desintegrado, pois eram desenhados à mão, em número único e em material de pequena duração. $O$ desenvolvimento recente se deu por uma série de fatores: a) desenvolvimento de instrumentos técnicos que permitiram desenhar mapas de base com precisão; b) avanços na impressão de imagens com qualidade, que permitiam uma tiragem maior de exemplares; c) o acúmulo de dados médicos e epidemiológicos que viabilizava a representação espacial dos dados e conseqüentemente a "plotação" dos dados num mapa. Vêm sendo feitos mapas temáticos de saúde, que permitiram novas formas de pensar fenômenos. Ainda segundo Barrett:

Se a Geografia Médica é a análise das relações humano-ambientais de doenças, nutrição e sistemas de saúde, e a cartografia médica é o mapeamento 
das relações médico-geográficas, a plotagem de qualquer fenômeno destas categorias num mapa é um aspecto da cartografia médica (BARRETT, 2000, p. 474).

Entretanto, a cartografia é só uma etapa da Geografia Médica. Pois, ao definir a Geografia como a ciência do espaço, temos que trabalhar com todos seus componentes, como recomenda Milton Santos: a forma, a função, a estrutura e os processos (SANTOS, 1999). Ou seja, por trás da distribuição espacial dos fenômenos (forma), temos que tentar entender o porque daquela distribuição espacial (fatores conjunturais e estruturais) e sua dinâmica.

Segundo Forattini (1992), o mapa constitui-se em valioso instrumento de pesquisa que propicia a análise e a formulação de hipótese, permitindo estabelecer possíveis associações com os vários determinantes. Para Ribeiro (2005), a análise geográfica pode contribuir para o desvendamento de causas e conseqüências e, portanto, para o avanço do conhecimento na área de saúde pública. A definição da escala adequada de estudo e de mapeamento, entretanto, é de importância crucial para detectar as variações espaciais mais significativas e as relações entre elas e as variáveis ecológicas, demográficas, sociais, culturais e econômicas (RIBEIRO, 2005, p. 66).

A crescente urbanização, no mundo em geral e no Brasil em particular, trouxe novos desafios para a Geografia Médica, ou Geografia da Saúde, como ela tem sido denominada mais recentemente, numa perspectiva de não trabalhar só com aspectos médicos e da doença, mas num enfoque mais preventivo e de promoção da saúde. Como já mencionado na introdução deste trabalho, as causas externas de adoecimento e morte ganharam uma nova face: houve uma diminuição da incidência de doenças infecciosas ligadas aos fatores exógenos e um aumento da incidência de causas externas relacionadas à violência e ao crime.

Segundo WHO (2004), os efeitos do crime na saúde e no bem-estar humano são disseminados: 
- Diretamente, através da violência, lesões, estupros e outras agressões às pessoas;

- Indiretamente, através de conseqüências psicológicas e físicas das agressões, vitimização e isolamento por causa do medo;

- Como um determinante de doenças, junto com a pobreza e outras desigualdades, que aumentam os efeitos da má saúde naquelas comunidades menos capazes de enfrentar o problema;

- Com redução da efetividade do sistema de atendimento à saúde, através da violência contra seus trabalhadores, de danos aos pacientes e ao patrimônio dos serviços de saúde;

- Através de aspectos de possível prevenção, como crimes relacionados ao consumo de álcool, acidentes, problemas de saúde mental e dependência e uso de drogas (WHO, 2004, p. 101).

O mapeamento dos agravos causados pela violência urbana e de fatores correlatos é fundamental quando se considera a necessidade de vigilância e enfrentamento da problemática.

De acordo com Costa (2005), é neste momento que se fazem presentes contribuições da ciência e da tecnologia computacionais, que reduziram as restrições para produção de mapas com relação a custo e tempo. Podem ser produzidos e utilizados vários mapas computadorizados de diferentes escalas e a facilidade para superposição de informações permite ao usuário escolher as análises mais adequadas e desejadas, de forma interativa e rápida. Os Sistemas de Informações Geográficas (SIG) desenvolvem-se, então, como ferramentas importantes de auxílio aos estudiosos da saúde ambiental (COSTA, 2005). 
Rojas e Barcellos (2003) consideram que a utilização de técnicas de análise espacial, como o geoprocessamento, são meios de aproximação com a realidade e não constituem um fim em si. Entretanto, consideram os mapas recursos essenciais, especialmente quando acompanhados de trabalho de campo operativo e investigativo. Comentam que a implantação do Sistema Único de Saúde (SUS), no Brasil, baseando-se em unidades administrativas de saúde e em articulação com os diferentes níveis de atenção, revela a importância de se identificar unidades relativamente homogêneas em condições de vida $e$, no interior destas unidades, definir pontos ou áreas de maior vulnerabilidade ante as enfermidades ou morte, dando ênfase na territorialidade humana (ROJAS e BARCELLOS, 2003).

No item a seguir, discutiremos mais aprofundadamente as relações entre as ferramentas tecnológicas disponibilizadas pelos Sistemas de Informação Geográfica (SIG) e a gestão de questões de saúde pública.

\subsection{Sistemas de Informação Geográfica (SIG)}

As novas conquistas tecnológicas resultaram em enorme incremento dos meios de informação. Mas o grande desafio da humanidade nos anos vindouros será o de usar os dados assim auferidos para melhor entender o nosso mundo natural. Dessa maneira poderiamos manter os processos ecológicos, preservar a biodiversidade $e$ incrementar a qualidade da vida humana.(FORATTINI, 2004, p.558). 


\subsubsection{Evolução dos Sistemas de Informação Geográfica (SIG)}

Os primeiros Sistemas de Informação Geográfica (SIG), com fins civis, surgiram na década de 1960, no Canadá, como parte de um programa governamental para criar um inventário de recursos naturais (CÂMARA et al. 2000).

Estes sistemas, no entanto, eram muito difíceis de se utilizar, pois não existiam monitores gráficos de alta resolução, os computadores necessários eram excessivamente caros e a mão de obra especializada era escassa. Não havia soluções comerciais prontas para seu uso e cada interessado precisava desenvolver seu próprio software ${ }^{11}$. Além disto, a capacidade de armazenamento e a velocidade de processamento dos equipamentos eram muito baixas.

Ao longo dos anos 1970 foram criados novos e mais acessíveis recursos de hardware ${ }^{12}$, tornando viável o desenvolvimento de sistemas comerciais. Foi também nesta época, que começaram a surgir os primeiros sistemas comerciais de $\mathrm{CAD}^{13}$, que melhoraram, em muito, as condições para a produção de desenhos e plantas para engenharia, e serviram de base para os primeiros sistemas de cartografia automatizada.

Neste período, também foram desenvolvidos alguns fundamentos matemáticos voltados para a cartografia, incluindo questões de geometria computacional. No entanto, devido aos altos custos e ao fato destes sistemas ainda utilizarem exclusivamente computadores de grande porte, apenas grandes organizações tinham acesso à tecnologia.

No decorrer dos anos 1980, com a grande popularização e barateamento das estações de trabalho gráficas, além do surgimento e evolução dos computadores pessoais e dos sistemas gerenciadores de bancos de dados,

\footnotetext{
11 Software - Conjunto das atividades que têm por objeto a concepção e utilização de calculadores eletrónicos para executar funções como codificação, análise e programação.

12 Hardware - Parte física do computador, composta por equipamentos como peças, encaixes, fios e chips".

${ }^{13}$ CAD - Computer Aided Design, ou projeto assistido por computador.
} 
ocorreu uma grande difusão do uso dos SIG. A incorporação de muitas funções de análise espacial proporcionou um alargamento do leque de aplicações dos SIG. Nos EUA, a criação dos centros de pesquisa que formam o NCGIA National Centre for Geographical Information and Analysis - (NCGIA 1989 in CÂMARA 2000) marcaram o estabelecimento do Geoprocessamento como disciplina científica independente.

A introdução do Geoprocessamento no Brasil inicia-se a partir do esforço de divulgação e capacitação de profissionais como o professor Jorge Xavier da Silva (UFRJ), no início dos anos 1980.

De acordo com Câmara et al. (2000), a vinda ao Brasil, em 1982, do Dr. Roger Tomlinson, responsável pela criação do primeiro SIG (o Canadian Geographical Information System), incentivou o aparecimento de vários grupos interessados em desenvolver esta tecnologia, entre os quais podemos citar:

- O grupo do Laboratório de Geoprocessamento do Departamento de Geografia da UFRJ, sob a orientação do professor Jorge Xavier, desenvolveu o SAGA (Sistema de Análise Geo-Ambiental). O SAGA tem seu forte na capacidade de análise geográfica e vem sendo utilizado com sucesso com veículo de estudos e pesquisas;

- Os então responsáveis pelo setor de informática da empresa de aerolevantamento AeroSul criaram, em meados dos anos 1980, um sistema para automatização de processos cartográficos. Posteriormente, constituiram empresa MaxiDATA e lançaram o MaxiCAD, software largamente utilizado no Brasil, principalmente em aplicações de Mapeamento por Computador. Mais recentemente, o produto dbMapa permitiu a junção de bancos de dados relacionais a arquivos gráficos MaxiCAD.

- O Centro de Pesquisa e Desenvolvimento da TELEBRÁs iniciou, em 1990, o desenvolvimento do SAGRE (Sistema Automatizado de Gerência da Rede Externa), uma extensiva aplicação de Geoprocessamento no setor de telefonia. Construido com base num ambiente de um SIG, o SAGRE envolve um significativo desenvolvimento e personalização de software. 
- O Instituto Nacional de Pesquisas Espaciais (INPE), que em 1984 estabeleceu um grupo específico para o desenvolvimento de tecnologia de geoprocessamento e sensoriamento remoto (a Divisão de Processamento de Imagens - DPI). De 1984 a 1990 a DPI desenvolveu o SITIM (Sistema de Tratamento de Imagens) e o SGI (Sistema de Informação Geográfica), para ambiente PC/DOS, e, a partir de 1991, o SPRING (Sistema para Processamento de Informações Geográficas).

A década de 1990 foi marcada por um grande crescimento do ritmo de penetração dos SIG nas organizações, impulsionado pelos custos decrescentes dos hardwares e softwares, pelo desenvolvimento de sistemas computacionais com maior capacidade de processamento e armazenamento, pelo surgimento de alternativas menos custosas para a construção de bases de dados geográficas, pelo compartilhamento das informações via redes eletrônicas $^{14}$, e também pela maior divulgação das facilidades do sistema.

Segundo o Carvalho et al, 2000, na área de ambiente e saúde, foram desenvolvidos diversos produtos $e$ bases de dados em formato digital (especificos para SIG). Mas a utilização destes produtos tem sido limitada por deficiência na sua integração, má qualidade das bases confeccionadas e sua tímida divulgação.

\subsubsection{Geoprocessamento e Sistemas de Informação Geográfica (SIG)}

O termo geoprocessamento denota o conjunto de tecnologias de coleta e tratamento de informação geográfica e de desenvolvimento e uso de sistemas que as utilizam.

Segundo Carvalho et al.:

O geoprocessamento é um termo amplo, que engloba diversas tecnologias de tratamento e manipulação de dados geográficos, através de programas

\footnotetext{
${ }^{14}$ A rede é um sistema de hardware e de software através do qual sistemas computacionais diferentes podem se comunicar.
} 
computacionais. Dentre essas tecnologias, se destacam: o sensoriamento remoto, a digitalização de dados, a automação de tarefas cartográficas, a utilização de Sistemas de Posicionamento Global - GPS e os Sistemas de Informações Geográfica - SIG. (CARVALHO et.al 2000, p.14)

De acordo com MINISTÉRIO DA SAÚDE (2000), o SIG é uma das técnicas de geoprocessamento, a mais ampla delas, uma vez que pode englobar todas as demais, mas nem todo geoprocessametno é um SIG; conforme demonstra a Figura 1.

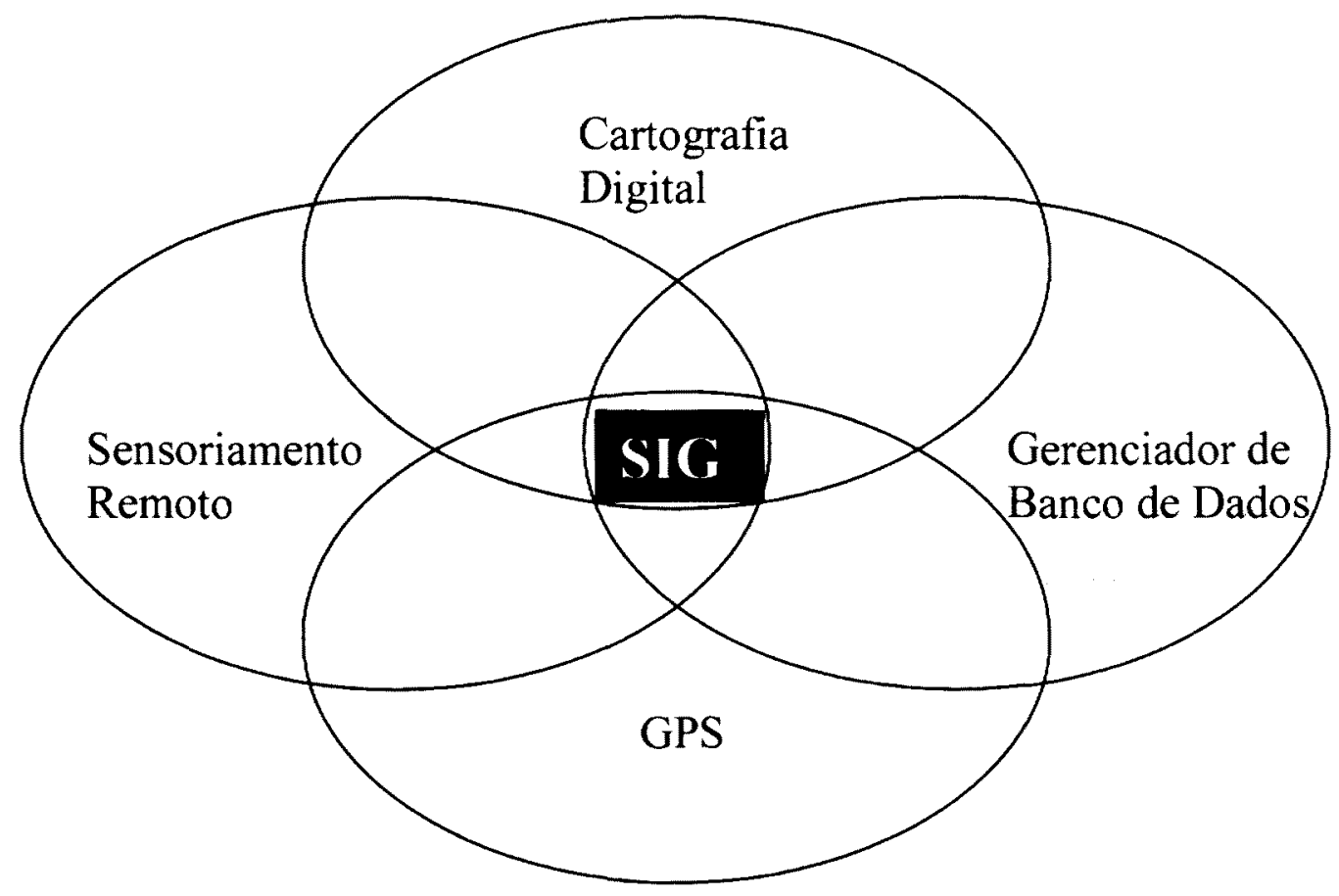

Figura 1 - Esquema representativo da integração de técnicas.

Fonte: Adaptado de Maguire, Goodchild, Rhind (1991). 
As ferramentas computacionais para geoprocessamento, denominadas Sistemas de Informação Geográfica (SIG), permitem a realização de análises complexas ao integrar dados de diversas fontes, criando bancos de dados georreferenciados ${ }^{15}$, e automatizando a produção de cartas, plantas e mapas, além de proporcionar a visualização da distribuição espacial de um fenômeno e o acompanhamento de seu desenvolvimento temporal.

Algumas definições para Sistemas de Informação Geográfica (SIG) podem ser destacadas, tais como:

- Conjunto poderoso de ferramentas para coletar, armazenar, recuperar, transformar e visualizar dados sobre o mundo real. (BURROUGH, 1998);

- Um banco de dados indexados espacialmente, sobre o qual opera um conjunto de procedimentos para responder a consultas sobre entidades espaciais. (SMITH et al., 1987);

- Um sistema de suporte à decisão que integra dados referenciados espacialmente num ambiente de respostas a problemas. (COWEN, 1988), e

- Um conjunto manual ou computacional de procedimentos utilizados para armazenar e manipular dados georreferenciados. (ARONOFF, 1989).

Essas definições de SIG refletem, cada uma à sua maneira, a multiplicidade de usos e visões possíveis desta tecnologia e apontam para a perspectiva interdisciplinar de sua utilização.

Como um sistema de suporte à decisão, o SIG pode ser aplicado em áreas como a geografia, o planejamento urbano e ambiental, a agricultura, a cartografia, em cadastramento urbano, redes concessionárias (água, energia elétrica), mercado, educação, segurança e saúde pública, pois permite a execução de procedimentos lógicos e matemáticos sobre as variáveis georreferenciadas, com uma economia de expressão e rentabilidade impossiveis de serem alcançadas em análises tradicionais.

${ }^{15}$ Georreferência: referência a um sistema de posicionamento global, através do uso de um sistema de projeção, Datum e coordenadas geográficas. 
Devido a sua ampla gama de aplicações, há pelo menos três grandes formas de se utilizar este sistema, segundo Medeiros (1999):

- Como ferramenta para produção de mapas;

- Como suporte para análise espacial de fenômenos, e

- Como banco de dados geográficos, com funções de armazenamento e recuperação de informações espaciais.

Estas principais formas de uso de um SIG são antes convergentes que conflitantes e refletem a importância relativa do tratamento da informação geográfica, no desenvolvimento de projetos temáticos.

Os produtos criados são arquivos digitais contendo mapas, gráficos, tabelas e relatórios convencionais, que contribuem para o entendimento dos fatos e fenômenos analisados.

Um SIG permite responder a perguntas do tipo:

- Localização: onde está?

- Condição: como está?

- Tendência: o que mudou?

- Roteamento: por onde deve passar?

- Padrões: qual é a distribuição?

- Modelos: o que aconteceria se?

Desta forma, os Sistemas de Informação Geográfica (SIG) possibilitam a integração de informações de forma ágil e precisa, com fins a geração de cenários que fomentem pesquisadores e gestores em suas análises.

\subsubsection{Base de Dados num SIG}

As bases de dados dos SIG são formadas pelas componentes gráficas (mapas) e não-gráficas, ou alfanuméricas (tabelas).

As componentes gráficas e não-gráficas dos dados espaciais têm características distintas, por isso exigem técnicas particulares para seu gerenciamento. 
Em grande parte dos programas (SIG), as duas componentes ficam armazenadas em bases de dados distintas, onde os dados gráficos são manuseados diretamente pelo programa e os não-gráficos são gerenciados por Sistemas Gerenciadores de Banco de Dados (SGBD) convencionais (ARONOFF, 1989).

Um Sistema Gerenciador de Banco de Dados (SGBD) consiste de uma coleção de dados inter-relacionados e de um conjunto de programas para acessá-los.

Um SIG contemporâneo, segundo Câmara (1995), integra um SGBD e simplifica alguns serviços para o programador, tais como:

- Armazenagem e recuperação de dados;

- Acesso lógico, independente da estrutura de armazenamento físico;

- Acesso a dados padronizados;

- Definição de restrições de consistência para serem automaticamente impostas;

- Controle de acesso concorrente por múltiplos usuários; e

- Proteção contra perda ou acesso não autorizado.

A forma usual de integração das informações geográficas com um ambiente de banco de dados faz uso do SGBD relacional para armazenar os atributos convencionais dos objetos geográficos (na forma de tabelas) e arquivos para guardar as representações geométricas. No modelo relacional, os dados são organizados na forma de uma tabela onde as linhas correspondem aos geo-objetos e as colunas correspondem aos atributos conforme demonstra a Figura 2. 


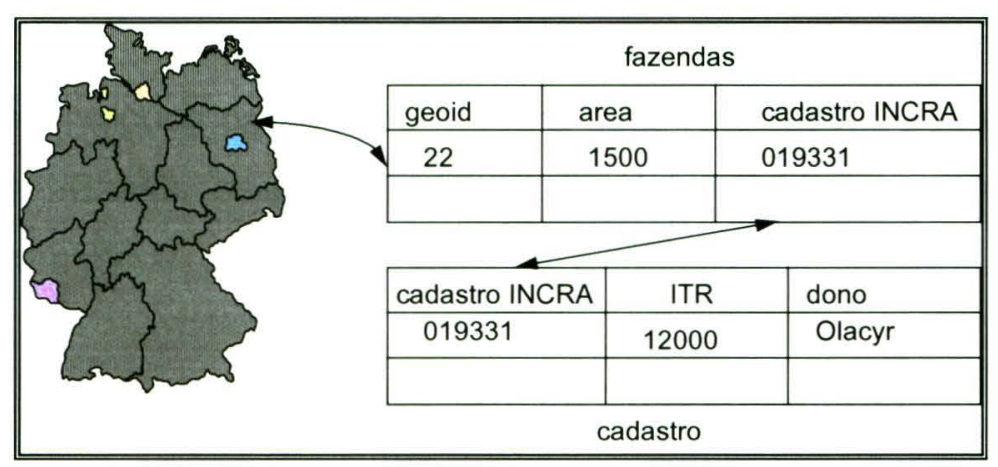

Figura 2 - Estratégia dual para bancos de dados geográficos.

Fonte: Câmara (1995 p. 2-9).

A partir desta organização, um SIG é capaz de associar a representação gráfica com a informação descritiva contida em seu banco de dados e também de computar novas informações e exibi-las sob a forma de mapas. Assim, para obter informações sobre estradas como, tipo de pavimento, largura, comprimento ou número de vias, pode-se consultar o dado não-gráfico (atributos) correspondente e apresentar os resultados de forma inteligível.

\subsubsection{Conexão Entre Dados Gráficos e Não-Gráficos}

A conexão entre o dado gráfico (espacial) e o não-gráfico (alfanumérico) é fundamental em um SIG.

De acordo com Câmara (1995), para que isto ocorra existem três condições que devem ser mantidas:

- Um relacionamento único entre dados gráficos sobre o mapa e registros na tabela de atributos;

- A ligação entre o dado gráfico e o registro através de um único identificador, e

- O identificador armazenado fisicamente no arquivo que contém os dados gráficos e no arquivo que contém o correspondente registro da tabela de 
atributos.

Os identificadores são utilizados como um meio de ligação entre as representações gráficas do mapa e seus respectivos atributos tabulares e viceversa. Essas operações fornecem interatividade entre dados gráficos e alfanuméricos.

\subsubsection{Base de Dados Não-Gráficos (Alfanuméricos)}

A base de dados alfanuméricos é formada por dados atributivos. Os dados atributivos fornecem informações descritivas acerca das características das feições gráficas. Eles estão ligados aos elementos gráficos através de identificadores comuns, normalmente chamados de geocódigos, que estão armazenados tanto nos registros não gráficos, como nos gráficos (Ministério da Saúde, 2000).

A grande maioria dos programas (SIG) estrutura seus dados através de tabelas, nas quais cada linha corresponde a uma ocorrência, e cada coluna a um atributo da entidade.

Assim, as tabelas ou banco de dados associados a uma base gráfica, descrevem eventos ou fenômenos físicos que ocorrem numa localidade geográfica específica. Estes dados representam os eventos ou ações que se quer mapear, como por exemplo: furtos, roubos ou homicidios que podem ser relacionados com suas localizações geográficas específicas, como domicílios, distritos e setores censitários, etc.

\subsubsection{Base de Dados Gráficos}

Os dados gráficos formam a imagem do mapa; eles apresentam uma posição geográfica com relação a um sistema de referência, atributos geométricos e relacionamentos espaciais. 
Segundo Antenucci et al. (1992), citados por Ministério da Saúde (2000, p.44), os dados gráficos podem ser enquadrados em quatro componentes principais:

- Posição Geográfica: caracteriza a posição de um objeto em relação a um sistema de referência qualquer;

- Atributos Geométricos: tem a finalidade de descrever os objetos geometricamente;

- Tempo: referencia as informações geográficas a uma época ou período no tempo, e

- Relacionamentos Espaciais ou topologia: referem-se à posição de um objeto em relação aos demais que pode ser de: adjacência, conectividade, contingência e proximidade.

Os dados gráficos, geralmente, são organizados em planos de informação (layers), ou camadas que contém feições gráficas. Cada camada representa um tema com feições homogêneas. Um mapa pode agregar um grande número de camadas.

\subsubsection{Estrutura de Dados Gráficos}

\subsection{Modelo Vetorial (Vector)}

O modelo de dados gráficos vetoriais define precisamente todas as posições, comprimentos e dimensões das entidades geográficas. Este formato é, em geral, resultado da digitalização de cartas. Consiste normalmente de listas de coordenadas 2D que delimitam regiões temáticas, ou representam redes que podem ter associada uma terceira grandeza. EX.: eixo de logradouro.

A representação vetorial faz uso dos seguintes elementos básicos:

- Pontos: Entidades geográficas identificadas por um único par de coordenadas $(x, y)$. Usualmente, um ponto é um símbolo relacionado a qualquer entidade geográfica que não é possível representá-la em sua dimensão (área). 
- Arcos: Conjunto de coordenadas $(x, y)$ que descreve uma linha contígua no espaço. Utilizada para representar entidades que tem apenas a dimensão em comprimento, ou como limites de polígonos.

- Nós: Pontos inicial e final de cada arco. A estes nós está associada a informação de topologia (quais linhas são incidentes).

- Polígonos: Compreendem regiões limitadas por arcos. Cada polígono é construído a partir da lista de arcos que define.

Através da Figura 3, pode-se observar os elementos vetoriais básicos descritos acima.

Figura 3 - Representações vetoriais: ponto, arco, nó e polígono.

Fonte: Elaborado pela autora.

\subsection{Modelo Matricial (raster)}

Define-se o formato matricial (raster) como um conjunto de celas localizadas em coordenadas contíguas, implementadas em uma matriz 2D. Cada célula, também chamada elemento de imagem, elemento de matriz ou "pixel", é referenciada por índices de linha e coluna e contém um número representando o tipo ou valor do atributo mapeado. 


\subsubsection{Geocodificação}

A geocodificação é um método desenvolvido pelos SIG para relacionar dados gráficos e não-gráficos, de modo a se espacializar as informações contidas numa tabela.

Este processo se realiza através do armazenamento de identificadores comuns a cada grupo. Estes identificadores são códigos que relacionam os dados (gráficos e alfanuméricos) sem ambigüidade, chamados geocódigos, que quando gerados realizam a geocodificação. Exemplo: associação de um símbolo geograficamente referenciado num mapa, para cada registro de homicídio (Boletim de Ocorrência) de um município.

\subsubsection{Cartografia para SIG}

A Cartografia é a arte e ciência de representar graficamente uma área geográfica em uma superfície plana.

A representação de uma área pode incluir superposições de diversas informações, organizadas segundo convenções para criação de produtos cartográficos. Estas convenções incluem a Exatidão e Precisão; Projeção Cartográfica; Referência Cartográfica (coordenadas) e aparência gráfica (simbologia); definidas por normas especificas.

Os dados cartográficos, necessários para o desenvolvimento de um mapeamento em um SIG, devem estar em formato digital. Caso isto não ocorra, - produto analógico deve ser convertido para o formato digital e estar compativel com o sistema do software. O produto digital da conversão de dados matriciais (raster) para vetoriais (vector) pode ser obtido pelo processo de digitalização ou vetorização.

$\mathrm{Na}$ digitalização de mapas, as bases em formato analógico têm suas linhas (hidrografia, hipsografia, malha viária, dentre outros) copiadas manualmente, por meio de um cursor conectado a uma mesa digitalizadora. $\mathrm{Na}$ vetorização se visualiza o mapa, ou uma imagem, no formato matricial (raster), 
na tela do computador e se percorre, também manualmente, os segmentos lineares da imagem, com um cursor ou bastão de controle (joystick), este último é um processo recente.

Estes processos de digitalização ou vetorização de bases cartográficas se tornaram possiveis a partir do advento dos sistemas CAM (Computer Aided Mapping), que incluem o CAD, citado anteriormente.

A geração de uma base digital deve estar dentro de normas de padrões cartográficos estabelecidos para a sua confecção. Estes padrões estipulam, principalmente, a margem de erro que se pode ter na conversão de uma base do formato analógico para o digital.

Várias nações estabelecem comitês para desenvolverem padrões de dados. Três dimensões principais têm emergido:

- Terminologia Padrão;

- Especificação de transferência de dados espaciais, e

- Especificação da qualidade dos dados.

Caso exista a necessidade de uso de uma base do eixo de logradouros, deve se ter uma atenção especial, pois se esta não tenha sido elaborada dentro dos padrões cartográficos, os resultados poderão ser comprometidos.

A base de eixo de logradouros deve apresentar a maior cobertura possível do sistema viário, da área em estudo, além de uma topologia completa, na qual a nomenclatura das vias seja escrita com total fidelidade aos registros oficiais da prefeitura do município em foco.

A Figura 4 apresenta um exemplo de inconsistência, onde se pode observar a existência de trechos de ruas sem informação e áreas sem cobertura (desatualizadas), a partir da sobreposição de bases de eixo de logradouros de duas fontes. 


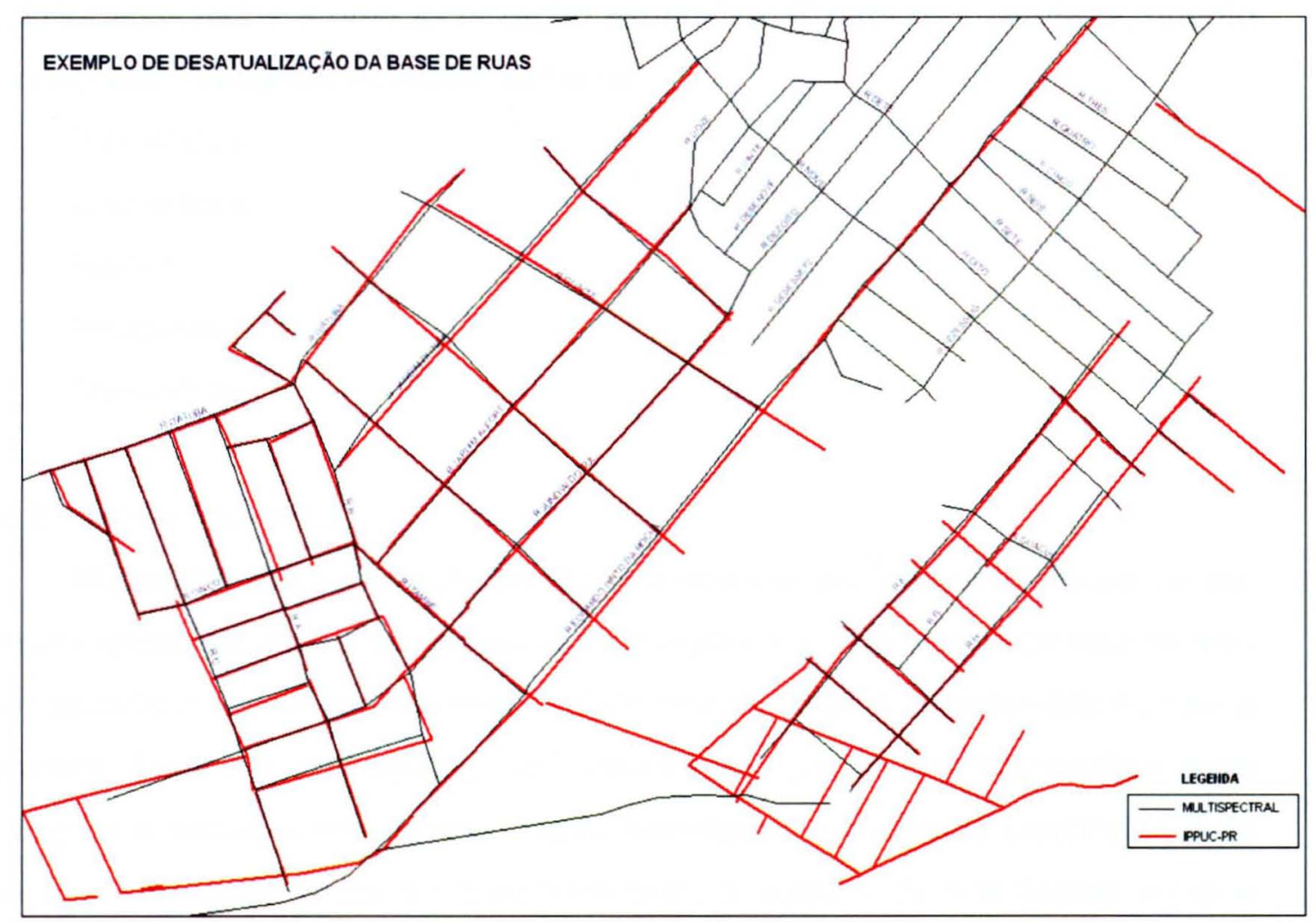

Figura 4 - Exemplo de desatualização de eixo de logradouros.

Fonte: Elaborado pela autora.

\subsubsection{Tratamento de Dados em um SIG}

Os sistemas de informação são estruturas (nem sempre computadorizadas) que permitem o armazenamento, processamento e saída de informações, que contribuem para a redução de incertezas.

De acordo com Paredes (1994), um sistema de informação tem a função de disponibilizar informações ao usuário, permitindo-lhe a tomada de decisões na pesquisa, planejamento ou gerenciamento de um evento.

Tendo em vista que informação é um conjunto de dados organizados, com significado direcionado para uma determinada aplicação (PAREDES 1994), a informação geográfica representa um conjunto de dados (físicos e 
sociais) associados a uma localização específica. E para representá-la, quanto ao conteúdo, há várias técnicas, como as:

- Temáticas;

- Cadastrais;

- Redes;

- Imagens, e

- Numéricas

\subsubsection{Mapa Temático}

Mapas temáticos são dados do tipo geo-campo ${ }^{16}$ e caracterizam-se por conter regiōes definidas por um ou mais polígonos, como mapas de uso do solo e de aptidão agrícola de uma região. Este tipo de dado é armazenado na forma de arcos (limites entre regiões), incluindo os nós (pontos de interseções entre arcos) para montar uma representação topológica. A topologia construída é do tipo arco-nó-região: arcos se conectam entre si através de nós (ponto inicial e final) e arcos que circundam uma área definem um poligono (região) (BURROUGH, 1998).

Os mapas temáticos podem ser armazenados também sob a forma matricial. A área correspondente ao mapa é dividida em células de tamanho fixo e cada célula tem um valor correspondente ao tema mais freqüente naquela localização espacial. Estas duas formas de representação são ilustradas na Figura 5.

16 Geo-campos são variações espaciais contínuas utilizadas para grandezas distribuídas espacialmente. Correspondem, como exemplo a dados temáticos, imagens e modelos numéricos de terreno. (GOODCHILD, 1992) 


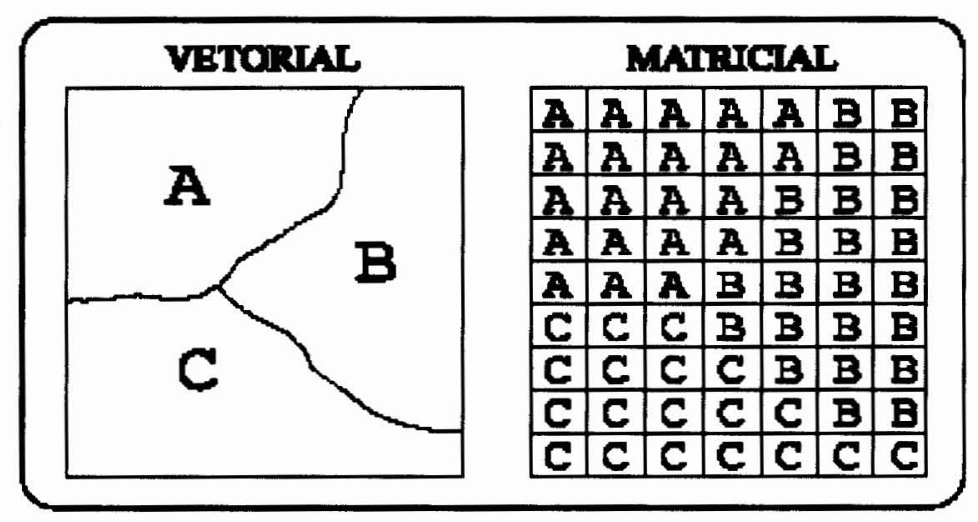

Figura 5 - Representação vetorial e matricial de um mapa temático.

Fonte: (CÂMARA 1995, p.2).

As formas de representação matricial e vetorial são utilizadas de acordo com a conveniência de cada aplicação. No Quadro 1, pode-se observar uma comparação entre as vantagens e as desvantagens de utilização desses formatos para mapas temáticos.

Quadro 1 - Comparação Entre Formatos para Mapas Temáticos.

\begin{tabular}{|c|c|c|}
\hline anpereto & lermallus sturial & formatu varredula \\
\hline relações espaciais entre objetos & $\begin{array}{l}\text {-relacionamentos topológicos } \\
\text { entre objetos }\end{array}$ & $\begin{array}{l}\text {-relacionamentos espaciais } \\
\text { devem ser inferidos }\end{array}$ \\
\hline ligação com banco de dados & $\begin{array}{l}\text {-facilita associar atributos a } \\
\text { elementos gráficos }\end{array}$ & $\begin{array}{l}\text {-associa atributos apenas a } \\
\text { classes do mapa }\end{array}$ \\
\hline $\begin{array}{l}\text { análise, simulação e } \\
\text { modelagem }\end{array}$ & $\begin{array}{l}\text {-representação indireta de } \\
\text { fenômenos contínuos } \\
\text {-álgebra de mapas é limitada }\end{array}$ & $\begin{array}{l}\text {-representa melhor fenômeno } \\
\text { com variação contínua no } \\
\text { espaço } \\
\text {-simulação e modelagem mais } \\
\text { fáceis }\end{array}$ \\
\hline escalas de trabalho & $\begin{array}{l}\text {-adequado tanto a grandes } \\
\text { quanto a pequenas escalas }\end{array}$ & $\begin{array}{l}\text {-mais adequado para pequenas } \\
\text { escalas (grandes áreas) }\end{array}$ \\
\hline algoritmos & $\begin{array}{l}\text {-problemas com erros } \\
\text { geométricos }\end{array}$ & $\begin{array}{l}\text {-processamento mais rápido e } \\
\text { eficiente }\end{array}$ \\
\hline armazenamento & $\begin{array}{l}\text {-por coordenadas (mais } \\
\text { eficiente) }\end{array}$ & -por matrizes \\
\hline
\end{tabular}

Fonte: Adaptada de Câmara (1995, p.9). 


\subsubsection{Mapa Cadastral}

Mapas cadastrais são dados do tipo geo-objeto ${ }^{17}$, onde cada elemento é um objeto geográfico, que possui atributos e pode estar associado a várias representações gráficas. Por exemplo, os lotes de uma cidade são elementos do espaço geográfico que possuem atributos (dono, localização, valor venal, IPTU, etc.) e podem ter representações gráficas diferentes, como pontos, linhas e poligonos.

Normalmente a parte gráfica dos mapas cadastrais não é representada na forma matricial. A forma mais eficiente e convencional de armazená-la é como coordenadas vetoriais, com sua topologia associada. A Figura 5 ilustra um exemplo de mapa cadastral, onde é mostrada a associação existente entre os objetos geográficos e os seus respectivos atributos.

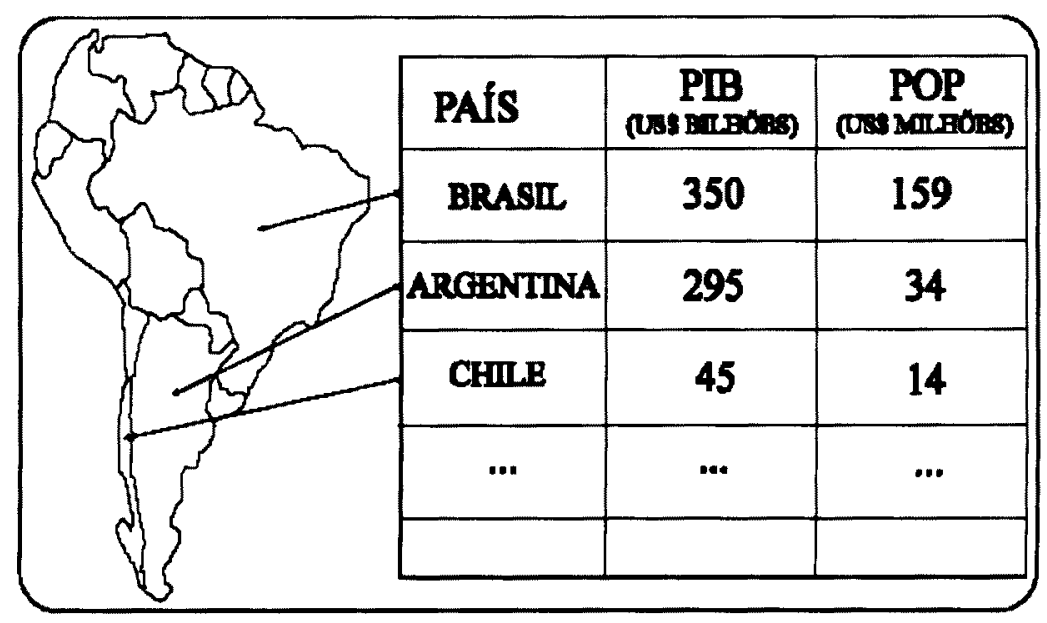

Figura 6 - Exemplo de mapa cadastral, mostrando alguns países da América do Sul com seus respectivos atributos descritivos.

Fonte: Adaptado de Câmara (1995, p.12).

\footnotetext{
17 Geo-objetos são elementos individualizáveis com identificação. Este tipo de dado tem atributos não espaciais, armazenados em um banco de dados convencional, e pode estar associado a várias representaçōes gráficas. Correspondem, como exemplo, a escolas, municípios e avenidas. (GOODCHILD, 1992)
} 
Os mapas cadastrais apresentam formatos relativamente simples e a maior parte das aplicações, que os utilizam, realizam consultas ao banco de dados e apresentam os resultados de forma simbólica. Portanto, para a realização dessas consultas, é fundamental que haja uma boa ligação entre o mapa cadastral e o banco de dados. Um geo-objeto é individualizável e tem identificação com o mundo real. Esta identificação possibilita ligar a sua representação (dados gráficos) a seus atributos (dados alfa-numéricos).

Um dado do tipo temático (geo-campo) não é identificável e nem individualizável (GOODCHILD, 1992). Portanto, as representações gráficas resultantes de uma classificação são tratadas apenas como pertencente a um certo tema ou classe.

Neste modelo é possível apenas associar atributos gerais que descrevem as classes utilizadas. Portanto, não se pode separar e associar atributos específicos a cada representação gráfica.

Um dado do tipo geo-objeto ou modelo cadastral é identificável e separável. Então, o usuário pode identificar e associar atributos descritivos a cada representação gráfica. Por exemplo, numa plantação de soja (simbolizado sobre o mapa com representações poligonais) pode-se informar, para cada polígono, o tipo de fertilizante utilizado, a marca do herbicida, o custo por hectare e o índice de produção.

Neste modelo, os polígonos de soja são denominados de objetos geográficos e podem ser manipulados através do sistema, para serem exibidos em gradação de cores de acordo com o índice de produção, ou de acordo com o tipo de fertilizante utilizado. Isto é possível, porque cada polígono tem atributos descritivos, que permitem ao sistema analisá-lo e exibi-lo de forma adequada.

\subsubsection{Redes}

Redes também são do tipo geo-objeto e se caracterizam por cada objeto (por exemplo: um cabo telefônico, transformador de rede elétrica ou cano de 
água) possuir uma localização geográfica exata e estar associado a atributos descritivos, presentes no banco de dados.

Os dados de redes são compostos por informações associadas a serviços de utilidade pública, como água, luz, telefone, redes de drenagem (bacias hidrográficas), malhas viárias, etc.

As informações gráficas de redes são armazenadas em coordenadas vetoriais, com topologia arco-nó: arcos têm um sentido de fluxo e nós têm atributos que podem ser fontes ou sorvedouros. Neste tipo de dado (da mesma forma que no cadastral) também é fundamental a ligação com banco de dados, para que se possa realizar consultas e apresentar os resultados de forma adequada. Estes tipos de dados são mais complexos de serem tratados que dados cadastrais. Normalmente os pacotes de rede de sistemas comerciais possuem cálculos de caminho ótimo e crítico, mas nem sempre são suficientes para a exigência das aplicações (PEUQUET, 1990).

\subsubsection{Imagens}

Imagens são do tipo geo-campo, obtidas por satélites ou aeronaves e armazenadas como matrizes, onde cada elemento unitário de informação ( $p i x e l$ ) está ligado a certas características físicas e/ou químicas do material da superfície. O uso de imagens de satélite tem se tornado comum em SIG e suas características mais importantes são: resolução espectral (número de bandas); resolução espacial (a área unitária da superfície terrestre observada instantaneamente por cada sensor); resolução temporal (intervalo de tempo entre passagens sucessivas sobre uma mesma área), e resolução radiométrica (capacidade de conversão da energia captada pelo sensor em "bits").

\subsubsection{Modelos Numéricos de Terreno (MNT)}

Modelos Numéricos de Terreno (MNT) também são do tipo geo-campo e denotam a representação quantitativa de uma grandeza (intervalo de referência arbitrária) que varia continuamente no espaço. Um MNT é normalmente 
associado a altimetria, mas pode ser utilizado para modelar outros fenômenos de variação contínua, tais como variáveis geofísicas, geoquímicas, batimetria e temperatura. Em MNT podem ser utilizados dois tipos de representações:Grades regulares: matriz de elementos com espaçamento fixo, onde é associado o valor estimado da grandeza na posição geográfica de cada ponto da grade, e

- Malhas triangulares: a grade é formada por conexão entre amostras do fenômeno, utilizando, por exemplo, a triangulação de Delaunay $2^{18}$. A grade triangular é uma estrutura topológica vetorial do tipo arco-nó formando recortes triangulares do espaço. Uma comparação mostrando as vantagens e desvantagens destas duas formas de representação de MNT é ilustrada no Quadro 2.

Quadro 2 - Vantagens e desvantagens da Grade Triangular e Regular para a Representação de MNT.

\begin{tabular}{|c|c|c|}
\hline & grade triangular & grade regular \\
\hline Vantagens & $\begin{array}{l}\text { - melhor representação de relevo } \\
\text { complexo } \\
\text { - pode incorporar restriçòes como } \\
\text { linhas de crista }\end{array}$ & $\begin{array}{l}\text { - facilidade de manuseio e conversão } \\
\text { - adequada para geofísica e } \\
\text { visualizaçào 3D }\end{array}$ \\
\hline Desvantagens & $\begin{array}{l}\text { - complexidade de manuseio } \\
\text { - inadequado para visualização } 3 \mathrm{D}\end{array}$ & $\begin{array}{l}\text { - ruim para representação de relevo } \\
\text { complexo } \\
\text { - ruim para cálculo de declividade }\end{array}$ \\
\hline
\end{tabular}

Fonte: Adaptado de Câmara (1995, p.17).

\footnotetext{
${ }^{18}$ A triangulação de Delaunay garante que o circumcírculo de cada triângulo não contém nenhum outro ponto de outra triangulação.
} 


\subsubsection{O Papel dos SIG na Análise Criminal}

O conhecimento da distribuição espacial da criminalidade pode ser um valioso instrumento no auxílio a seu combate e prevenção. Seu padrão geográfico pode fornecer informações sobre sua origem e subsidiar uma análise teórica preliminar.

Neste contexto, os Sistemas de Informação Geográfica (SIG), surgem como uma ferramenta de grande valor no tratamento de dados criminais. De forma ágil e a baixos custos, fornece suporte ao gerenciamento dos crimes estudados, e possibilita sua integração com outras bases de dados.

Mas a implantação dos Sistemas de Informação Geográfica (SIG), no mapeamento do crime, requer a definição de alguns padrões para tratamento das informações que se inicia na escolha das bases cartográficas digitais da área em estudo.

Para que o trabalho de análise criminal seja eficaz, é preciso um investimento na preparação $e$ integração das diversas bases e fontes de informação disponiveis, na medida em que as ações policiais, constantemente, requerem um conhecimento detalhado das áreas que serão alvo da intervenção.

Com efeito, o mapeamento dos agravos causados pela violência urbana e de fatores correlatos é fundamental quando se considera a necessidade de vigilância e enfrentamento da problemática; tendo sempre em vista o conceito de que "a quantidade só faz sentido como dado da qualidade" (MARTINS 1996, p.307). 


\section{METODOLOGIA}

A ciência a tecnologia e a informação estão na base de todas as formas de utilização e funcionamento do espaço (...), (...) desempenhando um papel de suma importância na edificação das sociedades, na intenção de responder com precisão aos "desafios deste novo milênio". (ROSA et. al 2005, p.29)

Tendo em vista que novas problemáticas interdisciplinares ${ }^{19}$ infundem novas exigências de produção do conhecimento, o campo da Saúde Pública, objeto desta pesquisa, não é passivel de ser englobado ou reduzido a uma única disciplina (BRUYNE 1882 apud ALVARENGA 1994, p.24). Para tanto, este estudo foi encaminhado agregando conhecimentos das áreas de Geografia Médica, Geoprocessamento e Segurança Pública.

A Geografia Médica, como um campo do saber que se preocupa com as questões relacionadas ao espaço e o processo saúde doença, fornece uma visão mais abrangente do que a sintomatologia, podendo, portanto, ter um papel importante, juntamente com outras ciências, na concepção e no desenvolvimento de políticas de saúde pública, tanto preventivas, quanto corretivas.

As técnicas de Geoprocessamento, denominadas Sistemas de Informação Geográfica, trazem grande avanço a descrição do nivel de qualidade de vida de uma população e monitoramento de seus problemas sociais; possibilitando a captura de novas dimensões do tema tratado através

${ }^{19}$ Se compreenderá por interdisciplinaridade, o encontro e a cooperação de duas ou mais disciplinas, trazendo cada uma delas (no plano da teoria e pesquisa científica) seus próprios esquemas conceituais, sua forma de definir os problemas e seus métodos de investigação. Onde se estabeleça vínculos intencionais na compreensão e explicação do universo da pesquisa, superando, dessa forma, a excessiva compartimentalização científica provocada pela especialização das ciências modernas (COIMBRA 1985). 
da aplicação de ferramentas acessiveis de manipulação da informação, pois integram dados de diferentes fontes e formatos, de forma dinâmica. Fornecendo, assim, subsídios a uma análise interdisciplinar, a partir de novas formas de agregação de dados em superfícies.

Com as importantes alterações no perfil brasileiro de causas de morte, pelo crescimento da mortalidade associado à violência; a Saúde Pública incorporou questões referentes a Segurança Pública em seus estudos.

Segundo Mello Jorge (2004), citado por ROSA (2005, p.31), a violência é um fenômeno multifacetado, que apresenta diferentes análises, e permite, portanto, que a discussão sobre ela seja feita de forma interdisciplinar. Esta análise interdisciplinar, alicerçada em diferentes perspectivas teóricas e metodológicas, possibilita múltiplos enfoques e olhares sobre sua temática.

A partir da noção de que o conhecimento pressupõe a análise, e a análise pressupõe a divisão (SANTOS 1999), este trabalho foi estruturado na perspectiva de obter resultados sobre duas abordagens escalares. Primeiramente, construiu-se um produto espacialmente representado na escala do município, que demonstrou as informações criminais tratadas de modo homogêneo. Posteriormente, obteve-se um produto da distribuição pontual dos boletins de ocorrências selecionados, na escala do distrito policial.

Para o desenvolvimento do roteiro metodológico, se partiu da proposta elaborada por Libault (1971) em sua obra "Os Quatro Níveis da Pesquisa Geográfica". Em que o autor distingue os quatros niveis de uma pesquisa como: nível compilatório, nivel correlativo, nivel semântico e nivel normativo.

O nivel compilatório corresponde à primeira fase da pesquisa, que se apresenta em duas etapas: a coleta de dados e a seleção das informações coletadas. Nesta fase a etapa de seleção das informações, exige o domínio do conhecimento teórico-conceitual para que informações de grande significado não sejam desprezadas. 
O segundo nível, proposto por Libault, denominado correlativo, representa a fase de correlação entre os dados, para que posteriormente se possa estabelecer a interpretação.

A realização desta fase aponta para a necessidade de homogeneidade das informações. Segundo Libault, os dados devem apresentar a mesma natureza e serem obtidos no mesmo local, modo e momento.

O terceiro nível, o semântico, é definido como um nível interpretativo, em que se chega a resultados conclusivos a partir dos dados selecionados e correlacionados nas etapas anteriores.

O quarto e último nível, determinado pelo autor de normativo, refere-se à fase em que 0 produto de pesquisa se transforma em modelo. Essa modelização é representada através de cartogramas síntese ou gráficos que traduzem de forma mais simples e visual os produtos da pesquisa.

De acordo com Ross (2000), a proposta metodológica de Libault, por ser de caráter geral, tem um aspecto de aplicação bastante amplo e pode ser utilizada como base, tanto para estudos de cunho geográfico de natureza sócioeconômica como para as disciplinas mais vinculadas às ciências naturais. Tanto num caso como no outro, porém, melhor se aplicam quando as informações forem trabalhadas com valores numéricos, podendo assim sofrer tratamento estatístico.

O capitulo 5 deste estudo, denominado Revisão Bibliográfica teve como finalidade, num primeiro momento, à investigação das potencialidades de articulação do referencial teórico e metodológico da geografia, no conhecimento e interpretação de questões de saúde pública, a partir do levantamento bibliográfico existente sobre a relação entre a Geografia e a Saúde Pública, por meio de livros, artigos e fragmentos de textos que abordem, em resumo: suas origens com Hipócrates em, aproximadamente, 400 a.C; seu declínio a partir das últimas décadas do século $X I X$, com a era bacteriológica; e seu ressurgimento na segunda metade do século $X X$, com o interesse pela análise integrada dos problemas de saúde pública com os aspectos ambientais. 
Num segundo momento, se realizou um levantamento bibliográfico que demonstrou a interface ${ }^{20}$ da Geografia e da Saúde Pública com os recursos tecnológicos dos Sistemas de Informação Geográfica, como suporte à gestão de questões saúde e segurança pública, a partir da abordagem de seu processo de evolução, delimitação de sua estrutura geral e das técnicas de geração de informações de seus sistemas.

No capítulo 7, Resultados e Discussão, tendo em vista a proposta de elaboração de um estudo interdisciplinar sobre segurança urbana através da utilização de materiais que possibilitem uma eficiente manipulação e armazenamento de bancos de dados e imagens, a fim de fomentar formas para capturar novas dimensões do tema tratado; apresentou-se um produto gráfico com a distribuição do crime no município de São Paulo, através da inter-relação de variáveis censitárias e bases de dados de natureza de ocorrências criminais pela aplicação de ferramentas disponiveis nos Sistemas de Informação Geográfica.

\subsection{Materiais}

\subsection{1 Área de Estudo}

A área, objeto deste estudo é compreendida pelo município de São Paulo, capital do Estado de São Paulo, localizado na região Sudeste do Brasil, sob o trópico de Capricórnio.

Suas altitudes variam de cerca de 700 a 900 metros acima do nível do mar, a uma distância aproximada de $60 \mathrm{~km}$ do Oceano Atlântico. Seu sítio geográfico é uma planície sedimentar formada pelos rios Tietê e Pinheiros, no reverso do Planalto Atlântico.

Está localizado entre as coordenadas geográficas W46036'33", S233' $80^{\prime \prime}$ e $W^{\circ} 46^{\circ} 83^{\prime} 42^{\prime \prime}, S 24^{\circ} 00^{\prime} 69^{\prime \prime}$, com uma área de $1.509 \mathrm{Km}^{2}$ (IBGE

\footnotetext{
${ }^{20}$ Dispositivo (físico ou lógico) que estabelece a adaptação entre dois sistemas independentes.
} 
2000), dos quais $273,17 \mathrm{Km}^{2}$ constituem Áreas de Proteção Ambiental. Anexo A1.

\subsubsection{População em Estudo}

O município de São Paulo cresceu muito nos últimos 150 anos, uma vez que pelo Censo de 1872 tinha somente 32.000 habitantes. As plantações de café no estado, a partir de finais do século $X I X$, foram responsáveis por intenso crescimento econômico e demográfico. Durante o século $X X$, desenvolveu-se a industrialização, favorecida pelas duas Guerras Mundiais e pela instalação da indústria automobilística na Região Metropolitana de São Paulo, na segunda metade do século.

Em poucos anos, São Paulo tornou-se a maior e mais industrializada cidade da América do Sul. As atividades econômicas se diversificaram e, por muitas décadas, a cidade atraiu imigrantes de todo o Brasil e de outros países.

$\mathrm{Na}$ última década do século $X X$, por fatores econômicos, ambientais $e$ sociais; muitas indústrias se mudaram do municipio para uma área mais ampla e distante até $100 \mathrm{~km}$ do centro urbano. Atualmente, as atividades terciárias ultrapassam a indústria em renda e em número de empregos oferecidos no município. As taxas de crescimento demográfico diminuíram, mas a cidade continua a ser o centro financeiro e cultural do Brasil e da América do Sul. É considerada uma cidade global, pois nela se situam muitos escritórios de maior parte das empresas multinacionais sediadas no país.

De acordo com o Censo de 2000, o município possui uma população de 10.434.252 habitantes, dos quais $97,7 \%$ viviam na zona urbana (IBGE, 2000). A expectativa de vida na cidade é de 71,6 anos (IBGE, 2000). Entretanto, esta é mais baixa para o sexo masculino (66,5 anos) do que para o feminino (75,5 anos), sobretudo devido aos fatores de risco mais elevados entre os homens: violência, fumo, consumo de álcool e estresse.

Em relação à estrutura etária, $44 \%$ dos habitantes possuem menos que 24 anos, sendo $30,5 \%$ entre 0 e 17 anos de idade e $13 \%$ entre 18 e 24 anos. 
Nas outras faixas etárias, a distribuição é a seguinte: $9 \%$ entre 25 e 29 anos, $16 \%$ entre 30 e 39 anos, $12 \%$ entre 40 e 49 anos, $11 \%$ entre 50 e 64 anos e $6,3 \%$ acima de 64 anos. Quanto ao sexo, $48,4 \%$ são do sexo masculino e $51,6 \%$ do sexo feminino.

Como mencionado acima, a taxa de crescimento demográfico do município vem declinando nas últimas três décadas, sendo que no período $1991 / 2000$ foi de $0,88 \%$ ao ano. A taxa de migração foi negativa durante a década de 1990.

A densidade populacional municipal é bastante elevada: 7.024 habitantes por quilômetro quadrado, mas sua distribuição é bastante desigual no espaço.

Apesar da recente descentralização industrial, a cidade ainda concentra 47.221 indústrias. Entretanto, aumento na produtividade industrial foi responsável pela dissociação entre aumento da produção industrial e empregos. Assim, a cidade apresenta elevada taxa de desemprego (17,9\%), que é bastante séria por causa do elevado número de pessoas envolvidas (cerca de 1 milhão), pela relativamente alta qualificação dos desempregados e pela falta de oportunidade de emprego para os jovens.

Com relação aos demais municipios brasileiros (5.507), encontra-se na $63^{a}$ posição $(0,841)$ pelo Índice de Desenvolvimento Humano do Município de São Paulo (IDHM) ${ }^{21}$ (PMSP 2004b), e uma renda per capita municipal, em 2004, de US\$ 4.934 (PMSP, 2004a).

Em que pese toda esta riqueza, um em cada 10 de seus moradores vive em moradias precárias - favelas, bairros precários ou nas ruas. Há 2.081 favelas no municipio, onde vivem cerca de 1.160 .000 pessoas.

\footnotetext{
${ }^{21}$ O Indice de Desenvolvimento Humano do Município de São Paulo (IDHM) é uma adaptação do Indice de Desenvolvimento Humano criado pela ONU, realizada pela Secretaria de Desenvolvimento, Trabalho e Solidariedade da Prefeitura do Município de São Paulo, com o objetivo de comparar o grau de desenvolvimento humano entre distritos do município de São Paulo. É composto pelos indicadores de Taxa de Mortalidade Infantil, Porcentagem da População Alfabetizada e Rendimento dos Chefes de Família. Estes indicadores são transformados em índices, que somados formam o IDHM. Ele varia de zero (piores condições de desenvolvimento) a um (melhores condições de desenvolvimento). (PMSP 2004)
} 
O Sistema Único de Saúde, no municipio de São Paulo, só foi implantado no ano 2000. Desde então, a administração municipal recebe recursos do governo federal para administrar o sistema de saúde. $O$ número de Unidades de Saúde passou de 74 a 563 no periodo 2000 a 2004 (PMSP, 2004b). Por conta desta transição e da falta de recursos financeiros, de infra-estrutura e de recursos humanos, as questōes de saúde pública são graves na cidade.

As cinco principais causas de óbitos no município são: doenças isquêmicas do coração (13\%); doenças cérebro-vasculares $(8,1 \%)$; homicídios $(7,6 \%)$; pneumonias $(5,9 \%)$ e bronquite, asma e enfisema $(3,9 \%)$ (Sistema Único de Saúde, 2004). Há variações segundo as faixas etárias e o sexo, mas pode-se verificar que a violência tem um papel importante nas questões de saúde pública e do ambiente sócio-ambiental do municipio.

Para se aprofundar a análise da distribuição espacial do crime no municipio de São Paulo, foram selecionados 4 distritos policiais: Capão Redondo, Morumbi, Santo Amaro e Sé.

A seleção destes distritos se deu por apresentarem características diferenciadas em termos de condições sócio-econômicas, demográficas, IDHM índice de desenvolvimento humano e de distribuição das diferentes modalidades de crime.

\section{- Capão Redondo}

O distrito policial de Capão Redondo possui limites próximos aos limites do distrito municipal de Capão Redondo. Localiza-se no sudoeste da área urbanizada de São Paulo, fazendo limite a leste com o Jardim Ângela, um dos distritos com piores indicadores sócio-econômicos do município, e a oeste com o município de Embú. A população do distrito era de 242.368 , de acordo com o censo de 2000. Apresentou elevadas taxas de crescimento demográfico na década 1991-2000, quando a população aumentou 25\% (IBGE, 2000). O bairro apresenta uma ocupação mais recente e muitas áreas não consolidadas e mal servidas por serviços públicos e infra-estrutura. 
O distrito está inserido na sub-prefeitura de Campo Limpo. Estudo realizado por Pedroso (2003) calculou o IDHM das sub-prefeituras e dos setores censitários do município de São Paulo. Aquela área apresentou IDHM 0,70 a 0,80 , classificado como médio. $O$ setor sul da área da sub-prefeitura, onde se localiza Capão Redondo, apresenta vários setores censitários com IDHM baixo $(0,50$ a 0,70$)$. Nestes distritos a renda média mensal per capita era de $R \$ 144,69$ e a média de anos de estudo era de 5,5 anos, enquanto na média da sub-prefeitura era de 6,9 anos. A taxa de analfabetismo era de $6 \%$ e a expectativa de vida ao nascer 75,9 anos (PEDROSO, 2003).

- Morumbi

O distrito policial do Morumbi localiza-se, também, a sudoeste da área urbana, em área de ocupação mais consolidada, mas com alguns vazios urbanos e várias favelas em seu interior e em seus limites. Em 2000, o distrito municipal do Morumbi continha 33.891 habitantes e havia apresentado crescimento demográfico negativo de $-15 \%$, no período 1991-2000 (IBGE, 2000).

O distrito está inserido na sub-prefeitura de Butantã, que apresenta em média IDHM classificado como muito alto $(0,90$ a 1,00$)$. Possui um setor mais rico a leste, cuja renda mensal per capita variava de $\mathrm{R} \$ 860,64$ a $\mathrm{R} \$ 2.357,03 \mathrm{e}$ cuja média de anos de estudo ia de 11,3 a 13,5 (PEDROSO, 2003).

Entretanto, no setor mais a oeste, há setores censitários de baixo $e$ médio IDHM. Neles, os moradores possuem de 4,7 a 7 anos de estudo a a renda per capita mensal varia de $\mathrm{R} \$ 92,80$ a $\mathrm{R} \$ 265,23$.

Portanto, a renda dos setores de IDHM muito alto chega a ser 25 vezes superior à da população dos setores de IDHM mais baixos. O número de anos de estudo chega a ser 3 vezes superior. Caracteriza-se então esta área por extrema desigualdade sócio-econômica e má distribuição de renda. 
- Santo Amaro

O distrito policial situa-se no centro-sul da cidade, em área já consolidada. Abriga o mais importante parque industrial do município. Entretanto, tem passado por mudanças na sua estrutura econômica com saída de algumas indústrias $e$ instalação de empreendimentos comerciais e de serviços de grande porte. Além disso, possui um expressivo centro local e regional de comércio de rua e um terminal de transporte de ônibus com grande volume de passageiros, pois nele se fazem transferências de linhas tronco, que vêm do centro da cidade, a linhas de bairros dormitórios periféricos populares em áreas de ocupação mais recente, ainda não totalmente consolidadas e com infra-estrutura insuficiente.

Em 2000, o distrito possuía 59.758 habitantes, registrando uma perda de $20 \%$ de sua população no período 1991-2000 (IBGE, 2000).

O distrito está inserido na sub-prefeitura de mesmo nome (Santo Amaro), caracterizada por alto $\operatorname{IDHM}(0,85)$, na quarta posição dentre as sub-prefeituras municipais. A renda per capita mensal da sub-prefeitura era de R\$924,36. A expectativa de vida era de 76,3 anos e seus moradores têm, em média 10 anos de estudo. Somente $1,2 \%$ de seus habitantes são analfabetos (PEDROSO, 2003).

- Sé

O distrito policial da Sé situa-se no distrito municipal e na sub-prefeitura de mesmo nome (Sé). Localiza-se bem no centro da mancha urbana e constitui o antigo centro de negócios do município. Hoje, em função do deslocamento do centro de negócios para outras regiões mais valorizadas da cidade (Av. Paulista, Av. Faria Lima e Av. Luiz C. Berrini, dentre outras), há muitos imóveis comerciais vazios na área e uma reduzida população residente. Em 2000, moravam 20.106 pessoas no distrito da Sé. Entretanto, em que pese ser servido por excelente infra-estrutura, o distrito continua a perder moradores. Entre 1991 e 2000 sua população residente reduziu-se em $26 \%$. 
Por outro lado, a área apresenta expressiva população flutuante, uma vez que a oferta de empregos aí é das mais elevadas da cidade, além de apresentar intenso e diversificado comércio de rua, que atrai compradores de todo pais.

A área da sub-prefeitura da Sé, onde fica o distrito, é caracterizada por alto IDHM $(0,84)$, na quinta posição do município. A renda per capita mensal média é de $\mathrm{R} \$ 800,00$, a expectativa de vida é de 76,7 anos, a média de anos de estudo de seus moradores é 10,4 anos e a taxa de analfabetismo é de 1,7\% (PEDROSO, 2003). Já na área mais específica do distrito da Sé, o IDHM é médio $(0,70$ a 0,80$)$, a expectativa de vida cai para 73,9 anos, a média de anos de estudo é de apenas 7,6 anos e o rendimento médio mensal per capita é de R\$ 300,00 (PEDROSO, 2003).

\subsubsection{Bases de Dados}

\subsubsection{Dados Alfanuméricos}

Para a elaboração deste trabalho foram utilizadas bases de dados de origem alfanumérica em formato $\mathrm{DBF}^{22}$, agrupados em variáveis de duas naturezas: quantitativas (de posição numa escala) e qualitativas (de alocação numa categoria).

As variáveis quantitativas tratadas são as provenientes das bases de dados do sistema INFOCRIM ${ }^{23}$ e Disque Denúncia ${ }^{24}$ da Secretaria de Segurança Pública do Estado de São Paulo.

As variáveis qualitativas utilizadas pelo trabalho foram as categorias sócio-econômicas, obtidas a partir do Censo Demográfico do IBGE, e

\footnotetext{
${ }^{22}$ Formato para base de dados.

${ }^{23}$ O INFOCRIM é um sistema de visualização de informações criminais registradas pela polícia, e desenvolvido pela Secretaria de Segurança Pública do Estado de São Paulo para acompanhamento e mapeamento do crime.

${ }^{24}$ O Disque Denúncia é um canal de contato que permite a população fazer denúncias via telefone, sem se identificar, para a Secretaria de Segurança Pública do Estado.
} 
elaboradas pelo Instituto UNIEMP (Projeto para a organização de um Centro de Análise Criminal na Secretaria de Segurança Pública de São Paulo) para a Secretaria de Segurança Pública do Estado de São Paulo.

Com efeito, buscou-se trabalhar com um leque relativamente reduzido de variáveis para cada uma das dimensões consideradas, mas que abrangessem o município como um todo.

O Quadro 3 demonstra as principais características das bases de dados utilizados, de acordo com as instituições responsáveis e atualização.

Quadro 3. Principais Caracteristicas das Bases de Dados alfanuméricos.

\begin{tabular}{|c|c|c|c|c|c|}
\hline $\begin{array}{l}\text { BASE DE } \\
\text { DADO }\end{array}$ & ATUALIZAÇĀO & FONTE & $\begin{array}{l}\text { UNIDADE DE } \\
\text { REGISTRO }\end{array}$ & $\begin{array}{l}\text { UNIDADE } \\
\text { ESPACIAL DE } \\
\text { REFERÊNCIA }\end{array}$ & $\begin{array}{l}\text { PERIOODO } \\
\text { UTILIZADO }\end{array}$ \\
\hline INFOCRIM & Diária & SSP-SP & \begin{tabular}{|ll} 
Boletim de & de \\
Ocorrência $^{25}$
\end{tabular} & $\begin{array}{ll}\text { Latitude } & \mathrm{e} \\
\text { Longitude } & \end{array}$ & $\begin{array}{ll}01 / 2001 & a \\
03 / 2004 & \end{array}$ \\
\hline $\begin{array}{l}\text { Disque } \\
\text { Denúncia }\end{array}$ & Diária & SSP-SP & Denúncia & Endereço & $\begin{array}{ll}10 / 2000 & a \\
04 / 2003 & \end{array}$ \\
\hline $\begin{array}{l}\text { Categorias } \\
\text { sócio- } \\
\text { econômicas }\end{array}$ & - & UNIEMP & Cluster & Setor Censitário & 2000 \\
\hline
\end{tabular}

Fonte: Elaborado pela autora.

\subsubsection{Dados Gráficos}

Os dados de origem gráfica (vetorial), utilizados neste estudo, foram os disponibilizados pela empresa Multispectral Ltda, pelo Centro de Estudos da Metrópole (CEM), pelo IBGE e pela Secretaria de Segurança Pública do Estado de São Paulo (Quadro 4).

${ }^{25}$ O Boletim de Ocorrência (BO) é um documento que formaliza as notícias de infração penal ou de fatos que devam ficar registrados em documento público. 
As bases de dados gráficos selecionados, em formato digital, apresentaram os quatro componentes principais necessários à realização desta pesquisa: posição geográfica, atributos geométricos, tempo e topologia.

Quadro 4 - Principais Caracteristicas das Bases de Dados Gráficos.

\begin{tabular}{|c|c|c|c|c|c|}
\hline BASE DE DADO & FORMATO & FONTE & $\begin{array}{l}\text { SISTEMA DE } \\
\text { PROJEÇÃO }\end{array}$ & \begin{tabular}{|l|} 
ELEMENTO \\
VETORIAL
\end{tabular} & \begin{tabular}{|l} 
PERIODO \\
DE ORIGEM
\end{tabular} \\
\hline Distrito Policial & $\begin{array}{l}\text { TAB } \\
\text { (Maplnfo) }\end{array}$ & SSP-SP & $\begin{array}{l}\text { UTM I Córrego } \\
\text { Alegre }\end{array}$ & polígono & 2000 \\
\hline $\begin{array}{l}\text { Sede de Delegacia } \\
\text { de Polícia e } \\
\text { Comunitária de } \\
\text { Segurança }\end{array}$ & $\begin{array}{l}\text { TAB } \\
\text { (Maplnfo) }\end{array}$ & SSP-SP & $\begin{array}{l}\text { UTM / Córrego } \\
\text { Alegre }\end{array}$ & ponto & 2000 \\
\hline $\begin{array}{l}\text { Rede de Saúde, } \\
\text { Rede de Ensino, } \\
\text { Agência Bancária e } \\
\text { Shopping }\end{array}$ & $\begin{array}{l}\text { TAB } \\
\text { (Maplnfo) }\end{array}$ & SSP-SP & $\begin{array}{l}\text { UTM / Córrego } \\
\text { Alegre }\end{array}$ & ponto & 2004 \\
\hline $\begin{array}{l}\text { Cadastro Central } \\
\text { de Empresas } \\
\text { (CEMPRE) }\end{array}$ & $\begin{array}{l}\text { SHP } \\
\text { (ArcView) }\end{array}$ & CEM (IBGE) & UTM / SAD 69 & ponto & 2000 \\
\hline Favelas & $\begin{array}{l}\text { SHP } \\
\text { (ArcView) }\end{array}$ & CEM & UTM / SAD 69 & poligono & 2001 \\
\hline $\begin{array}{ll}\text { Limite } & \text { de } \\
\text { municipios } & \end{array}$ & $\begin{array}{l}\text { TAB } \\
\text { (Maplnfo) }\end{array}$ & Multispectral & $\begin{array}{l}\text { UTM / Córrego } \\
\text { Alegre }\end{array}$ & polígono & 1997 \\
\hline 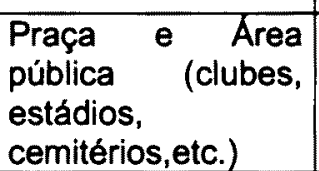 & \begin{tabular}{|l} 
TAB \\
(Maplnfo)
\end{tabular} & Multispectral & $\begin{array}{l}\text { UTM / Córrego } \\
\text { Alegre }\end{array}$ & polígono & 2001 \\
\hline $\begin{array}{lr}\text { Terminal } & \text { de } \\
\text { Onibus, } & \text { Estação } \\
\text { de Trem e Estação } \\
\text { de Metró }\end{array}$ & $\begin{array}{l}\text { TAB } \\
\text { (Maplnfo) }\end{array}$ & Multispectral & $\begin{array}{l}\text { UTM / Córrego } \\
\text { Alegre }\end{array}$ & ponto & 2004 \\
\hline $\begin{array}{l}\text { Rua, Via Principal, } \\
\text { Estada/Rodovia e } \\
\text { Túnel/Viaduto }\end{array}$ & $\begin{array}{l}\text { TAB } \\
\text { (Maplnfo) }\end{array}$ & Multispectral & $\begin{array}{l}\text { UTM I Córrego } \\
\text { Alegre }\end{array}$ & linha & 2004 \\
\hline $\begin{array}{l}\text { Rio e Córrego } 1 \\
\text { Lago }\end{array}$ & $\begin{array}{l}\text { TAB } \\
\text { (Maplnfo) }\end{array}$ & Multispectral & $\begin{array}{l}\text { UTM I Córrego } \\
\text { Alegre }\end{array}$ & \begin{tabular}{|l|} 
Linha \\
poligono
\end{tabular} & 2004 \\
\hline $\begin{array}{l}\text { Censo } \\
\text { Demografico }\end{array}$ & $\begin{array}{l}\text { TAB } \\
\text { (Maplnfo) }\end{array}$ & IBGE & UTM / SAD 69 & polígono & 2000 \\
\hline
\end{tabular}

Fonte: Elaborado pela autora. 


\subsubsection{Ferramentas}

\subsubsection{Equipamentos}

Para a viabilização do trabalho proposto foram utilizados os seguintes equipamentos (Hardware) de informáticas:

- Computador pessoal (PC) com processador Pentium III 933Mhz, 256 Mbytes de memória RAM, disco rígido de 40 Gbytes, unidade de disco flexível de $3 \frac{1}{2}$ polegadas, unidade de leitura e gravação de CDROM, placa de vídeo com 32 Mbytes, teclado e mouse óptico;

- Monitor SVGA de 17 polegadas;

- Impressora jato de tinta colorida, com resolução de 1200 pontos/polegada;

\subsubsection{Programas}

Além dos equipamentos, anteriormente citados, houve a necessidade do uso de programas (Software) para o manejo das informações gráficas e alfanuméricas, que possibilitaram a criação, manipulação e 0 acesso aos dados.

Os programas, em sistema de operação DOSMINDOWS, utilizados foram:

- MAPINFO 7.5: permite a integração dos arquivos de dados gráficos (vetoriais e rasters) com os alfanuméricos;

- SPSS $^{26}$ 11.0: possibilita o tratamento dos bancos de dados alfanuméricos.

Os dados alfanuméricos foram tratados em conjunto com o software SPSS e MapInfo. Os trabalhos estatísticos foram elaborados pelo SPSS, as junções de dados alfanuméricos com os dados gráficos e a elaboração dos produtos cartográficos, pelo Maplnfo.

${ }^{26}$ SPSS - Statistical Package for the Social Sciences. 
A escolha destes produtos justificou-se pelo fato de serem compatíveis aos objetivos propostos por esta pesquisa, de modo que os dados coletados (gráficos e alfanuméricos) puderam ser processados com grande eficiência.

\subsection{Métodos}

\subsubsection{Coleta dos Dados}

Os dados gráficos e não gráficos utilizados neste estudo são de origem secundária, e foram disponibilizados de forma direta e indireta por instituições públicas e privadas.

A coleta dos dados foi efetuada de forma direta através de visita a Secretaria de Segurança Pública do Estado de São Paulo; ao Centro de Estudos da Metrópole; a empresa Multispectral; ao Instituto Brasileiro de Geografia e Estatística (IBGE), e a bibliotecas por meio da consulta de livros e artigos, referentes ao tema.

E de forma indireta por meio de relatórios técnicos produzidos pela UNIEMP e pela Prefeitura do Município de São Paulo.

As bases de dados dos Boletins de Ocorrência, do Disque Denúncia, das categorias sócio-econômicas, além de algumas bases gráficas (Distrito Policial, Sede de Delegacia de Polícia, Base Comunitária de Segurança, Rede de Saúde e Ensino, Agências Bancárias e Shoppings), foram obtidos na Secretaria de Segurança Pública do Estado de São Paulo; o Cadastro Central de Empresas e a base gráfica de favelas do município de São Paulo foram coletadas no Centro de Estudos da Metrópole (CEM), sediado no CEBRAP; as bases gráficas oriundas de cartas topográficas digitalizadas (limites municipais, áreas verdes, hidrografia principal e eixos de logradouro), e os pontos referentes aos terminais e estações de transporte urbano foram adquiridos pela empresa Multispectral Ltda, e a base de dados gráficos e alfanuméricos, com as informações do último censo demográfico da cidade de São Paulo, foi obtida através do Instituto Brasileiro de Geografia e Estatística (IBGE). 


\subsubsection{Investigação dos Dados}

Para a elaboração de um estudo sobre violência no ambiente urbano, a partir da aplicação de técnicas dos Sistemas de Informação Geográfica, faz-se necessária à investigação das características e cobertura dos dados para a implementação da metodologia.

Tendo em vista que o desenvolvimento de um SIG envolve a integração de dados de múltiplas fontes, com precisões, escalas, estruturas geométricas, projeções e resoluções espaciais distintos, o conhecimento da qualidade dos dados tratados é primordial à implementação do sistema e tomada de decisões válidas.

As bases de dados, gráficos e não gráficos, coletados, foram pesquisadas a partir da aplicação de ferramentas disponiveis nos softwares Maplnfo e SPSS. Esta análise exploratória inicial se deu, nas bases de dados não gráficos, através da geração de tabelas de freqüência simples, análise univariada com medidas de associação e teste de significância, verificação da abrangência dos dados, e qualidade dos registros; e nas bases de dados gráficos por meio de investigação de seus sistemas de projeção, qualidade de registro e de vetorização, abrangência dos dados e atualização das informações.

O levantamento sobre as característica das bases de dados não gráficos (alfanuméricos) coletados, encontra-se descrito a seguir:

\section{- INFOCRIM}

Oficialmente, as estatísticas da Secretaria de Segurança Pública do Estado de São Paulo estão baseadas na Resolução 160/01 e não no sistema INFOCRIM, que é antes uma ferramenta de mapeamento de investigação criminal. A primeira diferença é de cobertura: a Resolução 160/01 coleta informações mensais de todos os Distritos Policiais do Estado enquanto o 
INFOCRIM traz dados apenas dos 42 municípios onde o sistema está em funcionamento no momento. Regra geral, ambas as fontes, revelam as mesmas tendências de criminalidade, embora os números nem sempre coincidam, por diversos motivos:

- Alteração da natureza durante o inquérito com a morte da vítima;

- Alteração da natureza no BO complementar,

- Área de registro diferente da área de apuração.

A base de dados alfanuméricos de Boletins de Ocorrência do INFORCRIM, referente ao periodo de 01/2001 a 03/2004, continham, originalmente as seguintes variáveis:

- Natureza do crime;

- Data e hora da ocorrência;

- Número do Boletim de Ocorrência;

- Distrito Policial e Seccional pertencente ao local do crime;

- Coordenadas cartesianas do local do crime, e

- Classificação jurídica das mortes.

A partir desta análise preliminar, pode-se observar que a base de BO's fornecida pela Secretaria de Segurança Pública do Estado de São Paulo (SSPSP) apresentava os seguintes registros (Quadro 5):

Quadro 5 - Registros por ano.

\begin{tabular}{|l|c|}
\hline ANO & $N^{\circ}$ DE BO's \\
\hline 2001,00 & 746.599 \\
\hline 2002,00 & 762.945 \\
\hline 2003,00 & 1.098 .528 \\
\hline 2004,00 & 518.475 \\
\hline TOTAL & 3.126 .547 \\
\hline
\end{tabular}

Fonte: SSP-SP. Elaborado pela autora. 
A base de dados coletados apresentava um total 480 naturezas de ocorrência, que podem ser observadas, com suas respectivas freqüências, no Anexo A2.

Num primeiro momento, foram selecionados os seguintes grupos de naturezas de ocorrências:

1. Estupro

2. Furto de cargas

3. Furto de estabelecimentos

4. Furto outros

5. Furto de pessoas

6. Furto de residências

7. Furto de transeuntes

8. Furto de transporte coletivo

9. Furto de veículos

10. Homicídio doloso

11. Roubo de cargas

12. Roubo de estabelecimentos

13. Roubo seguido de morte ou lesão grave

14. Roubo outros

15. Roubo de pessoas

16. Roubo de residências

17. Roubo de transeuntes

18. Roubo de transporte coletivo

19. Roubo de veículos

20. Seqüestro

21. Tráfico de entorpecente

Os dados utilizados nessa etapa foram extraídos do INFOCRIM e o período de ocorrências considerado foi de janeiro de 2001 a agosto de 2003, 
totalizando 32 meses. Esses grupos foram escolhidos de maneira a ter uma boa desagregação em termos de naturezas das ocorrências, e ao mesmo tempo ter um número razoável de ocorrências em cada categoria e para cada DP ${ }^{27}$.

A categoria "furto pessoas" corresponde a uma agregação das naturezas de ocorrências: furto de celular/bip/"pager" e furto de documentos. O mesmo tipo de observação vale para a categoria "roubo pessoas". As categorias "roubos estabelecimentos" e "furtos estabelecimentos" correspondem a roubos e furtos em estabelecimentos de ensinos, estabelecimentos bancários e estabelecimentos outros. A categoria "tráfico de entorpecentes" corresponde a tráfico de maconha, tráfico de psicotrópicos e tráfico de outros.

Num segundo momento deste estudo, foram selecionados os seguintes grupos de natureza seguido de seus respectivos números de ocorrência:

Quadro 6 - Número de Ocorrências por Natureza.

\begin{tabular}{|l|c|}
\hline Tipo de Crime & N$^{\circ}$ DE BO's \\
\hline HOMICIDIO & \\
\hline TENTATIVA DE HOMICÍDIO & 7.445 \\
\hline LATROCINIIO & 5.553 \\
\hline ROUBO A RESIDÉNCIA & 88 \\
\hline ROUBO A TRANSEUNTE & 5.549 \\
\hline ROUBO DE VEICULO & 57.761 \\
\hline ROUBO A INTERIOR DE VEICULO & 71.331 \\
\hline TOTAL & 18.561 \\
\hline
\end{tabular}

Fonte: SSP-SP. Elaborado pela autora.

\footnotetext{
${ }^{27}$ O Distrito Policial (DP) representa a divisão territorial das áreas de atuação das Policias Civil e Militar.

${ }^{28}$ A categoria "Homicídio" corresponde a todas as naturezas referentes a Homicídios Doloso e Qualificado.
} 
Os dados utilizados nessa etapa foram extraídos do INFOCRIM e o período de ocorrências considerado foi de abril de 2003 a março de 2004, totalizando 12 meses.

A escolha destes grupos se justificou, principalmente, pela alta violência empregada (Homicídio, Latrocínio, Tentativa de Homicídio e Estupro), pelo grande número de boletins registrados na cidade de São Paulo para o período selecionado (Roubo à Residência, Transeunte, Veículo e Interior de Veículo), e pela notável heterogeneidade na distribuição espacial dos mesmos.

- Disque Denúncia

O arquivo de dados alfanumérico do Disque Denúncia, com 36.981 registros $^{29}$ em formato SPSS, consiste, em sua maioria, da cidade de São Paulo, sendo que há também alguns registros referentes a cidades da região metropolitana.

A base de dados do Disque Denúncia, com informações entre Outubro de 2000 e Abril de 2003 foi considerada para a integração com os dados do INFOCRIM, para a verificação de possiveis relações entre as informações.

Mas a coleta das informações, via telefone, nem sempre é completa, há ausência de alguns dados nos campos disponiveis para o preenchimento das informações pelo operador do sistema do Disque Denúncia. Dessa forma uma característica comum nessa base de dados é a falta de várias informações em muitos registros. Outra característica comum a esta base é a localização aproximada da ocorrência alvo da denúncia. Embora o indicativo da localização sempre esteja disponível, muitas vezes ele é vago e incompleto, ou escrito de forma incorreta, o que torna difícil sua localização na base de eixos de logradouro.

\footnotetext{
${ }^{29}$ Para cada denúncia feita, são gravadas informações sobre o tipo de denúncia, a data da ligação, o local da denúncia, e outras variáveis, como CEP do local, Distrito Policial, Bairro, Cidade, código do tipo de denúncia e o número da denúncia no mês.
} 
A inexistência de qualquer controle para entrada dos dados faz com que os campos referentes à localização não estejam padronizados, isso tornou impraticável a geocodificação dos dados, sendo em muitos casos mesmo impossível, e a mesma, se feita, pode estar sujeita a grandes margens de erro.

Outras informações importantes que constam do arquivo de dados do Disque Denúncia são o número do distrito policial referente ao local do fato denunciado (presente em apenas $58 \%$ dos registros), o mês e ano da denúncia, o tipo da ocorrência que deu origem à denúncia, e outros campos ligados ao local da ocorrência, como CEP, número, complemento, que aparecem vazios em muitos casos.

Desta forma, considerou-se inviável a utilização de tal base no estudo em questão.

- Categorias Sócio-econômicas

Como a análise criminal não passa apenas pela determinação de pontos de concentração do crime, mas também pela caracterização de áreas com perfil semelhantes para o direcionamento de ações preventivas, torna-se interessante o trabalho com áreas para as quais pode-se conhecer as características sócioeconômicas. As menores áreas para as quais existe tal informação são os setores censitários do $\mathrm{IBGE}^{30}$, onde, no município de São Paulo, possuem em média 220 domicilios.

As categoria sócio-econômicas coletadas foram elaboradas pelo Instituto UNIEMP e disponibilizadas pela Secretaria de Segurança Pública do Estado de São Paulo.

As áreas homogêneas foram criadas para o município de São Paulo, a partir do uso de variáveis censitárias coletadas do Censo Demográfico do IBGE para o ano 2000.

\footnotetext{
${ }^{30}$ O Censo Demográfico, realizado pelo IBGE a cada 10 anos, divide os municípios em células, chamadas de setores censitários, que apresentam diferentes tamanhos físicos, mas uma média, aproximada, de 300 domicílios. O município de São Paulo possui um total de 13.278 setores, ou seja, uma média de 228 domicílios por setor. (IBGE, 2000)
} 
A existência de informações confiáveis para os setores censitários faz com que análises por esta unidade tenham boas propriedades estatísticas. Além disso, o setor censitário é uma unidade de área de tamanho padronizado, com definição clara para qualquer localidade no país.

A criação de áreas homogêneas consiste em agrupar setores censitários com perfis semelhantes. Isso pode ser feito de várias formas a partir da aplicação de técnicas estatísticas de Análise de Agrupamento, descritas no próximo item deste capítulo.

Para Análise de Agrupamento aplicada no município de São Paulo, foi obtida a seguinte distribuição de variáveis por grupo homogêneo, conforme demonstra a Tabela 1. 
Tabela 1- Variáveis censitárias por grupos homogêneos.

\begin{tabular}{|c|c|c|c|c|c|c|c|c|}
\hline Algumas estatísticas descritivas & 1 & 2 & 3 & 4 & 5 & 6 & 7 & 8 \\
\hline Número total de domicilios & 153.668 & 668.528 & 1.116 .952 & 655.157 & 36.956 & 119.849 & 235.914 & 52.074 \\
\hline Número total de residentes & 570.145 & 2.607 .589 & 3.974 .618 & 2.078 .135 & 83.514 & 277.511 & 677.996 & 164.737 \\
\hline Proporção de responsáveis mulheres & $24,1 \%$ & $26,3 \%$ & $27,9 \%$ & $30,3 \%$ & $42,4 \%$ & $46,0 \%$ & $32,6 \%$ & $25,9 \%$ \\
\hline Proporção de renda das mulheres & $17,4 \%$ & $18,6 \%$ & $18,6 \%$ & $19,6 \%$ & $34,0 \%$ & $36,4 \%$ & $22,0 \%$ & $16,5 \%$ \\
\hline Proporção de domicilios com abastecimento de água & $69,2 \%$ & $98,9 \%$ & $99,4 \%$ & $97,0 \%$ & $93,8 \%$ & $94,1 \%$ & $98,6 \%$ & $99,1 \%$ \\
\hline Proporção de domicílios com coleta de lixo & $78,6 \%$ & $99,0 \%$ & $99,5 \%$ & $97,1 \%$ & $93,8 \%$ & $94,3 \%$ & $98,7 \%$ & $99,3 \%$ \\
\hline Proporção de domicilios com sistema de esgoto & $48,5 \%$ & $73,5 \%$ & $97,1 \%$ & $96,3 \%$ & $93,6 \%$ & $94,1 \%$ & $98,4 \%$ & $99,1 \%$ \\
\hline Proporção de domicilios com 3 banheiros & $1,8 \%$ & $1,2 \%$ & $3,6 \%$ & $10,3 \%$ & $1,8 \%$ & $6.7 \%$ & $34,4 \%$ & $33,9 \%$ \\
\hline Proporção de domicilios com 4 ou mais banheiros & $0,6 \%$ & $0,2 \%$ & $1,0 \%$ & $4,6 \%$ & $0,4 \%$ & $1,6 \%$ & $14,7 \%$ & $44,2 \%$ \\
\hline Proporção de domicílios com 1 ou 2 moradores & $20,6 \%$ & $21,1 \%$ & $26,7 \%$ & $34,1 \%$ & $61,0 \%$ & $59,1 \%$ & $44,1 \%$ & $37,4 \%$ \\
\hline Proporção de domicilios com 3 ou 4 moradores & $41,6 \%$ & $47,3 \%$ & $48,8 \%$ & $45,8 \%$ & $26,9 \%$ & $28,2 \%$ & $42,1 \%$ & $43,9 \%$ \\
\hline Proporção de domicilios com mais de 4 moradores & $37,8 \%$ & $31,7 \%$ & $24,5 \%$ & $20,1 \%$ & $12,1 \%$ & $12,7 \%$ & $13,8 \%$ & $18,7 \%$ \\
\hline Número de filhos por morador & 0,447 & 0,463 & 0,419 & 0,367 & 0,237 & 0,254 & 0,335 & 0,349 \\
\hline Proporção de mulheres por morador & $50,3 \%$ & $50,9 \%$ & $52,1 \%$ & $53,5 \%$ & $52,5 \%$ & $56,3 \%$ & $55,1 \%$ & $55,1 \%$ \\
\hline Proporçāo de pessoas com até 18 anos & $41,3 \%$ & $41,9 \%$ & $32,6 \%$ & $24,6 \%$ & $20,8 \%$ & $17,7 \%$ & $20,8 \%$ & $21,4 \%$ \\
\hline Proporção de pessoas entre 19 e 34 anos & $31,2 \%$ & $31,3 \%$ & $29,4 \%$ & $26,3 \%$ & $37,8 \%$ & $29,6 \%$ & $26,5 \%$ & $26,1 \%$ \\
\hline Proporção de pessoas com mais de 54 anos & $6,6 \%$ & $5,6 \%$ & $12,0 \%$ & $20,0 \%$ & $11,6 \%$ & $23,2 \%$ & $21,5 \%$ & $21,1 \%$ \\
\hline Proporção de responsáveis com primeiro grau & $66,2 \%$ & $68,2 \%$ & $54,4 \%$ & $34,1 \%$ & $22,9 \%$ & $21,3 \%$ & $11,6 \%$ & $8,9 \%$ \\
\hline Proporçāo de responsáveis com segundo grau & $17,2 \%$ & $17.1 \%$ & $30,2 \%$ & $33,6 \%$ & $30,9 \%$ & $31,7 \%$ & $23,5 \%$ & $19,4 \%$ \\
\hline Proporção de responsáveis com nivel superior & $4,2 \%$ & $2,2 \%$ & $8,5 \%$ & $28,3 \%$ & $41,6 \%$ & $42,5 \%$ & $58,4 \%$ & $62,1 \%$ \\
\hline Proporçāo de responsáveis com pós-graduação & $0,1 \%$ & $0,0 \%$ & $0,2 \%$ & $1,0 \%$ & $2,8 \%$ & $3,1 \%$ & $5,9 \%$ & $9,1 \%$ \\
\hline Proporção de apartamentos & $6,3 \%$ & $9,5 \%$ & $14,7 \%$ & $26,6 \%$ & $85,2 \%$ & $79,0 \%$ & $73,8 \%$ & $75,7 \%$ \\
\hline Renda média por domicílio & $\mathrm{R} \$ 472,46$ & $\mathbf{R} \$ 436,24$ & $\mathrm{R} \$ 782,02$ & $\mathrm{R} \$ 1.618,97$ & $\mathrm{R} \$ 1.730,06$ & $\mathrm{R} \$ 1.883,45$ & $\mathrm{R} \$ 4.117,00$ & $\mathrm{R} \$ 7.647,90$ \\
\hline Renda "per capita" & $R \$ 127,34$ & $\mathbf{R} \$ 111,84$ & $R \$ 219,76$ & $R \$ 510,40$ & $\mathbf{R} \$ 765,57$ & $\mathrm{R} \$ 813,41$ & $\mathrm{R} \$ 1.432,54$ & $\mathrm{R} \$ 2.417,53$ \\
\hline
\end{tabular}

Fonte: INSTITUTO UNIEMP, 2003.

${ }^{31}$ A renda "per capita" foi calculada com base apenas na renda mensal do responsável no domicilio. 
O levantamento sobre as característica das bases de dados gráficos coletados, encontram-se descritas a seguir:

- Distrito Policial

O arquivo, contendo a cartografia digital dos Distritos Policiais do município de São Paulo, em formato TAB (Maplnfo) encontra-se segmentada em 93 poligonos (Distritos Policiais).

No processo de investigação dos dados, observou-se deslocamentos nos limites dos polígonos com relação à base de eixos de logradouro coletada.

Desta forma, para a utilização da base com os limites territoriais dos DP's tiveram que ser corrigidos segundo a Resolução SSP- 245, de 26 julho de 2000 e adequados aos eixos de logradouro.

\section{- Cadastro Central de Empresas}

Esta base de dados contém informações cadastrais sobre as empresas formalmente constituídas, inscritas no Cadastro Nacional da Pessoa Jurídica (CNPJ), do Município de São Paulo. Estes dados apresentam informações sobre a empresa e seu endereço e foram georreferenciados pelo Centro de Estudos da Metrópole a partir do Cadastro Central de Empresas (CEMPRE), de 1999, do IBGE, publicado em 2000. A base possui um total de 22 variáveis e 452.816 registros, dos quais 3.495 não foram geocodificados.

O arquivo, que contém os dados geocodificados, apresenta deslocamentos nos registros, além de registros localizados em pontos como, por exemplo, o Túnel Ayrton Senna, o Lago do Ibirapuera, etc.

No processo de geocodificação das informações, foram aplicadas duas metodologias distintas. Num primeiro momento, foi utilizada a geocodificação sobre eixo de logradouro (linha), abrangendo cerca de 200.000 registros. Posteriormente, aplicou-se a geocodificação por CEP (polígono), onde, em alguns casos, foram inutilizados os três últimos dígitos do código. 
Com efeito, o uso da base de dados fornecida pelo CEM foi inviabilizado, pois apresentou deslocamentos oriundos da adoção de dois métodos de geocodificação, além de apresentar apenas os dados geograficamente localizados, 452.816 registros; os não geocodificados foram excluídos da base, cerca de 3.495 registros; conforme informações fornecidas pelo CEBRAP.

De acordo com o quadro obtido, uma alternativa sugerida para a solução do problema apresentado na base seria a nova geocodificação total do arquivo original (com aproximadamente 500.000 registros, segundo 0 IBGE), o que não seria possivel de se realizar neste estudo, devido ao tempo designado à elaboração de uma dissertação de Mestrado.

As demais bases de dados gráficos analisados encontraram-se dentro das Normas Técnicas da Cartografia Nacional e do padrão de qualidade necessário ao cumprimento dos objetivos propostos, neste estudo. São elas:

- Sede de Delegacia de Polícia:

- Base Comunitária de Segurança:

- Rede de Saúde:

- Rede de Ensino:

- Agência Bancária;

- Shoppingi

- Favelas:

- Limite de Municipios:

- Praça:

- Área Pública;

- Terminal de Ónibus:

- Estação de Trem:

- Estação de Metrô;

- Rua, Via Principal, Estada/Rodovia e Túnel/Viaduto;

- Rio e Córrego:

- Lago,e

- Censo Demográfico 


\subsubsection{Técnicas de Análise dos Dados}

\subsubsection{Análise de Agrupamento ("Cluster")}

Segundo Pereira (2001), uma das técnicas de análise multivariada ${ }^{32}$ é a Análise de Agrupamento ("Cluster"), onde as distâncias entre os objetos estudados, dentro do espaço multiplano constituido por eixos de todas as medidas (variáveis), são calculadas, e, a seguir, os objetos são agrupados conforme a proximidade entre eles.

A análise de agrupamentos é uma ferramenta poderosa de análise, que possibilita a identificação de padrões homogêneos em grandes bases de dados. Esse tipo de técnica é especialmente atraente quando as bases de informações contêm muitos registros e muitas variáveis.

Através de uma análise bem apurada, as técnicas de agrupamentos possibilitam transformar dados em informações que podem ser utilizadas para fins gerenciais de acompanhamento e de tomada de decisões.

Para um melhor entendimento da análise de agrupamentos, considere a Tabela 2, a seguir, contendo 60 registros, cada um caracterizado por duas variáveis, Variável 1 e Variável 2 (essas variáveis podem ser, por exemplo, a idade e a renda das 60 pessoas na amostra). Em uma primeira análise dos dados na tabela, é difícil notar algum padrão de relação para as duas variáveis observadas.

\footnotetext{
${ }^{32}$ A análise multivariada é, a rigor, qualquer abordagem analítica que considere o comportamento de muitas variáveis simultaneamente. (PEREIRA, 2001)
} 
Tabela 2 - Dados hipotéticos para ilustrar a análise de agrupamentos.

\begin{tabular}{lllllllll}
\hline $\begin{array}{l}\text { Regis- } \\
\text { tro }\end{array}$ & $\begin{array}{l}\text { Variavel } \\
1\end{array}$ & $\begin{array}{l}\text { Variavel } \\
2\end{array}$ & $\begin{array}{l}\text { Regis- } \\
\text { tro }\end{array}$ & $\begin{array}{l}\text { Variavel } \\
1\end{array}$ & $\begin{array}{l}\text { Variavel } \\
2\end{array}$ & $\begin{array}{l}\text { Regis- } \\
\text { tro }\end{array}$ & $\begin{array}{l}\text { Variavel } \\
1\end{array}$ & $\begin{array}{l}\text { Variavel } \\
2\end{array}$ \\
\hline 1 & 7,58 & 7,92 & 21 & 2,40 & 4,46 & 41 & 5,94 & 6,50 \\
2 & 6,48 & 6,74 & 22 & 1,04 & 2,50 & 42 & 5,55 & 7,04 \\
3 & 5,46 & 5,95 & 23 & 2,38 & 3,43 & 43 & 5,58 & 5,78 \\
4 & 5,42 & 5,55 & 24 & 2,86 & 3,29 & 44 & 7,84 & 7,79 \\
5 & 7,56 & 6,81 & 25 & 1,73 & 2,45 & 45 & 5,84 & 8,23 \\
6 & 5,17 & 8,94 & 26 & 3,18 & 4,52 & 46 & 7,68 & 7,72 \\
7 & 7,06 & 7,71 & 27 & 3,21 & 2,01 & 47 & 4,82 & 5,84 \\
8 & 6,52 & 5,06 & 28 & 1,78 & 4,28 & 48 & 6,27 & 6,68 \\
9 & 7,84 & 8,52 & 29 & 2,18 & 3,49 & 49 & 5,92 & 7,54 \\
10 & 7,08 & 7,12 & 30 & 2,00 & 2,66 & 50 & 1,19 & 4,60 \\
11 & 6,25 & 5,19 & 31 & 2,79 & 4,20 & 51 & 1,06 & 3,19 \\
12 & 5,52 & 5,83 & 32 & 1,66 & 2,70 & 52 & 1,59 & 4,04 \\
13 & 4,90 & 9,00 & 33 & 3,40 & 4,35 & 53 & 1,99 & 2,26 \\
14 & 5,60 & 8,12 & 34 & 2,57 & 3,37 & 54 & 2,14 & 2,01 \\
15 & 6,43 & 8,38 & 35 & 3,47 & 3,17 & 55 & 2,08 & 2,21 \\
16 & 6,03 & 7,01 & 36 & 2,88 & 3,69 & 56 & 2,79 & 3,60 \\
17 & 4,51 & 5,95 & 37 & 1,32 & 2,14 & 57 & 3,05 & 2,60 \\
18 & 6,98 & 5,20 & 38 & 2,82 & 2,75 & 58 & 1,56 & 2,27 \\
19 & 7,55 & 5,09 & 39 & 3,36 & 3,49 & 59 & 1,01 & 4,76 \\
20 & 5,38 & 7,49 & 40 & 3,09 & 2,03 & 60 & 1,18 & 3,66 \\
\hline
\end{tabular}

Fonte: Elaborado pela autora.

No entanto, pode-se obter uma melhor idéia da relação entre as variáveis 1 e 2 através de um gráfico de dispersão, conforme mostrado na Quadro 7, a seguir. Nesse gráfico, o eixo horizontal contém os valores para a variável 1, enquanto o eixo vertical contém os valores para a variável 2 . Pode-se observar que o conjunto das 60 observações pode ser divido em dois grupos bem separados no espaço. Em cada um desses grupos, os valores das variáveis 1 e 2 são relativamente próximos, quando comparados com os valores das variáveis 1 e 2 no outro grupo. Portanto, através de uma inspeção visual simples, é possível separar o conjunto de registros em 2 grupos homogêneos em termos de valores para as duas variáveis apresentadas. 
Quadro 7 - Gráfico hipotético de dispersão.

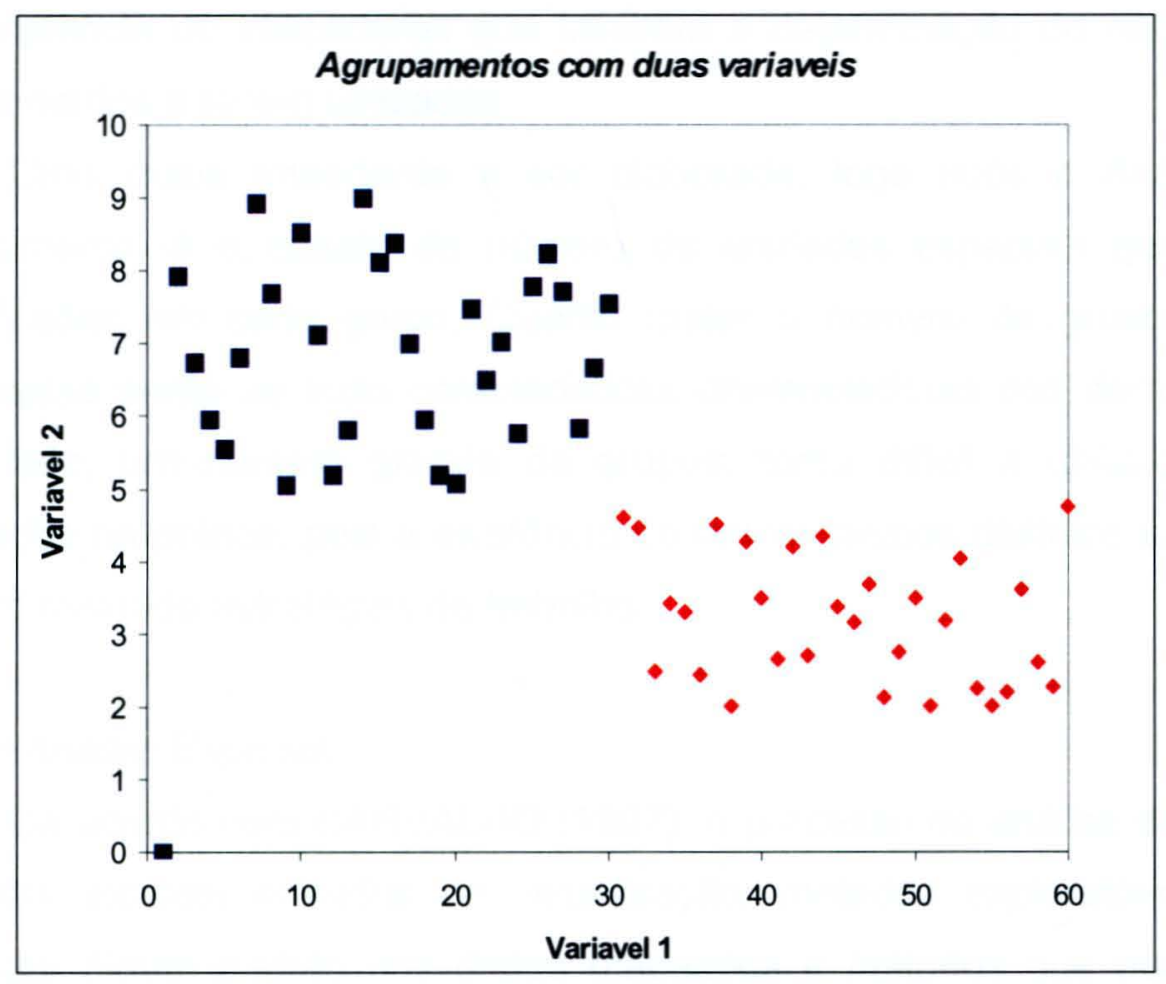

Fonte: Elaborado pela autora.

$\mathrm{Na}$ maioria das aplicações, as bases de dados não contêm somente duas variáveis. De fato, em muitos casos, é possível encontrar bases de dados com milhares de variáveis para cada registro. Nesses casos, uma inspeção visual similar à apresentada acima se torna inviável, de maneira que são necessárias técnicas sistemáticas mais eficazes para identificar os grupos homogêneos. Essas técnicas correspondem à área de estudo da análise de agrupamentos, ou, em inglês, "Cluster Analysis".

Apesar da idéia de agrupamentos parecer simples a primeira vista, existe atualmente uma infinidade de procedimentos nessa área. Muitos desses procedimentos são baseados em agrupamentos hierárquicos de registros, a partir de medidas de distâncias entre os registros no espaço formado pelas variáveis. No caso dos registros apresentados no gráfico acima, esses procedimentos hierárquicos poderiam se basear, por exemplo, no agrupamento consecutivo de registros (pontos no gráfico) que apresentem pequenas distâncias no plano formado pelas variáveis 1 e 2 . 
Uma vantagem desses procedimentos hierárquicos baseados em distâncias é a existência de indicadores que facilitam a determinação do número de agrupamentos a serem utilizados.

Uma etapa importante a ser elaborada, logo após a Análise de Agrupamento, é o estudo do número de unidades espaciais que foram classificadas em cada grupo. Quanto maior o número de grupos, mais acentuadas serão as suas características diferenciadoras dos demais. Por outro lado, um número grande de grupos, torna difícil a utilização dos resultados na prática, pois a existência de muitos grupos distintos exige um número maior de estratégias de trabalho.

\subsubsection{Análise Espacial}

De acordo com CARVALHO (1997), o processo de análise de dados espaciais incluem métodos de visualização, métodos exploratórios para investigar algum padrão nos dados mapeados e métodos que auxiliem a escolha de um modelo estatístico e a estimação dos parâmetros desse modelo.

As ferramentas da Análise Espacial podem ser divididas em seleção, manipulação, análise exploratória e confirmação (modelagem). (MAGUIRE 1991)

A seleção compreende os processos de consulta a um banco de dados geográfico; a manipulação envolve funções de criação de dados espaciais; a análise exploratória permite descobrir padrões de associação espacial (aglomerados espaciais), e as técnicas de análise confirmatória envolvem o conjunto de modelos de estimação e procedimentos de validação.

Com efeito, as técnicas de análise num Sistema de Informação Geográfica podem ter diferentes níveis de complexidade, conforme o exemplo da tabela abaixo:

Os dados que serão utilizados e processados apresentam diferentes unidades e escalas de análise, o que poderá levar a obtenção de diferentes significados. Deste modo, os padrões espaciais a serem observados para 
cada área, devem demonstrar consistência e particularmente, captar a significativa heterogeneidade local.

- Mapa Temático

Mapas temáticos são dados do tipo geo-campo e caracterizam-se por conter regiões definidas por um ou mais polígonos, como mapas de uso do solo e de aptidão agrícola de uma região. Este tipo de dado é armazenado na forma de arcos (limites entre regiões), incluindo os nós (pontos de interseções entre arcos) para montar uma representação topológica. (BURROUGH, 1998).

Neste tipo de análise espacial, os dados são agregados em unidades de análise, usualmente delimitadas por polígonos fechados (setor censitário, município, Distrito Policial, etc.), que no processo de geração do tema são agrupados em classes de acordo com a taxa eleita para sua segmentação.

\section{- Mapa de "Padrão Pontual"}

Outra taxonomia utilizada para caracterizar os problemas de análise espacial denominasse eventos ou padrões pontuais, que expressam fenômenos através de ocorrências identificadas como pontos localizados no espaço, denominados processos pontuais. São exemplos: localização de crimes, ocorrências de doenças, e localização de espécies vegetais.

Neste método, o objetivo está no estudo da distribuição espacial de pontos, que possibilitam o teste de hipóteses sobre o padrão observado: se é aleatório, ou ao contrário se apresenta em aglomerados ou regularmente distribuído. Onde o objeto de interesse é a própria localização espacial dos eventos em estudo. (CÂMARA et.al 2000).

Numa visão estatística, processos pontuais são definidos como um conjunto de pontos irregularmente distribuidos em um terreno, cuja localização foi gerada por um mecanismo estocástico. Para sua caracterização, este processo estocástico pode ser descrito em termos dos efeitos de primeira ordem (representa a intensidade do processo - número 
de eventos por unidade de área) e efeitos de segunda ordem (representa a dependência espacial no processo - correlação espacial).

\subsubsection{Processamento dos Dados}

De um modo geral, o processamento das informações se deu pela padronização das informações (projeções e formatos); tratamento estatístico dos bancos de dados, e agregação dos mesmos em superfície.

Os dados de origem gráfica sofreram um processo de padronização de formato (Maplnfo - TAB) e projeção (UTM - Córrego Alegre), anterior à aplicação das técnicas descritas no item 6.2.3.

\subsubsection{Correção da Base de Distritos Policiais}

$\mathrm{Na}$ base de Distritos Policiais foram encontradas algumas inconsistências, nos limites dos DP's com relação às suas descrições territoriais, obtidas pela Resolução SSP- 245. Estas inconsistências inviabilizariam a aplicação dos métodos de análise espacial selecionados. Desta forma, a base passou por um processo de correção, em que, um a um, os DP's foram sendo corrigidos e adequados à malha de eixo de logradouro coletada e a resolução que os definia. Esta correções foram elaboradas em escala de detalhe (1:2.000) para proporcionar maior qualidade a base. Um exemplo deste processo pode ser observado pelo Anexo A3.

\subsubsection{Definição de Áreas Homogêneas em Termos de Perfil de Crime}

Para o agrupamento dos Distritos Policiais, utilizou-se a técnica de Análise de Agrupamentos ("Cluster"). Nessa técnica, todos os Distritos foram inicialmente classificados como grupos de um único distrito, e a cada iteração, dois grupos foram "fundidos" em um único grupo, ou seja, na $2^{a}$ iteração, passou a existir 92 grupos, e assim por diante, até que na nonagésima terceira iteração obteve-se um único grupo formado por todos 
os 93 distritos. Assim, os distritos são agrupados conforme a "distância" entre os grupos de distritos.

A partir da base de dados do INFOCRIM, fornecida pela Secretaria de Segurança Pública de São Paulo, foi possível obterem-se diretamente as freqüências de crimes que ocorrem em cada área referentes aos distritos policiais (DP) na cidade de São Paulo. Dada às diferenças das características entre os vários DP's, esperou-se que a distribuição das ocorrências criminais não fosse homogênea em toda a cidade. No entanto, houve uma expectativa de que algumas dessas 93 áreas apresentassem certas similaridades, de forma que os perfis de crimes, nessas regiões, também fossem similares.

Num primeiro momento, fez-se necessária à descrição da análise estatística empregada para encontrar, a partir das informações extraídas do INFOCRIM, áreas similares em termos de perfil das ocorrências criminais.

Para cada DP, foram calculadas as freqüências de ocorrências para diversas agregações de categorias de crime, durante o periodo de janeiro de 2001 até agosto de 2003, totalizando 32 meses. Baseando-se nessas freqüências, pode-se analisar medidas de proximidade entre as características criminais para formar agrupamentos de unidades (distritos policiais) similares. A partir da definição destes agrupamentos geográficos, foi possivel, posteriormente, estudar as diferenças entre tais grupos, em termos de características sócio-econômicas e/ou de infra-estrutura.

Os agrupamentos de áreas homogêneas foram feitos com base em técnicas de análise estatística multivariada e seus resultados visualizados por meio dos Sistemas de Informação Geográfica.

A análise de agrupamentos descrita na etapa anterior pôde ser utilizada no encontro dos grupos homogêneos de distritos policiais na cidade de São Paulo, a partir das naturezas de ocorrências criminais. Para isso, foram definidos, inicialmente, os grupos de naturezas criminais (descritos no item de Investigação dos Dados). Em seguida, para cada um desses grupos

\footnotetext{
${ }^{33}$ Não entraremos em detalhes quanto ao cálculo das distâncias entre os grupos de distritos. Apenas é importante frisar, que a cada iteração os distritos mais próximos são agrupados.
} 
criminais, calculou-se o número de ocorrências em cada um dos tipos de crime selecionados para cada DP.

Uma das dificuldades encontradas na análise de agrupamentos para os diversos tipos de crimes foi a presença de uma população flutuante ${ }^{34}$ considerável em vários dos DP's.

Para a dificuldade encontrada, em se estimar as populações flutuantes em diversas áreas, a alternativa mais bem sucedida foi a de se trabalhar com os pesos de cada uma das 21 categorias de crime, descritas acima, para cada DP. A Tabela 3, a seguir, apresenta os pesos dos 21 tipos de crime descritos acima, para os exemplos de Parelheiros e da Vila Mariana. Observe que na região do DP de Parelheiros, mais de $12 \%$ das ocorrências entre os crimes considerados correspondem a furto de estabelecimentos. Na região do DP da Vila Mariana, esse número cai para em torno de $7 \%$. Por outro lado, na região da Vila Mariana, furto de veículos corresponde a quase $34 \%$ das ocorrências, enquanto no DP de Parelheiros, esse tipo de ocorrência corresponde a apenas $6 \%$ das ocorrências entre os crimes considerados nesta análise.

\footnotetext{
${ }^{34}$ As bases de dados existentes que descrevem a população flutuante, como a pesquisa de Origem e Destino do Metró e a RAIS, não foram utilizadas nesse estudo.
} 
Tabela 3 - Pesos dos diversos crimes para dois DP's na cidade de São Paulo.

\begin{tabular}{lll}
\hline Tipo de Crime & DP de Parelheiros & DP de Vila Mariana \\
\hline Estupro & $0,81 \%$ & $0,19 \%$ \\
Furto transeunte & $2,75 \%$ & $5,78 \%$ \\
Roubo transeunte & $6,89 \%$ & $15,74 \%$ \\
Furto cargas & $0,39 \%$ & $0,07 \%$ \\
Furto estabelecimentos & $12,81 \%$ & $7,39 \%$ \\
Furto outros & $1,70 \%$ & $2,24 \%$ \\
Furto pessoas & $7,36 \%$ & $5,54 \%$ \\
Furto residéncias & $6,95 \%$ & $3,69 \%$ \\
Furto transporte coletivo & $0,75 \%$ & $1,01 \%$ \\
Furto veículos & $6,05 \%$ & $33,52 \%$ \\
Homicídio doloso & $8,76 \%$ & $0,14 \%$ \\
Roubo de cargas & $1,61 \%$ & $0,10 \%$ \\
Roubo de estabelecimentos & $2,58 \%$ & $4,50 \%$ \\
Roubo outros & $3,61 \%$ & $2,49 \%$ \\
Roubo de pessoas & $5,06 \%$ & $1,16 \%$ \\
Roubo de residéncias & $1,97 \%$ & $0,37 \%$ \\
Roubo de transporte coletivo & $11,67 \%$ & $0,41 \%$ \\
Roubo de veículos & $17,43 \%$ & $15,40 \%$ \\
Seqüestro & $0,22 \%$ & $0,06 \%$ \\
Tráfico de entorpecentes & $0,52 \%$ & $0,14 \%$ \\
Roubo seguido de lesão grave ou morte & $0,09 \%$ & $0,06 \%$ \\
Total & $100,00 \%$ & $100,00 \%$ \\
\hline
\end{tabular}

Fonte: Elaborado pela autora.

Dadas às observações acima, a análise de agrupamentos realizada nessa etapa baseou-se em transformações das proporções de crimes em cada DP.

\subsubsection{Elaboração dos Mapas Temáticos}

\section{- Categorias Sócio-econômicas}

Para a obtenção do produto da análise espacial (mapeamento temático) sobre o nível sócio-econômico do município de São Paulo, foram utilizados os resultados obtidos pela aplicação da técnica de análise 
estatistica de Agrupamento, para criação de áreas homogêneas, realizadas pelo Instituto UNIEMP (Projeto para a organização de um Centro de Análise Criminal na Secretaria de Segurança Pública de São Paulo) para a Secretaria de Segurança Pública do Estado de São Paulo, no ano de 2003, disponibilizadas em DBF.

Após a obtenção do arquivo, no formato DBF, facilmente pôde-se lê-lo no software definido para a realização dos procedimentos de mapeamento temático e associá-lo ao arquivo contendo a cartografia georreferenciada dos setores censitários do município. Para a execução deste procedimento, foi utilizada a ferramenta de "seleção por SQL" do software Maplnfo 7.5. Assim a base de dados de setores censitários, no formato DBF, foi equiparada a base de dados em formato TAB (Maplnfo), através da coluna contendo o número do setor censitário, presente em ambos os arquivos. $E$ a nova base de dados gerada, passou a conter a cartografia georreferenciada dos setores, acrescida da tabela oriunda da Análise de Agrupamento Sócioeconômico.

A partir da nova base de dados, foi possível então, se gerar o mapa temático sobre os segmentos criados.

- Distritos Policiais

Para a obtenção do produto da análise espacial (mapeamento temático) sobre o nível dos Distritos Policiais do município de São Paulo, foram utilizados os resultados obtidos pela aplicação de técnicas de análise estatística de Agrupamento, para criação de áreas homogêneas, descrita na etapa anterior, e disponibilizadas em DBF.

Após a obtenção do arquivo, no formato DBF, facilmente pôde-se lê-lo no software definido para a realização dos procedimentos de mapeamento temático e associá-lo ao arquivo contendo a cartografia georreferenciada dos DP's do município. Para a execução deste procedimento, foi utilizada a ferramenta de "seleção por SQL" do software Maplnfo 7.5. Assim a base de dados de DP's, no formato DBF, foi equiparada a base de dados em formato TAB (Maplnfo), através da coluna contendo o número do DP, presente em 
ambos os arquivos. E a nova base de dados gerada, passou a conter a cartografia georreferenciada dos DP's, acrescida da tabela oriunda da Análise de Agrupamento em termos de perfil de crime.

A partir da nova base de dados, foi possível então, gerar o mapa temático sobre os segmentos criados.

\subsubsection{Elaboração dos Mapas por "Padrão Pontual"}

Neste estudo, a criação de pontos foi realizada a partir da ferramenta de "Criação de Pontos" disponivel no software Maplnfo 7.5, utilizando-se as colunas contendo as coordenadas planas disponiveis na base de dados fornecidos pela SSP-SP no formato DBF.

Após a criação dos pontos das ocorrências criminais, aplicou-se a ferramenta "Dispersão de Pontos" do software, para que os pontos sobrepostos fossem distribuídos, possibilitando, assim, uma melhor visualização do evento no espaço.

A partir da criação dos pontos para cada natureza selecionada (Homicídio, Tentativa de Homicídio, Latrocínio, Roubo à Residência, Transeunte, Veículo e Interior de Veículo) no período de abril de 2003 a março de 2004 para o município de São Paulo; foram elaborados os mapas por "Padrão Pontual".

Para a montagem de mapas por "Padrão Pontual", as bases de dados georreferenciadas devem ser apresentadas dentro de um formato visual que facilite a leitura e a análise criminal.

Com base em diversos testes realizados, com fim ao alcance da melhor distribuição visual para as informações coletadas, chegou-se a um padrão de simbologia, cores, nomenclaturas ${ }^{35}$ e "layouts" que facilita a análise do especialista criminal.

Os padrões definidos encontram-se descritos no Anexo A4, segundo o software utilizado (Maplnfo 7.5).

\footnotetext{
${ }^{35}$ A nomenclatura utilizada nos mapas encontra-se igual aos termos empregados pela Resolução 160.
} 
Para a elaboração deste item, foram selecionados Distritos Policiais de diferentes áreas do município, para que a distribuição do crime fosse mais bem representada e os objetivos propostos alcançados.

A partir da aplicação da técnica de dispersão sobre os eventos criminais criados por "Padrão Pontual", pôde-se observar as aglomerações geográficas dos crimes selecionados.

Estas aglomerações identificadas com padrões de distribuição heterogêneo entre os distritos selecionados, podem ser denominadas de hot spot.

Existem diversas formas de se determinar um hot spot, algumas delas meramente visuais e outras por meio de análise estatística de dados, unindo-se várias fontes de informações criminais.

Neste estudo, se fez uso apenas dos dados gerados pelo INFOCRIM. No entanto, a identificação dos hot spots poderia ganhar maior acuidade com a incorporação das informações provenientes do "Disque-Denúncia" e do "Atendimento 190" uma vez que os B.O.s representam uma pequena parcela dos incidentes criminais ocorridos em uma determinada área ${ }^{36}$.

\footnotetext{
${ }^{36}$ Pesquisas de vitimização indicam que em média, apenas $20 \%$ dos casos chegam ao conhecimento da Polícia. (IFB 2003)
} 


\title{
7 RESULTADOS E DISCUSSÃO
}

\author{
A articulação, fundamentada na relação dialética \\ entre o particular, o singular e o universal, dá ao \\ fenômeno sua dimensão plena. (CARLOS 1994, p.32)
}

\subsection{Distribuição Espacial de Variáveis Sócio-Econômicas no Municipio de São Paulo}

A partir da elaboração do mapa temático, por categorias sócioeconômicas, obteve-se áreas homogêneas com características semelhantes. Estas características podem ocorrer em relação a qualquer informação sobre a superficie disponivel. Nesse ponto é importante observar que diferentes informações podem levar a diferentes agrupamentos, principalmente quando as informações têm pouco ou nenhuma relação espacial entre si.

A Figura 7, apresenta a distribuição dos segmentos na cidade de São Paulo. Note que setores pertencentes a um mesmo segmento tendem e ficarem próximos no mapa, mostrando que a Análise de Agrupamentos produziu muito provavelmente segmentos coerentes. Sobre os agrupamentos formados no mapa, foi inserida a base de Delegacias de Policia (DP's), que apresentam um número, referente a cada Delegacia, para facilitar sua identificação (estes números, com suas respectivas nomenclaturas se encontram em Anexo A5). 


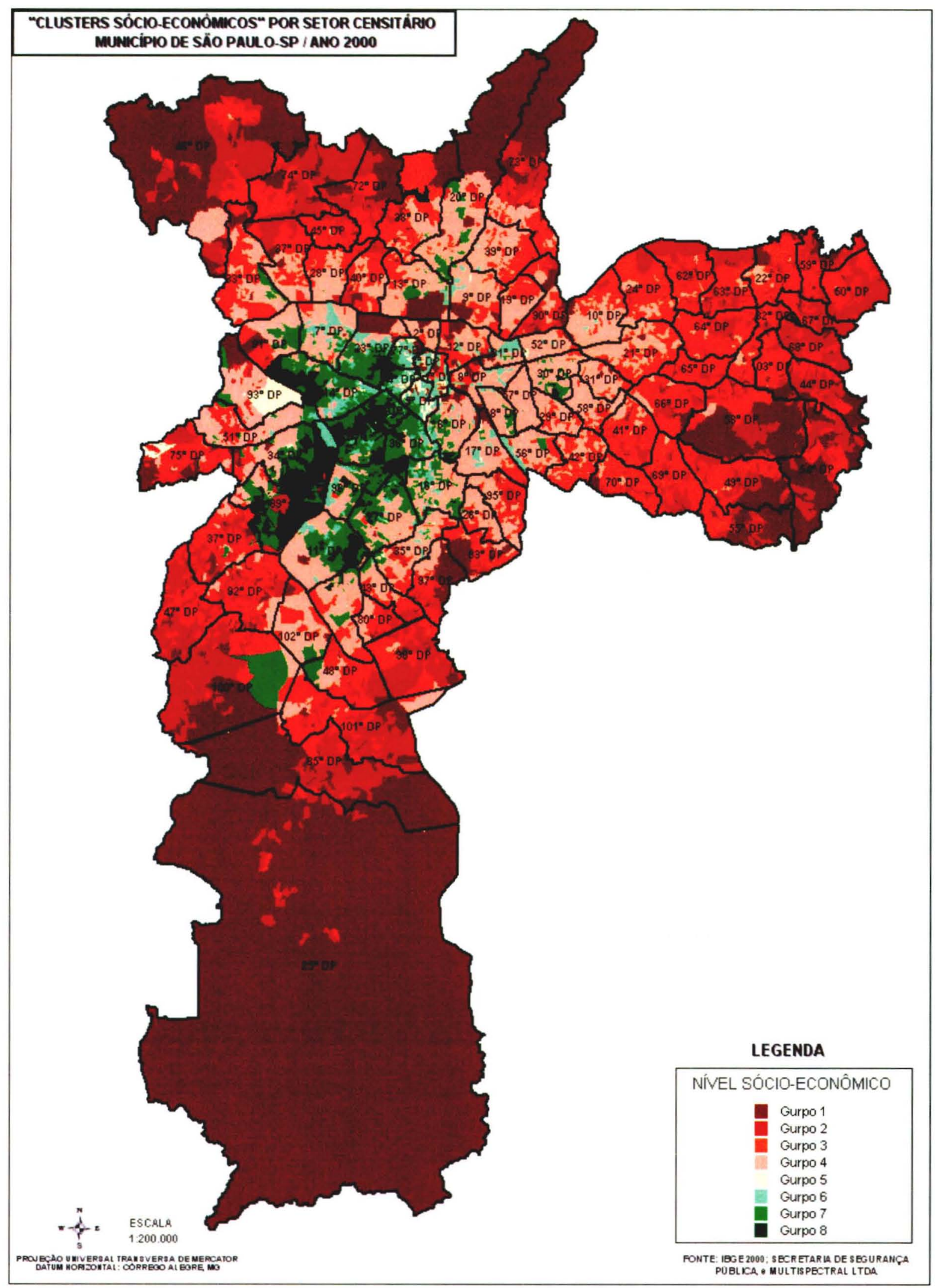

Figura 7 - "Clusters sócio-econômicos” por setor censitário. 


\subsection{Distribuição Espacial do Crime pela Unidade dos Distritos Policiais (DP)}

É natural esperar que alguns crimes sejam relacionados, seja por acontecerem em lugares com as mesmas características, por ocorrerem nos mesmos períodos do dia (ou da semana), ou por vitimarem pessoas de perfil semelhante. Por exemplo, em lugares onde a ocorrência de furto de documentos é alta, espera-se também alta ocorrência de roubo a transeuntes. Sendo assim, é de interesse encontrar agrupamentos que respeitem essas características inerentes aos crimes, seja para entender a causa desses crimes, seja para desenvolver políticas de intervenção que levem em consideração a relação desses crimes, ou para criar índices que consigam determinar se uma determinada região sofre com crimes que possuam alguma caracteristica em comum.

Após a utilização dos procedimentos estatísticos para obtenção do agrupamento de DP's, de acordo com perfil de naturezas de ocorrências, chegou-se a seis (6) grupos homogêneos, conforme especificado no Anexo A6

A descrição dos grupos encontrados está apresentada na Tabela 4, a seguir: 
Tabela 4 - Caracteristicas dos agrupamentos homogêneos de DP's em São Paulo.

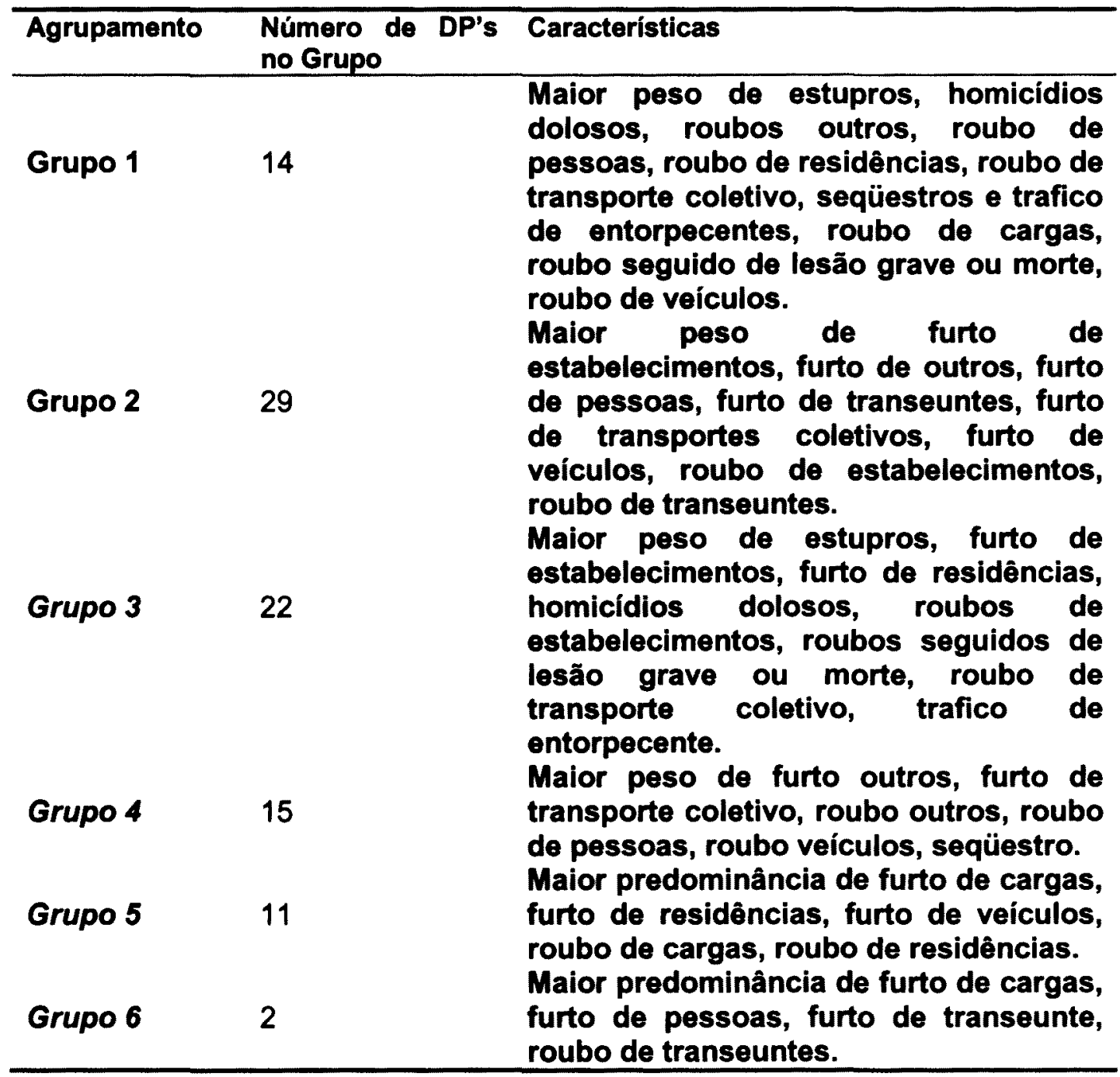

Fonte: Elaborado pela autora.

Finalmente, uma melhor visualização dos resultados pode ser obtida, a partir do mapeamento dos diversos distritos policiais e seus respectivos grupos homogêneos. Nesse caso, se utilizou os recursos dos Sistemas de Informação Geográfica (SIG), através da técnica de mapa temático, descrito no capitulo anterior, para representar os grupos de distritos policiais da capital, conforme demonstra a Figura 8. 


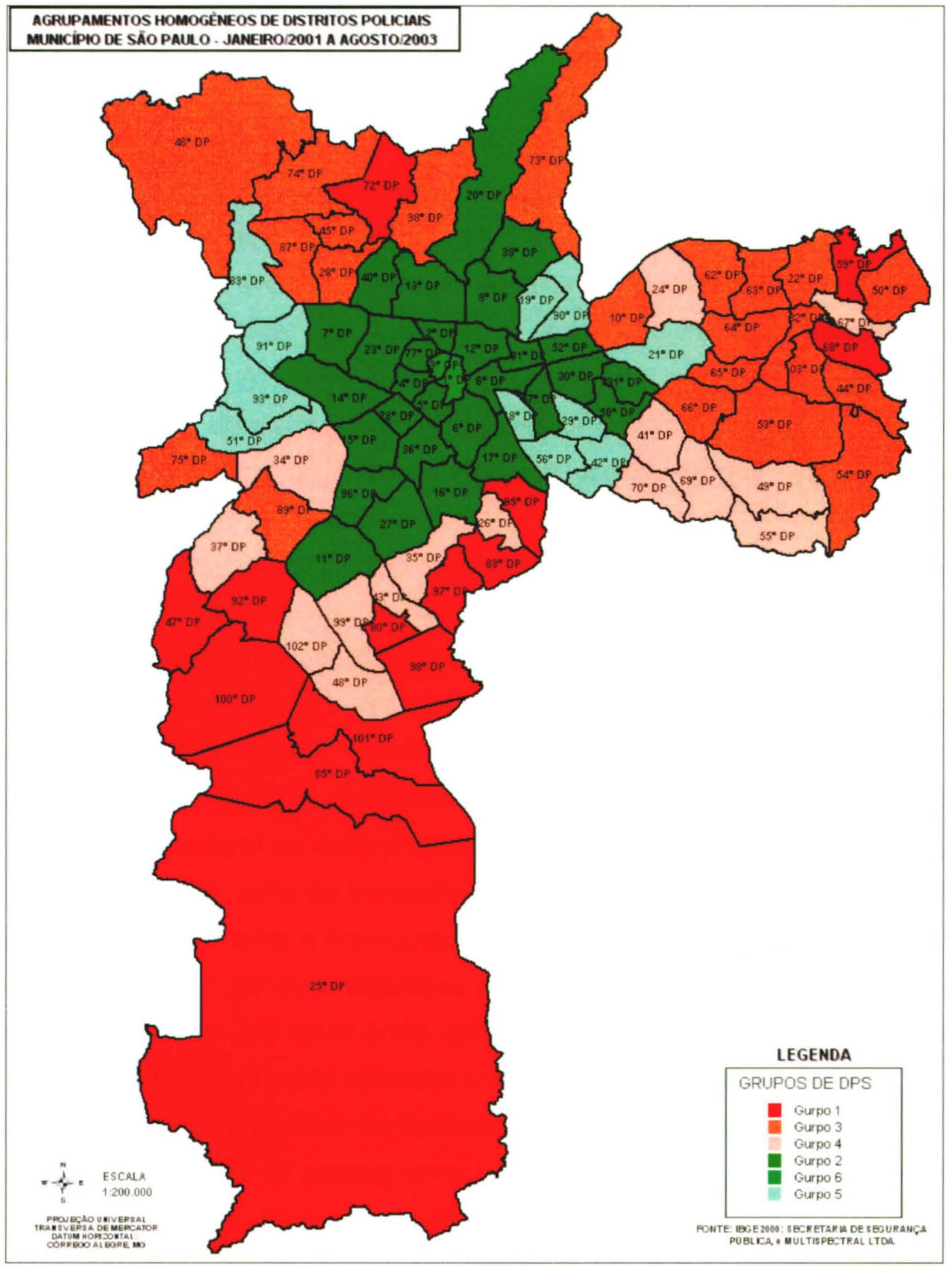

Figura 8: Agrupamentos homogêneos de distritos policiais 
Para o entendimento e validação da Análise de Agrupamento ("Cluster") de DP's gerada foram utilizadas algumas fontes de informação, como a localização de favelas, as principais redes de transporte coletivo e malhas viárias da capital, além das características sócio-econômicas, obtidas pelo mapa de "Clusters sócio-econômicos" por setor censitário (Figura7); criado sobre variáveis do Censo demográfico do IBGE e descrito no item anterior.

Com efeito, para se averiguar a relação de cada agrupamento com as variáveis de interesse, pode fazer uso, também, da técnica de Análise Discriminante, apresenta no Anexo $\mathrm{A} 7$.

O grupo 1 de distritos policiais apresenta a maior incidência de crimes mais violentos. A partir do mapa da Figura 8, observa-se que esses distritos estão espalhados na periferia da cidade.

O mapa de "Clusters sócio-econômicos" por setor censitário (Figura 7) integrado a cartografia georreferenciada dos DP's, indica, que esse grupo de distritos policiais corresponde às áreas de menor renda "per capita", maior número de moradores por residência, menor média de escolaridade do responsável pelo domicilio, e maior proporção de jovens. Por outro lado, o grupo 2 apresenta uma incidência grande de crimes economicamente motivados, como furto de estabelecimentos, furto de outros, furto de pessoas, furto a transeuntes, furto de transportes coletivos, furto de veiculos, roubo de estabelecimentos, roubo a transeuntes. Ao se observar o mapa de "Clusters sócio-econômicos" por setor censitário, ("Clusters sócio-econômicos" por setor censitário), nota-se que estas áreas apresentam a maior renda "per capita", a maior média de escolaridade e a maior proporção de pessoas mais velhas.

Em termos de padrões de violência nos atos criminais, o agrupamento 3 se aproxima bastante do agrupamento 1, embora o 3 tenha características um pouco mais brandas. Com relação as variáveis de renda, idade, escolaridade etc., o grupo 3 também possui características um pouco melhores quando comparado ao grupo 1. Observe, na Figura 9, que o grupo 3 também é mais próximo ao centro da cidade, indicando uma onda de ocupação mais antiga. 
O próximo agrupamento (grupo 4) apresenta, também, características sócio-econômicas melhores que os grupos 1 e 3, além de estar mais próximo ao grupo 2 (o grupo de melhores características sócio-econômicas). Observase, a partir do mapa da Figura $X$ (Agrupamentos homogêneos de distritos policiais com favelas), que as favelas da cidade estão localizadas predominantemente nos grupos 1,3 e 4 . 


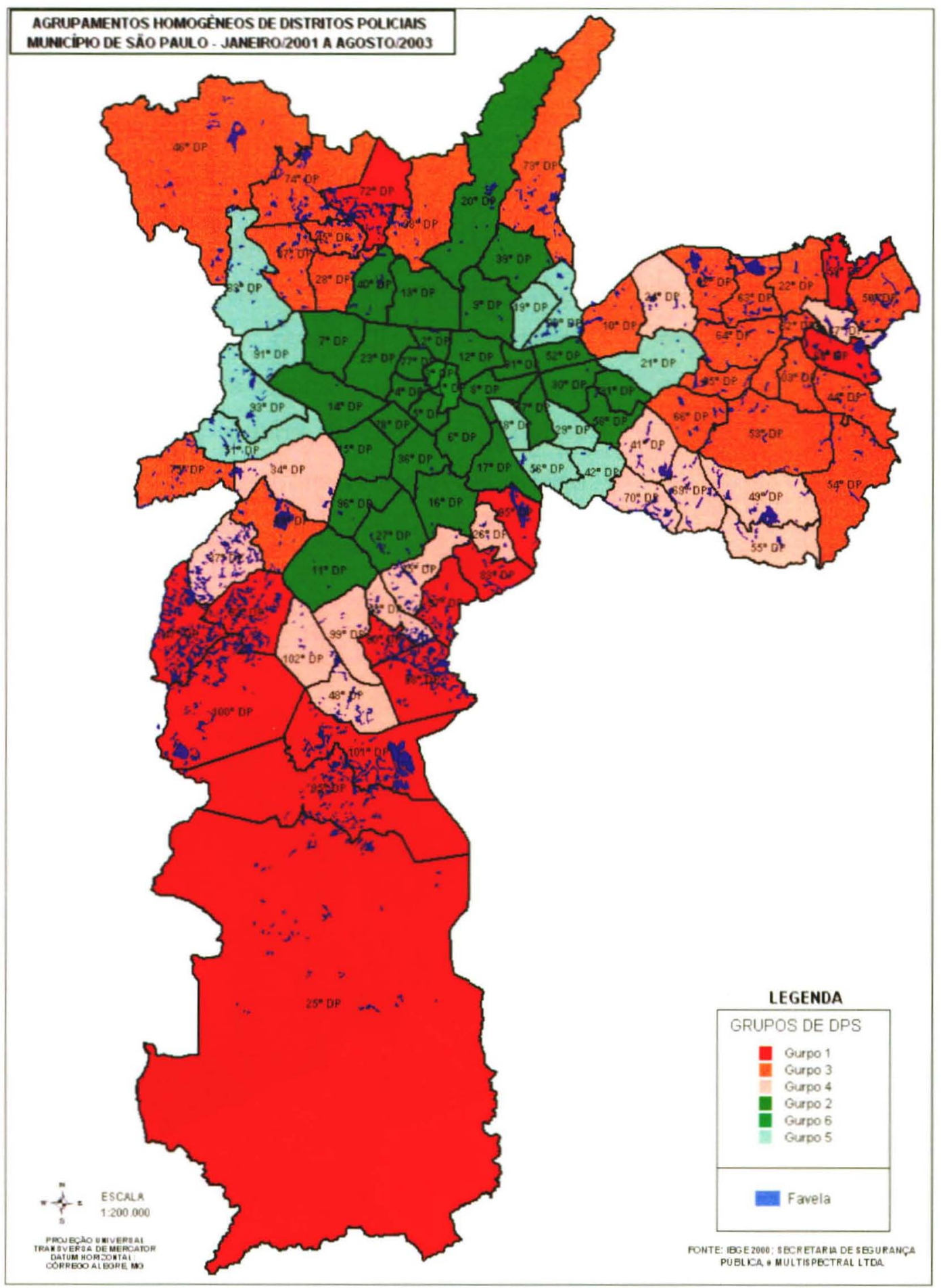

Figura 9 - Agrupamentos homogêneos de distritos policiais com favelas. 
A análise de agrupamentos também indicou um grupo contendo grande incidência de furto de cargas, furto de residências, furto de veículos, roubo de cargas e roubo de residências. Este grupo (denominado 5), em termos de variáveis sócio-econômicas, possui características razoáveis, além de também de estar próximo ao grupo 2 e ao centro da cidade, que indica uma onda de ocupação antiga. Um atributo interessante desse grupo é a existência de rodovias importantes (Via Dutra e Rodovia Castelo Branco) e outras vias movimentadas passando pelos DP's pertencentes a esse agrupamento, observadas no mapa da Figura 10. Isso pode explicar, por exemplo, a alta incidência de furtos e roubos de cargas, haja vista a possível existência de depósitos e companhias de transporte nessas regiões.

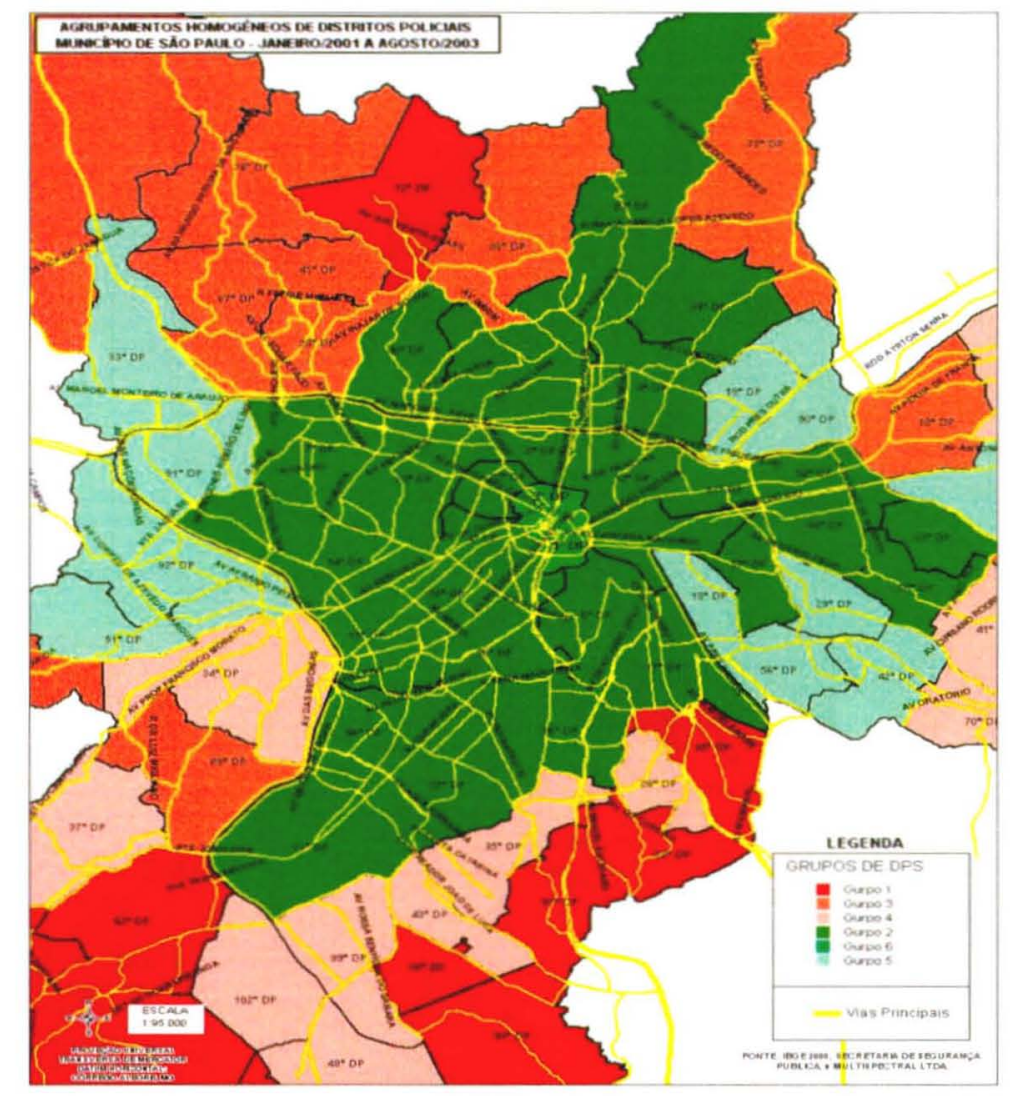

Figura 10 - Agrupamentos distritos policiais com vias principais 
Finalmente, no grupo 6, que apresenta apenas dois distritos policiais (Sé e Campo Elíseos), predominam furtos e roubos a transeuntes, furtos de cargas e furtos de pessoas ("bip", "pagers", celulares e documentos). Uma explicação para isso pode estar no alto número de pessoas que transitam nestas áreas diariamente. De fato, o mapa de Agrupamentos homogêneos de distritos policiais com rede transporte (Figura 11), demonstra a existência de entroncamentos de vias de trânsito e de transportes coletivos nestes distritos policiais.

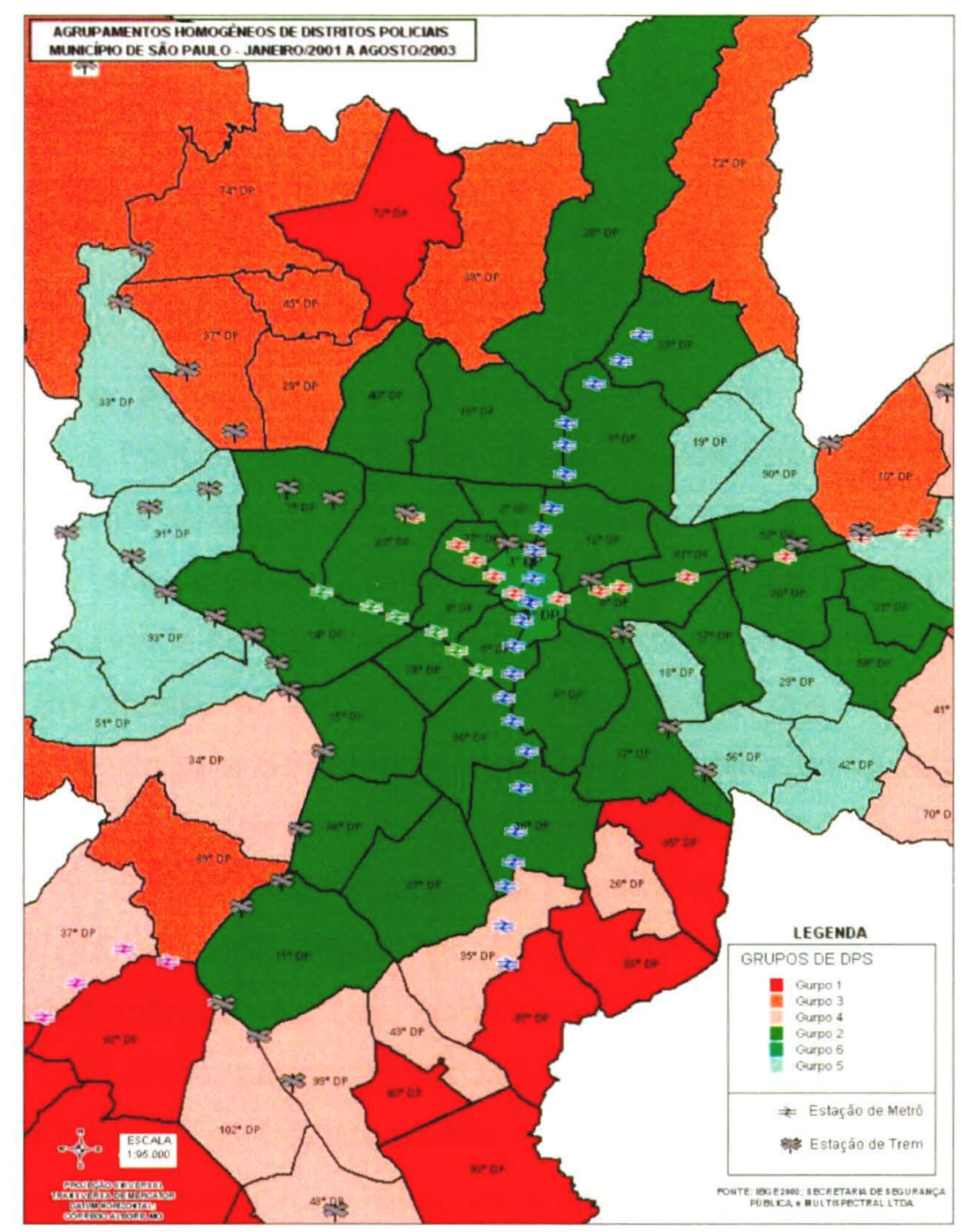

Figura 11 - Agrupamentos distritos policiais com rede transporte. 
Uma análise mais detalhada ainda pode ser realizada, mas requer maior quantidade de informações precisas sobre a cidade.

Os distritos policiais são unidades muito agregadas, e impossibilitam uma análise mais detalhada sobre a dinâmica da criminalidade. Por outro lado, uma análise baseada nos aproximadamente treze mil e quinhentos setores censitários, pertencentes ao Censo Demográfico do IBGE, tem a desvantagem de unidades muito desagregadas.

O grande problema com a desagregação apresentada pelos setores censitários é que muitas das análises estatísticas são baseadas na contagem do número de ocorrências em cada setor censitário. Devido à pequena metragem quadrada de cada uma dessas áreas, o número de ocorrências acaba sendo muito pequeno, ou até mesmo nulo, em muitos setores. Esse problema pode causar alguns vieses no resultado, levando a conclusões equivocadas.

Uma solução alternativa para o problema de alta agregação das Delegacias Policiais e de alta desagregação dos setores censitários pode ser obtida através do uso de sub-setores policiais.

Os sub-setores policiais são subdivisões das Delegacias Policiais, e dividem a cidade de São Paulo em aproximadamente mil unidades.

Entretanto, a cartografia georreferenciada dos sub-setores policiais, disponibilizada pela Secretaria de Segurança Pública do Estado de São Paulo, apresenta inconsistências na área compreendida por seus polígonos. Este problema fica visível quando a base cartográfica com os limites circunscricionais dos órgãos da Polícia Civil e Polícia Militar, os Distritos Policiais, é sobreposta a esta, como se pode observar no Anexo A8.

Com efeito, para que este arquivo de sub-setores seja disponibilizado à análise criminal, se faz necessária à correção gráfica de todos os elementos (sub-setores) deslocados geograficamente de seus respectivos conjuntos (Distrito Policial). 


\subsection{Distribuição espacial do crime "por ponto" na escala do Distrito Policial}

O aprofundamento da análise pode ser feito com uma mudança de escala, buscando trabalhar com a representação espacial dos Distritos Policiais e a técnica de pontos (cada episódio $=$ um ponto) inseridos no local de ocorrência do crime.

Segundo Martinelli (1991) este método é mais adequado para a representação de fenômenos com um padrão de distribuição disperso.

- mapa resultante permite-nos uma dupla percepção: a das densidades, obtida pela relação entre o preto dos pontos em contraste com o fundo branco do papel $e$ a das quantidades constatadas através da contagem dos pontos, os quais se adicionam visualmente, com grande facilidade (MARTINELLI, 1991, P. 93).

Nesta análise, foram utilizados os quatro Distritos Policiais, descritos anteriormente, por apresentarem padrões diferenciados de criminalidade, que propiciariam maior riqueza de dados para discussão: Morumbi, Capão Redondo, Sé e Santo Amaro.

Para esta parte do trabalho, foram utilizados Boletins de Ocorrência (BO's) referentes ao período de abril de 2003 a março de 2004. Os pontos representados nos mapas referem-se ao local de ocorrência do crime, registrado pelo INFOCRIM. Trabalhou-se com o periodo de um ano para evitar flutuações sazonais da criminalidade, que ocorrem na cidade. $A$ análise temporal da violência não era objetivo deste trabalho, apesar de representar um campo interessante de investigação (MENDONÇA, 2001).

Optou-se por analisar comparativamente as quatro regiões, em relação aos seguintes crimes: a) homicídios, tentativas de homicídio e latrocínio

b) estupro 
c) roubos: à residência, veículos, interior de veículos e transeuntes.

\subsubsection{Crimes Contra a Pessoa}

\subsubsection{Homicídios $^{37}$}

A partir da década de 1990, os homicídios passaram a ser a primeira causa de morte entre as causas externas no Brasil. Durante aquela década houve 401.090 óbitos por agressões externas (homicídios), no país todo, e estes números vêm aumentando ano a ano (MINISTÉRIO DA SAÚDE, 2004).

Essas agressões afetam, direta ou indiretamente, toda a população, porém alguns grupos populacionais mostraram-se mais vulneráveis, assim como algumas localidades indicaram maiores riscos que outras.

Em 2001 ocorreram 46.685 homicídios no país (taxa 27,8 por 100.000 ), sendo $71,5 \%$ provocados por armas de fogo. A faixa etária mais atingida foi a de 15 a 49 anos de idade, com 41.795 óbitos, representando $89 \%$ dos casos. $O$ sexo masculino apresentou taxas bem mais elevadas que o sexo feminino: 51,9 por 100.000 habitantes dentre os homens e 4,4 por 100.000 habitantes dentre as mulheres (MINISTÉRIO DA SAÚDE, 2004).

Verificou-se uma distribuição bastante desigual entre os estados, com as taxas mais elevadas em Pernambuco (58,6 por 100.000 habitantes); Rio de Janeiro (46 por 100.000); e São Paulo (41,8 por 100.000), em 2001. (MINISTÉRIO DA SAÚDE, 2004).

No Estado de São Paulo, houve uma estagnação no aumento da mortalidade por agressões, nos últimos 4 anos.

\footnotetext{
${ }^{37}$ Homicídio culposo por acidente de trânsito é dar causa a morte de alguém por imperícia, imprudência ou negligência no trânsito.

Homicídio culposo (excluindo por acidente de trânsito) é dar causa a morte de alguém sem intenção, ou seja, por imperícia, imprudência ou negligência.

Homicídio Doloso é Matar alguém intencionalmente.

(Adaptado da Resolução SSP - 160)
} 
Um outro dado interessante é que os óbitos por agressão, no Estado de São Paulo, ocorreram preferencialmente em finais de semana (domingo e sábado), conforme pode ser observado no quadro abaixo:

Quadro 8 - Distribuição dos óbitos por agressōes segundo o dia da semana. Estado de São Paulo - 2001

\begin{tabular}{|l|l|}
\hline Dia da Semana & $\%$ dos óbitos \\
\hline Segunda-feira & 12,95 \\
\hline Terça-feira & 11,49 \\
\hline Quarta-feira & 11,49 \\
\hline Quinta-feira & 11,71 \\
\hline Sexta-feira & 13,49 \\
\hline Sábado & 19,13 \\
\hline Domingo & 19,74 \\
\hline
\end{tabular}

Fonte: Sistema de Estatisticas Vitais - Fundação SEADE in Borlina Maia, P. (2003) n.p.

Tal fato indica que possivelmente muitos desses óbitos podem ocorrer em situações de lazer, com consumo de bebida alcoólica ou drogas.

Os solteiros constituem grupo de maior risco, uma vez que $69 \%$ dos óbitos por agressões ocorreram neste grupo e só $16 \%$ entre os casados.

Estes dados nacionais e estaduais servem de pano de fundo para os dados de homicídios demonstrados no município de São Paulo. Verifica-se que nesta escala de maior detalhe, representada pela área urbana municipal, a mortalidade por agressão também não é homogênea.

O risco de um cidadão paulistano morrer por esta causa é diferencial no espaço por uma série de fatores sociais, econômicos e demográficos: sexo, idade, estado civil, situação de empregabilidade, local de residência, presença / 
ausência de policiamento, para citar alguns, como pode ser verificado no mapeamento dos homicídios na capital do Estado. 


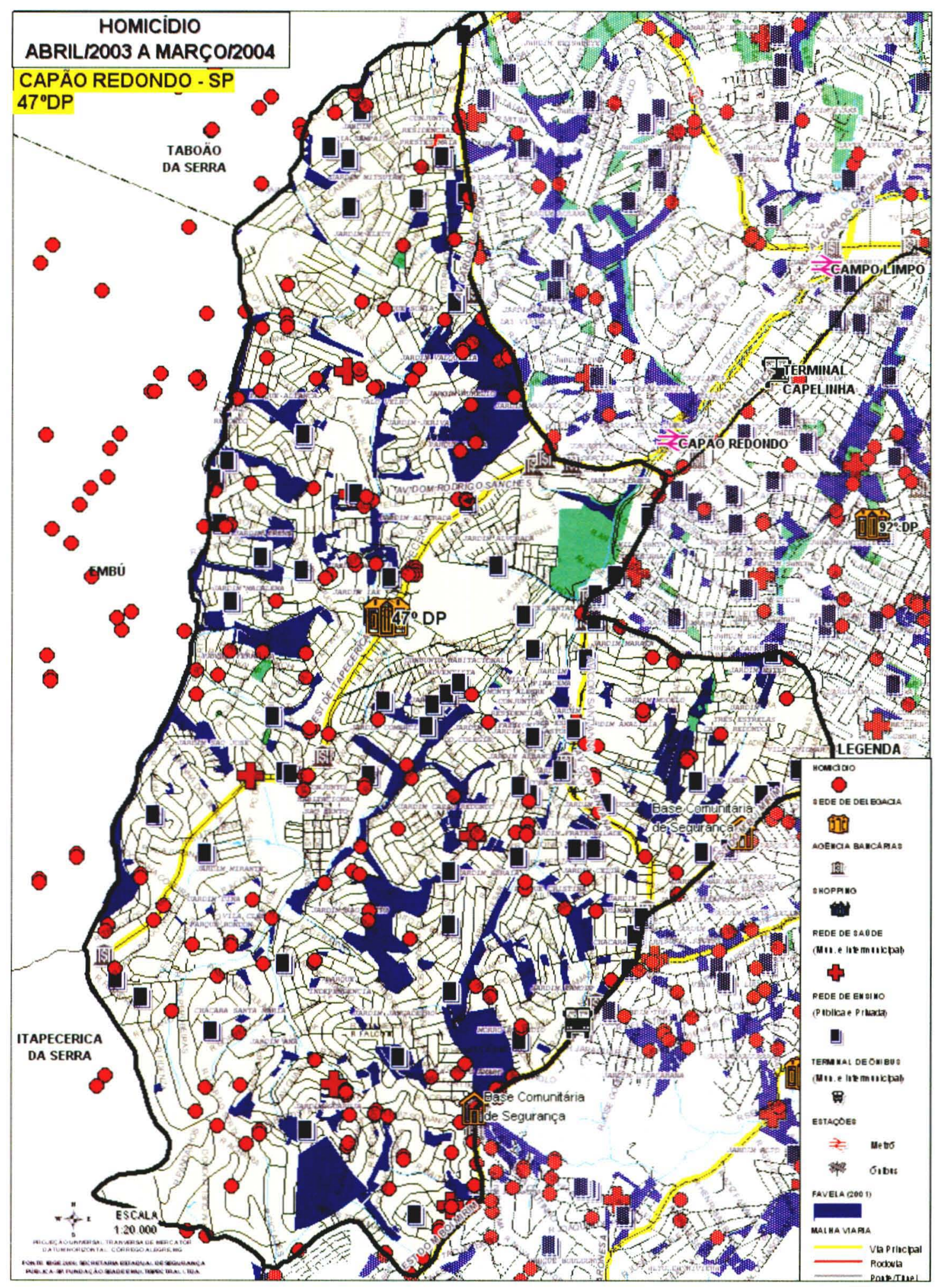

Figura 12: Homicídio - Capão Redondo. 


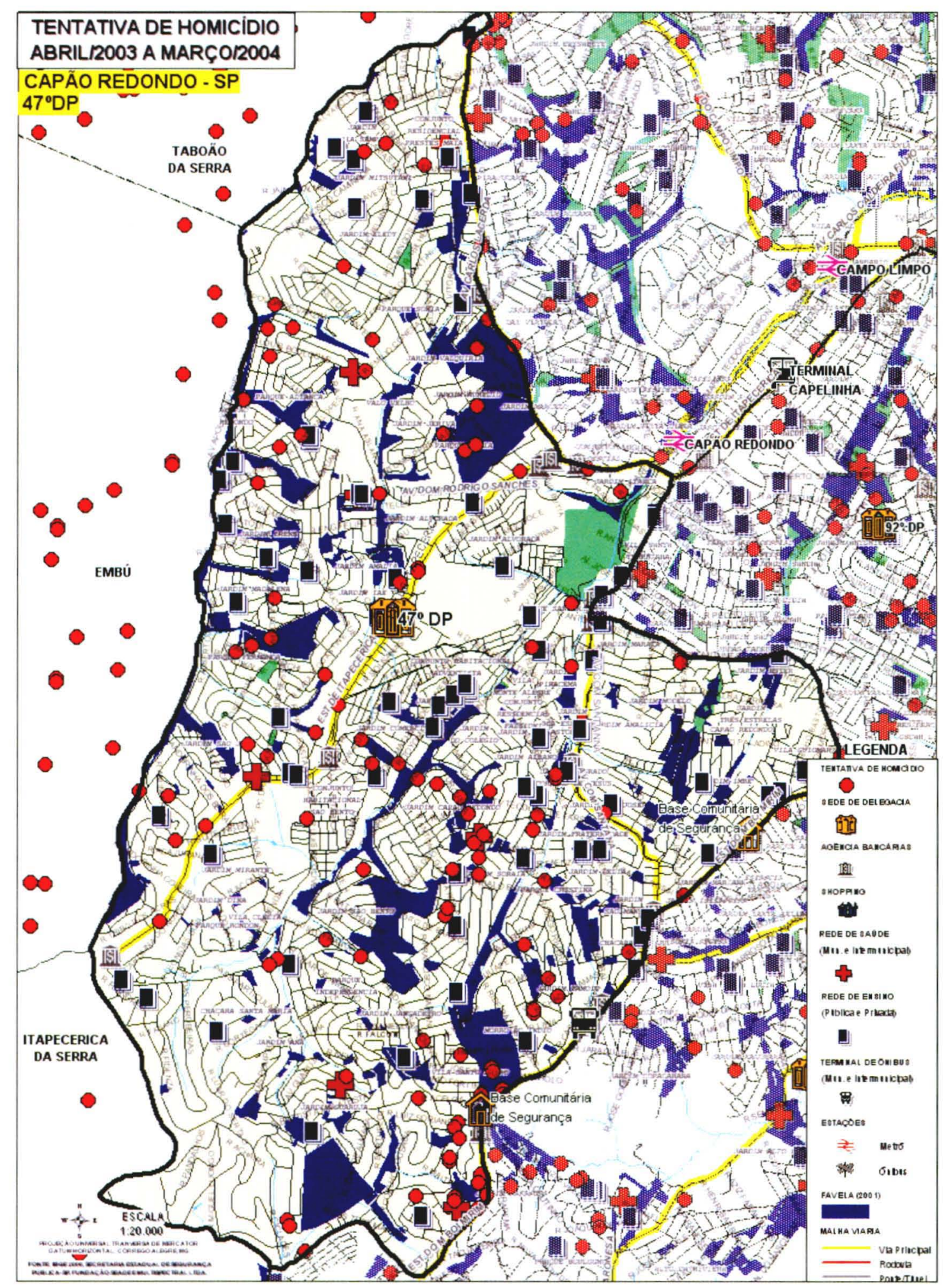

Figura 13 - Tentativa de Homicídio - Capão Redondo 


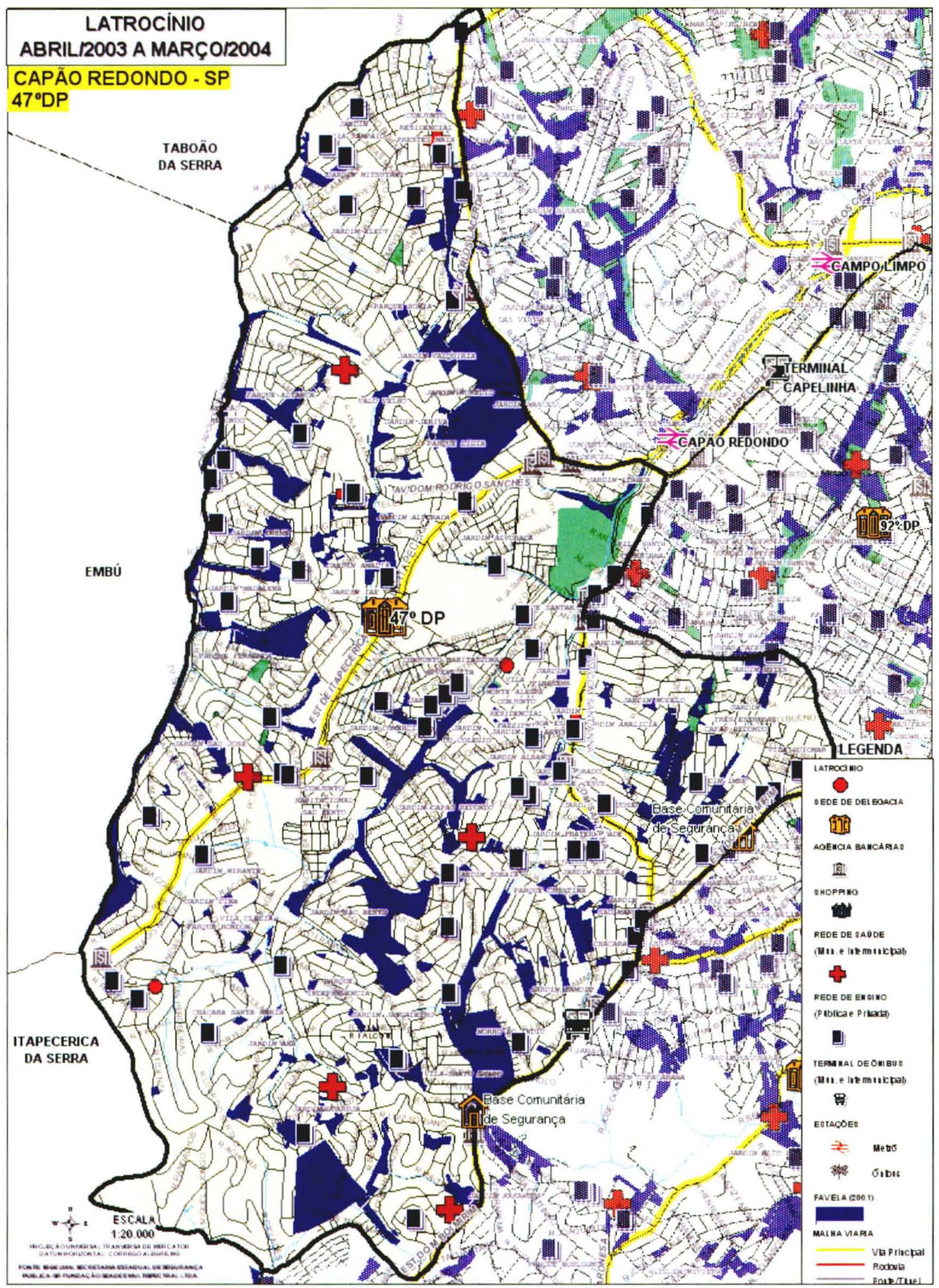

Figura 14 - Tentativa e Homicídio - Capão Redondo 


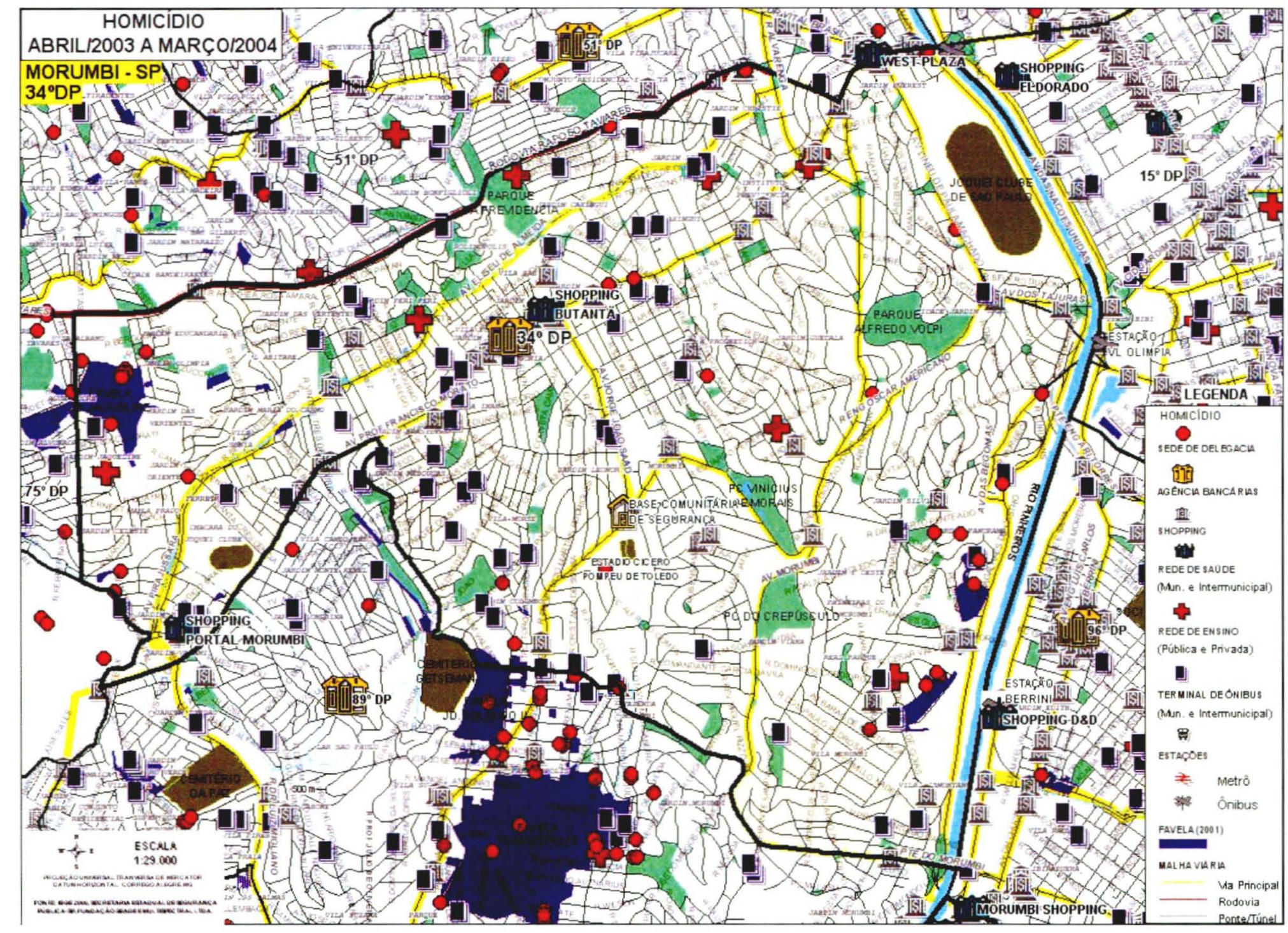

Figura 15 - Homicído - Morumbi 


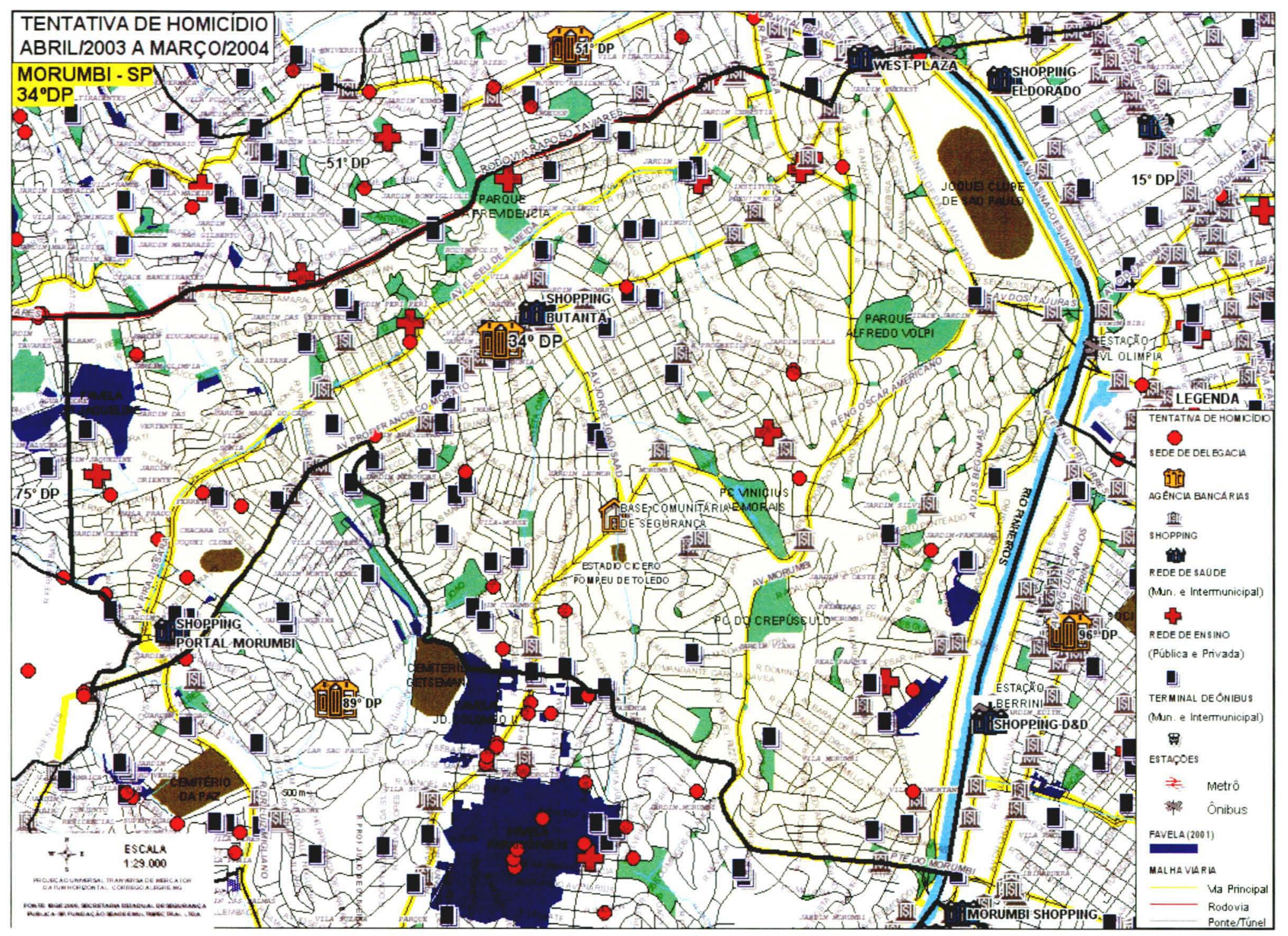

Figura 16 - Tentativa de Homicído - Morumbi 


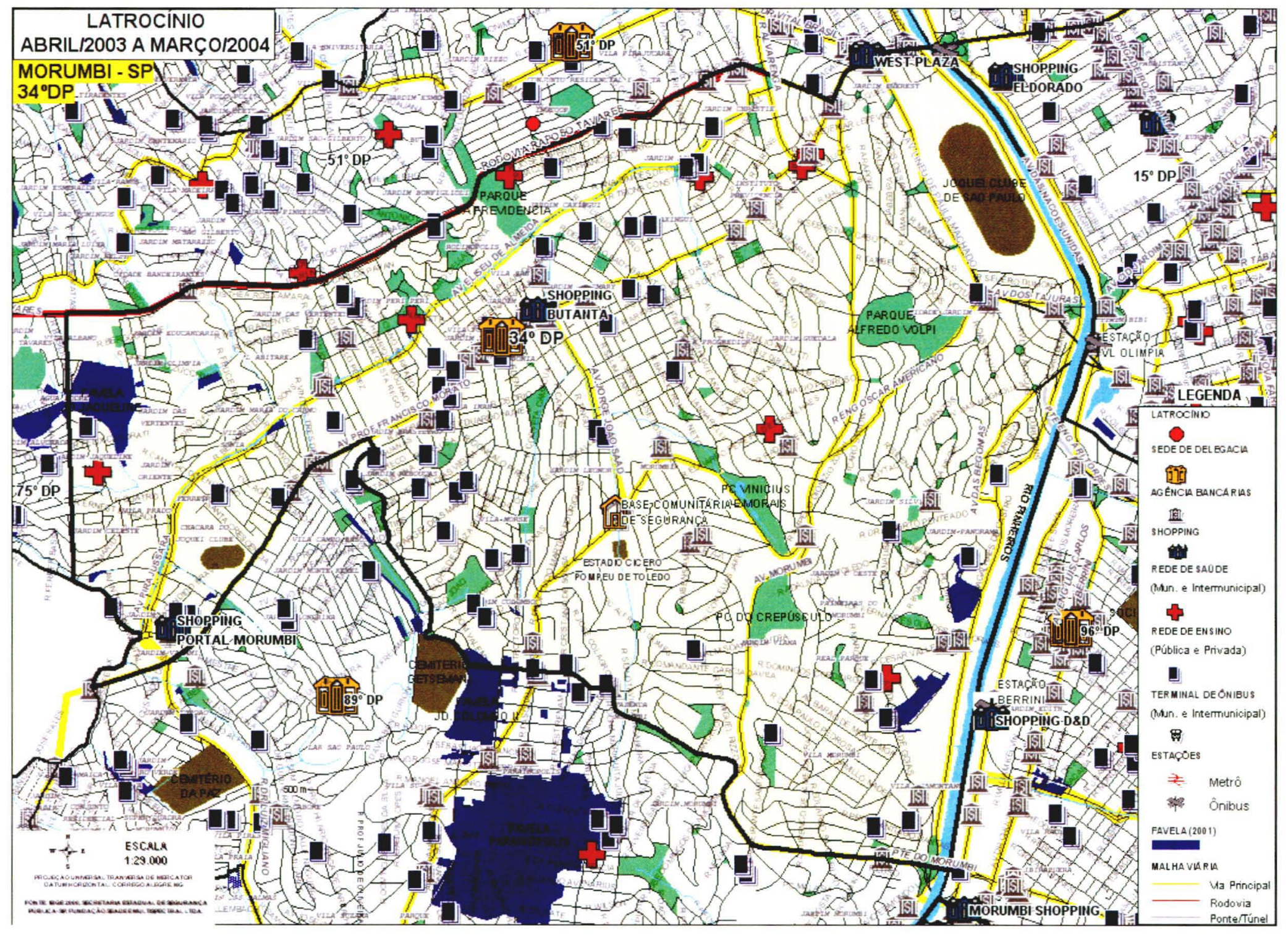

Figura 17 - Latrocínio - Morumbi 


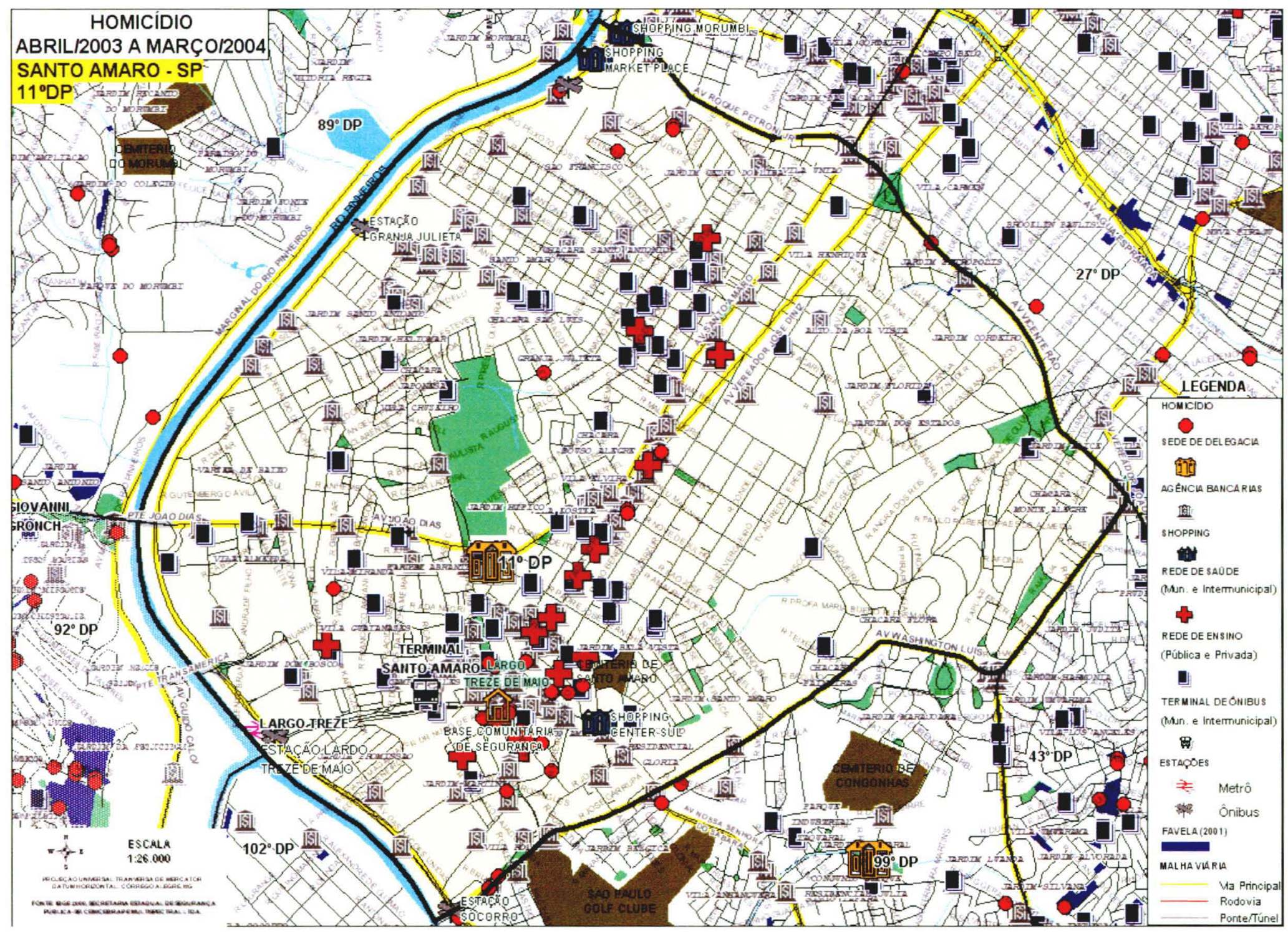

Figura 18 - Homicídio - Santo Amaro 


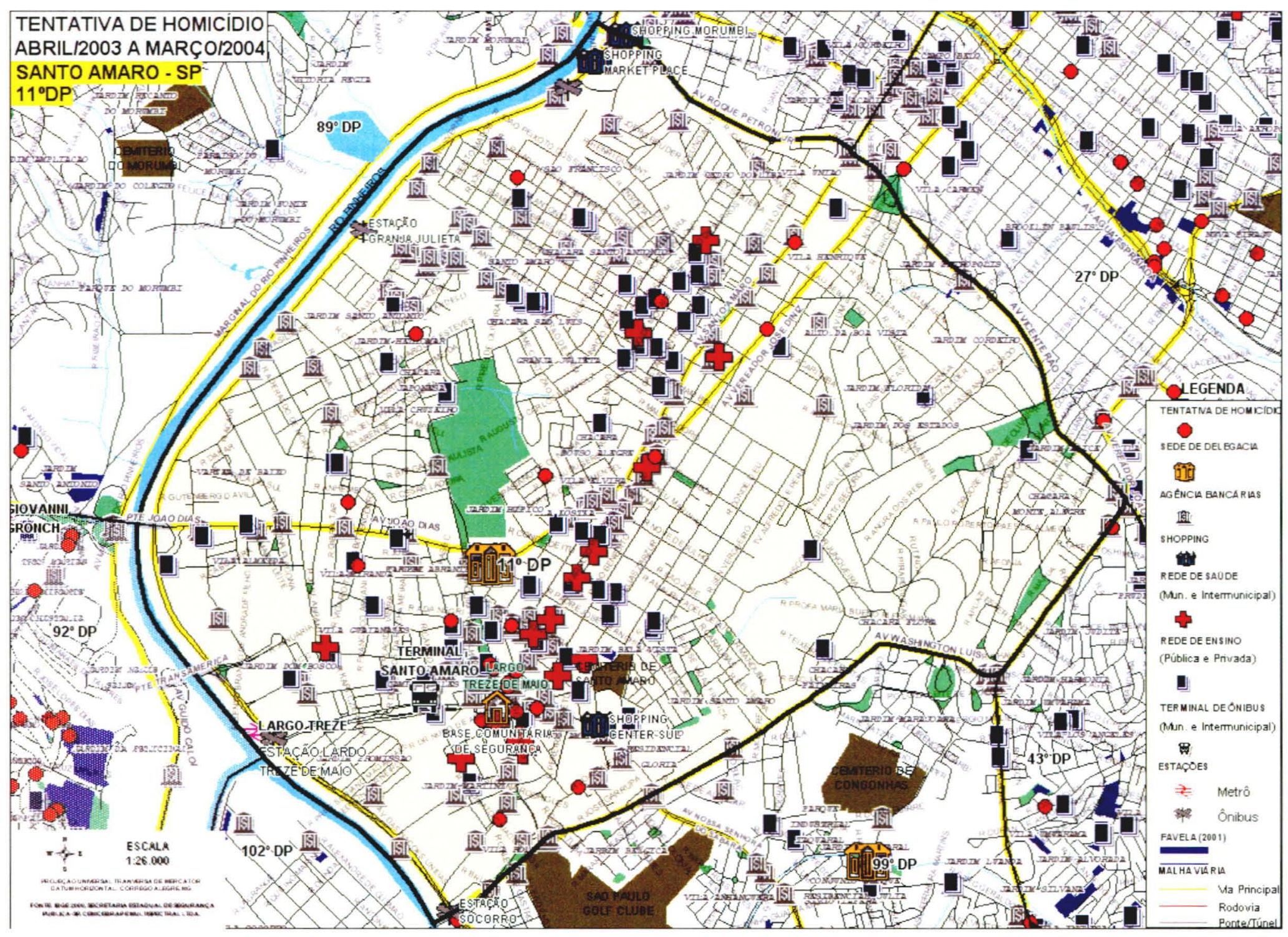

Figura 19 - Tentativa de Homicídio - Santo Amaro 


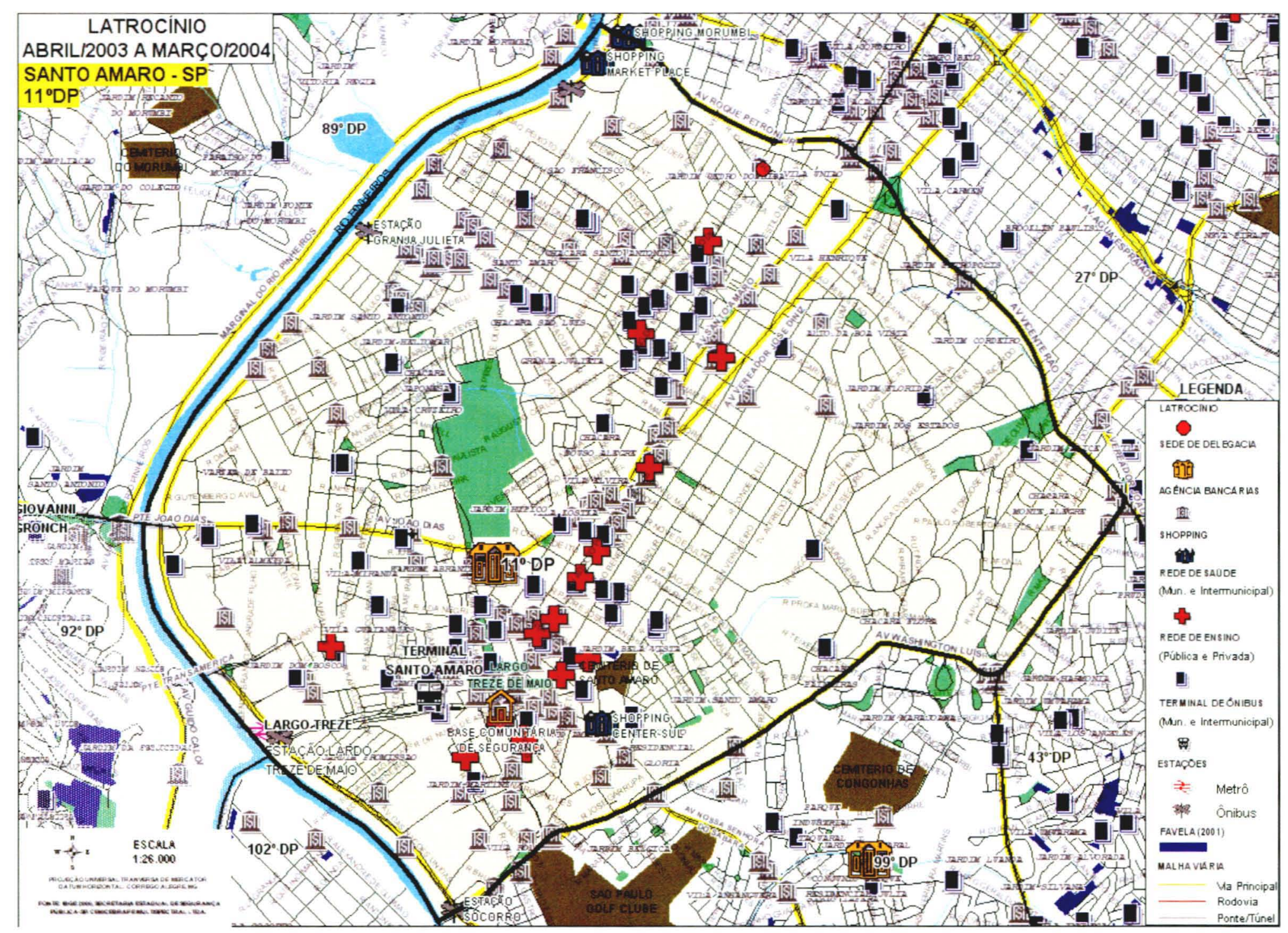

Figura 20 - Latrocínio - Santo Amaro 


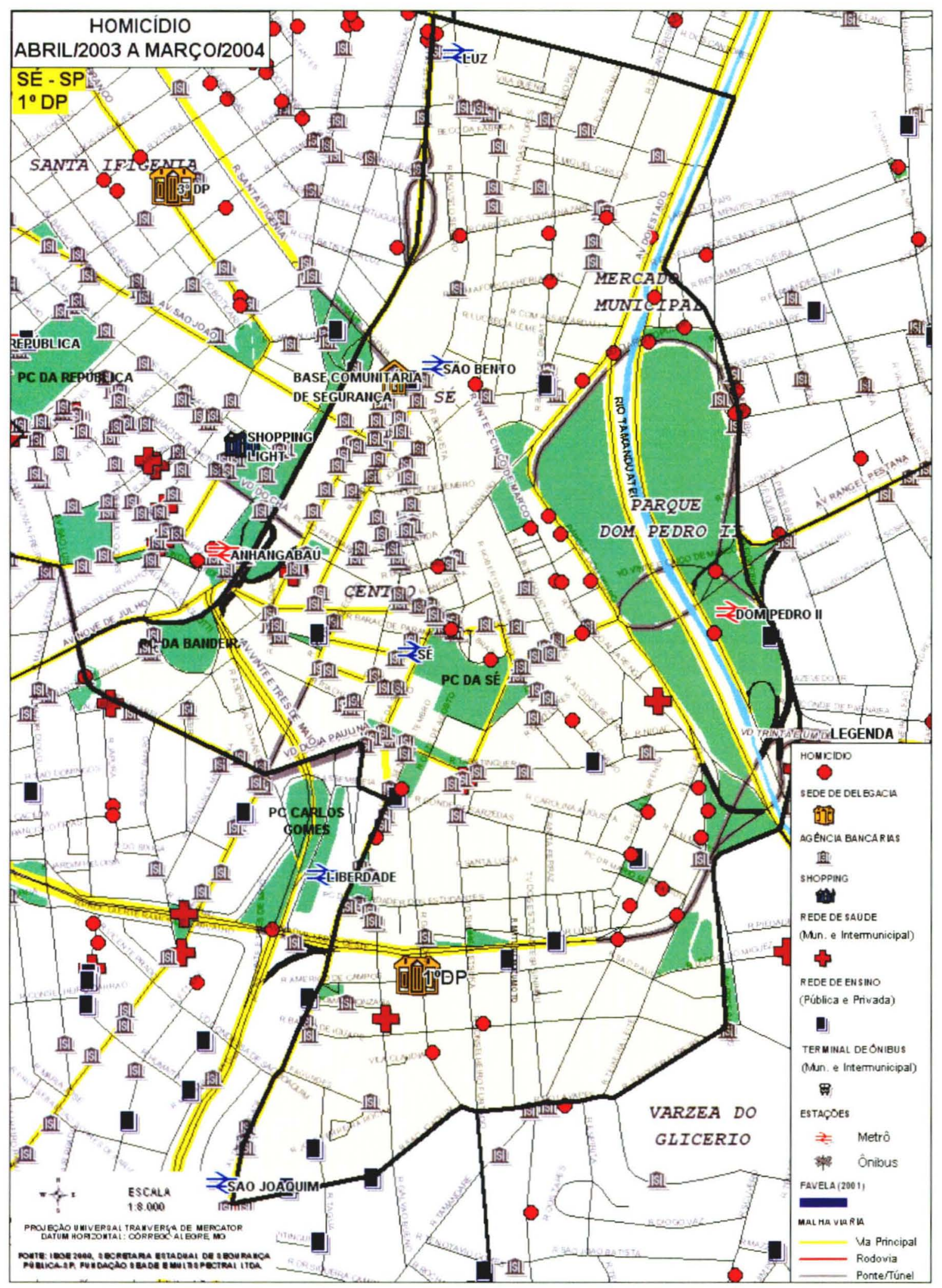

Figura 21 - Homicídio - Sé 


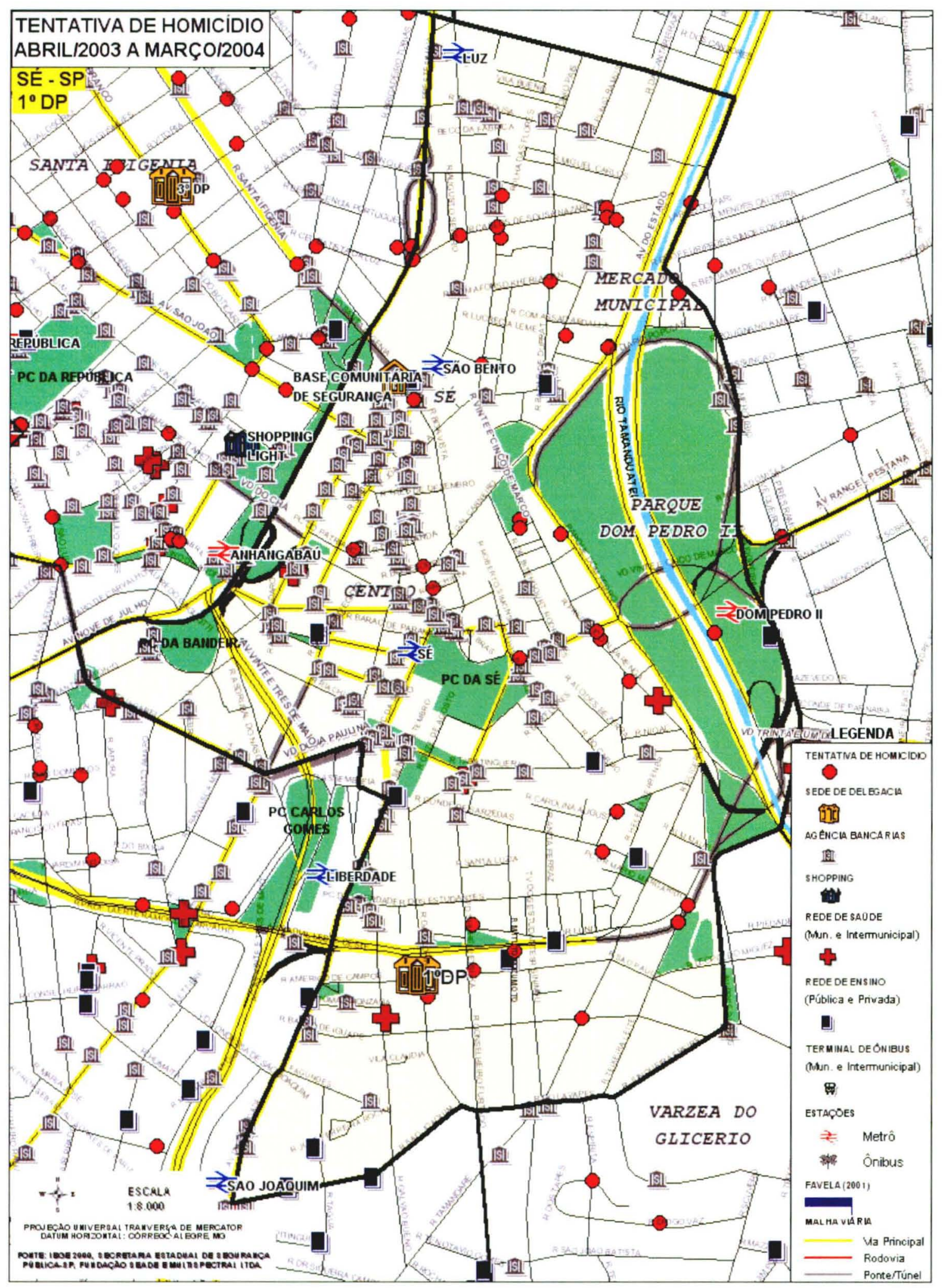

Figura 22 - Tentativa de Homicídio - Sé 


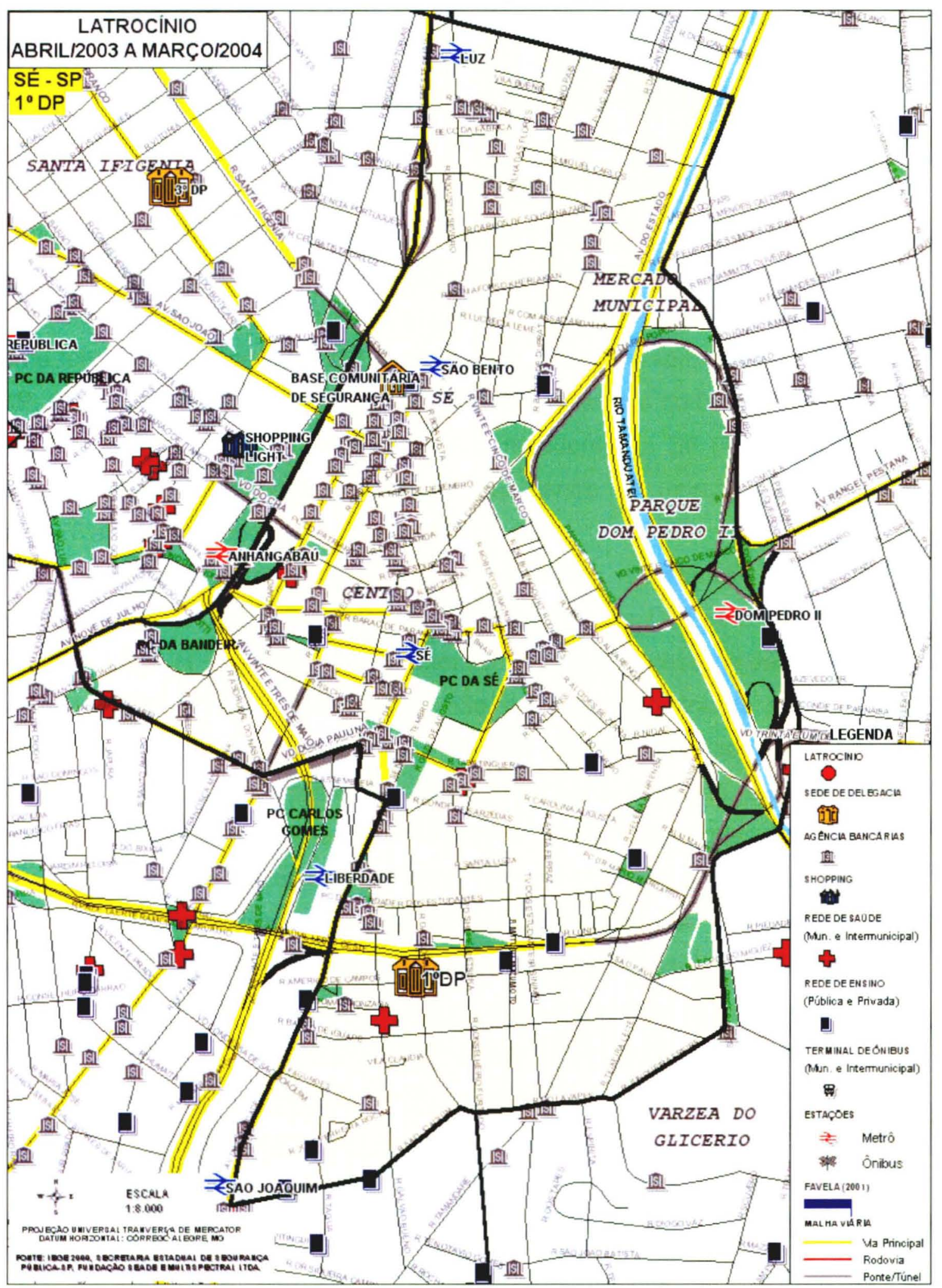

Figura 23 - Latrocínio - Sé 


\subsubsection{Distribuição dos Crimes Contra a Pessoa}

O distrito de Capão Redondo destaca-se pelo elevado número de homicídios registrados durante o período de um ano retratado no mapa. Ocorreram 217 casos de homicídios e 110 tentativas de homicídio ${ }^{38}$, distribuidos por toda área do distrito, com algumas concentrações em parques públicos. Foram registrados 2 casos de latrocínio ${ }^{39}$ no distrito, durante o período estudado.

O distrito da Sé aparece em segundo lugar em número de homicídios (42 casos) e tentativas de homicídio (37 casos). Quando se analisam dados do Pro-Aim (PMSP, 2000), que registram os óbitos por local de residência do falecido, verifica-se que a taxa de mortalidade por homicídio dos moradores da Sé (4 a 6 óbitos por 10.000 habitantes) também é mais baixa que dentre os moradores de Capão Redondo ( 6 a 8 óbitos por 10.000 habitantes).

No distrito da Sé, observa-se que os homicídios e tentativas de homicídio apresentam uma concentração maior ao redor do Parque D. Pedro, do Mercado Municipal e em Santa Efigênia, zona caracterizada por maior presença de prostituição e de usuários de drogas. Praticamente não ocorreram homicídios nos distritos bancários. Não foram registrados casos de latrocínio, durante o período, no distrito da Sé. Algumas variáveis podem explicar esses fatos: os homicidios, em geral, não parecem ter motivação econômica, pois não há latrocínios e são quase inexistentes os homicídios na zona bancária. Por outro lado, o fato das zonas bancárias não abrigarem atividades de lazer noturno e apresentarem afluxo de pessoas somente durante o dia pode explicar esse vazio de homicídios e tentativas de homicídio.

O distrito do Morumbi registrou 32 homicídios e 22 tentativas de homicídio em todo distrito, mas com concentração em favelas ou ao redor de favelas. Aí, também, parece não haver motivação econômica para os crimes. $O$ fato das áreas residenciais de maior renda do bairro não terem concentrações de homicídios pode-se dar pelos altos contingentes de segurança privada que aí atuam e, muito possivelmente, vários

\footnotetext{
38 Tentativa de Homicídio é o resultado letal, desejado pelo agente, não ocorre por circunstâncias alheias à sua vontade. (Adaptado da Resolução SSP - 160)

${ }^{39}$ Latrocínio refere-se à morte da vítima para a subtração ou tentativa de subtração de bens patrimoniais. Não é nome jurídico do Código Penal. (Adaptado da Resolução SSP - 160)
} 
desses homicidios aí ocorridos foram cometidos por agentes de segurança públicos ou privados contra jovens cometendo pequenos delitos, como furtos de toca-CDs em veículos, furtos em residências, etc. São relatadas, também, brigas entre grupos rivais fornecedores de drogas, que se abrigam nas favelas do distrito e dos arredores, como a favela Paraisópolis, a segunda maior em tamanho do município, com cerca de 60.000 moradores. O coeficiente de mortalidade por homicídio do distrito do Morumbi, segundo o Pro-Aim, foi de 4 a 6 por 10.000 habitantes (PMSP, 2000).

No distrito policial de Santo Amaro foram registrados os números mais baixos de homicídios (24 casos) e tentativas de homicídio (22 casos), quando comparados com os dos outros três distritos analisados. Aí, diferentemente das outras regiões, os homicidios e tentativas se concentraram ao longo da Av. Santo Amaro e no Largo 13, exatamente os locais de maior afluxo de pessoas e também de bares e pequeno comércio. Houve só um caso de latrocínio, no distrito. $O$ coeficiente de mortalidade por homicídio dos moradores do distrito ficou de 2 a 4 por 10.000 , no ano 2000 (PMSP, 2000).

Um elemento importante a ser levado em consideração na análise do homicídio no município de São Paulo é que os maiores índices estão concentrados nas faixas etárias de 15 a 24 anos ( $40 \%$ ou 2.477 casos em 2000 ) e de 25 a 34 anos ( $30 \%$ ou 1.813 casos em 2000). Quanto ao sexo das vítimas, $92 \%$ são do sexo masculino. (PMSP, 2000)

MINAYO (1994) aponta os jovens moradores da periferia, de baixa renda, com baixa qualificação profissional e com pouca perspectiva de inserção no mercado de trabalho formal como o grupo de maior risco de óbito por homicídio.

\subsubsection{Crimes Contra os Costumes}

A violência contra a mulher é um fenômeno que atinge diversas sociedades, mas varia na forma como é praticada (SAFFIOTI e ALMEIDA, 1995).

No Brasil, durante os anos 1980, houve forte atuação do movimento feminista para trazer à esfera pública um assunto que era visto como de âmbito privado. Como resultado, a violência contra a mulher começou a ser combatida por políticas públicas (GALVÃO E ANDRADE, 2004). Também na década de 1980, este tipo de violência 
passou a ser reconhecido pela OMS como um problema de saúde pública, pela sua dimensão e seqüelas orgânicas e emocionais que produz e o tema passou a ser estudado pela academia (GALVÃO E ANDRADE, 2004). Alguns autores sugerem que a questão deva ser analisada do ponto de vista das desigualdades de poder nas relações entre os gêneros.

O estupro ${ }^{40}$ é uma das formas de violência contra a mulher. Pesquisadores e profissionais que atuam na área de violência contra a mulher reconhecem que os dados existentes não registram a magnitude do problema, uma vez que o número de casos não notificados é grande. Estima-se que os registros das delegacias correspondam a cerca de 10 a $20 \%$ dos casos que realmente acontecem (SAFFIOTTI E ALMEIDA, 1995). Entre as causas pelas quais as vitimas hesitam em denunciar as agressōes estão: sentimentos de culpa, humilhação, medo de vingança, falta de informação sobre seus direitos legais e descrédito do sistema jurídico criminal (CAMPOS, SCHOR, ANJOS, ET AL., 2005).

Fatores como medo do agressor e vergonha da familia e da sociedade faz com que muitas mulheres deixem de denunciar seus agressores e, quando o fazem, muitas desistem de levar a denúncia adiante (GALVÃO E ANDRADE, 2004, p. 92).

Além disso, algumas mulheres agredidas não reconhecem essa situação como de violência, sobretudo quando o agressor é conhecido ou membro da família.

Pesquisa realizada na cidade de Londrina, analisando dados de 1.461 mulheres atendidas pelo Instituto Médico Legal, no ano de 1999, verificou que 65 sofreram estupro, correspondendo a $6,25 \%$ dos atendimentos (PREFEITURA MUNICIPAL DE LONDRINA, 2000 apud GALVÃO E ANDRADE, 2004).

Grossi atenta para o fato que as mulheres vítimas deste tipo de violência estão mais predispostas a apresentarem problemas psicológicos que as que não vivenciaram essa situação. As conseqüências à saúde das vítimas, apontadas por estudiosos são: violação sexual, abortos, doenças sexualmente transmissiveis, além

\footnotetext{
${ }^{40}$ Estupro: Conjunção carnal mediante violência ou grave ameaça. Penetração anal é considerada como atentado violento ao pudor. Por isso tecnicamente homens não podem ser estuprados.

(Adaptado da Resolução SSP - 160)
} 
de nervosismo, esquecimento, sentimento de insegurança e transtornos do sono (GUERRA, 1997; DINIZ E COL, 1999).

No setor saúde brasileiro, há a visão de se atender a mulher vítima de violência sexual de forma integral, saindo do limite da ação policial ou jurídica. Em 1998, o Ministério da Saúde elaborou uma Norma Técnica: "Prevenção e Tratamento dos Agravos resultantes da violência sexual contra mulheres e adolescentes", estabelecendo a formação de rede de hospitais públicos capacitados para atendimento imediato, voltado à prevenção de seqüelas físicas e psicológicas. $A$ norma estabelece que o prazo máximo para profilaxia medicamentosa seja de 72 horas após a exposição, para introduzir a medicação preventiva, mediante uso de anticoncepcional de emergência, antibioticoterapia para DSTs e quimioprofilaxia antiretroviral (CAMPOS, SCHOR, ANJOS ET AL., 2005).

Já a lei paulista de n. 10.920 de 2001 abriga as Delegacias de Polícia a informarem às vítimas de crimes contra a liberdade sexual, o direito de tratamento preventivo contra a contaminação pelo vírus HIV (SÃO PAULO, 2001).

Pesquisa realizada em Sorocaba, no período de abril de 2003 a março de 2004, tomou como referência um semestre antes e um semestre depois da implantação dessa lei, com a assinatura de um protocolo de ações integradas. Foram analisadas 235 fichas de notificação de atendimento imediato às vítimas de violência sexual no periodo, nos dois semestres. No primeiro semestre foram atendidas 42 pessoas, sendo $95,2 \%$ vítimas do sexo feminino e $4,5 \%$ do sexo masculino. No segundo semestre, houve 169 atendimentos, sendo $88,7 \%$ do sexo feminino e $11,2 \%$ do sexo masculino. Quanto às médias e medianas das idades das vítimas, os valores situaram-se entre 13 a 18 anos. Os resultados indicaram que a aplicação da lei paulista possibilitou uma maior abrangência na indicação da profilaxia das seqüelas, tanto fisicas quanto psicológicas (CAMPOS, SCHOR, ANJOS ET AL., 2005). Por outro lado, nos casos em que foi possivel a indicação do agressor foi permitido o conhecimento da sua sorologia anti HIV, o que auxiliou diminuir a indicação do uso de quimioprofilaxia anti-retroviral e da profilaxia para outras DSTs (CAMPOS, SCHOR ANJOS ET AL., 2005). 


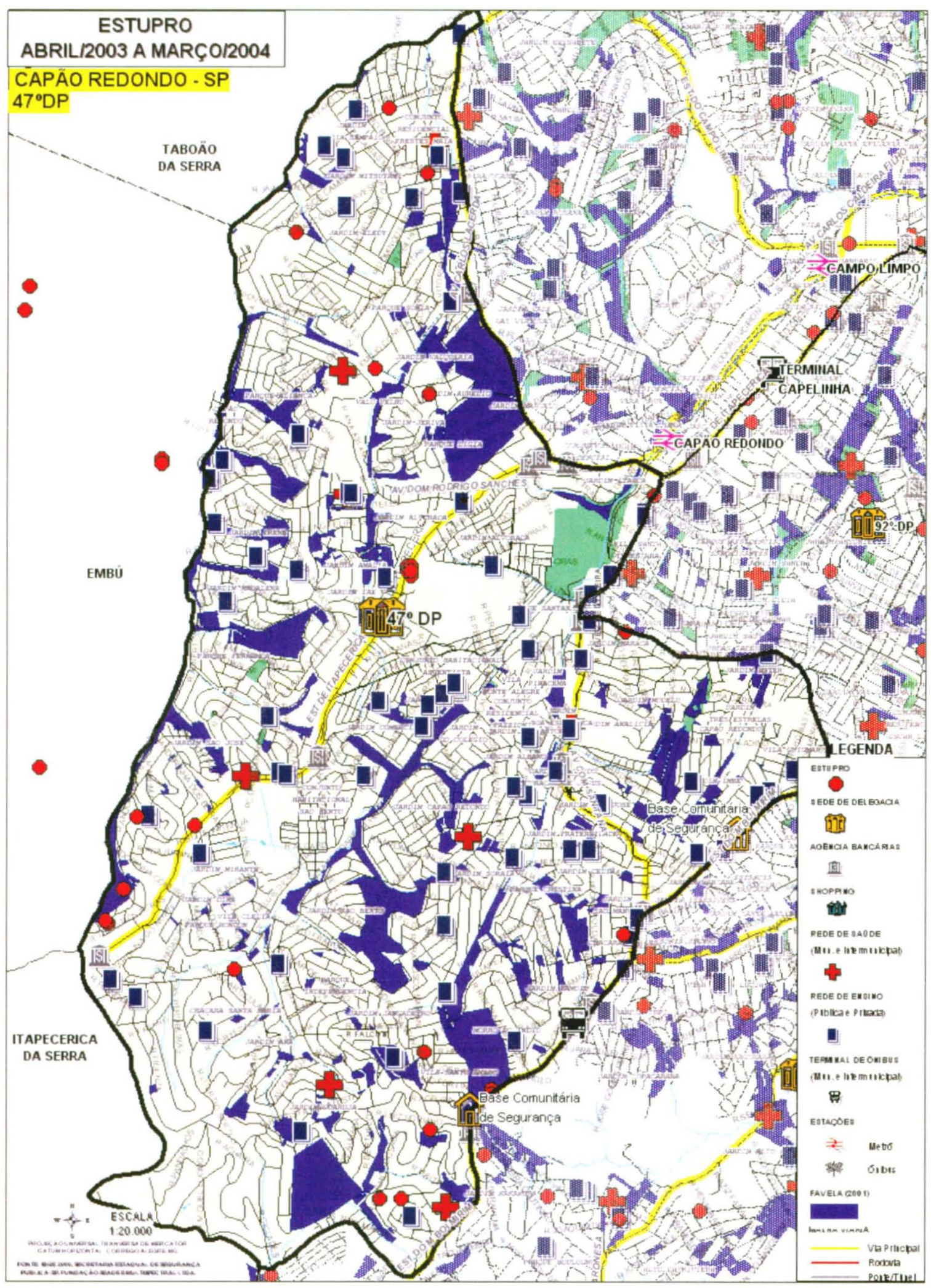

Figura 24 - Estupro - Capão Redondo 


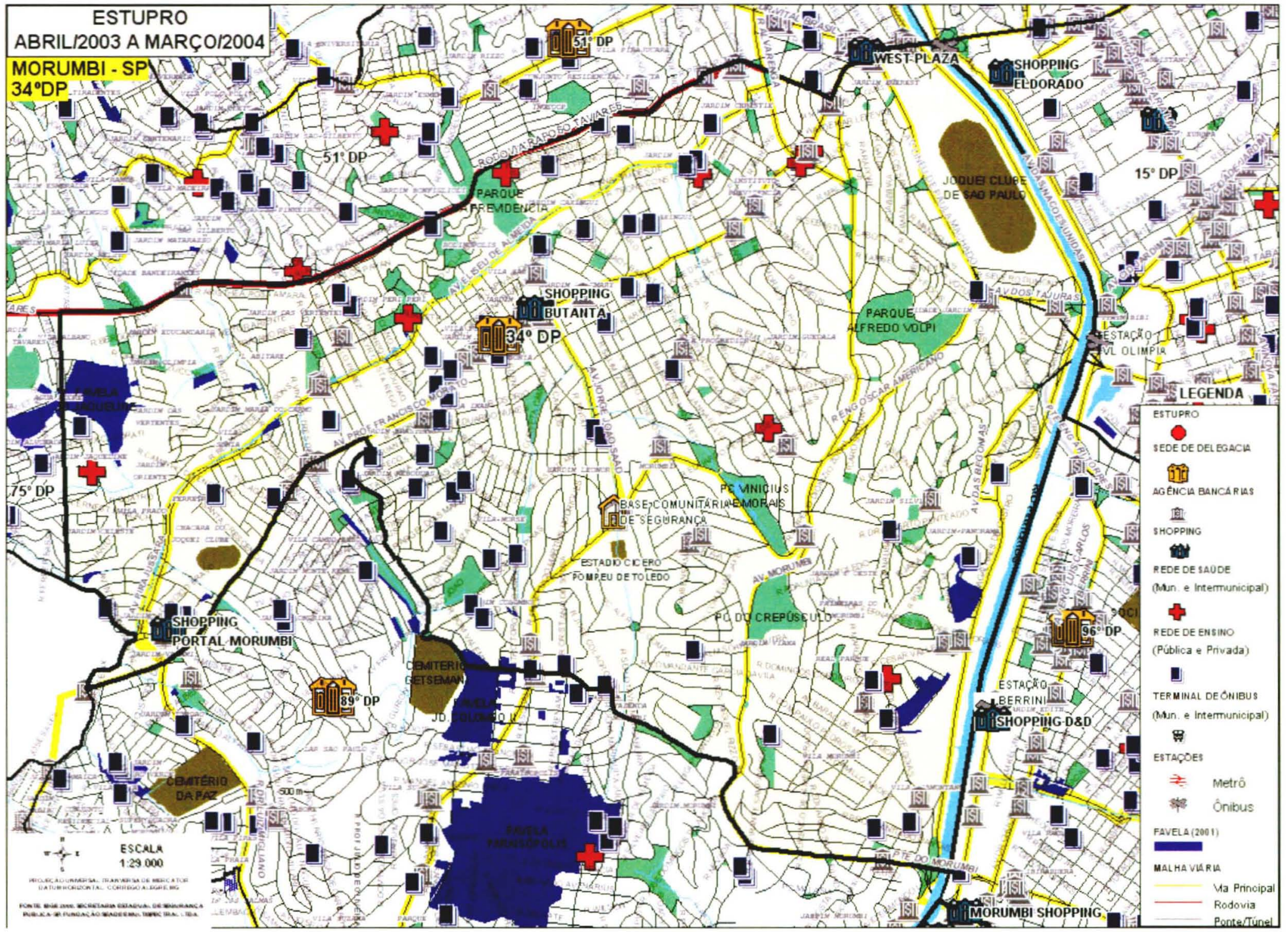

Figura 25 - Estupro - Morumbi 


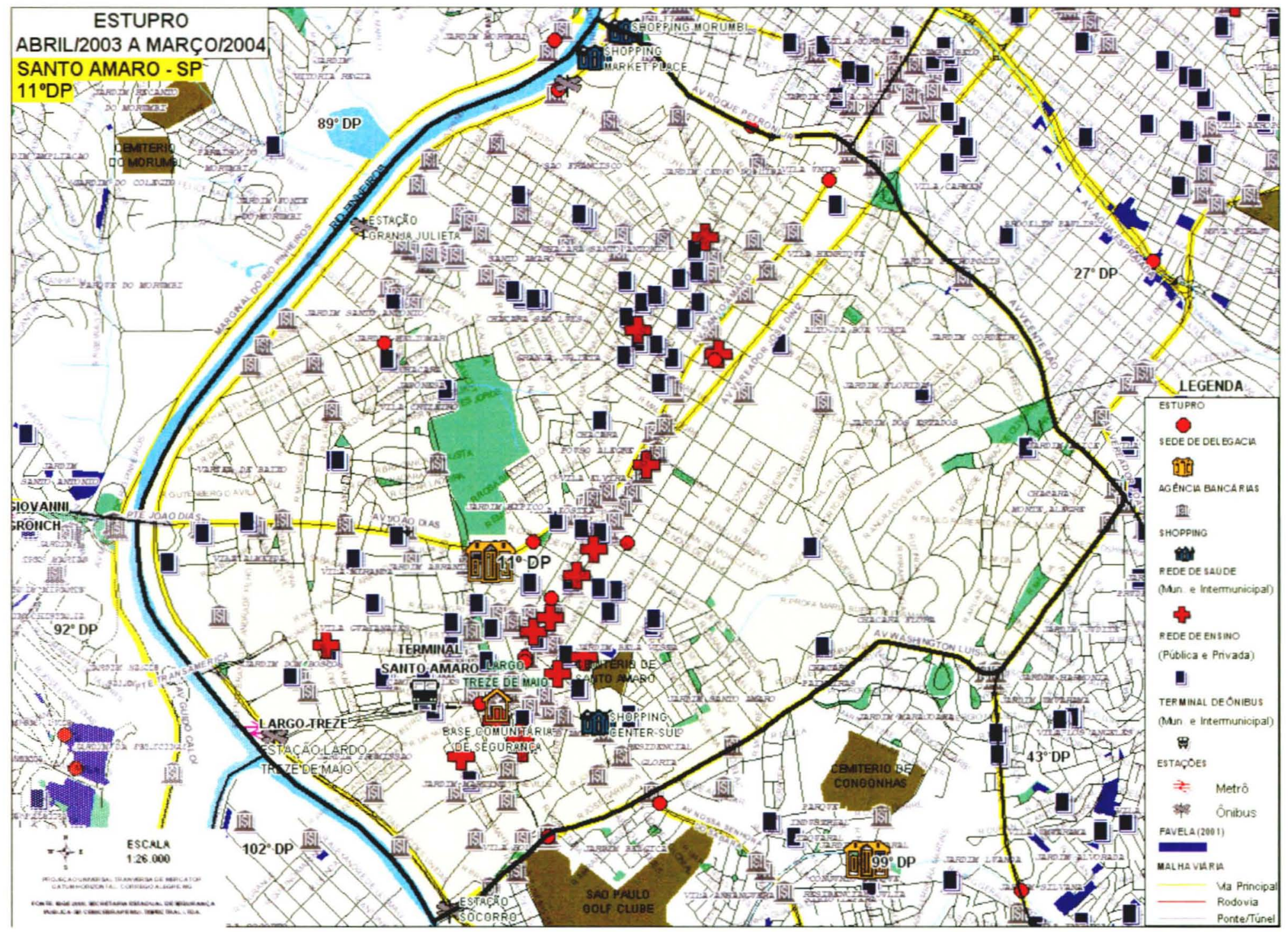

Figura 26 - Estupro - Santo Amaro 


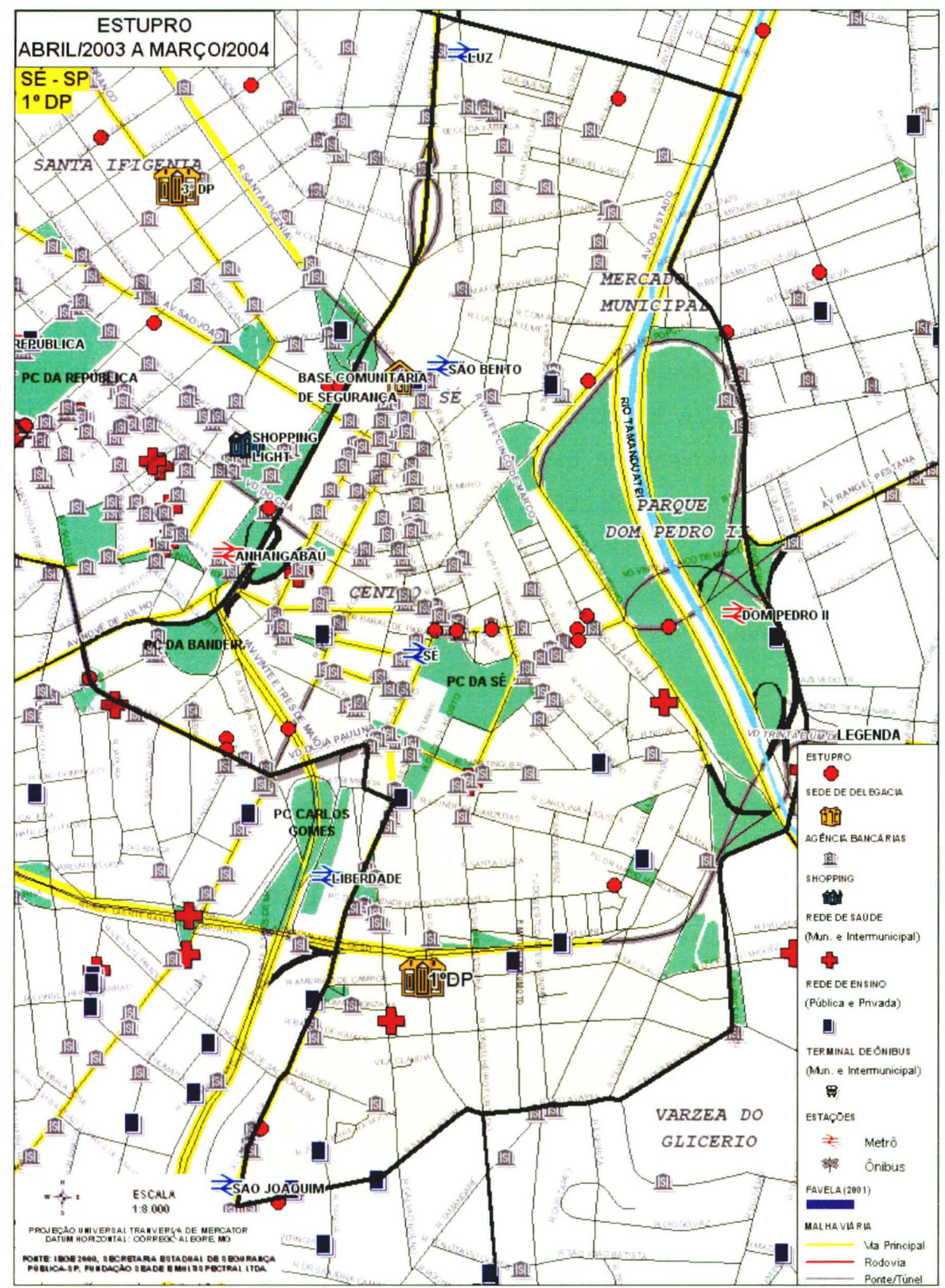

Figura 27 - Estupro - Sé 


\subsubsection{Distribuição dos Crimes Contra os Costumes}

Os casos de estupro georreferenciados também apresentaram um padrão de distribuição espacial diferenciado, de acordo com o distrito policial.

No Capão Redondo, houve 12 estupros no período de 04/2003 a 03/2004, distribuídos de forma disseminada em toda área do distrito. Tal distribuição pode se relacionar à ocupação menos adensada, com vários vazios urbanos de menor infra-estrutura e serviços, como iluminação de vias, asfalto e linhas de transporte coletivo, o que, em locais com grande freqüência de pedestres que saem de transportes coletivos para chegar às suas moradias, poderia propiciar espaços de maior risco de estupro, principalmente em regiões menos policiadas. A Organização Mundial da Saúde já alertava para o fato de como a pobreza exacerba a vulnerabilidade de mulheres e meninas. Ao desenvolver suas atividades diárias, como voltar para casa à noite, em áreas economicamente desfavorecidas, elas correm alto risco de estupro (WORLD HEALTH ORGANIZATION, 2002)

No Morumbi houve 5 estupros no período, distribuídos no distrito, mais 5 estupros concentrados na Favela Paraisópolis, nos limites do distrito. No caso, fatores como baixa densidade de pessoas, ruas mal iluminadas e pouco policiamento poderiam explicar a distribuição espacial.

No distrito de Santo Amaro, a distribuição já difere bastante do padrão encontrado nos dois distritos descritos anteriormente. Os 8 estupros ocorridos, no período, ocorreram ao longo, ou muito próximos, da Av. Santo Amaro. A avenida é um corredor de transportes coletivos, dos mais importantes da cidade, que dá acesso a inúmeros bairros de população operária e de habitações populares. $O$ grande volume de mulheres, sobretudo jovens, que circulam a pé nas suas redondezas e a deficiente ação da polícia podem explicar essa concentração de estupros.

No distrito da Sé, os casos de estupro foram bem mais abundantes que nas outras três áreas: 22 casos no período. Há uma distribuição generalizada na área do distrito, mas nota-se uma concentração ao redor das praças 
públicas: Sé, República e Anhangabaú. Estes espaços atraem jovens que vivem nas ruas, além de constituírem, à noite, áreas mais escuras e com menos presença de pessoas.

Como já mencionado em outro ponto deste trabalho, o mapa não explica nada, mas ele dá pistas para possiveis explicações com o aprofundamento das análises. Seria necessário o prosseguimento destes levantamentos, com verificação de dados sobre dia da semana e horário em que esses episódios ocorreram, para que se possam traçar estratégias mais adequadas para seu enfrentamento.

\subsubsection{Crime contra o Patrimônio}

Dentre os crimes contra o patrimônio, optou-se por mapear os roubos, por razões descritas na metodologia. Na categoria roubo, foram mapeados alguns tipos de roubo, por constituirem formas diferenciadas de agressão. Consideramos que seus efeitos à saúde são predominantemente indiretos, diferentemente das outras categorias analisadas previamente, homicidio, latrocínio e estupro, que afetam diretamente os indicadores de saúde pública.

O roubo significa subtração de bem patrimonial acompanhada de ameaça física e/ou moral. Difere do furto que é a subtração de um bem patrimonial, sem ameaça a seu portador ou proprietário. Por conta do enfoque deste trabalho estar relacionado à saúde pública, optou-se por trabalhar somente com a categoria de crime contra o patrimônio.

Como efeitos indiretos dos roubos, destacamos aqueles apontados pela WHO (2004), já mencionados na introdução deste trabalho: conseqüências psicológicas e físicas das agressões e isolamento por causa do medo.

Também Carrera Fernandez e Pereira (2002) destacam que dados da Secretaria de Segurança Pública do Estado de São Paulo, com base em séries mensais de ocorrências policiais, no periodo de janeiro de 1985 a 1993, indicam que $65 \%$ do total de crimes contra o patrimônio, na Região Metropolitana de São Paulo constituem furto, roubo e furto e roubo de veículos. Os autores acima 
citados aplicaram um modelo "econométrico" a estes dados e verificaram que os índices para estes tipos de crimes correlacionaram-se com a concentração de renda e o desemprego de forma positiva, enquanto que a correlação com o rendimento médio da população, a eficiência da polícia e da justiça foi negativa. Concluíram, a partir de sua pesquisa, que as variáveis sócio-econômicas são mais efetivas no combate ao crime que o policiamento e a justiça e, portanto, políticas de redistribuição de renda são essenciais para gerar ambientes mais seguros, ao lado de ação eficiente da polícia e da justiça.

Corroboraram seus estudos com teorias econômicas do crime que têm como base modelos que adotam como pressuposto que os índices de criminalidade dependem de um conjunto de variáveis explicativas independentes: taxa de desemprego, índice de concentração de renda, rendimento médio do trabalho, eficiência da polícia e eficiência da justiça.

Discutindo cada uma destas variáveis, Carrera-Fernandez e Pereira (2002), sintetizaram:

1. A despeito de não haver ainda um consenso na literatura internacional, muitas evidências de estudos científicos sugerem que o efeito da taxa de desemprego sobre a criminalidade é positivo.

2. Estudos realizados nos EUA evidenciaram que salários mais altos tendem a reduzir o número de detenções ou condenações relacionadas a crimes contra o patrimônio.

3. Poucos estudos econométricos existentes indicam que quanto maior for a desigualdade de renda, maiores serão os índices de criminalidade.

4. A eficiência da polícia, medida pelo número de crimes contidos ou solucionados através de investigação ou prevenção, representa a probabilidade de detenção de um criminoso. Relatam que nos EUA, há estimativas que jovens são detidos a cada 6 roubos realizados. $\mathrm{Na}$ Região Metropolitana de São Paulo, consideram que a atuação truculenta da polícia não conseguiu controlar 0 avanço da criminalidade. 
5. Não tem sido registrada uma redução acentuada da criminalidade em resposta ao aumento do número de condenações e aprisionamentos em diferentes países.

Já Sorre (1984, P. 61 e 62) afirmava que, nas metrópoles, fatores como a alta mobilidade, o anonimato das relações, a impessoalidade dos controles sociais, todas as facilidades dadas aos delinqüentes para que se associem criam um clima favorável ao desenvolvimento de tipos de criminosos sociais. Defende a idéia que o complexo socioeconômico dos diferentes distritos de uma aglomeração reflete-se na sua patologia mental, o que resulta em distribuição espacial diferenciada de tipos de crimes conforme a variabilidade do referido complexo (SORRE apud MENDONÇA, 2001).

Entretanto, como afirma Monteiro (2001, prefácio), quando focalizamos "criminalidade" temos que fazer face a uma complicada trama na qual se mesclam componentes psicológicos, sociais, econômicos, etc. etc., o que aconselha cautela e muito cuidado no trato científico do problema.

Em nosso estudo, foram mapeados os tipos de roubo que apareceram com maior freqüência no período de 04/2003 a 03/2004: roubo à residência ${ }^{41}$, roubo a transeunte ${ }^{42}$, roubo a interior de veículo ${ }^{43}$ e roubo de veículo ${ }^{44}$, por serem os mais freqüentes e consequentemente gerarem agressão à vítima. $A$ descrição e discussão que fazemos a seguir sugerem algumas interpretações, mas estão longe da pretensão de esgotar a complexidade do problema.

\footnotetext{
${ }^{41}$ Roubo à Residência: Subtração de bens patrimoniais guarnecidos no imóvel. (Adaptado da Resolução SSP - 160)

${ }^{42}$ Roubo a Transeunte: Subtração de bem patrimonial de quem transita a pé por logradouro público. (Adaptado da Resolução SSP - 160)

${ }^{43}$ Roubo a Interior de Veículo: Inclui qualquer veículo automotor (carro, moto, caminhão, ônibus, etc.) Quando alguma peça ou acessório é subtraído isoladamente. (Adaptado da Resolução SSP - 160)

44 Roubo de Veículo: Inclui qualquer veículo automotor (carro, moto, caminhão, ônibus, etc.) Quando o velculo é subtraido e não alguma peça ou acessório isoladamente. (Adaptado da Resolução SSP - 160)
} 


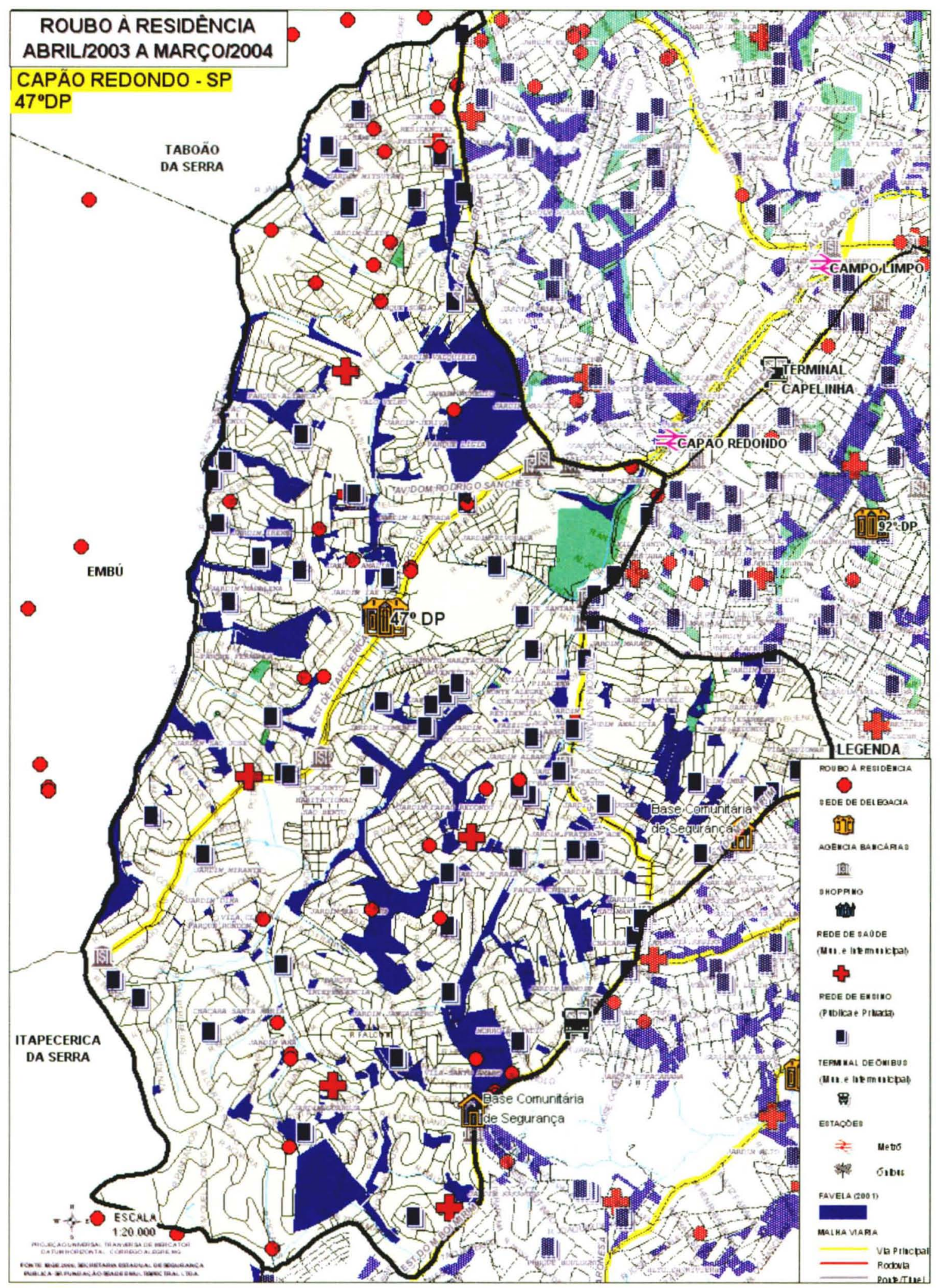

Figura 28 - Roubo à Residência - Capão Redondo 


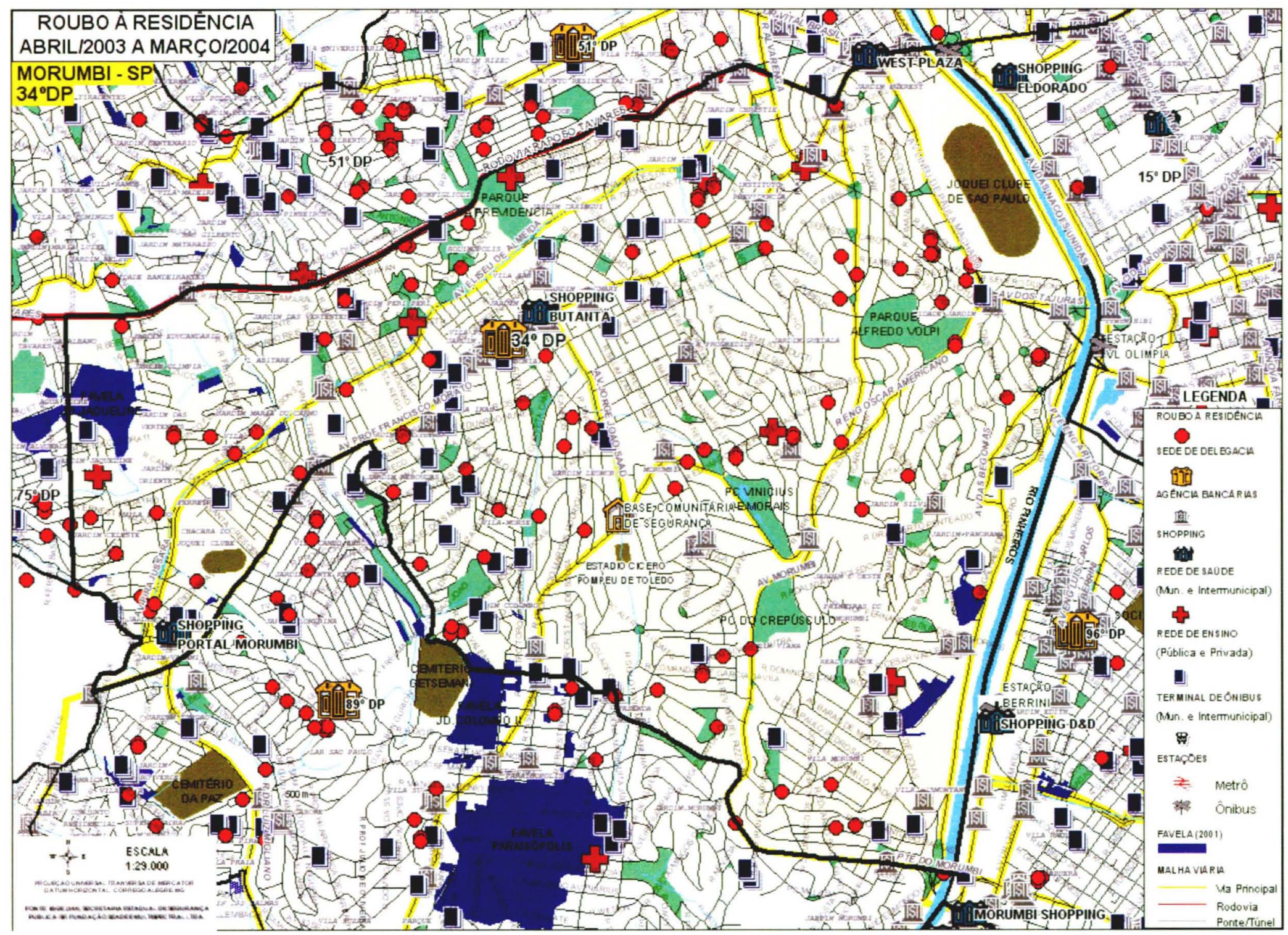

Figura 29 - Roubo à Residência - Morumbi 


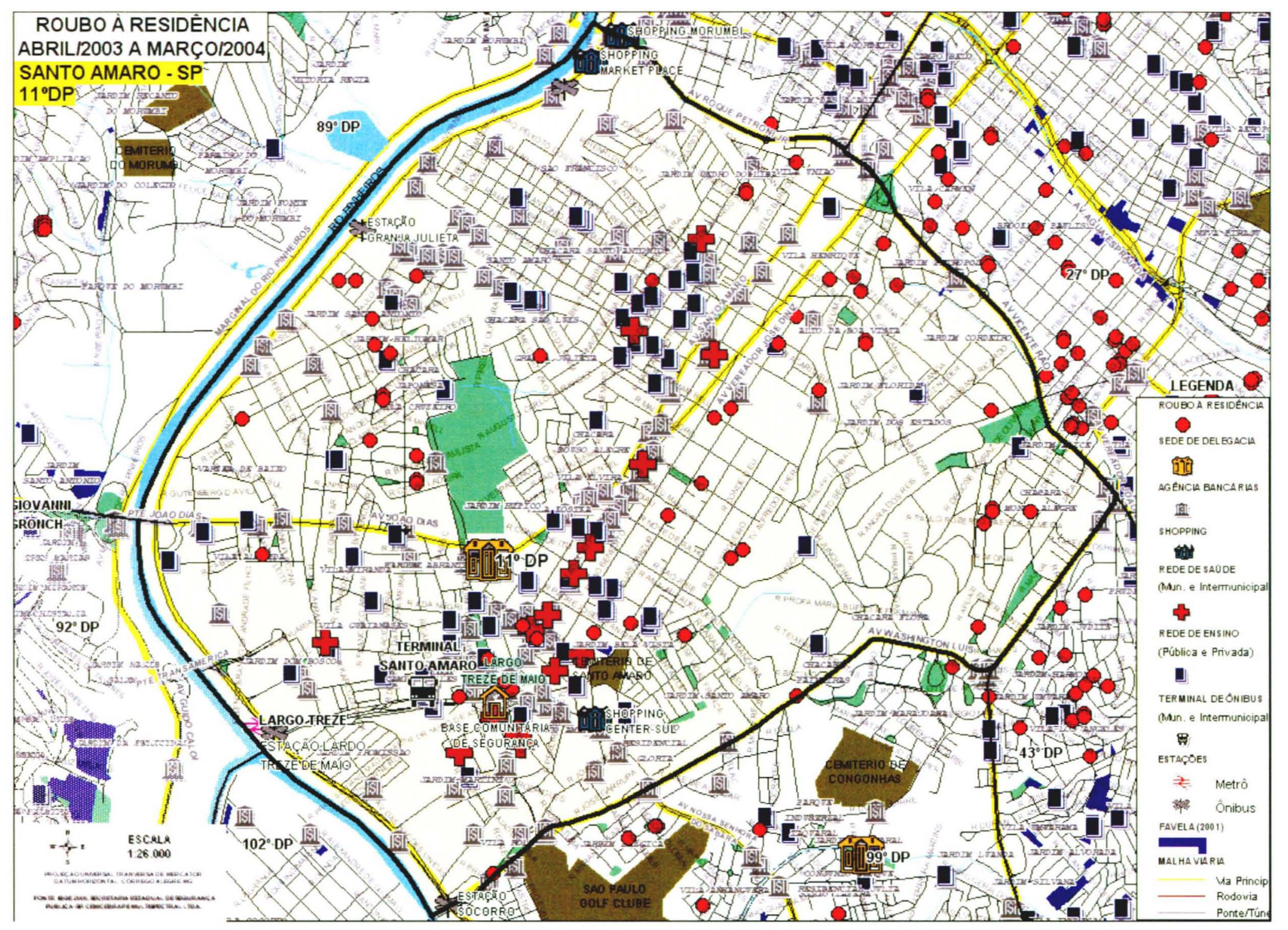

Figura 30 - Roubo à Residência - Santo Amaro 


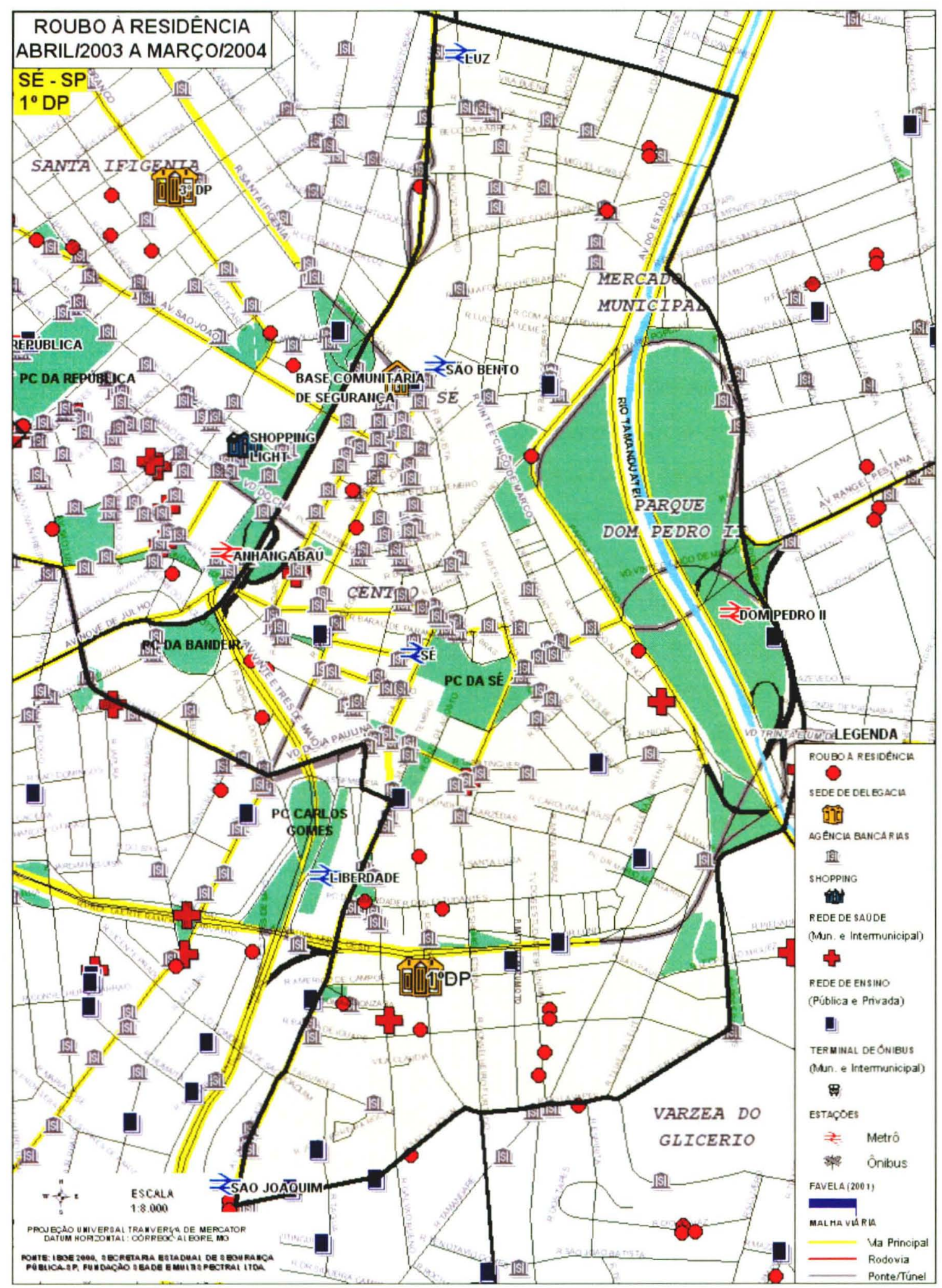

Figura 31 - Roubo à Residência - Sé 


\subsubsection{Distribuição dos Crimes Contra o Patrimônio}

A distribuição espacial dos roubos também é diferenciada, dependendo do tipo de roubo e das características do bairro analisado.

- Roubo à Residência

Há um número bem mais expressivo no Distrito Policial do Morumbi: cerca de 16 vezes superior aos números de Capão Redondo, levando em conta o número de domicílios (IBGE 2000), seguido de Santo Amaro e da Sé. O Morumbi, por ser um bairro de fortes contrastes sócio-econômicos, com residências de altíssimo padrão ao lado de numerosas favelas, com grandes contingentes de jovens e adultos desempregados e com poucas condições de arrumar trabalho remunerado, ao lado da facilidade de se ocultar ou de ocultar o produto do roubo nas favelas, onde a presença da polícia era rara ou eventual, parece propiciar as condições mais favoráveis a este tipo de crime. Somente nas áreas do distrito com mais forte contingente de segurança privada, como Jardim Guedala, Cidade Jardim e Paineiras do Morumbi, não houve casos de roubo à residências.

O Capão Redondo é o distrito que apresentou o menor número de ocorrências pelo número de domicílios. Por ser um bairro com maior homogeneidade no padrão residencial de renda, mais baixa, há menor motivação econômica para roubo à residências.

Os Distritos de Santo Amaro e da Sé representaram, respectivamente, o segundo e terceiro lugares com relação ao número de roubos à residência (sempre levando em conta o número de domicilios do Distrito considerado). $\mathrm{Na}$ Sé, a presença maior de casos foi em Santa Efigênia e na Liberdade, que constituem "sub-áreas" com maior predominio de uso residencial do que o restante da região. Em Santo Amaro houve maior número próximo à Av. Santo Amaro e à Marginal Pinheiros, possivelmente por constituirem rotas de fuga dos criminosos. 


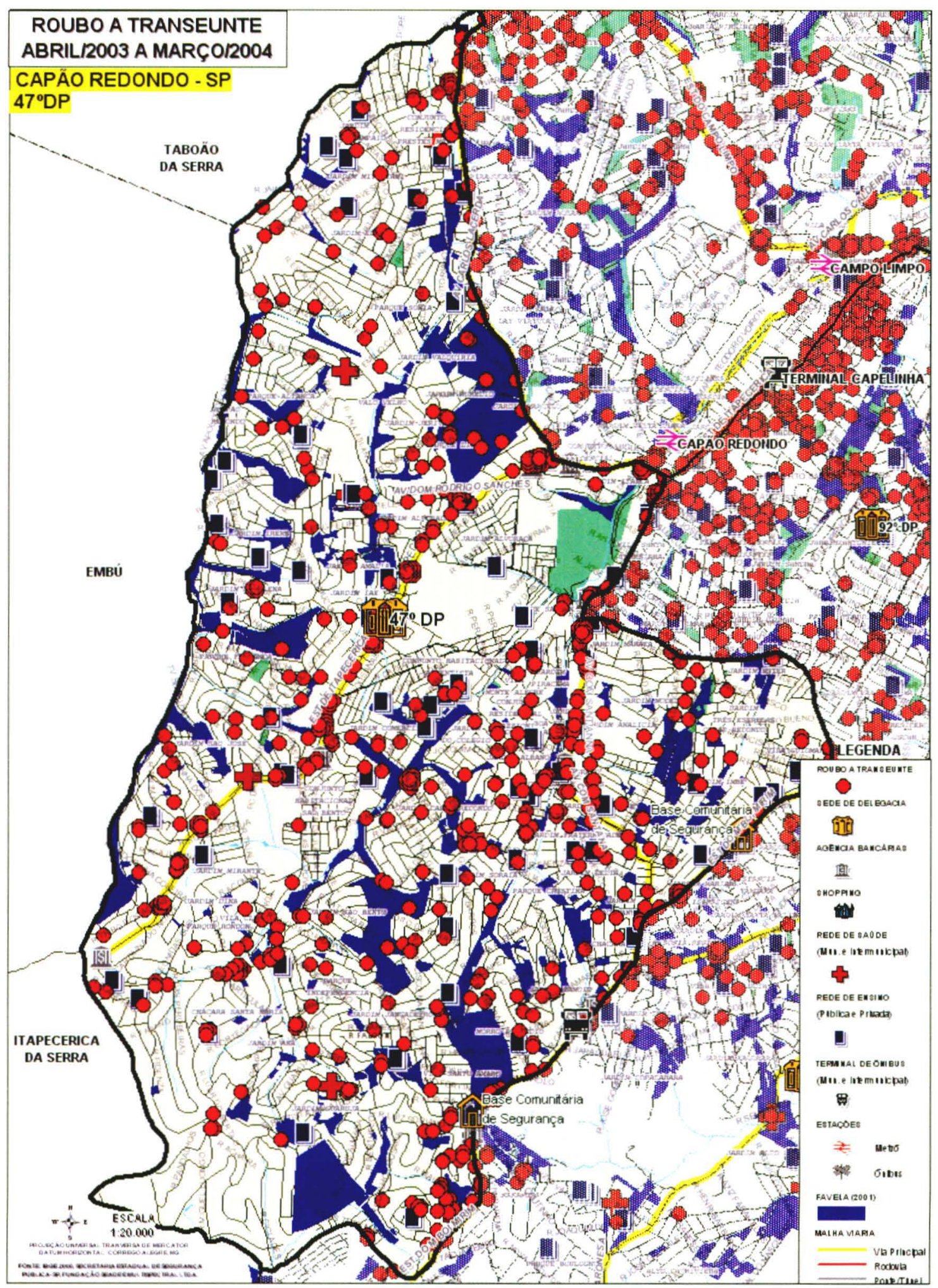

Figura 32 - Roubo a Transeunte - Capão Redondo 


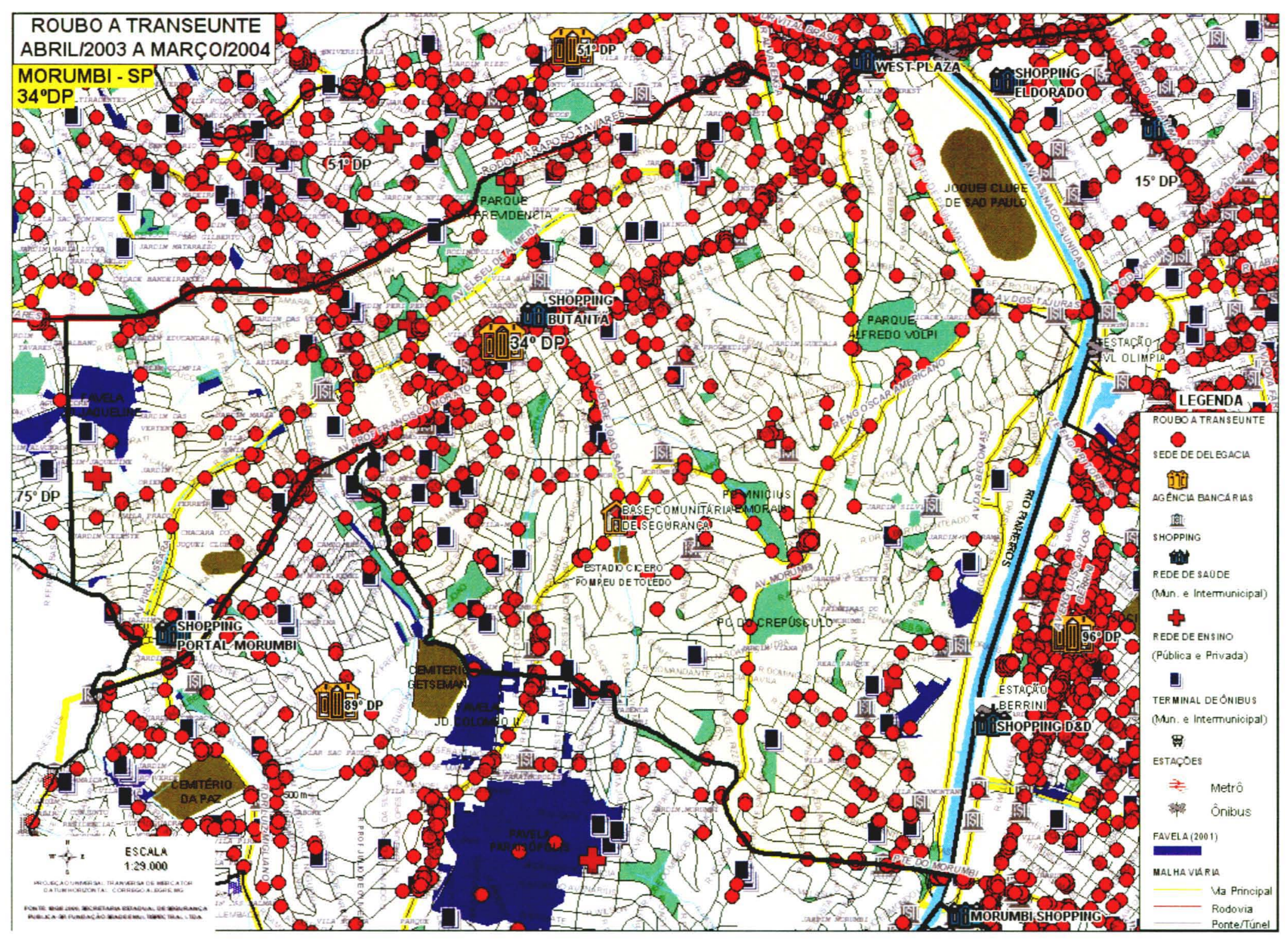

Figura 33 - Roubo a Transeunte - Morumbi 


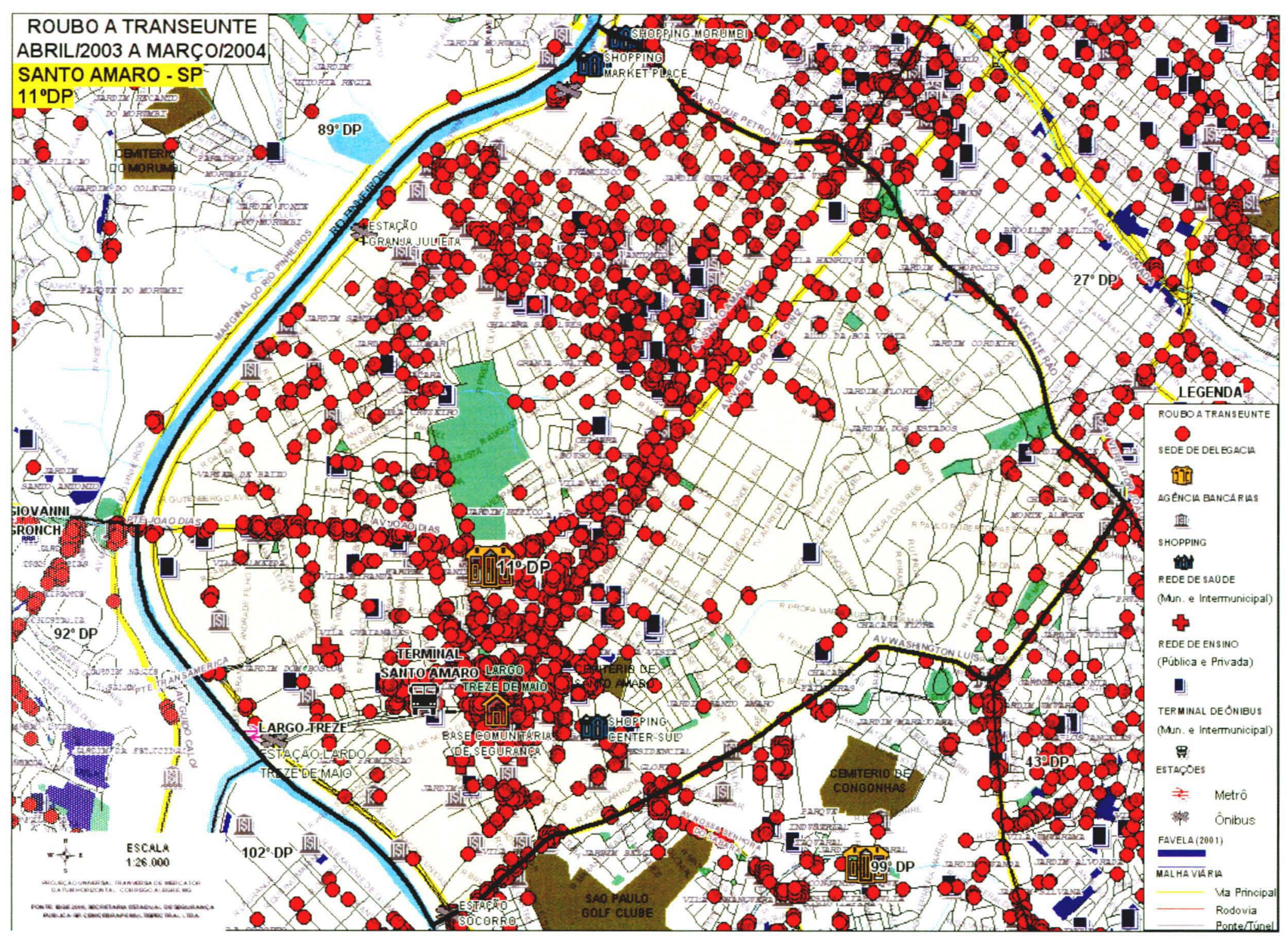

Figura 34 - Roubo a Transeunte - Santo Amaro 


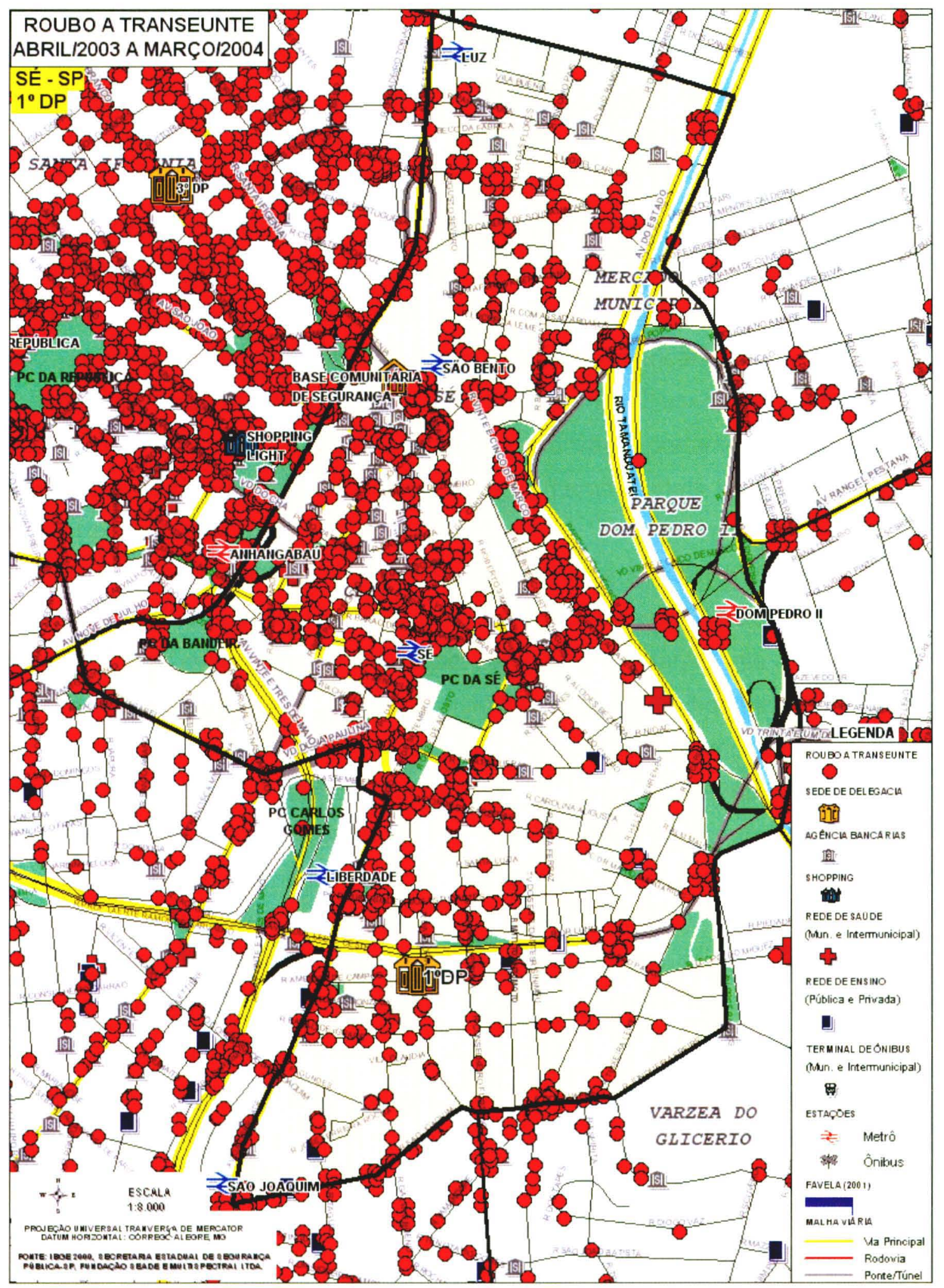

Figura 35 - Roubo a Transeunte - Sé 
-Roubo a Transeunte

Apresenta números bem mais elevados que o roubo à residência, nos quatro distritos.

O Distrito do Capão Redondo, sendo aquele de população de menor renda, teve casos disseminados por todo o distrito, mas em quantidades menores (797 ocorrências) que os outros três distritos analisados.

O Morumbi teve mais casos (820 ocorrências), mas concentrados ao longo das avenidas que cortam o distrito: Avenida Francisco Morato, Avenida João Jorge Saad, cruzamento da Avenida Oscar Americano com Avenida Morumbi e Avenida Morumbi próximo à ponte Morumbi. Ë um bairro em que a população de maior renda circula sobretudo motorizada, portanto os roubos a transeuntes se dão em alguns pontos onde há paradas mais importantes de transportes coletivos.

O Distrito de Santo Amaro apresentou números altíssimos de roubos a transeuntes (2433 ocorrências), sobretudo ao longo dos corredores de ônibus: Avenida Santo Amaro, Avenida João Dias, Largo 13 e Chácara Santo Antônio.

Sé foi o distrito que apresentou números altos de roubo a transeuntes (1806 ocorrências), mas bem distribuídos, o que quase impossibilitou a visualização dos equipamentos urbanos, pois os pontos se sobrepunham uns aos outros. Em praticamente todas as ruas do distrito, os números são expressivos. Principalmente ao redor da Praça da República, da Praça da Sé e do Parque D. Pedro, ainda são mais altos.

É importante ressaltar que muitas das ruas do Distrito Policial da Sé são fechadas para automóveis particulares, outras só permitem trânsito reduzido. Por outro lado, por constituir-se no centro histórico da cidade há aí muitas funções públicas que atraem um fluxo grande de pessoas, muitas de padrão sócio-econômico médio/alto, que circulam a pé pelas ruas, geralmente com suas larguras reduzidas devido a grande disputa das calçadas pelo comércio informal, o que facilita a ação de criminosos. 


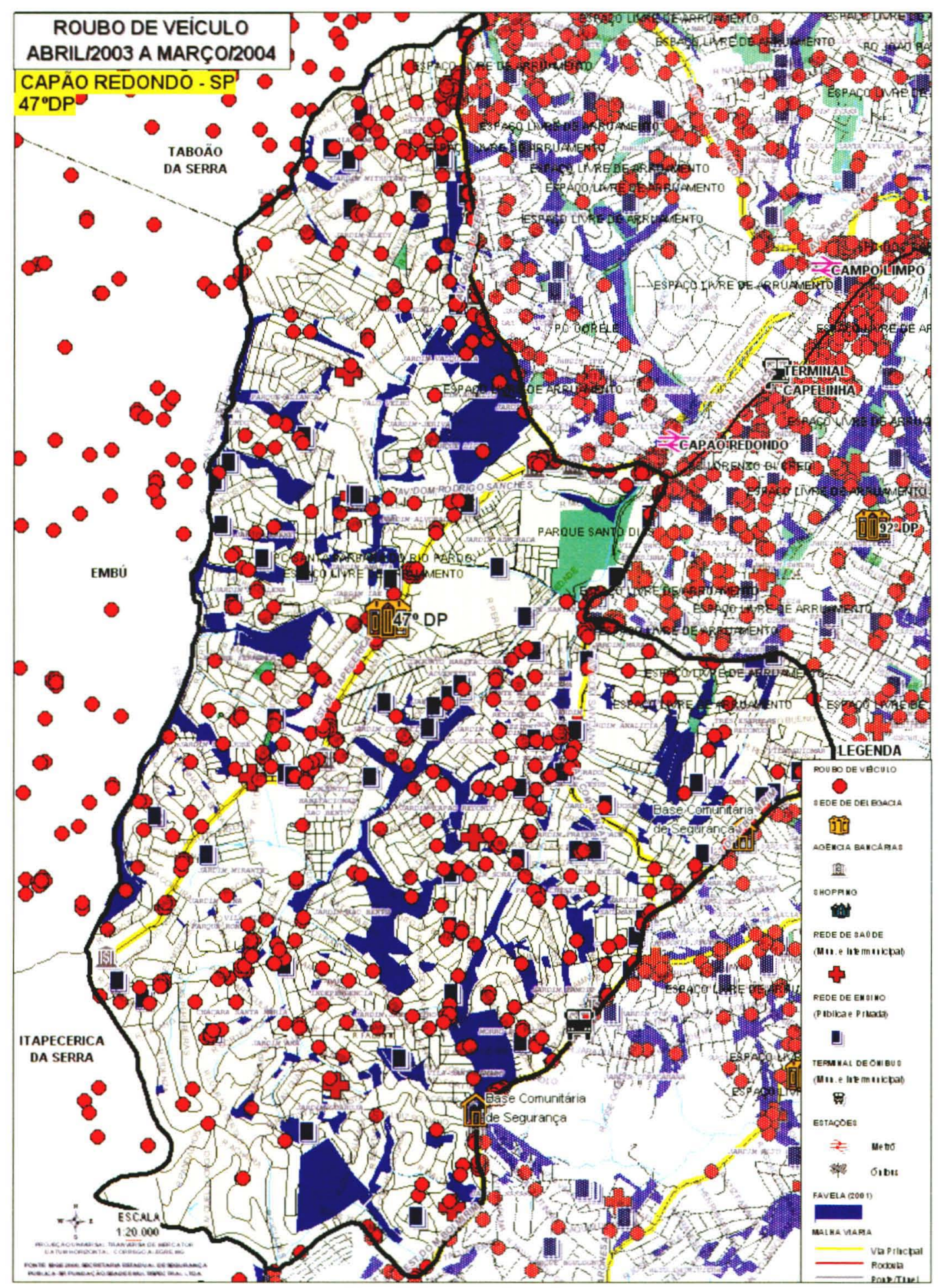

Figura 36 - Roubo de Veículo - Capão Redondo 


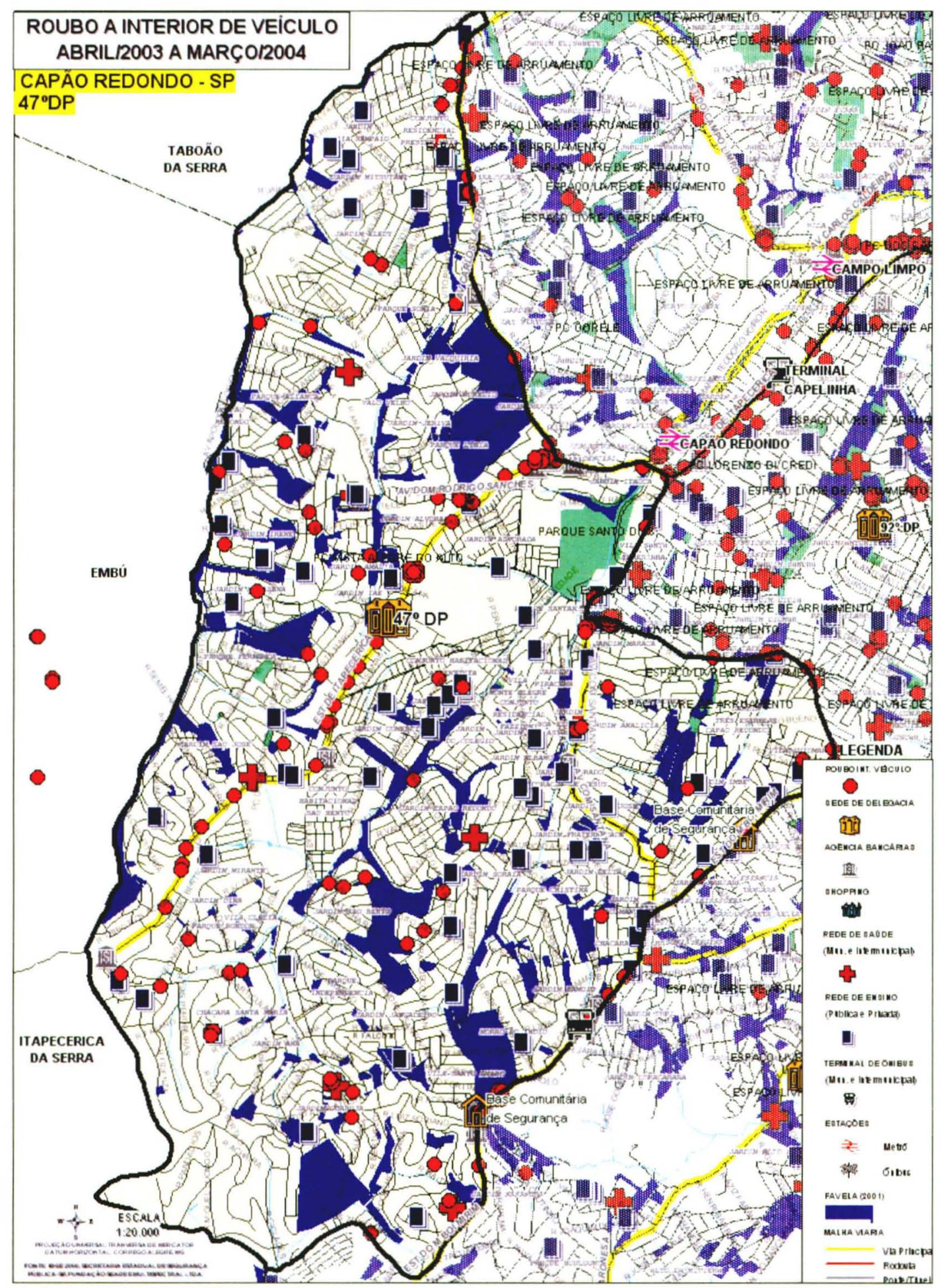

Figura 37 - Roubo a Interior de Veículo - Capão Redondo 


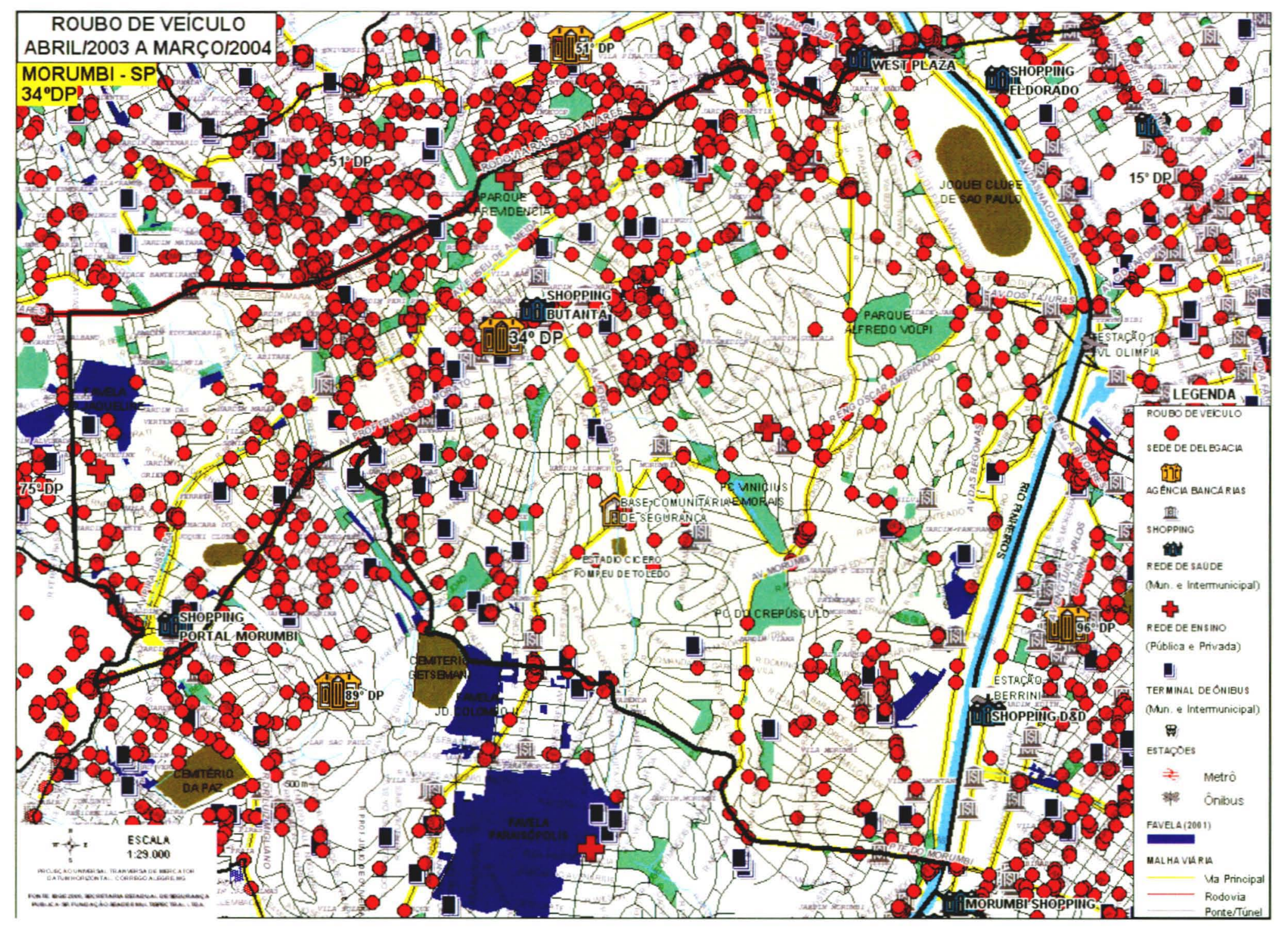

Figura 38 - Roubo de Veículo - Morumbi 


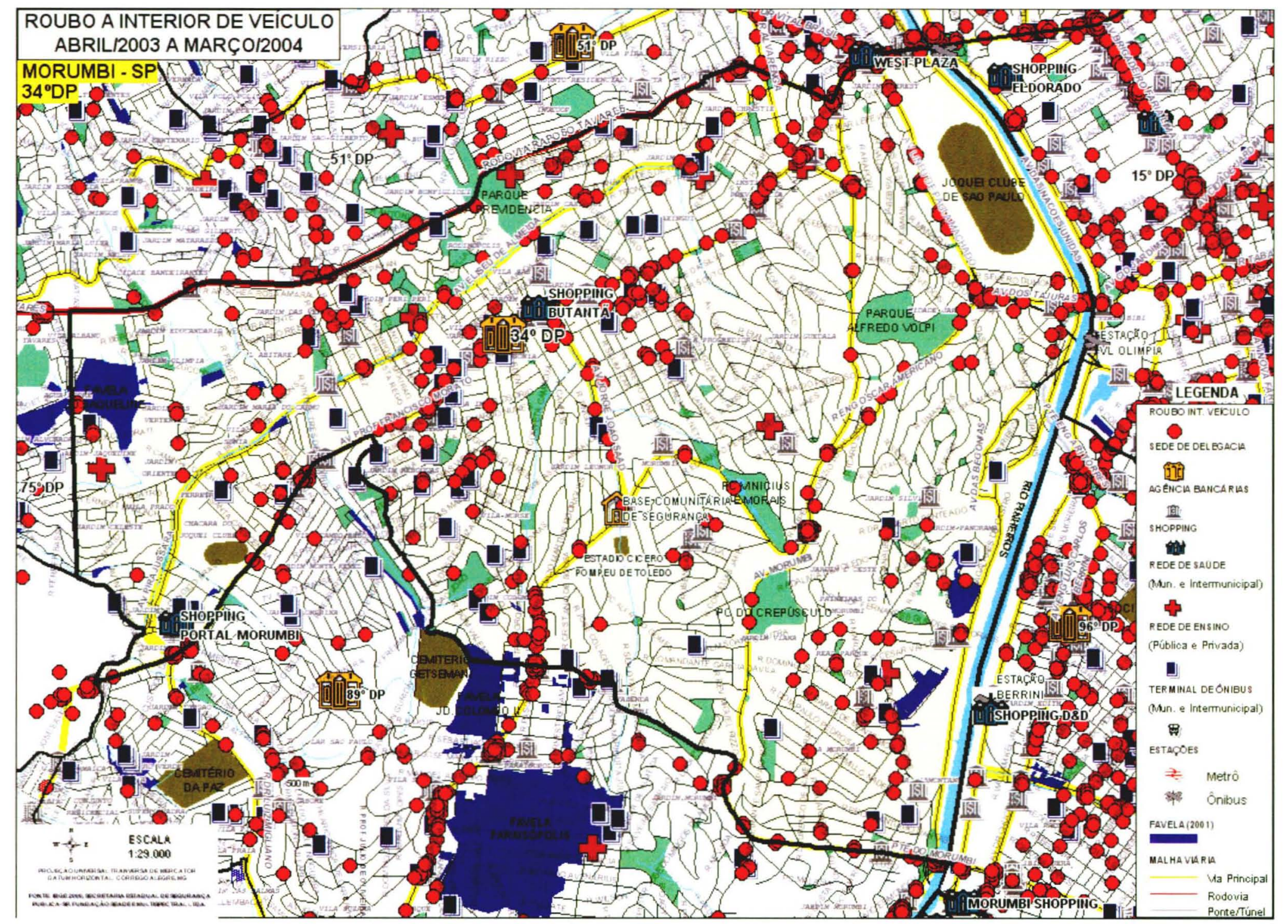

Figura 39 - Roubo a Interior de Veículo - Morumbi 


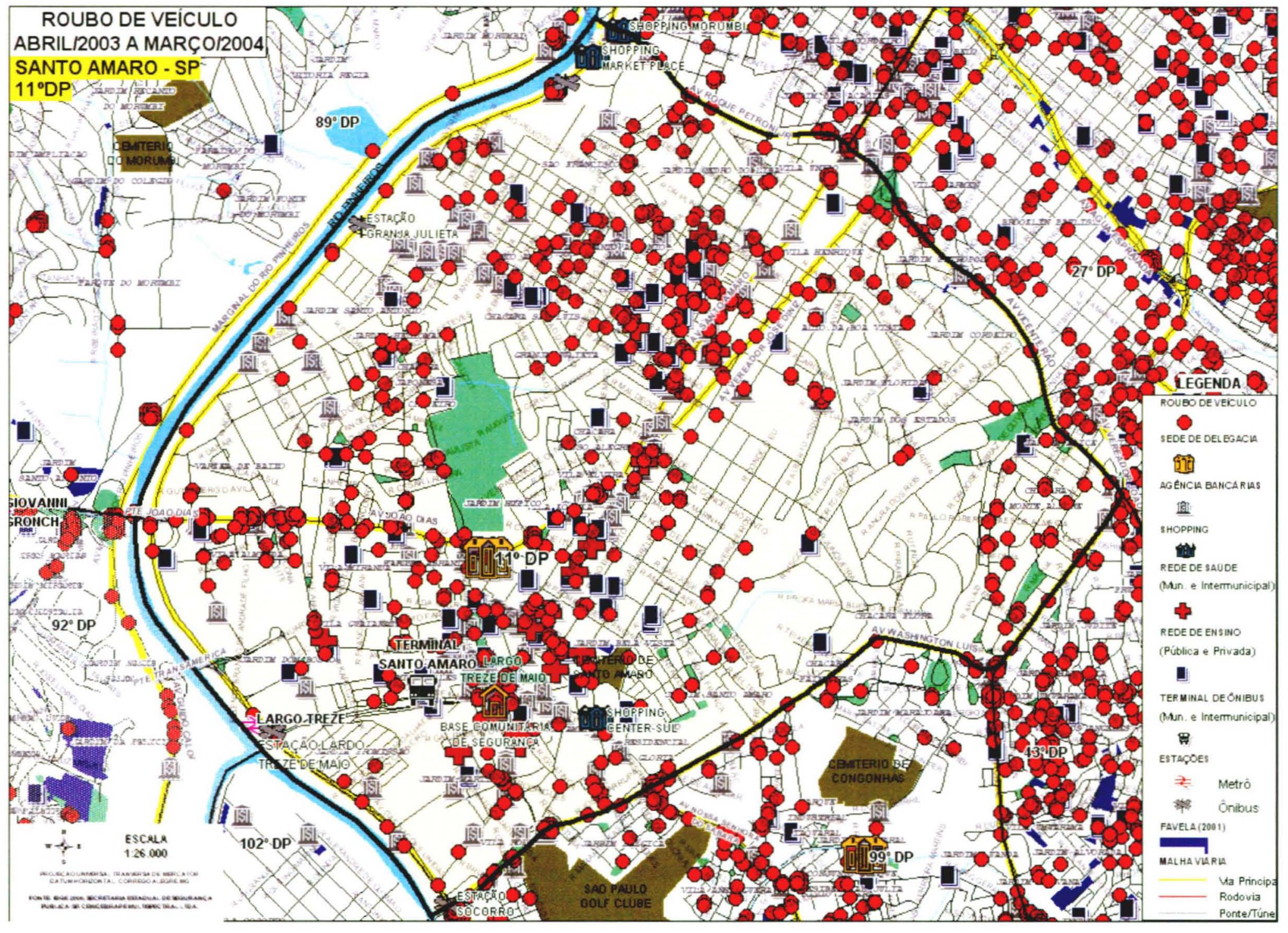

Figura 40 - Roubo de Veículo - Santo Amaro 


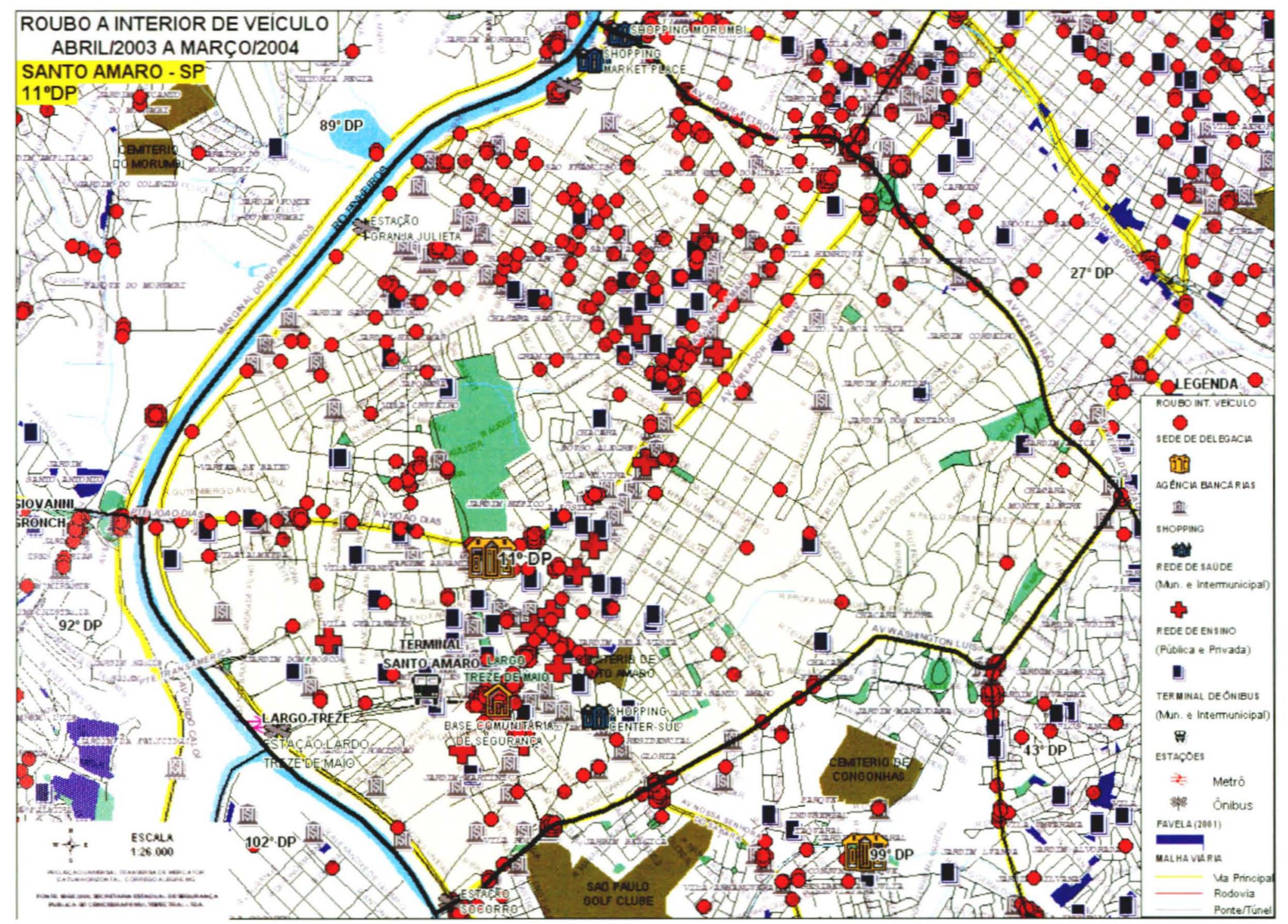

Figura 41 - Roubo a Interior de Veículo - Santo Amaro 


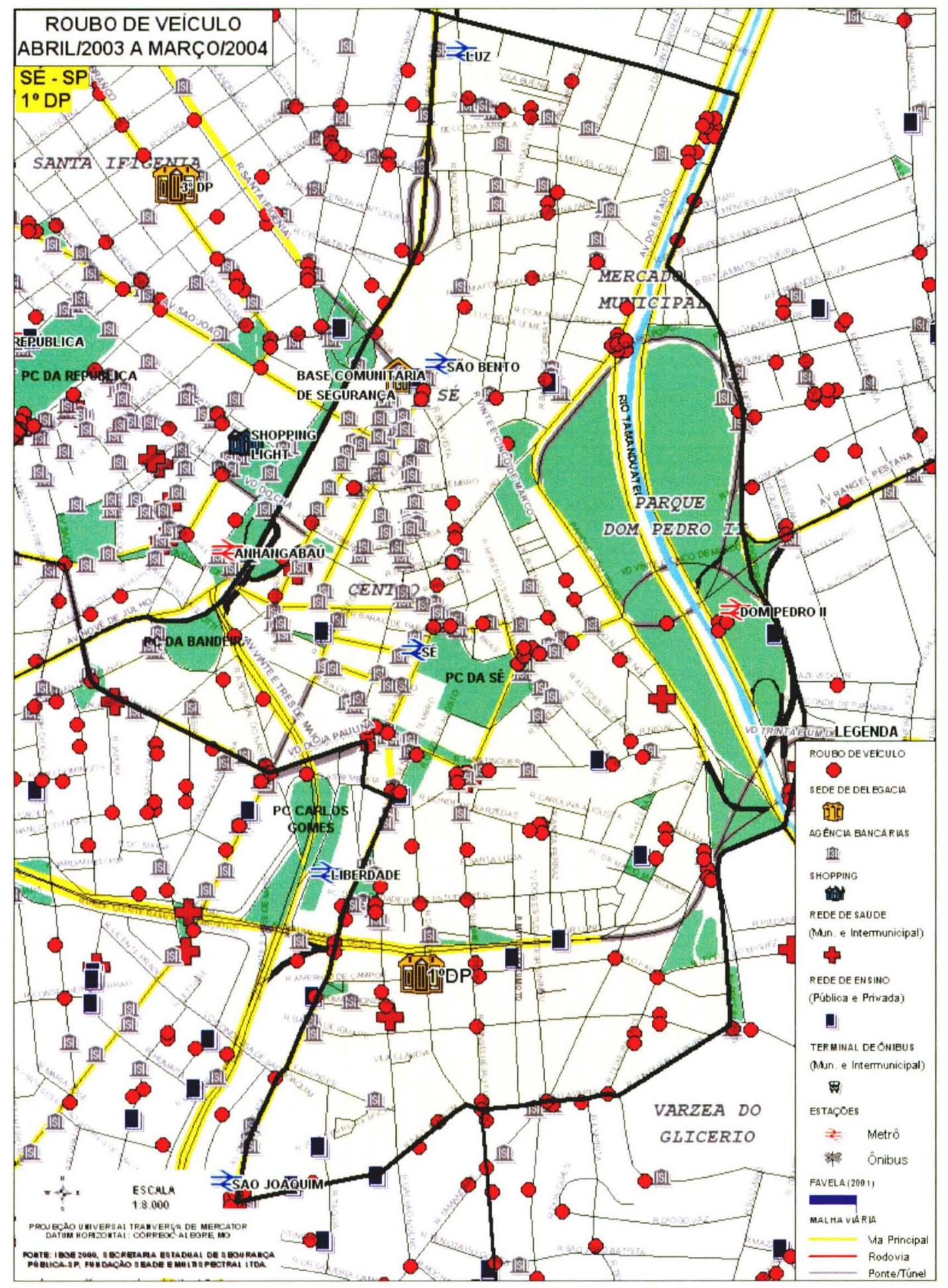

Figura 42 - Roubo de Veículo - Sé 


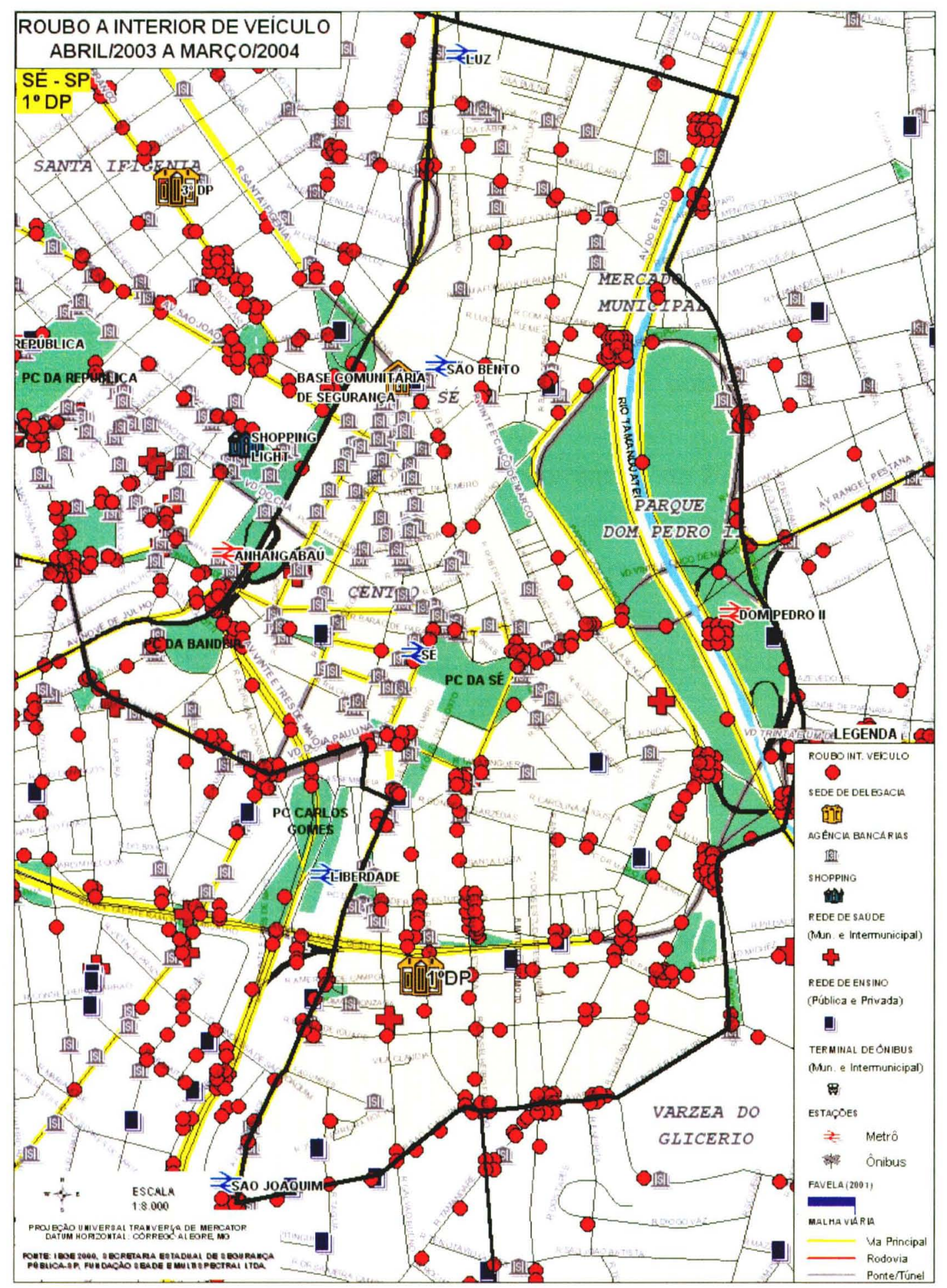

Figura 43 - Roubo a Interior de Veículo - Sé 
- Roubo de Veículo e Roubo a Interior de Veículo

O padrão de distribuição do Roubo a Interior de Veículos é semelhante nos Distritos Policiais de Santo Amaro e Sé. Em Santo Amaro, são bastante freqüentes, em números absolutos apresentam 396 registros e na Sé 378 registros. O Roubo de Veículo, no distrito de Santo Amaro já apresenta um número de ocorrências bem maior, 580 registros, concentrados ao longo das Avenidas Santo Amaro, João Dias, do Largo 13 e na Chácara Santo Antônio como um todo. Na Sé, os números são menores, 137 registros, disseminados nas áreas fora do distrito bancário no centro antigo, pois aí há restrições à entrada de automóveis.

No distrito de Capão Redondo, as ocorrências de Roubos de Veículos são bem mais freqüentes (647 registros) e distribuídos por toda a área. Já Roubo a Interior de Veículo são menos freqüentes (130 registros), mas concentrados ao longo da Estrada de Itapecerica. Nesta estrada, em algumas horas do dia, há congestionamento de trânsito, com ritmo lento e muitas paradas, o que favorece a atuação dos criminosos.

No distrito de Morumbi, os Roubos de Veículos aparecem, em primeiro lugar, com números bem mais expressivos (757 ocorrências), observados nas proximidades da Avenida Francisco Morato, no Caxingui e no Jardim Peri Peri; possivelmente pela maior facilidade de fuga pela avenida que desemboca em estrada. Já os Roubos a Interior de Veículo (517 registros) estão concentrados ao longo da Avenida Francisco Morato, mas também na Avenida Oscar Americano, na Avenida Tajurás e na Ponte do Morumbi, por onde trafegam automóveis de residentes de maior renda do bairro, os semáforos e o tráfego lento em algumas horas do dia, propiciam a ocorrência destes crimes.

Como já mencionado em outros pontos deste trabalho, não foi objetivo desta pesquisa trabalhar com a escala temporo-espacial, dadas limitações de tempo a que uma dissertação de mestrado está sujeita. No entanto, seria importante, numa próxima pesquisa, analisar dados temporais, tais como hora, 
dia e mês em que os crimes ocorreram, para que as análises sejam mais conclusivas.

Outro ponto importante a se ressaltar é que, possivelmente, há casos não notificados oficialmente, a causa pode estar na falta de credibilidade da policia e da justiça junto à população, pela morosidade dos processos, e pelo medo da vitima de sua identificação e dentre outras causas, conforme demonstra a Pesquisa de Vitimização na região metropolitana de São Paulo realizada pelo IFB (INSTITUTO FUTURO BRASIL 2003). 


\section{CONSIDERAÇÕES FINAIS E RECOMENDAÇÕES}

O presente trabalho, que teve como objetivo analisar a distribuição espacial das ocorrências criminais no município de São Paulo a partir da aplicação dos Sistemas de Informação Geográfica, durante o período de janeiro de 2001 a março de 2004, confirmou a hipótese de que não há homogeneidade/similaridade na distribuição dos diferentes tipos de crime na mancha urbana municipal. Tal diferenciação na incidência dos diferentes tipos de crime se deve, em parte, às diferenças nas motivações dos vários crimes, em parte às diferenças sócio-econômicas, demográficas e de fluxo de pessoas de trânsito e de transportes na cidade. Além da hipótese de que os SIG's são instrumentos úteis no entendimento e na gestão da violência urbana permitindo uma abordagem "multi-escalar" dos eventos selecionados.

Como conclui relatório da WHO, a violência é freqüentemente possível de se prever e prevenir e alguns fatores são fortemente indicativos de violência entre certos grupos populacionais, mesmo quando a causa direta é difícil de ser estabelecida. Dentre estes fatores, estão alto desemprego e deterioração de serviços públicos, além de fatores locais, específicos a cada lugar e momento. Segundo o mesmo relatório, todas sociedades experimentam violência, mas seu contexto - as circunstâncias em que ela ocorre, sua natureza e sua aceitação social - varia muito de um lugar a outro (WORLD HEALTH ORGANIZATION, 2002).

Além disso, a segregação ${ }^{45}$ residencial de grupos sócio-econômicos similares está muitas vezes associada a riscos à saúde diferenciados. Segundo Torres (2005), os estudos evidenciam que crescer em bairros com alta concentração de pobreza tem efeitos consideráveis na atividade criminal. $\mathrm{Na}$

\footnotetext{
${ }_{45}$ Segregação é o processo por meio do qual determinada população é forçada de modo involuntário a se agrupar em uma área determinada, em um gueto. É o processo de formação e manutenção do gueto (MARCUSE, P. Enclaves, Yes, Guettoes, No: segregation and the state. Apud Torres, H. Medindo a Segregação in MARQUES, E. ; TORRES, H. (orgs.) São Paulo, segregação, pobreza e desigualdades sociais. SENAC, S. Paulo, 2005. p. 83
} 
RMSP, o sentimento de mal-estar coletivo, a violência e a degradação urbana são talvez as manifestações mais aparentes da crescente segregação observada (TORRES, 2005, p. 99). A violência, entretanto, não é só um reflexo da segregação, ela é um elemento que retro-alimenta a formação de novos guetos. Formam-se, cada vez mais, os guetos das camadas populacionais de maior renda, os condomínios murados, guardados por seguranças privadas; ao lado das favelas e dos bairros auto-construídos que se adensam e estão sujeitos a outras formas/intensidades de violência.

O método geográfico e as técnicas de geoprocessamento, usados para investigar os padrões de semelhança e diferença na distribuição dos crimes, mostraram-se bastante eficientes para a manipulação dos mais de 3 milhões de dados de boletins de ocorrência. Os resultados obtidos, nas duas escalas ${ }^{46}$ geográficas abordadas, para cada tipo de crime, mostraram-se extremamente ricos tanto para a formulação de hipóteses causais, quanto para a identificação de pontos de maior risco de ocorrência, permitindo a formulação de programas / projetos mais adequados para o enfrentamento de cada tipo de crime.

Além disso, o geoprocessamento permitiu a sobreposição no mapa de uma série de fatores de risco e dos diferentes tipos de violência, sugerindo um grande potencial para parcerias entre grupos que atuam de forma diferenciada para os diversos tipos de crime, tanto na prevenção primária, quanto na secundária: governo municipal, membros da comunidade, planejadores urbanos, assistentes sociais, polícia, grupos defensores de direitos humanos, profissionais da saúde e pesquisadores, cada um em seu campo de atuação. Se a ação fragmentada destes diferentes atores sociais for superada, poder-seá ter ações mais compreensivas e efetivas.

Conforme o Ministério da Saúde, em nossa sociedade a violência tornouse problema de saúde pública pela sua magnitude e abrangência, com repercussões em diversas áreas. "O desenvolvimento de ações para o seu

\footnotetext{
${ }^{46}$ A escala foi entendida como um limite e um conteúdo, que estão sempre mudando, so sabora das variáveis dinåmicas que decidem sobre $o$ acontecer regional ou local.
} 
enfrentamento é um desafio para a política pública pela complexidade do problema e das soluções necessárias para seu manuseio. É fundamental a articulação das ações de diversos setores, governos e sociedade para buscar soluções" (MINISTÉRIO DA SAỦDE, 2004, p. 283).

O Ministério reconhece que tradicionalmente o setor saúde tem atuado para minimizar os problemas da morbimortalidade resultantes das agressões e que as ações de vigilância e prevenção são mais recentes, mas vêm se ampliando nos últimos anos.

O presente trabalho pode contribuir grandemente para essas ações de vigilância e prevenção. Além disso, pode ajudar a diminuir a pobreza e a instabilidade das famílias, acentuada pelos custos diretos $e$ indiretos associados à violência, que reduzem substancialmente a renda disponível para consumo das populações menos favorecidas.

Concluímos nosso trabalho, recomendando o comprometimento das entidades públicas e privadas paulistanas com a Resolução da $49^{\mathrm{a}}$ Assembléia Geral da Organização Mundial da Saúde (Resolution WHA49.25), denominada: Prevenir a violência: uma prioridade de Saúde Pública (WORLD HEALTH ORGANIZATION, 2002). Esta resolução declara que a violência é um dos principais problemas mundiais de Saúde Pública e conclama todos os países membros a avaliar o problema de violência em seus territórios e comunicar as informações e suas formas de abordagem ao problema à Organização Mundial da Saúde. Dentre as recomendações incluídas no documento, está a promoção da pesquisa sobre violência como uma prioridade de pesquisa da Saúde Pública.

Recomendamos, portanto, o desenvolvimento de novas pesquisas: a) que abordem a perspectiva temporal dos crimes analisados neste trabalho de modo a permitir o aprofundamento das análises; b) que ampliem a analise da distribuição espacial e temporal dos crimes a todos os distritos policiais do municipio; c) que investiguem as características pessoais dos envolvidos nas ocorrências de naturezas criminais. 


\section{REFERÊNCIAS}

Alencar F, Ramalho LC, Ribeiro MVT. História da sociedade brasileira. $3^{a}$. ed. Rio de Janeiro: Ao Livro Técnico; 1985.

Andrade MEB. Geografia Médica: origem e evolução. In: Barradas R, Briceño R, coordenadores. Doenças infecciosas. Abordagens sociais, culturais, e comportamentais. Rio de Janeiro: FIOCRUZ; 2000.

Aronoff S. Geographical Information Systems: a manegement perspective. Ottawa: WDI Publications; 1989.

Barcelos C, Bastos F. Geoprocessamento, ambiente e saúde: uma união possivel? In: Cadernos de Saúde Pública. 1996; 12 (3): 389-397.

Barrett F A. Disease and Geography. The History of an idea. Geographical Monographs. 2000; n. 23.

Borlina M P. Motalidade por Agressão : um exercício com as informações de óbito georeferenciadas no Município de São Paulo - Trabalho da Disciplina Geografia da Saúde e da Doença - Faculdade de Saúde Pública USP - São Paulo, 2003. 
Burrough P, Mc Donnell R. Principles of Geographical Information Systems. Oxford: Oxford University Press; 1998.

Calvino I. Palomar. São Paulo: Companhia das Letras; 1994.

Câmara G. Modelos, linguagens e arquiteturas para banco de dados geográficos. São José dos Campos; 1995. [Tese de doutorado - Instituto Nacional de Pesquisa Espaciais (INPE)].

Câmara G. et. al. Geoprocessamento: teoria e aplicações [livro online] 2000; 1.[50 screens]. Disponível em<URL: http://www.dpi.inpe.br/livro> [2001 mai 12].

Camargo A B M, Ortiz L P, Fonseca L A M. Evolução da Mortalidade por Acidentes e Violência em Áreas Metropolitanas. In: Monteiro C A, coordenador. Velhos e Novos Males de Saúde no Brasil. São Paulo: Hucitec e Nupens; 2000.

Campos M A M R, Shor N Anjos R M P, Laurenti J C, Santos D V e Peres F. Violência sexual: integração saúde e segurança pública no atendimento imediato à vitima. Saúde e Sociedade. 2005; 14 (1).

Cantão CM. A Terra no espaço. In: Fundação IBGE. Curso de Informações Geográficas. Rio de Janeiro: Divisão Cultural; 1967. p. 17-32. 
Carlos AFA. A (re)produção do espaço urbano. São Paulo: EDUSP; 1994.

Carrera-Fernandez J, Pereira R. A economia do crime: uma abordagema apartir da Região Policial da Grande São Paulo. In: Economia. Rio de Janeiro: ANPEC (Associação nacional de centros de Pós-Graduação em Economia); 2002; 3.

Carvalho MS. Aplicação de métodos de análise espacial na caracterização de áreas de risco à saúde. Rio de Janeiro; 1997. [Tese de Doutorado Universidade Federal do Rio de Janeiro].

Carvalho MS, Pina MF, Santos SM. Conceitos básicos de Sistemas de Informação Geográfica e cartografia aplicados à saúde. Brasilia (DF): Organização Panamericana da Saúde/ Ministério da Saúde; 2000.

Cintra J P. Apostila de Sistema de Projeção UTM. Laboratório de Topografia e Geodésia, Departamento de Engenharia de Transportes da Escola Politécnica da Universidade de São Paulo. São Paulo; 1997.

Coimbra JAA. O outro lado do Meio Ambiente. São Paulo: CETESB; 1985.

CONSELHO REGIONAL DE MEDICINA. Associação Paulista de Medicina. A epidemia da violência. São Paulo. 1998.

Corrêa RL. Região e Organização Espacial. São Paulo: Ática; 1986. 
Costa AJL. Mensuração do grau de incapacitação funcional através de um modelo baseado na Lógica Fuzzy. São Paulo; 2001. [Tese de Doutorado Faculdade de Saúde Pública da USP].

Costa GF. Geoprocessamento: uso e aplicação na Saúde Pública e na Saúde Ambiental. In: Ribeiro $H$, coordenador. Olhares Geográficos: meio ambiente e saúde. São Paulo: SENAC; 2005.

Cowen DJ. GIS versus CAD versus DBMS: what are de differences. Photogrammetric Engineering and Remote Sensing, 1988; 54.

Dina C, Ribeiro AM. O conceito de espaço em epidemiologia: uma interpretação histórica e epistemológica. Cadernos de Saúde Pública. Rio de Janeiro; 2000.

Domingues E, Silva G. Saúde e meio ambiente: a proposta do Projeto de Indicadores de Sistema de Informações no IBGE. Rio de Janeiro: Fiocruz; 2000.

Ferreira C. Sistema de Informação Geoambiental: metodologia e concepção aplicadas. Rio de Janeiro; 1992. [Dissertação de Mestrado - IME]. 
Ferreira C, Castineira L. O rápido aumento da mortalidade dos jovens adultos em São Paulo : uma trágica tendência. São Paulo em Perspectiva. Fundação Seade. 1996, v. $10(2)$, p. $35-41$.

Ferreira SMG, Azevedo PCV. Sistemas de informação para tomada de decisões em saúde - SINTOMAS: Sistemas de Informação Geográfico para Sistemas Locais de Saúde. In. Mendes EV, org. A organização da saúde no nível local. São Paulo: Hucitec; 1998.p.133-53.

Foratini OP. Ecologia, epidemiologia e sociedade. São Paulo: EDUSP;1992.

FUNASA. Instrumentos básicos para a vigilância ambiental em saúde. [Curso básico de vigilância ambiental em saúde; 2001 mar; Rio de Janeiro, $(B R)]$.

Fundação IBGE. Censo demográfico: resultados do Universo - São Paulo.

Rio de Janeiro; 2002. v.1; (11 Recenseamento Geral do Brasil).

Síntese de indicadores sociais 1999. Rio de Janeiro; 2000. (Estudos e Pesquisas, Informação Demográfica e Socieconômica, 4).

Fundação Seade. Sistema de Estatísticas Vitais. Governo do Estado de São Paulo. São Paulo; 2003. 
Galvão E F, Andrade S M. Violência contra a mulher: análise de casos atendidos em serviço de atenção à mulher em Municipio do Sul do Brasil. Saúde e Sociedade. São Paulo; 2004 Vol. 13/2, p. 89-99,.

George P. Os Métodos da Geografia. Rio de Janeiro: DIFEL; 1978.

Godoy MA. Indicadores de sustentabilidade ambiental para análise de transposições hídricas. São Paulo; 2000. [Dissertação de Mestrado Faculdade de Saúde Pública da USP].

Gonçalves CWP. Possibilidades e limites da ciência e da técnica diante da questão ambiental. In: Seminários Universidade e Meio Ambiente; 1989; Brasilia, (DF). Brasilia: IBAMA;1989.

Goodchild M. Geographic data modeling. Computer and Geosciences. 1992 18, p.401-408.

Grossi K. Violência contra a Mulher: implicações para os profissionais de saúde. In: Lopes M J M, Meyer D E, Waldow V R (orgs.). Gênero e Saúde. Porto Alegre: Artes Médicas; 1996, p. 133-149.

Gottdiener M. A produção social do espaço urbano. São Paulo, Edusp; 1993. 
Guerra C. Violência e poder nas relações de gênero - as cenas. Caderno Espaço Feminino. Uberlândia; 1997. v. 4, p. 5-27..

Gouveia N. Saúde e meio ambiente nas cidades: os desafios da saúde ambiental. In: Revista Saúde e Sociedade 1999; 8(1): 49-61.

INSTITUTO FUTURO BRASIL (IFB). Pesquisa de vitimização na região metropolitana de São Paulo. São Paulo: IFB; 2003.

INSTITUTO UNIEMP. Projeto para a organização de um Centro de Análise Criminal na Secretaria de Segurança Pública de São Paulo. São Paulo: UNIEMP; 2003.

INPE (Instituto Nacional de Pesquisas Espaciais). Fundamentos de geoprocessamento. [Tutorial]. São José dos Campos (SP): INPE; 2000.

SPRING. Manual do usuário. Versão 3.6. São José dos Campos: INPE; 2001.

Jorge M H P, Gotlieb S L D. As Condiçōes de Saúde no Brasil. Rio de Janeiro: Ed. Fiocruz; 2000. 
Koogan L, seleções. Dicionário enciclopédico. Rio de Janeiro: Larousse do Brasil; 1979. 2 v.

Krafta R, Moraes Neto V. Segregação dinâmica: modelagem e mensuração. In: Revista Brasileira de estudos urbanos e regionais. 1999; 1.

Lacaz CS, et al. Introdução à geografia médica do Brasil. São Paulo: Edgard Blucher, 1972.

Lago L. Estruturação urbana e mobilidade espacial: uma análise das desigualdades sócio-espaciais na metrópole do Rio de Janeiro. São Paulo; 1998. [Tese de doutorado - Faculdade de Arquitetura e Urbanismo da USP].

Langenbuch, JR. Assentamento Industrial na Grande São Paulo. S.d. (Mimeo).

A estruturação da Grande São Paulo - estudo de geografia urbana. Rio de Janeiro: IBGE - Departamento de Documentação Gráfica; 1971.

Laurell AC. A saúde-doença como processo social. In: Medicina social: aspectos históricos e teóricos. 1983; 3.

Laurenti R, et al. Estatística de saúde. São Paulo: EPU/EDUSP; 1985. 
Lefebvre H. Le Detroit a la Ville. Paris: Editions Anthropos; 1968.

O direito à cidade. São Paulo: Moraes; 1991.

Maguire D, Goodchild M, Rhind D. Geographical information systems: principles and applications. New York: John Wiley and Sons; 1991.

Marques E; Torres H (org.) São Paulo segregação, pobreza e desigualdades sociais. São Paulo: SENAC; 2005.

Martin D. Geographic Information Systems: socioeconomic applications. $2^{\text {* }}$ ed. London: Routledge; 1995.

Martins ER. Da geografia à ciência geográfica e o discursos lógico. São Paulo; 1996. [Tese de Doutorado - Faculdade de Filosofia Letras e Ciências Humanas da USP].

Meade F, et al. Medical Geography. Nova York: The Guilford Press, 1988.

Mendonça F. Clima e Criminalidade: ensaio analítico da correlação entre a temperatura do ar e a incidência da criminalidade urbana. Curtibia: Ed. UFPR; 2001. 
Mc Dowell I, Newel C. Measuring health: a guide to rating scales and questionnaires. Oxford: Oxford University Press; 1997.

MC Glashan ND. Medical Geography: an Introduction. In Meade MM (ed.) Conceptual and Methodological Issues in Medical Geography. Studies in Geography 15. University of North Carolina. Chapel Hill; 1980.

Medeiros JS de. Banco de dados geográficos e redes neurais artificiais: tecnologias de apoio à gestão do território. São Paulo; 1999. [Tese de Doutorado - Faculdade de Filosofia Letras e Ciências Humanas da USP].

Minayo MCS. A violência social sob a perspectiva da Saúde Pública. Cadernos de Saúde Pública. Rio de Janeiro, 1994; 10: p.7-18.

Ministério da Saúde. Rede Interagencial de Informações para a Saúde RIPSA. Conceitos básicos de Sistemas de Informação Geográfica e cartografia aplicados à saúde. Brasília (DF); 2000.

Ministério da Saúde. Saúde Brasil 2004 : uma análise da situação de saúde. Brasilia: Secretaria de Vigilância em Saúde; 2004.

Monteiro CA, organizador. Velhos e novos males da saúde no Brasil: a evolução do pais e suas doenças. São Paulo: Hucitec/Nupens/USP; 1995. 
Moraes ACR. Pequena História Crítica. São Paulo: HUCITEC; 1988.

Meio ambiente e ciências humanas. São Paulo: Hucitec; 1997.

Moran E. Adaptabilidade Humana. São Paulo. Edusp, 1994.

Moreira R. Espaço, Corpo do Tempo. São Paulo; 1994. [Tese de Doutorado Faculdade de Filosofia, Letras e Ciências Humanas da USP].

Novo EML de M. Sensoriamento remoto: principios e aplicações. $2^{a}$ ed. São Paulo: Edgard Blucher;1998.

Paraguassu-Chaves CA. Geografia Médica ou da Saúde - espaço e doença na Amazônia Ocidental. Porto-Velho: EDUFRO, 2001.

Paredes EA. Sistema de informação geográfica (geoprocessamento): princípios e aplicações. São Paulo: Érica; 1994.

Pedroso M M. Desenvolvimento Humano no Município de São Paulo (2000) Uma cartografia socioeconômica como contribuição ao planejamento de políticas públicas. São Paulo, 2003 [Dissertação de Mestrado - Programa de Economia Política. Pontifícia Universidade Católica de São Paulo] 
Pereira JCR. Análise de dados qualitativos: estratégias metodológicas para as ciências da saúde, humanas e sociais. $3^{a}$. ed. São Paulo: EDUSP; 2001.

Pessoa SB. Ensaios médicos-sociais. Rio de Janeiro: Koogan; 1960.

Peuquet DJ. A conceptual framework and comparison os spatial data model. New York: Prentice-Hall; 1990.

PMSP - PREFEITURA DO MUNICÍPIO DE SÃO PAULO. Óbitos por causas $\begin{array}{llll}\text { externas. } & 2000 . & \text { Disponivel }\end{array}$ <http:www.prefeitura.sp.gov.br/secretarias/saúde/DATA-tabnet/SIM/óbito.def. > [2004 Jun 5]

PML - PREFEITURA MUNICIPAL DE LONDRINA. Secretaria Especial da Mulher. Violência contra a mulher: informação e orientação. Londrina, 1998.

Ribeiro H. A crise ambiental e o ressurgimento da geografia médica. São Paulo: Educ: 1996. Coleção Pré-Print.

Poluição do ar e doenças respiratórias em crianças da Grande São Paulo: um estudo de geografia médica. São Paulo, 1988. [Tese de Doutorado - Faculdade de Filosofia, Letras e Ciências Humanas da USP]. 
Análise espacial e saúde pública. In: Dowbor L, Kilsztajn S. Economia social no Brasil. São Paulo: SENAC, 2001.

Geografia da Saúde e da Doença aplicada à poluição do ar em São Paulo. In: Ribeiro H, coordenador. Olhares Geográficos: meio ambiente e saúde. São Paulo: SENAC; 2005.

Rojas L I, Barcellos C. Geografia y salud em America Latina: evolución y tendencias. Revista Cubana de Salud Publica. 2003; 29 (4): 330-343.

Rocha AA. Ciências do ambiente, saneamento e saúde pública. São Paulo; 1995.

Rodrigues M. Introdução ao geoprocessamento. [Apresentado ao Simpósio Brasileiro de Geoprocessamento; 1990 maio; Escola Politécnica - USP, São Paulo (SP)].

Rosen G. Uma história da Saúde Pública. São Paulo: Hucitec, Editorada Universidade Estadual Paulista; Rio de Janeiro: Associação Brasileira de PósGraduação em Saúde Coletiva; 1994.

Saffioti H, Almeida S S. Violência de gênero: poder e impotência. Rio de Janeiro: Revinter; 1995. 
Santos M. A Natureza do Espaço. São Paulo: Hucitec;1999.

Silva AC da. O Espaço Fora do Lugar. São Paulo: Hucitec; 1978.

Silva DJ, Pompeu CA. Enfoques Epistemológico, politico e filosófico na leitura da questão ambiental. In: Seminários Universidade e Meio Ambiente. 1989; Brasília, (DF). Brasília: IBAMA;1989.

SÃO PAULO (Estado). Lei n. 10.920/01. Obriga as Delegacias de Polícia a informar às vítimas de crimes contra a liberdade sexual o direito de tratamento preventivo contra a contaminação pelo vírus HIV. Diário Oficial do Estado de São Paulo. São Paulo, vol. 111, n. 194, 12 de out. 2001. Seção I.

Silva LO. A organização do espaço construído e qualidade ambiental: o caso da cidade de São Paulo. In: Revista Polis. 1991; 3: 29-35.

Singer P. Economia política da urbanização. São Paulo: Contexto; 1998.

Soja E. Geografias pós-modernas: a reafirmação do espaço na teoria social crítica. Rio de Janeiro: Jorge Zahar; 1993.

Sorre M. Les fondements biologiques de la géographie humaine, essai d'une écologie l'homme. Paris: Librairie Armand Colin; 1955. 
Souza ML. Mudar a cidade: uma introdução crítica ao planejamento e à gestão urbanos. São Paulo: Bertrand Brasil; 2002.

Teixeira AL de A, Moretti E, Christofoletti A. Introdução aos Sistemas de Informação Geográfica. Rio Claro: Ed. do autor; 1992.

Universidade de São Paulo. Faculdade de Saúde Pública. Biblioteca/CIR. Guia de Apresentação de Teses. São Paulo: A Biblioteca; 2001.

Urteaga JLG . Miseria, miasamas y microbios. Las topografías médicas y el estudio del medio ambiente en el siglo XIX. In: El Higienismo em España em el siglo XIX el paradigma de las Topografias médicas. Barcelona; 1980. [Tesis de Licenciatura - Departamento de Geografia de la Universidad de Barcelona].

Vaughan JP, Morrow RH. Epidemiologia para municípios: manual para gerenciamento dos distritos sanitários. $3^{\text {a }}$. ed. São Paulo: Hucitec; 2002.

WHO - World Health Organization. World report on violence and health. EBook. $\quad$ Geneva; 2002 Disponivel em: http://www.who.int/violence_injury_prevention/violence/world_report/wrvheng/en /print/html. [2005 oct 19] 
Centre for Health Development. Proceedings of a WKC Consultative Meeting on Health Planning and Delivery at City Level. 25-27 November, 2003. Kobe, Japan; 2004. 


\section{ANEXO}

\section{A1 - Mapa da Região Metropolitana de São Paulo.}

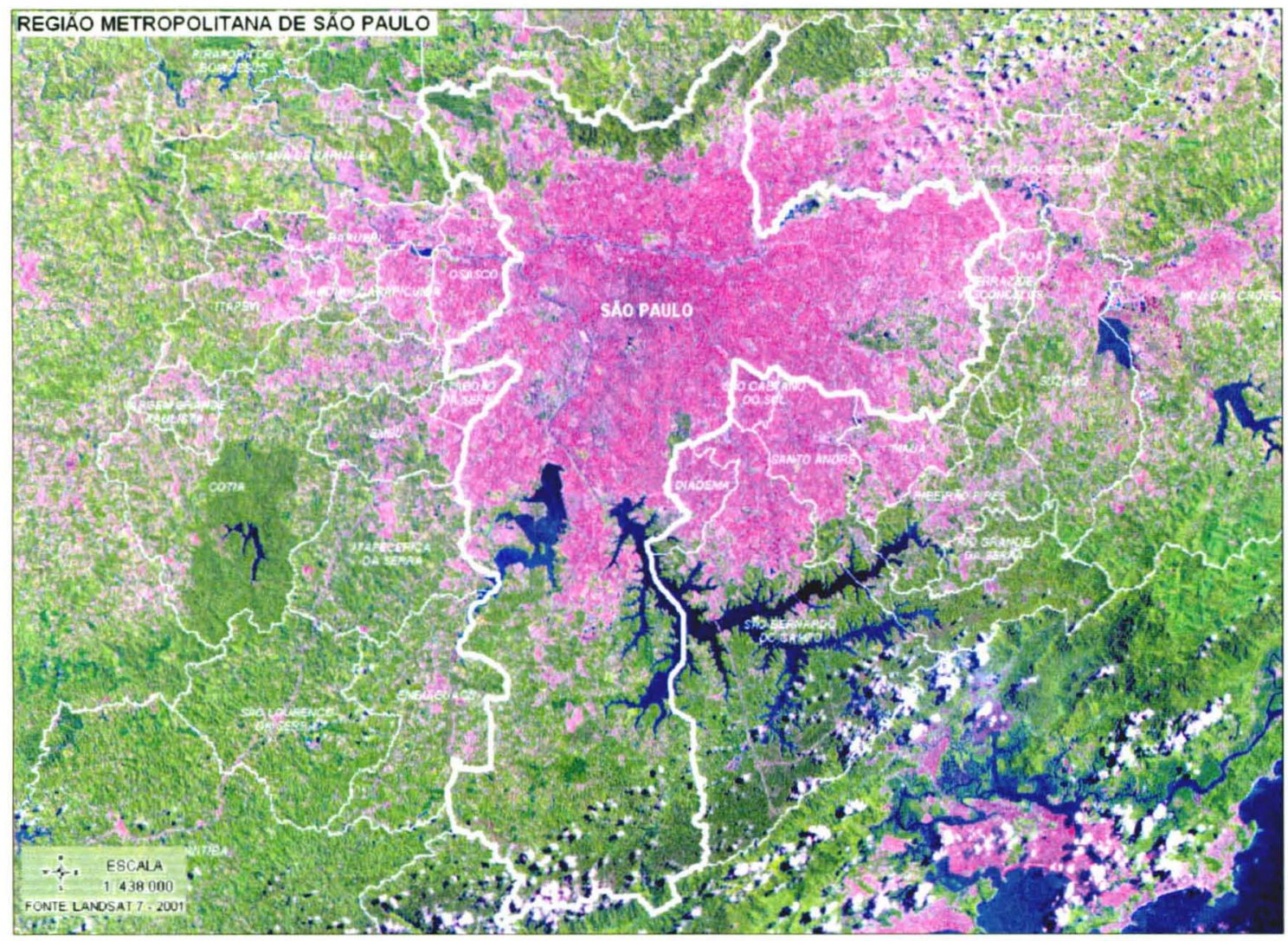

A2 - Tabela de Crimes por Natureza.

CRIMES POR NATUREZA (01/2001 A 03/2004)

\section{Natureza}

ABALROAMENTO

ABANDONO DE FUNCAO

ABANDONO DE INCAPAZ

ABANDONO DE RECÉM-NASCIDO

ABANDONO INTELECTUAL

ABANDONO MATERIAL

ABORTO

ABUSO DE AUTORID.- LEI 4898/65

ABUSO DE INCAPAZES

ABUSO DE PODER

ABUSO NA PRATICA DE AVIACAO

ABUSO PODER ECONOM.LEI 4137/62

AÇÃO DE ALIMENTOS- L 5478/68

ACIDENTE DE TRABALHO

AÇÚCAR E ÁLCOOL- DL 16/66

ADULTERACAO/ALIMENTO OU

$\begin{array}{cc}\text { Freqüência } & \text { Porcentagem } \\ 3008 & , 1 \\ 30 & , 0 \\ 1036 & , 0 \\ 150 & , 0 \\ 153 & , 0 \\ 1219 & , 0 \\ 605 & , 0 \\ 625 & , 0 \\ 522 & , 0 \\ 187 & , 0 \\ 78 & , 0 \\ 15 & , 0 \\ 12 & , 0 \\ 840 & , 0 \\ 8 & , 0 \\ 139 & , 0\end{array}$


REMED.

ADULTERIO

ADVOCACIA ADMINISTRATIVA

AGROTÓX./COMPONENTES-L.7802/89

ALICIAMENTO DE TRABALHADORES

ALTERACAO DE LIMITE

ALTERACAO DE LOCAL

AMEACA

ANUNCIO DE MEIO ABORTIVO

APOLOGIA DOS CRIMES

APREENSAO DE OBJETO

APROPRIACAO INDEBITA

ARREBATAMENTO DE PRESO

ARREMESSO DE PROJETIL

ARREMESSO/COLOCACAO PERIGOSA

ASSEDIO SEXUAL

ASSOCIACAO PARA O TRAFICO

ASSOCIACAO SECRETA

ATENTADO C/ LIBERDADE TRABALHO

ATENTADO C/MEIO DE TRANSPORTE

ATENTADO C/ SERVICO PUBLICO

ATENTADO C/LIBERDADE ASSOCIAC.

ATENTADO VIOLENTO AO PUDOR

ATENTADO/PUDOR MEDIANTE

FRAUDE

ATESTADO MEDICO FALSO

ATIV. C/INFRACAO DECISAO ADM

ATO INFRACIONAL

ATO OBSCENO

ATROPELAMENTO

AUTO-ACUSAÇÃO FALSA

AUTO LESAO

AVERIGUACAO

BIGAMIA

C/CONSUMIDOR - LEI 8078/90

C/CRIANCA/ADOLESC. LEI 8069/90

C/LEI DE ESTRANG. LEI 6815/80

C/LIBERDADE PENSAM.-L. 5250/67

C/PROPRIED.INTELEC.LEI 7646/87

C/SEGUR.NACIONAL - LEI 7170/83

C/SERV. POSTAL - LEI 6538/78

C/SIMBOLOS NACION. LEI 5700/71

C/SIST.FINANCEIRO-LEI 7492/86

CALUNIA

CAPOTAMENTO

CAPTURA DE PRESO

CAPTURA DE PROCURADO

CARCERE PRIVADO

CASA DE PROSTITUICAO

CETÁCEOS- L 7643/87

CHARLATANISMO

CHEQUE SEM FUNDO

CHOQUE

COACAO NO PROCESSO

CODIDO DE PESCA-DEC LEI 221/67

CODIGO DE CACA - LEI 5197/67

CODIGO TRANSITO BRAS.-L.9503/97

COLISAO

COMERCIO ILEGAL ANTIGUIDADES

COMUNICACAO DE OBITO

\begin{tabular}{|c|c|}
\hline \multirow{3}{*}{\multicolumn{2}{|c|}{$\begin{array}{c}288 \\
12\end{array}$}} \\
\hline & \\
\hline & \\
\hline 24 & \\
\hline 131 & \\
\hline 16 & \\
\hline 204090 & \\
\hline 8 & \\
\hline 54 & \\
\hline 49882 & \\
\hline 15720 & \\
\hline 19 & \\
\hline 151 & \\
\hline 475 & \\
\hline 77 & \\
\hline 480 & \\
\hline 5 & \\
\hline 276 & \\
\hline 54 & \\
\hline 124 & \\
\hline 4 & \\
\hline 7960 & \\
\hline 115 & \\
\hline 138 & \\
\hline 2 & \\
\hline 70273 & \\
\hline 2328 & \\
\hline 1422 & \\
\hline 11 & \\
\hline 3757 & \\
\hline 69058 & \\
\hline 6 & \\
\hline 4952 & \\
\hline 653 & \\
\hline 7 & \\
\hline 26 & \\
\hline 17 & \\
\hline 18 & \\
\hline 47 & \\
\hline 1 & \\
\hline 37 & \\
\hline 10349 & \\
\hline 278 & \\
\hline 7222 & \\
\hline 24908 & \\
\hline 578 & \\
\hline 184 & \\
\hline 1 & \\
\hline 15 & \\
\hline 295 & \\
\hline 3338 & \\
\hline 1097 & \\
\hline 15 & \\
\hline 169 & \\
\hline 957 & \\
\hline 12853 & \\
\hline 1 & \\
\hline 554 & \\
\hline
\end{tabular}


CONCORRENCIA DESLEAL

CONCUSSAO

CONDESCENDENCIA CRIMINOSA

CONSTRANGIMENTO

CONSTRANGIMENTO ILEGAL

CONTRA NACIONALIZ. DO TRABALHO

CONTRABANDO

CONTRAV.EM LOCAÇĀO-LEI 6649/79

CONTRAVENCAO PENAL -

DESABAMENTO

CORRUPCAO ATIVA

CORRUPCAO DE MENOR/LEI 2252/54

CORRUPCAO DE MENORES

CORRUPCAO PASSIVA

CRIME C/DIR.GREVE-LEI 4330/64

CRIME C/ECON.POPULAR-L.1521/51

CRIME C/INDIO - LEI 6001/63

CRIME DE RESPONS.- DL 201/67

CRIME DE RESPONS.-LEI 10079/50

CRIME ELEITORAL - LEI 4737/65

CRIME FALIMENTAR - DL 7661/45

CRIME FLORESTAL - LEI 4771/65

CRIME/PROPRIED.IND.-DL 7903/45

CRIMES CONTRA CPI

CRUELDADE CONTRA ANIMAIS

CURANDEIRISMO

CUSTODIA INDEV.DOENTES MENTAIS

DANO

DANOS NUCLEARES - LEI 6453/77

DAR PARTO ALHEIO COMO PROPRIO

DENUNCIACAO CALUNIOSA

DESABAMENTO

DESACATO

DESAPARECIMENTO DE PESSOAS

DESENTENDIMENTO

DESOBEDIENCIA

DESOBEDIÊNCIA AO MP- L 7347/85

DESVIO DE CARGA

DIFAMACAO

DIRECAO PERIGOSA

DIRECAO SEM HABILITACAO

DIRIGIR SEM PERMISSAO/HABIL.

DISPARO DE ARMA DE FOGO

DIVULGACAO DE SEGREDO

DUPLICATA SIMULADA

EMBRIAGUEZ

EMBRIAGUEZ AO VOLANTE

EMISSAO DE FUMACA, VAPOR OU GAS

EMISSAO ILEGAL DE TITULO

EMPREGO DE SUBSTANCIA PROIBIDA

ENCONTRO DE CADAVER

ENCONTRO DE PESSOA

ENGAVETAMENTO

ENTR. OBJETO LOCAL./APREEND.

ENTR. VEICULO LOCAL./APREEND.

ENTREGAFILHO A PESSOA INIDON.

ENVENENAMENTO DE AGUA

POTAVEL

EPIDEMIA

ESBULHO POSSESSORIO 


\begin{tabular}{|c|c|c|}
\hline \multirow{3}{*}{$\begin{array}{l}\text { ESCRITO OBSCENO } \\
\text { ESTATUTO DO DESARMAMENTO-LEI } \\
10826 / 2003 \\
\text { ESTATUTO DO IDOSO-LEI 10741/2003 } \\
\text { ESTELIONATO }\end{array}$} & $\begin{array}{c}27 \\
1766\end{array}$ & $\begin{array}{l}, 0 \\
, 0\end{array}$ \\
\hline & 68 &, 0 \\
\hline & 130112 & 3,0 \\
\hline ESTUPRO & 7258 & ,2 \\
\hline ESTUPRO TENTADO & 1795 &, 0 \\
\hline EXCESSO DE EXACAO & 5 &, 0 \\
\hline EXERC.ARBITRAR.PROPRIAS RAZOES & 7935 & , 2 \\
\hline EXERCICIO ILEGAL DA MEDICINA & 73 &, 0 \\
\hline EXERCICIO ILEGAL DA PROFISSAO & 1057 &, 0 \\
\hline EXPLORACAO CREDULIDADE & 10 &, 0 \\
\hline $\begin{array}{l}\text { PUBLICA } \\
\text { EXPLORACAO DE PRESTIGIO }\end{array}$ & 8 & 0 \\
\hline EXPLOSAO & 359 & 0 \\
\hline EXTORSAO & 3139 &, 1 \\
\hline EXTORSAO MEDIANTE SEQUESTRO & 690 &, 0 \\
\hline EXTRAVIO DE LIVRO/DOCUMENTO & 26 &, 0 \\
\hline EXTRAVIO DE PLACAS & 8441 & ,2 \\
\hline FABRICACAO DE ENTORPECENTE & 15 &, 0 \\
\hline FABRICO/COMERCIO & 42 &, 0 \\
\hline ARMAS/MUNICAO & & \\
\hline FACILITACAO DE CONTRABANDO & 4 &, 0 \\
\hline FALSA COMUNICACAO DE CRIME & 995 &, 0 \\
\hline FALSA IDENTIDADE & 1286 & 0 \\
\hline FALSA INDICACAO DE PROCEDENCIA & 3 &, 0 \\
\hline FALSA INDICACAO DE RECIPIENTE & 1 &, 0 \\
\hline FALSIDADE IDEOLOGICA & 2484 &, 1 \\
\hline FALSIFICACAO / PAPEIS PUBLICOS & 351 &, 0 \\
\hline FALSIFICACAO CERTIDAO/ATESTADO & 158 &, 0 \\
\hline FALSIFICACAO DE SELO & 52 & 0 \\
\hline FALSIFICACAO DOCUMENTO PARTIC. & 1667 & 0 \\
\hline FALSIFICACAO DOCUMENTO PUBLICO & 2386 &, 1 \\
\hline FALSO ALARME & 47 & 0 \\
\hline FALSO RECONHECIMENTO DE FIRMA & 50 & 0 \\
\hline FALSO TESTEMUNHO & 84 &, 0 \\
\hline FALTA DE HABILITACAO & 15126 & ,3 \\
\hline FALTA HABILITACAO P/AERONAVE & 5 & 0 \\
\hline FAVORECIMENTO DA PROSTITUICAO & 70 &, 0 \\
\hline FAVORECIMENTO PESSOAL & 137 & 0 \\
\hline FAVORECIMENTO REAL & 68 & 0 \\
\hline FRAUDE A EXECUCAO & 10 &, 0 \\
\hline FRAUDE PROCESSUAL & 34 & 0 \\
\hline FRAUDES & 1627 & 0 \\
\hline FUGA COM VIOLENCIA & 198 &, 0 \\
\hline FUGA CONSUMADA & 1785 & .0 \\
\hline FUGA DE LOCAL DO ACIDENTE & 1844 & 0 \\
\hline FUGA TENTADA & 1500 & 0 \\
\hline FURTO-ESTAB.OUTROS & 3142 &, 1 \\
\hline FURTO-INTERIOR ESTAB & 5783 & ,1 \\
\hline FURTO-INTERIOR TRANSP.COLET. & 5615 &, 1 \\
\hline FURTO - BIP/PAGER/CELULAR & 23583 &, 5 \\
\hline FURTO - CARGA & 3261 &, 1 \\
\hline FURTO - DOCUMENTOS & 130028 & 3,0 \\
\hline $\begin{array}{l}\text { FURTO - ESTABELECIMENTO } \\
\text { BANCARIO }\end{array}$ & 7761 & ,2 \\
\hline FURTO - ESTABELECIMENTO & 60636 &, 4 \\
\hline COMERCIAL & & \\
\hline FURTO - ESTABELECIMENTO ENSINO & 9570 & ,2 \\
\hline FURTO - INTERIOR DE VEICULC & 72797 & 1,7 \\
\hline
\end{tabular}




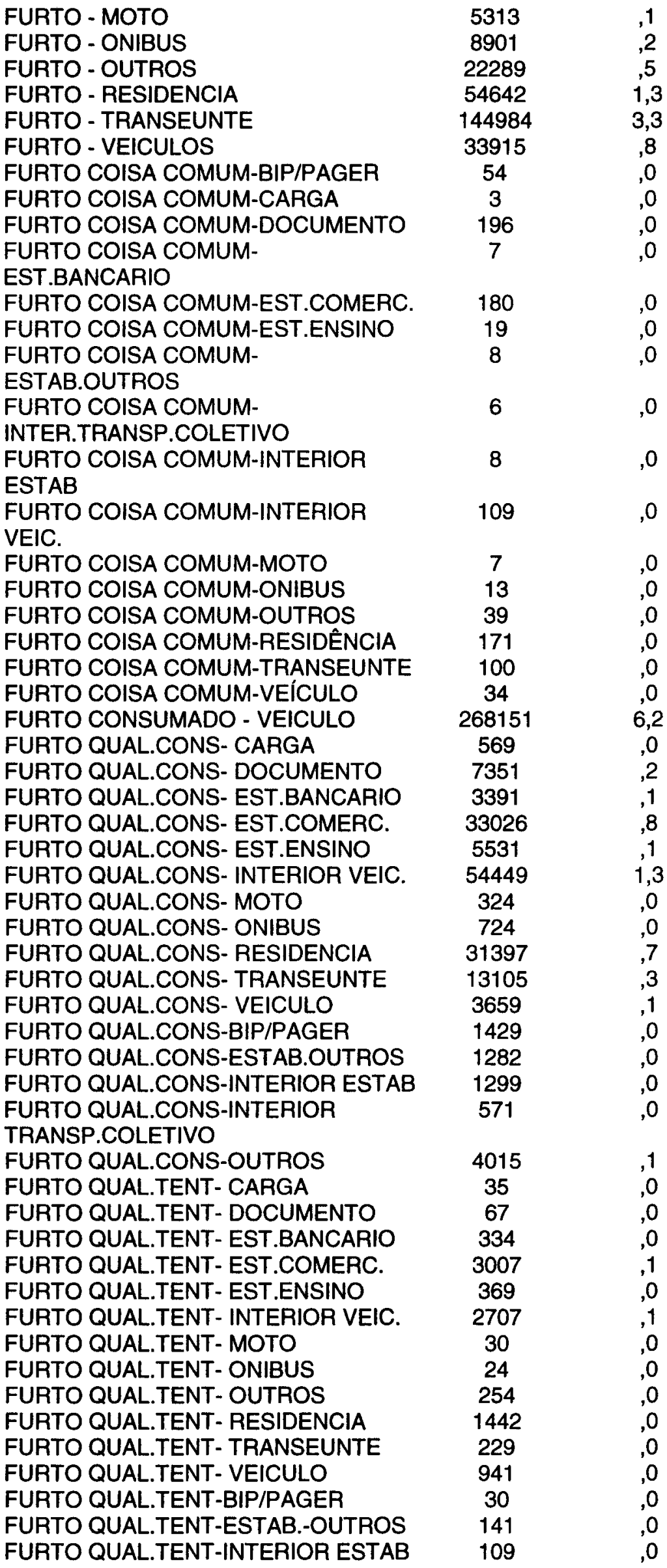




\begin{tabular}{|c|c|c|}
\hline \multicolumn{3}{|l|}{$\begin{array}{l}\text { FURTO QUAL.TENT-IN } \\
\text { TRANSP.COLETIVO }\end{array}$} \\
\hline FURTO TENTADO-BIP/PAGER & 81 & 0 \\
\hline FURTO TENTADO-CARGA & 107 & 0 \\
\hline FURTO TENTADO-DOCUMENTO & 206 & 0 \\
\hline FURTO TENTADO-EST.BANCARIO & 187 & 0 \\
\hline FURTO TENTADO-EST.COMERC. & 6312 & 1 \\
\hline FURTO TENTADO-EST.ENSINO & 379 & 0 \\
\hline FURTO TENTADO-ESTAB.OUTROS & 199 & 0 \\
\hline FURTO TENTADO-INTERIOR ESTAB & 278 & 0 \\
\hline $\begin{array}{l}\text { FURTO TENTADO-INTERIOR } \\
\text { TRANSP.COLETIVO }\end{array}$ & TRANSP.COLETIVO &, 0 \\
\hline FURTO TENTADO-INTERIOR VEIC. & 1809 & 0 \\
\hline FURTO TENTADO-MOTO & 71 & 0 \\
\hline FURTO TENTADO-ÔNIBUS & 59 & 0 \\
\hline FURTO TENTADO-OUTROS & 820 & 0 \\
\hline FURTO TENTADO-RESIDÊNCIA & 1657 &, 0 \\
\hline FURTO TENTADO-TRANSEUNTE & 1512 &, 0 \\
\hline FURTO TENTADO-VEICULO & 1325 & 0 \\
\hline FURTO TENTADO - VEICULO & 2182 &, 1 \\
\hline GENOCIDIO - LEI 2889/56 & 1 & 0 \\
\hline GREVE & 44 & 0 \\
\hline HOMICIDIO CULPOSO (ACID.TRANS) & 4224 & 1 \\
\hline HOMICIDIO CULPOSO OUTROS & 646 & 0 \\
\hline HOMICIDIO DOLOSO & 30445 &, 7 \\
\hline HOMICIDIO QUALIFICADO & 1119 & 0 \\
\hline IMITACAO DE MOEDA & 19 & 0 \\
\hline IMPEDIM.DE CERIMONIA FUNERARIA & 9 & 0 \\
\hline \multirow{2}{*}{\multicolumn{3}{|c|}{ PUDOR }} \\
\hline & & \\
\hline INCENDIO & 4336 & 1 \\
\hline INCENDIO TENTADO & 248 & 0 \\
\hline INCITACAO AO CRIME & 59 & 0 \\
\hline INDUZIMENTO A ERRO & 4 & 0 \\
\hline INDUZIMENTO A ESPECULACAO & 21 & 0 \\
\hline INDUZIR,INSTIGAR,AUX.SUICIDIO & 455 &, 0 \\
\hline INFANTICIDIO & 18 & 0 \\
\hline INFRACAO DE MEDIDA SANITARIA & 16 & 0 \\
\hline INJURIA & 46494 & 1,1 \\
\hline INJURIA REAL & 4789 & 1 \\
\hline INOVAR,ARTIF.EM CASO ACIDENTE & 8 & 0 \\
\hline INSTIT.FINANCEIRAS-L 4595/64 & 3 & 0 \\
\hline INSTRUMENTO P/PRATICA DE FURTO & 92 & 0 \\
\hline INT.IRREG.ESTABELECIMENTO PSIQ & 1 & 0 \\
\hline INTERCEPT.TELEFÔNICA-L.9296/96 & 17 & 0 \\
\hline INTRODUCAO DE ANIMAIS & 23 & 0 \\
\hline INUMACAO/EXUMACAO DE CADAVER & 3 & 0 \\
\hline INUNDACAO & 35 &, 0 \\
\hline INVASAO E SABOTAGEM & 26 & 0 \\
\hline JOGO DE AZAR & 581 & 0 \\
\hline JOGO DO BICHO & 1224 & 0 \\
\hline LAVAGEM BENS, VAL.-L.9613/98 & 1 & 0 \\
\hline LEI DE IMPRENSA-LEI 5520/67 & 12 & 0 \\
\hline LESAO CORP.CULP.ACID.TRANSITO & 98975 & 2,3 \\
\hline LESAO CORPORAL CULP DIR.VEIC. & 20876 &, 5 \\
\hline $\begin{array}{l}\text { LESAO CORPORAL CULPOSA } \\
\text { OUTROS }\end{array}$ & 11707 & ,3 \\
\hline LESAO CORPO & 197353 & 4,5 \\
\hline LIC.CONTR.ADM.PUBL.-L.8666/93 & 1 &, 0 \\
\hline LOCAL./APREEN./ENTR. DE OBJETO & 401 & 0 \\
\hline
\end{tabular}




\begin{tabular}{|c|c|c|}
\hline $\begin{array}{l}\text { LOTERIA IRREGULAR - DL 6259/44 } \\
\text { LOTERIA NAO AUTORIZADA }\end{array}$ & $\begin{array}{c}41 \\
9\end{array}$ & $\begin{array}{l}, 0 \\
, 0\end{array}$ \\
\hline MAUS TRATOS & 5334 & 1 \\
\hline MEDIACAO A LASCIVIA & 15 &, 0 \\
\hline MEIO AMBIENTE-L 9605/98 & 828 & 0 \\
\hline MENDICANCIA & 32 & 0 \\
\hline MOEDA FALSA & 2229 &, 1 \\
\hline MORDEDURA DE CAO & 443 & 0 \\
\hline MORTE A ESCLARECER & 25216 & 6 \\
\hline MOTIM DE PRESOS & 263 & 0 \\
\hline NÃO TABELADO & 2076 & 0 \\
\hline NEGACAO DE DIREITO TRABALHISTA & 105 & 0 \\
\hline OCULTACAO DE CADAVER & 59 & 0 \\
\hline OMIS.DE CAUTELA/GUARDA ANIMAIS & 1729 & 0 \\
\hline OMISSAO DE NOTIFIC.DE DOENCA & 2 &, 0 \\
\hline OMISSAO DE SINAIS DE PERIGO & 6 & 0 \\
\hline OMISSAO DE SOCORRO & 2115 & 0 \\
\hline OMISSAO/COMUNICACAO DE CRIME & 9 & 0 \\
\hline ORDEM ECONÔMICA- L 8176/91 & 53 & 0 \\
\hline OUTRAS CONTRAVENCOES & 688 & 0 \\
\hline OUTRAS FALSIDADES & 3137 & 1 \\
\hline OUTROS CRIMES C/ADMINISTRACAO & 756 & 0 \\
\hline OUTROS CRIMES CONTRA A SAUDE & 266 & 0 \\
\hline OUTROS NAO CRIMINAL & 28315 & 7 \\
\hline PARCELAM.SOLO URBANO-L.6766/79 & 25 & 0 \\
\hline PATROCINIO INFIEL & 30 & 0 \\
\hline PECULATO CULPOSO & 6 & 0 \\
\hline PECULATO DOLOSO & 106 & 0 \\
\hline PERDA DE ARMA & 772 & 0 \\
\hline PERDA/EXTRAVIO DE DOCUMENTOS & 302660 & 7,0 \\
\hline PERIGO CONTAGIO MOLESTIA GRAVE & 27 & 0 \\
\hline PERIGO DE CONTAGIO VENEREO & 29 & 0 \\
\hline PERIGO DE DESABAMENTO & 82 & 0 \\
\hline PERIGO DE DESASTRE FERROVIARIO & 49 & 0 \\
\hline PERIGO DE INUNDACAO & 9 & 0 \\
\hline PERIGO DE VIDA OU SAUDE & 1992 & 0 \\
\hline PERMITIR DIR.A NAO HABILITADO & 453 & 0 \\
\hline PERTURB.DE TRABALHO OU & 4754 & 1 \\
\hline $\begin{array}{l}\text { SOSSEGO } \\
\text { PERTURR SERV TFI FGR ITEI FEONIC }\end{array}$ & & \\
\hline $\begin{array}{l}\text { PERTURB.SERV.TELEGR./TELEFONIC } \\
\text { PERTURBACAO DA TRANOUILDADE }\end{array}$ & $\begin{array}{c}52 \\
6353\end{array}$ & 0 \\
\hline $\begin{array}{l}\text { PERTURBACAO DA TRANQUILIDADE } \\
\text { PETRECHO E FALSIFICACAO }\end{array}$ & $\begin{array}{c}6353 \\
67\end{array}$ & $\begin{array}{l}1 \\
, 0\end{array}$ \\
\hline PETRECHO P/FALSIFICACAO MOEDA & 7 & 0 \\
\hline PLANOS/BEN.PREV.SOC.-L.8213/91 & 9 & 0 \\
\hline $\begin{array}{l}\text { POLITICA NACIONAL MEIO AMBIENTE- } \\
\text { L6938/81 }\end{array}$ & 1 & 0 \\
\hline POLUICAO DE AGUA POTAVEL & 8 & 0 \\
\hline PORTE ARMA DE FOGO-L. $9437 / 97$ & 2748 &, 1 \\
\hline PORTE DE ARMA & 24544 & 6 \\
\hline PORTE DE ENTORPECENTE & 15526 &, 4 \\
\hline POSSE DE GAS & 43 & 0 \\
\hline POSSE INSTR.P/PRATICA DE FURTO & 128 & 0 \\
\hline POSSE SEXUAL MEDIANTE FRAUDE & 34 & 0 \\
\hline PRECONCEITO RACIAL LEI 7437/85 & 316 & 0 \\
\hline PRESCRICAO DE ENTORPECENTE & 9 & 0 \\
\hline PRESERVACAO DE DIREITOS & 102935 & 2,4 \\
\hline PREVARICACAO & 96 & 0 \\
\hline MOCAO DE FUGA & 249 & 0 \\
\hline PROPR.INTEL.SOFTWARE-L.9609/98 & 20 & 0 \\
\hline PROVOCACAO DE TUMULTO & 96 & 0 \\
\hline
\end{tabular}




\begin{tabular}{|c|c|c|}
\hline $\begin{array}{l}\text { QUADRILHA OU BANDO } \\
\text { QUEDA ACIDENTAL }\end{array}$ & $\begin{array}{l}2094 \\
2294\end{array}$ &, 0 \\
\hline & $\begin{array}{c}2294 \\
43\end{array}$ & $\begin{array}{l}.1 \\
, 0\end{array}$ \\
\hline RAPTO & 137 &, 0 \\
\hline RAPTO CONSENSUAL & 493 &, 0 \\
\hline RECEPTACAO CULPOSA - CARGA & 101 & 0 \\
\hline RECEPTACAO CULPOSA - OUTROS & 2532 & 1 \\
\hline RECEPTACAO CULPOSA - VEICULO & 73 &, 0 \\
\hline RECEPTACAO DOLOSA - CARGA & 899 & 0 \\
\hline RECEPTACAO DOLOSA - OUTROS & 15914 & ,4 \\
\hline RECEPTACAO DOLOSA - VEICULO & 1827 &, 0 \\
\hline RECUSA DE MOEDA & 18 & 0 \\
\hline RECUSA INFOR.DADOS IDENTIDADE & 54 & 0 \\
\hline REDUÇĀO COND.ANALOGA ESCRAVO & 2 & 0 \\
\hline RESISTENCIA & 6674 & ,2 \\
\hline RETENCAO DE DOCUMENTO-LEI & 698 &, 0 \\
\hline $5553 / 68$ & & \\
\hline RIXA & 343 & 0 \\
\hline ROUBO-INTERIOR TRANSP.COLETIVO & 5248 & 1 \\
\hline ROUBO - ESTAB.OUTROS & 1121 &, 0 \\
\hline ROUBO - INTERIOR ESTEB. & 2012 &, 0 \\
\hline ROUBO CONSUMADO -- CARGA & 20885 &, 5 \\
\hline ROUBO CONSUMADO - DOCUMENTO & 46137 & 1,1 \\
\hline ROUBO CONSUMADO - INTERIOR & 59939 & 1,4 \\
\hline VEIC. & & \\
\hline ROUBO CONSUMADO - MOTO & 10348 & ,2 \\
\hline ROUBO CONSUMADO - ONIBUS & 59696 & 1,4 \\
\hline ROUBO CONSUMADO - OUTROS & 54873 & 1,3 \\
\hline ROUBO CONSUMADO - VEICULO & 34274 & 8 \\
\hline $\begin{array}{l}\text { ROUBO CONSUMADO - } \\
\text { EST BANCARIO }\end{array}$ & 3307 & 1 \\
\hline ROUBO CONSUMADO - EST.COMERC. & 83095 & 1,9 \\
\hline ROUBO CONSUMADO - EST.ENSINO & 935 &, 0 \\
\hline ROUBO CONSUMADO - RESIDENCIA & 14406 & 3 \\
\hline ROUBO CONSUMADO - TRANSEUNTE & 313971 & 7,2 \\
\hline ROUBO CONSUMADO - VEICULO & 264018 & 6,1 \\
\hline ROUBO SEGUIDO MORTE-CARGA & 11 &, 0 \\
\hline ROUBO SEGUIDO MORTE- & 6 & 0 \\
\hline $\begin{array}{l}\text { DOCUMENTO } \\
\text { ROUBO SEGUIDO MORTE- }\end{array}$ & 7 & 0 \\
\hline EST.BANCARIO & $r$ & \\
\hline ROUBO SEGUIDO MORTE- & 314 & 0 \\
\hline EST.COMERC. & & \\
\hline $\begin{array}{l}\text { ROUBO SEGUIDO MORTE- } \\
\text { EST.ENSINO }\end{array}$ & 3 &, 0 \\
\hline $\begin{array}{l}\text { ROUBO SEGUIDO MORTE- } \\
\text { INT.TRANSP.COLETIVO }\end{array}$ & 5 &, 0 \\
\hline $\begin{array}{l}\text { ROUBO SEGUIDO MORTE-INTERIOR } \\
\text { ESTAB }\end{array}$ & 10 &, 0 \\
\hline $\begin{array}{l}\text { ROUBO SEGUIDO MORTE-INTERIOR } \\
\text { VEIC. }\end{array}$ & 100 &, 0 \\
\hline ROUBO SEGUIDO MORTE-MOTO & 66 &, 0 \\
\hline ROUBO SEGUIDO MORTE-ÓNIBUS & 26 &, 0 \\
\hline ROUBO SEGUIDO MORTE-OUTROS & 166 & 0 \\
\hline $\begin{array}{l}\text { ROUBO SEGUIDO MORTE- } \\
\text { RESIDÊNGIA }\end{array}$ & 96 &, 0 \\
\hline $\begin{array}{l}\text { ROUBO SEGUIDO MORTE- } \\
\text { TRANSEUNTE }\end{array}$ & 228 & 0 \\
\hline ROUBO SEGUIDO MORTE-VEÍCULO & 229 & 0 \\
\hline ROUBO TENTADO-INT.TRANSP.COLE & 159 & 0 \\
\hline
\end{tabular}




\begin{tabular}{|c|c|c|}
\hline $\begin{array}{l}\text { ROUBO TENTADO - CARGA } \\
\text { ROUBO TENTADO - DOCUMENTO }\end{array}$ & $\begin{array}{l}548 \\
141\end{array}$ & $\begin{array}{l}0 \\
.0\end{array}$ \\
\hline ROUBO TENTADO - EST.BANCARIO & 222 & 0 \\
\hline ROUBO TENTADO - EST.COMERC. & 3135 &, 1 \\
\hline ROUBO TENTADO - EST.ENSINO & 60 & 0 \\
\hline ROUBO TENTADO - ESTAB.OUTROS & 79 & 0 \\
\hline ROUBO TENTADO - INTERIOR ESTAB. & 94 &, 0 \\
\hline ROUBO TENTADO - INTERIOR VEIC. & 1539 & 0 \\
\hline ROUBO TENTADO - MOTO & 469 & 0 \\
\hline ROUBO TENTADO - ONIBUS & 560 & 0 \\
\hline ROUBO TENTADO - OUTROS & 2168 & 0 \\
\hline ROUBO TENTADO - RESIDENCIA & 978 & 0 \\
\hline ROUBO TENTADO - TRANSEUNTE & 5947 &, 1 \\
\hline ROUBO TENTADO - VEICULO & 7463 & , 2 \\
\hline ROUBO/FURTO DE DOCUMENTO & 4031 &, 1 \\
\hline ROUBO+LESAO GRAVE-CARGA & 5 & 0 \\
\hline ROUBO+LESAO GRAVE-DOCUMENTO & 23 & 0 \\
\hline ROUBO+LESAO GRAVE- & 3 & 0 \\
\hline $\begin{array}{l}\text { EST.BANCARIO } \\
\text { ROUBO+LESAO GRAVE-EST.COMERC. }\end{array}$ & & 0 \\
\hline ROUBO+LESAO GRAVE-EST.ENSINO & 3 & ,0 \\
\hline ROUBO+LESAO GRAVE-INTERIOR & 122 & 0 \\
\hline VEIC. & & \\
\hline ROUBO+LESAO GRAVE-MOTO & 47 & 0 \\
\hline ROUBO+LESAO GRAVE-ÔNIBUS & 33 & 0 \\
\hline ROUBO+LESAO GRAVE-OUTROS & 135 & 0 \\
\hline ROUBO+LESAO GRAVE-RESIDÊNCIA & 64 & 0 \\
\hline ROUBO+LESAO GRAVE-TRANSEUNTE & 466 & 0 \\
\hline ROUBO+LESAO GRAVE-VEÍCULO & 168 & 0 \\
\hline RUFIANISMO & 36 & 0 \\
\hline SEDUCAO & 344 & 0 \\
\hline SEQUESTRO & 1205 & 0 \\
\hline SEQUESTRO/CARCERE PRIVADO & 654 & 0 \\
\hline SERV.TELECOMUN.-L.9472/97 & 28 & 0 \\
\hline SIMULACAO QUALID. FUNCIONARIO & 219 & 0 \\
\hline SONEGACAO DE INCAPAZES & 153 & 0 \\
\hline SONEGACAO FISCAL & 1254 & 0 \\
\hline SONEGACAO/ESTADO DE FILIACAO & 9 & 0 \\
\hline SUBTRACAO DE INCAPAZES & 707 & 0 \\
\hline SUICIDIO CONSUMADO & 2167 & 0 \\
\hline SUICIDIO TENTADO & 2448 & 1 \\
\hline SUPRESSAO DE DOCUMENTO & 1434 & 0 \\
\hline SVO - VERIFICACAO DE OBITO & 75568 & 1,7 \\
\hline TENTATIVA DE HOMICIDIO & 17607 & ,4 \\
\hline TOMBAMENTO & 127 & 0 \\
\hline TORTURA- L 9455/97 & 15 & 0 \\
\hline TRAFEGAR VELOC. INCOMPATIVEL & 269 & 0 \\
\hline TRAFICO DE MULHERES & 2 & 0 \\
\hline TRAFICO ENTORPECENTE- - OUTROS & 8218 & ,2 \\
\hline $\begin{array}{l}\text { TRAFICO ENTORPECENTE- } \\
\text { PSICOTROP }\end{array}$ & 198 & 0 \\
\hline TRAFICO ENTORPECENTE - & 3302 &, 1 \\
\hline & & \\
\hline ULTRAJE A CULTO & 47 & O \\
\hline USO DE DOCUMENTO FALSO & 5302 & , \\
\hline $\begin{array}{l}\text { USO DE ENTORPECENTE- } \\
\text { PSICOTROP }\end{array}$ & 14 & 0 \\
\hline & & \\
\hline USO DE ENTORPECENTE - MACONHA & 985 & 0 \\
\hline USO DE ENTORPECENTE - OUTROS & 279 & 0 \\
\hline USO DE GAS & 16 & \\
\hline
\end{tabular}


USO ILEGIT.UNIFORME/DISTINTIVO USO INDEVIDO DE SIMBOLOS

USURPACAO

USURPACAO DE FUNCAO

USURPACAO DE MODELO

USURPACAO DE NOME/PSEUDONIMO

VADIAGEM

VEICULO LOCALIZADO

VENDA ILICITA BEBIDA ALCOOLICA

VIAS DE FATO

VILIPENDIO A CADAVER

VIOLAC.TELECOMUNIC.LEI 4117/62

VIOLACAO DE CORRESPONDENCIA

VIOLACAO DE DIREITO AUTORAL

VIOLACAO DE DIREITO DE MARCA

VIOLACAO DE DOMICILIO

VIOLACAO DE LUGAR OU OBJETO

VIOLACAO DE SEPULTURA

VIOLACAO DE SIGILO

VIOLACAO PRIVILÉGIO E INVENÇAO

VIOLACAO SEGREDO PROFISSIONAL

VIOLACAO SUSPENSAO/PROIBIÇÃO

VIOLENCIA ARBITRARIA

Total

$\begin{array}{cc}106 & , 0 \\ 1 & , 0 \\ 40 & , 0 \\ 162 & , 0 \\ 3 & , 0 \\ 4 & , 0 \\ 78 & , 0 \\ 263270 & 6,0 \\ 79 & , 0 \\ 21670 & , 5 \\ 16 & , 0 \\ 432 & , 0 \\ 425 & , 0 \\ 739 & , 0 \\ 61 & , 0 \\ 3284 & , 1 \\ 262 & , 0 \\ 141 & , 0 \\ 13 & , 0 \\ 5 & , 0 \\ 24 & , 0 \\ 16 & , 0 \\ 24 & , 0 \\ \mathbf{4 . 3 5 2 . 6 9 7} & 100,0\end{array}$

\section{A3 - Exemplo de correção de base de DP's.}

\section{- Inconsistências na base de DP's}

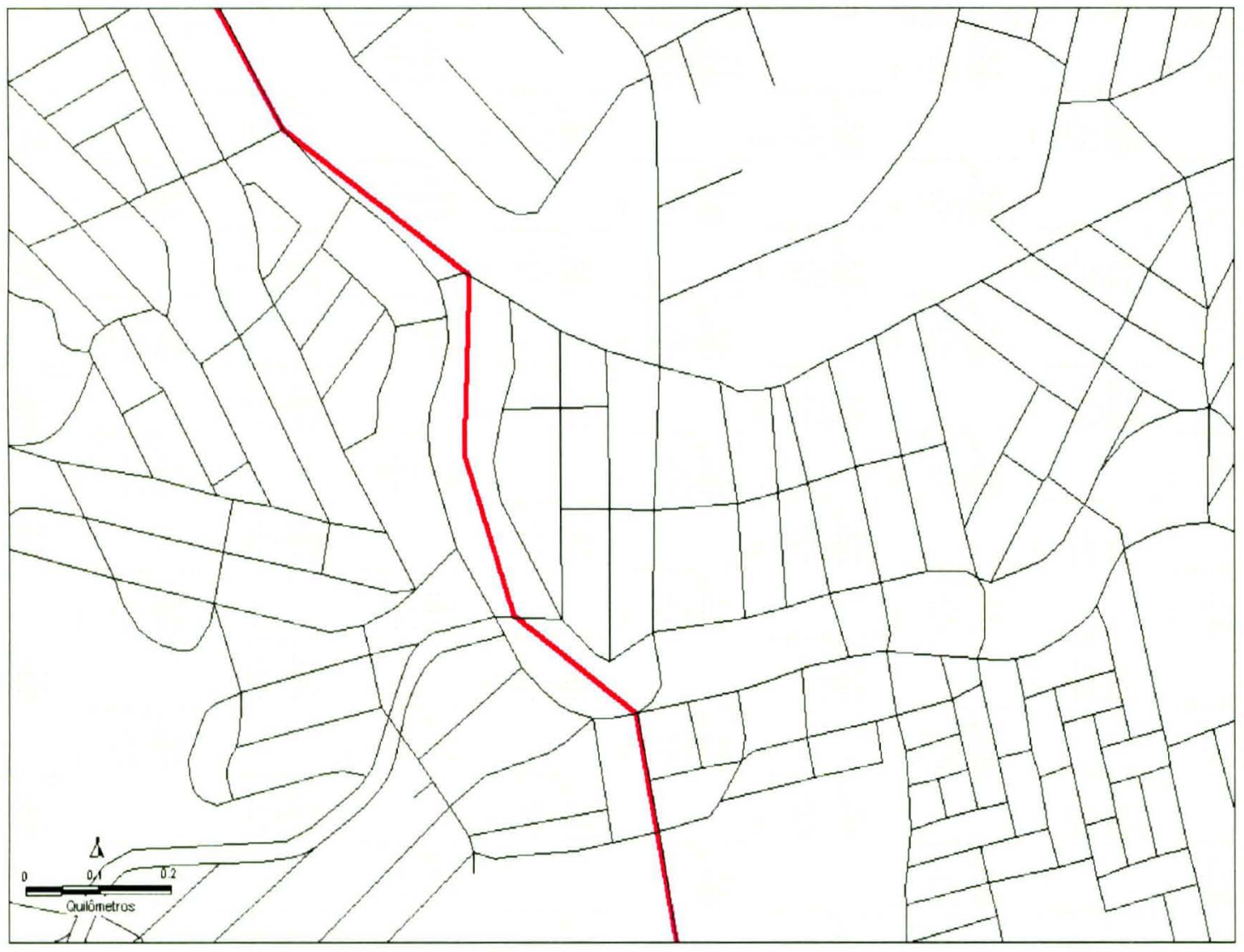


- Correções elaboradas em escala de detalhe (1:2.000)

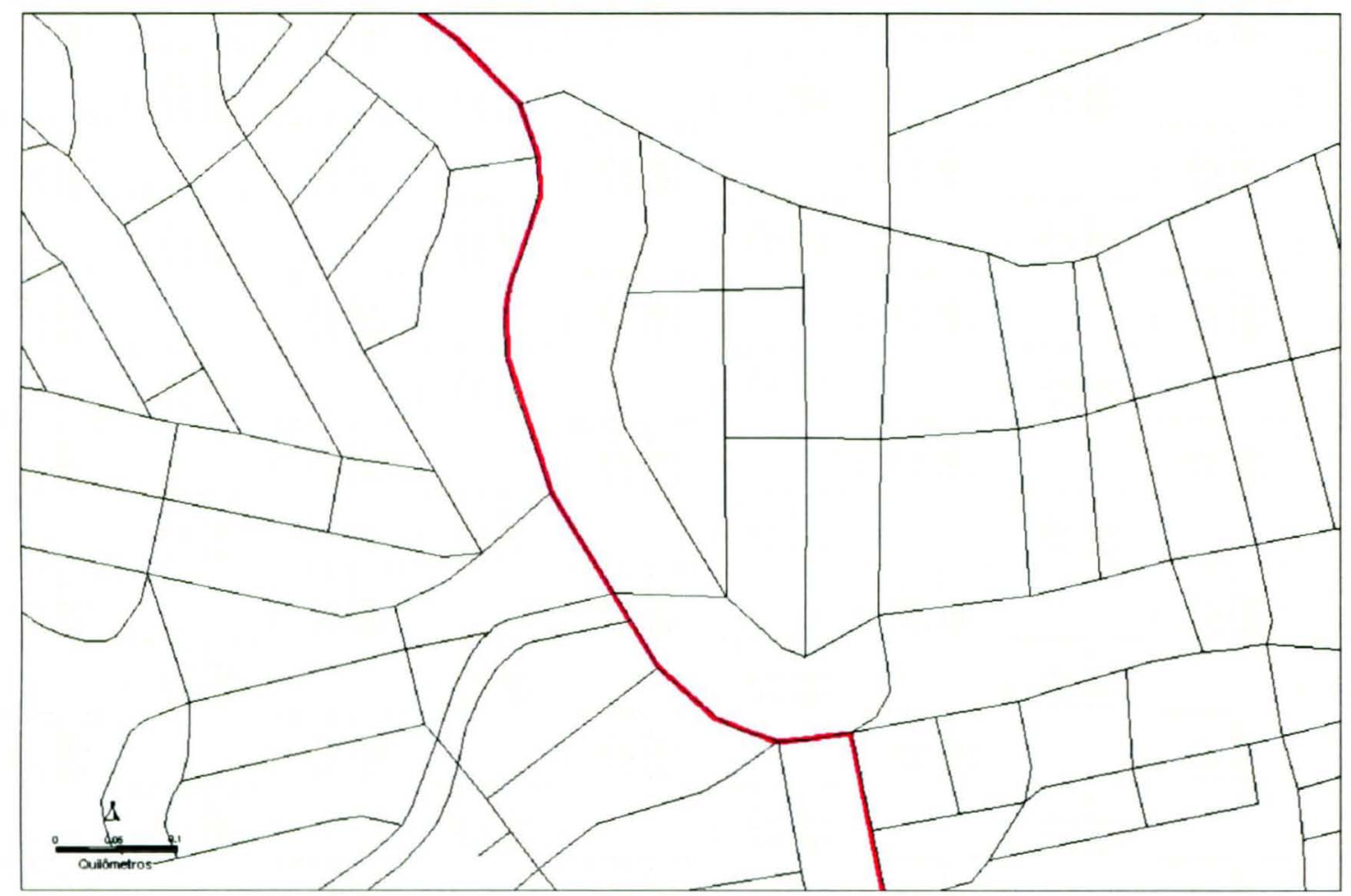

A4 - "Estilos de simbologia."

\begin{tabular}{|l|l|l|l|}
\hline Base & Símbolo (fonte/cor/tamanho) & $\begin{array}{l}\text { Linha } \\
\text { (estilo/cor/espes } \\
\text { sura) }\end{array}$ & $\begin{array}{l}\frac{\text { Polígono }}{\text { (preenchimento/ tipo - }} \\
\text { espessura de linha } \\
\text { Meor) }\end{array}$ \\
\hline Metrô & $\begin{array}{l}\text { Maplnfo Transportation/ vermelho } \\
\text { (linha Norte), azul (linha Sul), } \\
\text { verde (oeste), lilás (sudoeste)/18 }\end{array}$ & $\begin{array}{l}\text { traço } \\
\text { contínuo/vermelh } \\
\text { o/02 }\end{array}$ & - \\
\hline Trem & Símbolo Personalisados/ preto/14 & - & - \\
\hline $\begin{array}{l}\text { Terminal de } \\
\text { e intermunicipal) }\end{array}$ & Mapinfo Transportation/preto/16 & - & - \\
\hline $\begin{array}{l}\text { Rede de Ensino } \\
\text { (pública e privada) }\end{array}$ & Maplnfo Miscellaneous/preto/30 & - & - \\
\hline
\end{tabular}




\begin{tabular}{|c|c|c|c|}
\hline $\begin{array}{l}\text { Agência Bancária } \\
\text { e } \\
\text { Caixa Eletrônico }\end{array}$ & $\begin{array}{l}\text { Maplnfo Real Estate/cinza } \\
\text { chumbo/32 }\end{array}$ & - & - \\
\hline Favela & - & - & $\begin{array}{l}\text { Com } \\
\text { preenchimento/traço } \\
\text { contínuo-01/ roxo claro }\end{array}$ \\
\hline Rede de Saúde & Maplnfo Symbols/ vermelho/36 & - & - \\
\hline Shopping & $\begin{array}{l}\text { Símbolos } \\
\text { personalizados/verde/36 }\end{array}$ & - & - \\
\hline Rua & - & $\begin{array}{l}\text { traço } \\
\text { contínuo/preto/01 }\end{array}$ & - \\
\hline Via Principal & - & $\begin{array}{l}\text { traço } \\
\text { contínuo/amarelo } \\
\text { /08 }\end{array}$ & - \\
\hline Estada/Rodovia & - & $\begin{array}{l}\text { traço } \\
\text { contínuo/vermelh } \\
\text { o/08 }\end{array}$ & - \\
\hline Túnel/Viaduto & - & $\begin{array}{l}\text { traço } \\
\text { contínuo/cinza/08 }\end{array}$ & - \\
\hline Acesso & - & $\begin{array}{l}\text { traço } \\
\text { contínuo/preto/08 }\end{array}$ & - \\
\hline Distrito Policial & - & - & $\begin{array}{l}\text { Com } \\
\text { preenchimento/amarelo } \\
\text { claro/traço contínuo-05 } \\
\text { /preto }\end{array}$ \\
\hline
\end{tabular}




\begin{tabular}{|c|c|c|c|}
\hline Sede de DP & Map/nfo Real Estate/mostarda/48 & - & - \\
\hline Base Comunitária & Maplnfo Real Estate/mostarda/48 & - & - \\
\hline Rio e córrego & - & $\begin{array}{l}\text { traço } \\
\text { contínuo/azul } \\
\text { claro/01 }\end{array}$ & - \\
\hline Lago & $1-$ & - & $\begin{array}{l}\text { Sem } \\
\text { preenchimento/traço } \\
\text { contínuo-01 / azul claro }\end{array}$ \\
\hline $\begin{array}{l}\text { Limite de } \\
\text { municipios }\end{array}$ & - & - & $\begin{array}{l}\text { Sem } \\
\text { preenchimento/traço } \\
\text { contínuo-02 / preto }\end{array}$ \\
\hline Praça & - & - & $\begin{array}{l}\text { Com } \\
\text { preenchimento/traço } \\
\text { contínuo-01 / verde claro }\end{array}$ \\
\hline $\begin{array}{l}\text { Área pública } \\
\text { (clubes, estádios, } \\
\text { cemitérios,etc.) }\end{array}$ & - & - & $\begin{array}{l}\text { Com } \\
\text { preenchimento/traço } \\
\text { contínuo-01/verde } \\
\text { escuro }\end{array}$ \\
\hline $\begin{array}{l}\text { Boletim de } \\
\text { Ocorrência }\end{array}$ & $\begin{array}{l}\text { Compatíveis com Maplnfo } \\
\text { 3.0/azul (dia), preto (noite) e } \\
\text { vermelho (desconhecido)/30 }\end{array}$ & - & - \\
\hline
\end{tabular}


A5 - Lista com nomes e respectivos números de Distritos Policias (DP).

\begin{tabular}{|c|c|c|c|}
\hline NOME DP & $\mathbf{N}^{\circ} \mathrm{DP}$ & NOME DP & $\mathbf{N}^{\circ} \mathbf{D P}$ \\
\hline Sé & 1 & Cidade Dutra & 48 \\
\hline Bom Retiro & 2 & São Matheus & 49 \\
\hline Campos Elíseos & 3 & Itaim Paulista & 50 \\
\hline Consolação & 4 & Rio Pequeno & 51 \\
\hline Aclimação & 5 & Parque São Jorge & 52 \\
\hline Cambuci & 6 & Parque do Carmo & 53 \\
\hline Lapa & 7 & Cid Tiradentes & 54 \\
\hline Brás & 8 & Pq São Rafael & 55 \\
\hline Carandiru & 9 & Vila Alpina & 56 \\
\hline Penha de Franca & 10 & Parque da Moôca & 57 \\
\hline Santo Amaro & 11 & VI Formosa & 58 \\
\hline Pari & 12 & Jardim dos Ipes & 59 \\
\hline Casa Verde & 13 & Jardim Popular & 62 \\
\hline Pinheiros & 14 & Vila Jacui & 63 \\
\hline Indianópolis & 15 & Cidade AE Carvalho & 64 \\
\hline Vila Clementino & 16 & Artur Alvim & 65 \\
\hline Ipiranga & 17 & Vale Aricanduva & 66 \\
\hline Alto da Moôca & 18 & Jardim Robru & 67 \\
\hline Vila Maria & 19 & Lajeado & 68 \\
\hline Água Fria & 20 & Teotônio Vilela & 69 \\
\hline Vila Matilde & 21 & Vila Ema & 70 \\
\hline $\begin{array}{l}\text { São Miguel } \\
\text { Paulista }\end{array}$ & 22 & VI Penteado & 72 \\
\hline Perdizes & 23 & Jaçana & 73 \\
\hline $\begin{array}{l}\text { Ermelino } \\
\text { Matarazzo }\end{array}$ & 24 & Parada Taipas & 74 \\
\hline Parelheiros & 25 & Jardim Arpoador & 75 \\
\hline Sacomã & 26 & Santa Cecília & 77 \\
\hline Ibirapuera & 27 & Jardins & 78 \\
\hline Freguesia do 0 & 28 & VI Joaniza & 80 \\
\hline Vila Prudente & 29 & Belém & 81 \\
\hline Tatuapé & 30 & Parque Bristol & 83 \\
\hline Vila Carrão & 31 & \begin{tabular}{|l} 
Jardim Mirna \\
\end{tabular} & 85 \\
\hline Itaquera & 32 & Pereira Barreto & 87 \\
\hline Pirituba & 33 & Jardim Tamoio & 89 \\
\hline Morumbi & 34 & Pq Novo Mundo & 90 \\
\hline Jabaquara & 35 & Ceasa & 91 \\
\hline Vila Mariana & 36 & Pq Santo Antônio & 92 \\
\hline Campo Limpo & 37 & Jaguare & 93 \\
\hline Vila Amalia & 38 & Helinópolis & 95 \\
\hline Vila Gustavo & 39 & Monções & 96 \\
\hline VI Santa Maria & 40 & Americanópolis & 97 \\
\hline Vila Rica & 41 & Jardim Miriam & 98 \\
\hline Parque São Lucas & 42 & Campo Grande & 99 \\
\hline Cidade Ademar & 43 & Jd Herculano & 100 \\
\hline Guaianazes & 44 & Jd das Imbuias & 101 \\
\hline VI Brasilândia & 45 & Socorro & 102 \\
\hline Perus & 46 & Coahab II - Itaquera & 103 \\
\hline Capão Redondo & 47 & & \\
\hline
\end{tabular}

Fonte: Secretaria de Segurança Pública do Estado de São Paulo (2004). 
A6 - Proporções dos diversos tipos de crime dentro de cada agrupamento de DP's.

\begin{tabular}{|c|c|c|c|c|c|c|}
\hline \multirow[b]{2}{*}{ Tipo de crime } & \multicolumn{6}{|l|}{ Grupo } \\
\hline & 1 & 2 & 3 & 4 & 5 & 6 \\
\hline Estupro & $0,50 \%$ & $0,15 \%$ & $0,39 \%$ & $0,25 \%$ & $0,18 \%$ & $0,07 \%$ \\
\hline Furto de cargas & $0,20 \%$ & $0,14 \%$ & $0,20 \%$ & $0,08 \%$ & $0,43 \%$ & $0,52 \%$ \\
\hline Furto de estabelecimentos & $4,60 \%$ & $7,46 \%$ & $6,10 \%$ & $4,53 \%$ & $5,70 \%$ & $5,52 \%$ \\
\hline Furto outros & $0,23 \%$ & $0,50 \%$ & $0,02 \%$ & $0,36 \%$ & $0,30 \%$ & $0,01 \%$ \\
\hline Furto de pessoas & $4,80 \%$ & $8,79 \%$ & $6,69 \%$ & $5,12 \%$ & $5,65 \%$ & $9,94 \%$ \\
\hline Furto de residências & $4,01 \%$ & $3,78 \%$ & $5,12 \%$ & $3,22 \%$ & $4,04 \%$ & $1,11 \%$ \\
\hline Furto a transeunte & $3,85 \%$ & $9,35 \%$ & $7,07 \%$ & $4,65 \%$ & $4,25 \%$ & $35,56 \%$ \\
\hline Furto de transporte coletivo & $0,48 \%$ & $0,55 \%$ & $0,46 \%$ & $0,70 \%$ & $0,43 \%$ & $0,18 \%$ \\
\hline Furto de veículos & $12,47 \%$ & $26,64 \%$ & $18,74 \%$ & $18,45 \%$ & $26,62 \%$ & $9,29 \%$ \\
\hline Homicídios dolosos & $5,10 \%$ & $0,44 \%$ & $2,17 \%$ & $1,56 \%$ & $0,83 \%$ & $0,56 \%$ \\
\hline Roubo de cargas & $1,91 \%$ & $0,64 \%$ & $1,08 \%$ & $1,15 \%$ & $2,35 \%$ & $0,63 \%$ \\
\hline Roubo de estabelecimentos & $4,16 \%$ & $4,46 \%$ & $5,09 \%$ & $3,55 \%$ & $4,27 \%$ & $1,81 \%$ \\
\hline Roubos seguidos de lesão grave ou morte & $0,20 \%$ & $0,10 \%$ & $0,22 \%$ & $0,16 \%$ & $0,10 \%$ & $0,04 \%$ \\
\hline Roubo outros & $3,60 \%$ & $2,51 \%$ & $2,08 \%$ & $2,92 \%$ & $1,92 \%$ & $0,82 \%$ \\
\hline Roubo de pessoas & $3,91 \%$ & $2,18 \%$ & $2,62 \%$ & $3,58 \%$ & $2,76 \%$ & $1,53 \%$ \\
\hline Roubo de residências & $0,86 \%$ & $0,61 \%$ & $0,67 \%$ & $0,67 \%$ & $0,70 \%$ & $0,25 \%$ \\
\hline Roubo a transeunte & $13,68 \%$ & $17,17 \%$ & $16,50 \%$ & $15,94 \%$ & $12,58 \%$ & $28,02 \%$ \\
\hline Roubo de transporte coletivo & $9,09 \%$ & $0,66 \%$ & $5,90 \%$ & $5,27 \%$ & $1,44 \%$ & $0,13 \%$ \\
\hline Roubo de veículos & $25,31 \%$ & $13,41 \%$ & $18,03 \%$ & $27,20 \%$ & $24,85 \%$ & $3,34 \%$ \\
\hline Seqüestro & $0,22 \%$ & $0,07 \%$ & $0,13 \%$ & $0,15 \%$ & $0,09 \%$ & $0,03 \%$ \\
\hline Tráfico de entorpecente & $0,81 \%$ & $0,42 \%$ & $0,72 \%$ & $0,47 \%$ & $0,52 \%$ & $0,62 \%$ \\
\hline Total & $100,00 \%$ & $100,00 \%$ & $100,00 \%$ & $100,00 \%$ & $100,00 \%$ & $100,00 \%$ \\
\hline
\end{tabular}

Fonte: Elaborado pela autora. 


\section{A7 - Análise Discriminante.}

A partir da criação dos grupos, pela Análise de Agrupamento ("Cluster"), pode-se aplicar este tipo a técnica de Análise Discriminante, com o objetivo de classificar novas observações nos grupos formados. Com o uso desse tipo de técnica de agrupamento, observa-se um problema fundamental "Qual é o número de agrupamentos mais adequado para separar os Distritos em grupos homogêneos?". Para responder a essa questão, podem ser selecionados alguns conjuntos de agrupamentos como candidatos. A partir do uso de Análise Discriminante, é possível comparar esses agrupamentos candidatos e entender como as variáveis utilizadas nessas análises se relacionam com os agrupamentos.

$\mathrm{Na}$ Análise Discriminante, estima-se funções discriminantes que podem melhor explicar a diferença entre os agrupamentos. Assim, olhando o gráfico dessas funções discriminantes, pode-se analisar se realmente os seus integrantes devem pertencer a um mesmo grupo, ou seja, é possivel avaliar a homogeneidade dos grupos criados. A figura, abaixo, representa uma sintaxe utilizada para realização deste tipo de análise.

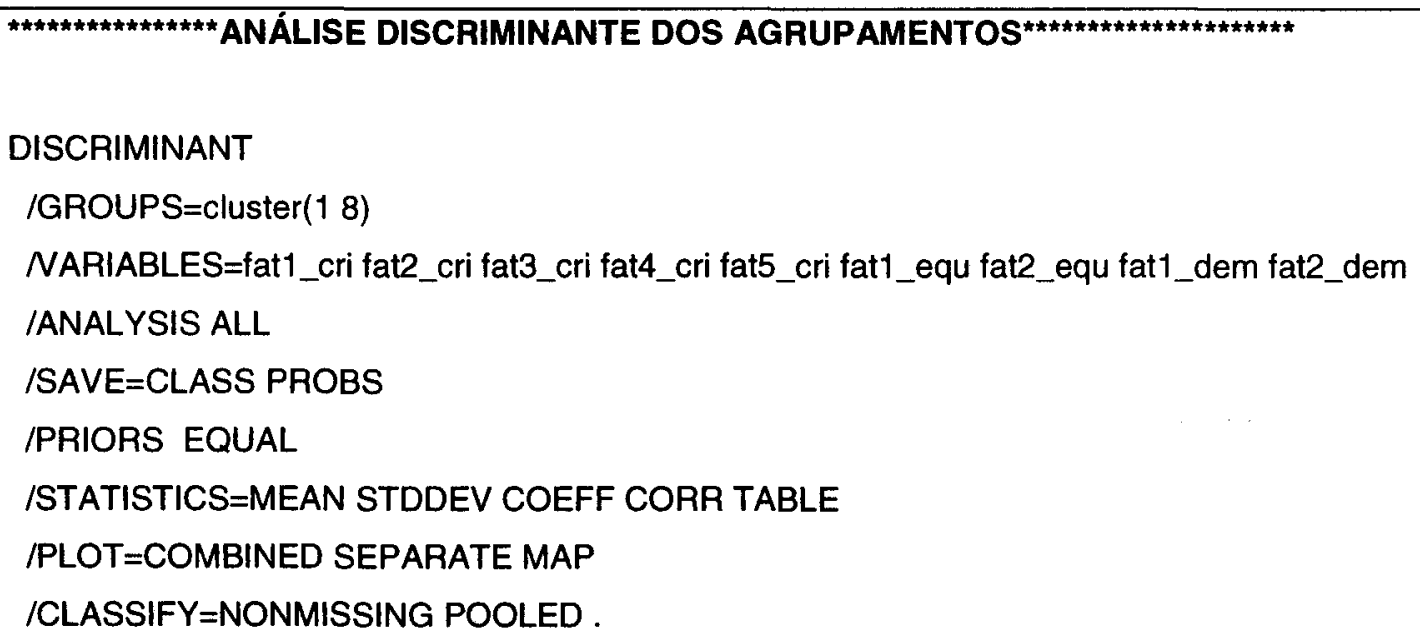


A8 - Identificação de inconsistências na base de sub-setores policiais no município de São Paulo.

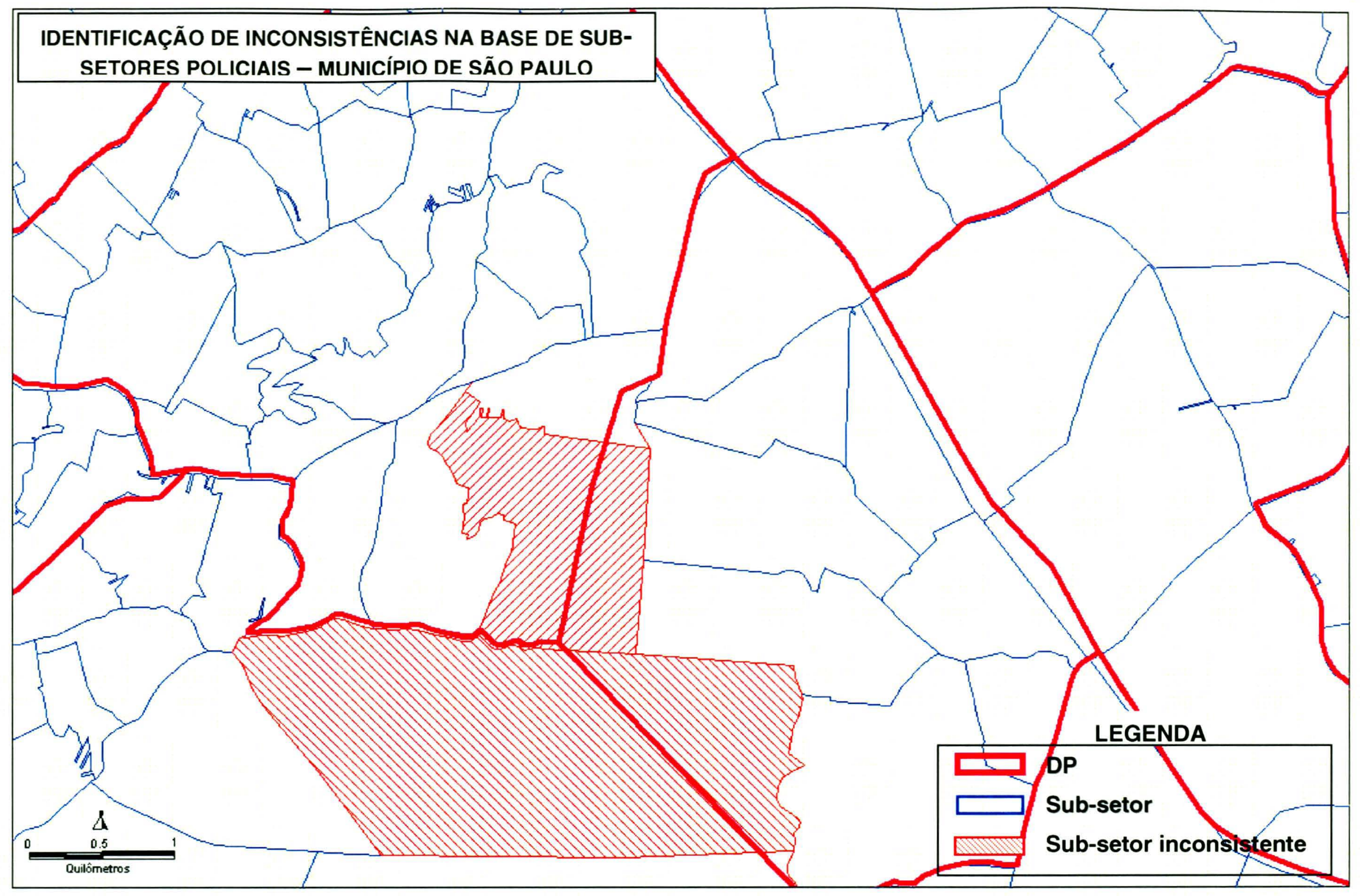


Adquirido por compra

Financlador

Fornecedor Sow de Animonometo

nacebido em

1912.05 


\section{ERRATA}

\section{JUSTIFICATIVA}

Página 09, quarto parágrafo: "Esta pesquisa se propõe...", e não "Em nossa pesquisa, nos propomos...".

\section{REVISÃO BIBLIOGRÁFICA}

Página 13, quinto parágrafo: “... em meados do século XIX...", e não "... em fins do século XIX...".

Página 22, segundo parágrafo: "No item a segui será discutido...", e não "No item a seguir discutiremos...".

Página 23, nota de rodapé, os ítens 11 e 12, referem-se a fonte Koogan Larousse (1979).

Página 25, segundo parágrafo: "Segundo Carvalho...", e não "Segundo o Carvalho...".

Página 26, segundo parágrafo: o nome correto é geoprocessamento, e não geoprocessametno.

Página 27, segundo parágrafo: “... indexados...", o correto é “... indexado...".

Página 46, sexto parágrafo: “... abordem...", o correto é "... abordaram...".

Página 56, primeiro parágrafo: “... informáticas...", o correto é "... informática...".

Página 58, segundo parágrafo: “... distintos...”, o correto é “... distintas...”. , terceiro parágrafo: “... pesquisadas...”, o correto é “... pesquisados...”.

Página 59, "Quadro 5": os anos de 2001, 2002, 2003 e 2004 não apresentam casas decimais.

Página 63, quarto parágrafo: o número correto de domicílios é 228, e não 220.

Página 66, quarto parágrafo: "... dos DP's, estes tiveram...", e não “... dos DP's tiveram...".

Página 71, quinto parágrafo: "Com efeito, as técnicas de análise num Sistema de Informação Geográfica podem ter diferentes níveis de complexidade, conforme o exemplo da tabela abaixo.", o correto é "Com efeito, as técnicas de análise num Sistema de Informação Geográfica podem ter diferentes níveis de complexidade". 
Página 72, terceiro parágrafo: o correto é "Outra taxonomia utilizada para caracterizar problemas no espaço são os eventos ou padrões pontuais...", e não "Outra taxonomia utilizada para caracterizar os problemas de análise espacial denominasse eventos ou padrões pontuais...", como está escrito.

Página 86, primeiro parágrafo: o correto é Figura 09, e não Figura $X$.

Página 97, Figura 14 - Tentativa de Homicídio - Capão Redondo, o correto é Figura 14 - Latrocínio - Capão Redondo.

Página 85, terceiro parágrafo: “...(Figura 07)...” e não, “... (“Clusters sócioeconômicos" por setor censitário)...". , quarto parágrafo: o correto é Figura 8, e não Figura 9.

Página 88, o correto é “... de também estar...", e não “... de também de estar...".

Página 89, o correto é “... a existência de transportes coletivos...”, e não “... a existência de entroncamentos de vias de trânsito e de transportes coletivos...".

\section{REFERÊNCIAS}

Fontes citadas no texto e ausentes em Referências.

Alvarenga AT. A saúde Publica como campo de investigação interdisciplinar e a questão metodológica. Saúde e Sociedade 1994; 3(2): 23-41.

Diniz NMF e Col. Mulher, saúde e violência: o espaço público e o privado. 0 Mundo da Saúde 1999. São Paulo. 23 (2), p.106-112

Libault A. Os quatro níveis da pesquisa Geográfica, in Método em Questão, 1 IGEOG-USP, São Paulo; 1971.

Rosa R, Santos MAF, Souza LHF. Mapeamento de homicídios em Uberlândia/MG entre 1999 e 2002 utilizando o software Arcview. Caminhos de Geografia 2005; 3 (14): 27-45.

Ross JLS. Geomorfologia: Ambiente e planejamento. São Paulo: Contexto; 2000.

Sorre M. A adaptação ao meio climático e biossocial - Geografia Psicológica. In Megale JF (org). Max Sorre. São Paulo, 1984 (Coleção Grandes Cientistas Sociais 46). 


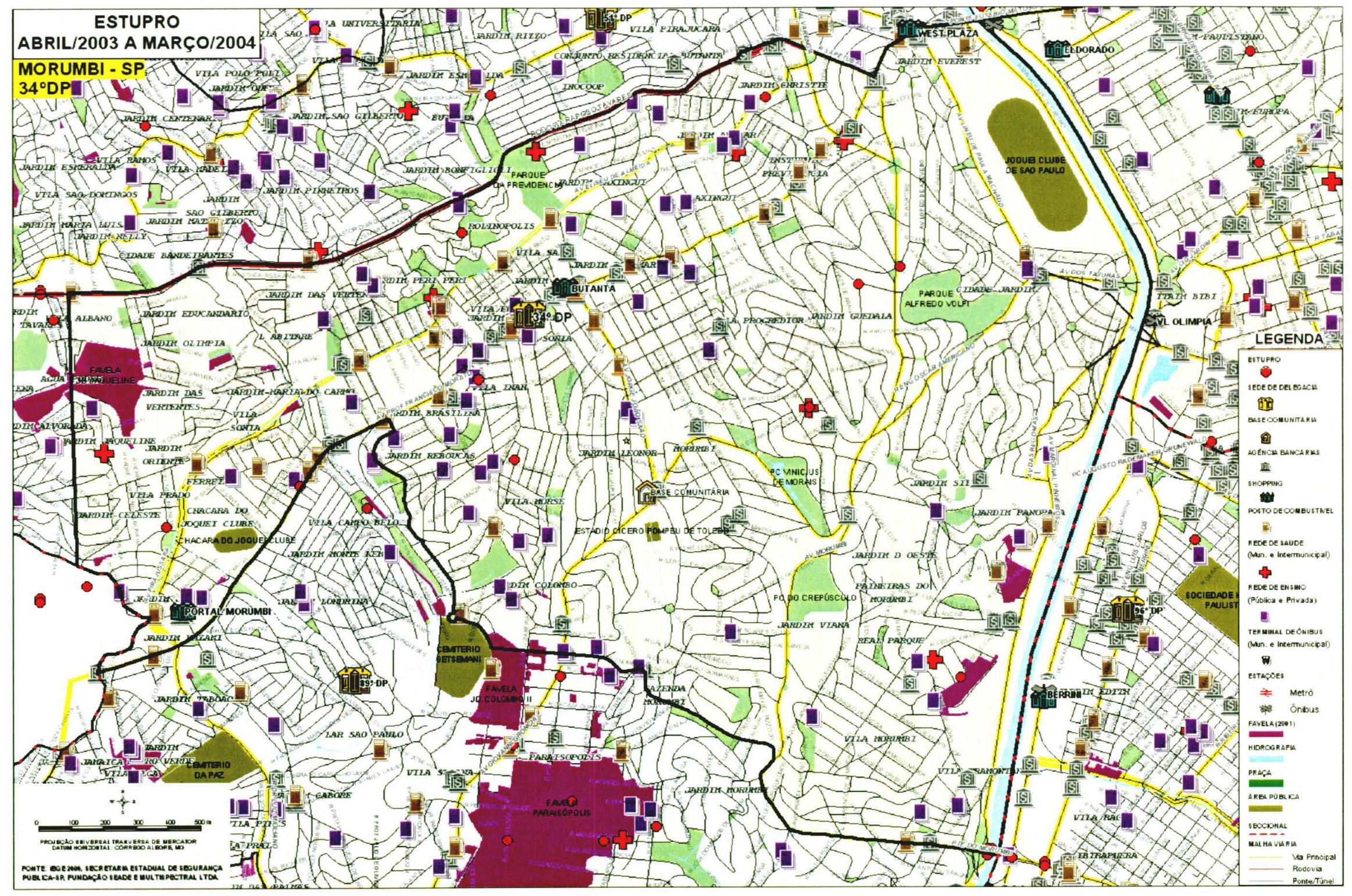

Figura 25 - Estupro - Morumbi 